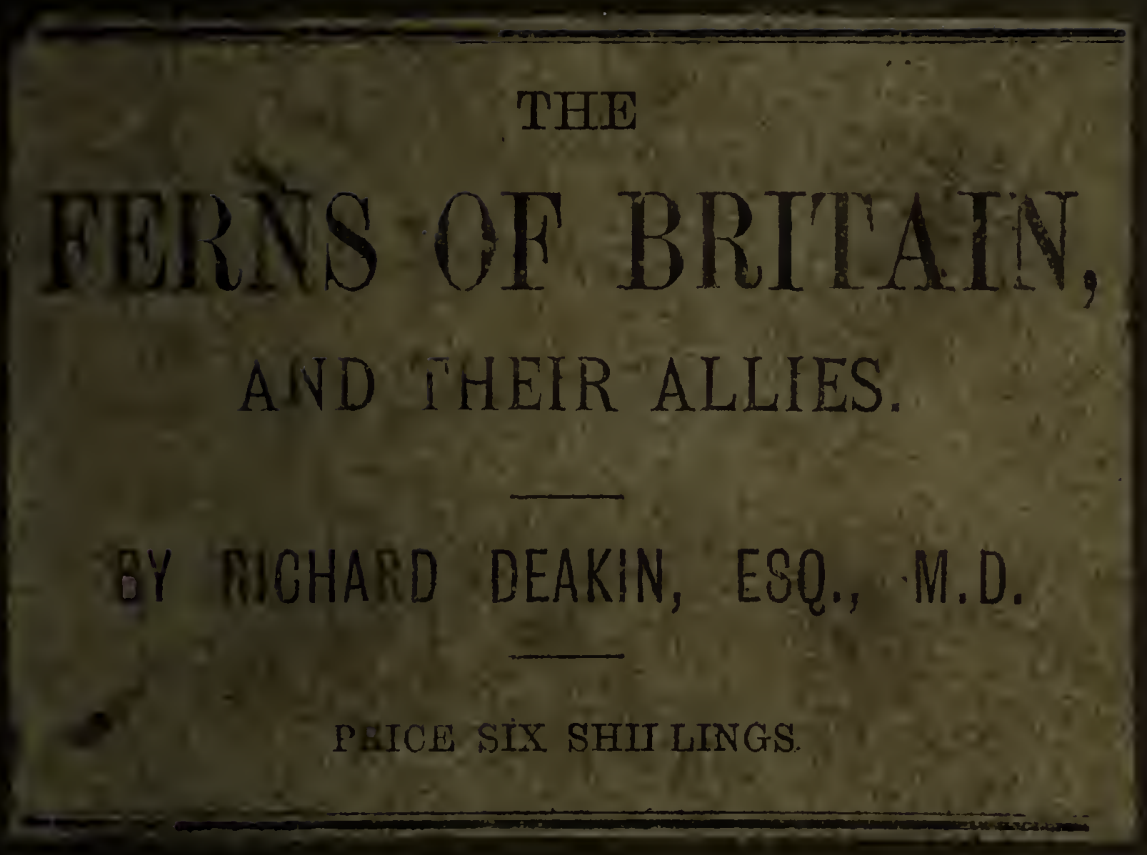




$$
19838 / 8
$$






\title{
FERNS OF BRITAIN,
}

\section{AND THEIR ALLIES;}

\author{
COMPRISING
}

EQUISETACEA，FILICACEÆ,

LYCOPODIACE $Æ$ \& MARSILEACE $Æ$,

FORMING THE FOURTH VOLUME OF

\section{FLORIGRAPHIA BRITANNICA.}

BY RICHARD DEAKIN, M.D.

LONDON :

HAMILTON, ADAMS, \& CO.; R. GROOMBRIDGE \& SONS; RIDGE \& JACKSON, KING-STREET, SHEFFIELD,

MDCCCXLVIII. 



\title{
SYNOPSIS OF THE GENERA.
}

\author{
Class 24. Cryptogamia (part of).
}

(Stamens and Pistils not visible.)

Order I. Equisetacee.-Horse-tails.

Fructification a terminal spike composed of whorls and of scales. Scales peltate, angular on footstalks, on the under side of which are from four to seven involucres, which open longitudinally and contain numerous globose bodies, enfolded by four filaments, club-shaped at their extremity and highly hygrometrical. [Semi-aquatic plants, with jointed subterranean rhizoma and erect, fistulous, striated, leafless stems, in the cuticle of which silex is secreted; jointed, easily separated at each joint, and surrounded by a membraneous toothed sheath. Stem simple or with whorls of branches from the base of the articulations, composed chiefly of cellular substance, perforated with longitudinal cavities, and surrounded externally with hard woody tubes, which also radiate towards the centre. Stomate arranged longitudinally in the cuticle.」

\section{GENERA.}

1. Equisetum, [page 13.] The only one of the order.

\section{Order II. Filices.-Ferns.}

Fructification only of one kind upon the same species. C'apsules (thecx) semi-transparent cases, arising from the veins on the under side of the leaf or from the margins; in clusters 
of various shape, called sori, rarely spiked or recurved, naked or covered with an indusium or involucre, formed by a portiou of the cuticle being forced up like a membranous covering. The thece are either pedicellated, with the pedicel passing round them in the form of an elastic ring, or sessile, and without a ring. Seeds or sporules very numerous, minute, mostly triangular or ovate, and occupying, without order, the thecæ. [Perennial plants producing a rhizoma in the place of a stem, which creeps below the surface of the ground, or in some exotic species rises above and forms a trunk-like stem. Leaves or fronds coiled up (circinate) in vernation, and are entire or much divided.]

\section{GENERA.}

Filices exannulate. Thece two-valved, without an elastic ring.

Family 1. Ophioglossacez. Vernation straight and the stem hollow.

1. Ophioglossum, [page 33.」 Thece oblong, two-valved, arranged in a straight club-shaped spike, attached to an undivided frord.

2. Botrychiom, [page 34.] Theca globose, two-valved, arranged in clusters on the margin of a compressed branched spike.

Family 2. Osmundaces. Vernation circinate, and the stem solid, as in the Filices anunlatæ.

3. Osmunda, [page 36.] Thece terminating the frond in branched spike-like clusters.

Filices annulata. Thece furnished with an elastic ring, and by the contraction of which the thin membranous sides are torn and the contained sporules scattered.

Section 1. Thece attached in clusters (sori) to the back of the frond.

Famidy 3. Polypodiaces. Thece in circular clusters (sori) without indusium.

4. Polypo'dium, [page 37.] Sori circular clusters. Indusium wanting. Fronds flat, the lateral veins not anastomozing. 
5. Woodsia, [page 45.] Sori circular, loose clusters, scattered. Indusium cut into numerous mostly capillary segments. Fronds flat, the lateral veins not anastomozing.

6. Allo'sorus, [page 47.] Sori circular clusters, becoming confluent and concealed by the revolute margin of the frond; the lateral veins not anastomozing.

Family 4. Adiantacex. Thece in linear or oblong clusters (sori), covered by a marginal or sub.marginal elongated portion of the frond on its superior cuticle in the form of an indusium.

7. Adian'tum, [page 49] Sori oblong or ruundish, covered by a portion of the frond reflexed, and a prolonged portion of its membranous margin forming an indusium, opening interiorly.

8. Loma'ria, [page 51.] Sori a continuous line on each side of the mid-rib, covered by a continuous indusium, the lateral veins not extending beyond the indusium.

9. Pteris, [page 52.] Sori continuous leanear, marginal, covered by a continuous marginal indusium.

Family 5. Aspleniacex. Thece in elongate clusters; sori covered by an indusium.

10. Asplenium, [page 57.] Suri oblong or linear. Indusium of the same shape, arising from the lateral veins, and opening on one side longitudinally towards the mid-rib.

11. Scolopendrium, (page 78.] Sori linear, transverse on lateral veins, always double. Indusium appearing single from both opening on the inner edge and attached on the outer.

12. Ceterach, [page 81.] Sori oblong or linear, clusters, scattered. Indusium obsolete, lateral veins anastomozing.

Family 6." Aspidiacee. Theca in circular clusters (sori) covered by an indusium.

13. Cystor'teris, [page 84.] Sori roundish clusters. Indusium inserted by a broad base, with the thece, to 
the frond, and containing the thece like a cup; its free margin ragged.

14. Polystichrum, [page 89.] Sori roundish clusters, scattered. Indusium orbicular or nearly so, attached by the centre only.

15. LastraA, [page 96.] Sori roundish clusters, scattered Indusium reniform.

Sectron 2. Theca attached in a receptacle situated on the margin of the frond.

Family 7. Hymenophyllaces, (as the section).

16 Trichomanes, [page 119.] Thece within a marginal cylindrical or suburceolate monophyllus receptacle which is of the same texture as the frond, opening above, and furnished with an exserted bristle-like appendage.

17. Hymenophylum, [page 122.] Theca within, a marginal two-valved receptacle. which is of the same texture as the frond, opening above; not furuished with a bristlelike appendage.

\section{SUB-ORDER I.}

\section{LyCOPODIACEA.—Club-moss.}

Stem solid vascular. Fructifications sessile in the axis of the leaves or bracteas. Thece bursting by distinct valves, and containing minute powdery matter or sporules, marked at the apex with three minute radiating lines.

1. Lycopodium, [page 125.] Thece one celled, two-valved, containing a fine powdery matter; and others, three. valved, containing a few large sporules.-Herbaceous plants, dry and rigid, with undivided scale-like leaves, imbricating the stem and branches.

\section{SUB-ORDER II.}

Ma Rsile ace - Pepperworts.

Creeping Plants. Fructifications inclosed in leathery involucres that are near the root of the plint. Thece or conceptacles 
of two kinds-one consisting uf membraneous sacs, muist and tumid, containing germinating sporules; the others, nembranous sacs, containing a gelatinous matter and numerous powdery grains.

1. Isoetes, [page 133.] Involucres formed by the dilated base of the leaves and enveloping the Thece, sone containing large and others numerous granular sporules. Sporules both rough and angular.

2. Pilularia, [page 135.] Thece naked axillary, containing in its upper upper part sessile corpuscles, which emit a yellow pollen or dust; and below these are other sessile bodies, which become single grained fruit. 



\title{
FLORIGRAPHIA BRITANNICA.
}

\section{CLASS XXIV.}

\author{
CRYPTOGAMTA (part of.)
}

The Equisetums, or the Horse-tail plants, are very remarkable, and seem to stand apart from near alliance with the other vegetable tribes. They are usually arranged with or next in order to the Ferns ; but their affinity to them is by no means obrious. Lindley remarks that " in the arrangement and appearance of their reproductive organs they have a striking resemblance to Zamia, and in general aspect to Casaurina. T'heir germination is that of cellular plants, and approaches nearly to Mosses. Upon the whole, they must be considered an exceedingly anomalous tribe, approaching Coniferæ, through Cycadaceæ, more closely than anything else."

The true stems are creeping, underground, as in the more humble form of ferns, called rhizoma; they are jointed, as are the upper stems or branches, but beneath the surface of the ground or water they put out from the joints whorls of radicles, which are more or less branched and slender, while from the upper joints arise simple or divided branches, jointed, but without any leafy expansion. The whole are fistulous, with solid joints or nodi at intervals, where they are separable, and surrounded with a membranous toothed sheath. The stem is either simple or branched at the base of the joints, and is more or less deeply striated or ribbed, silicious particles being 
secreted in the cuticle, and alternating with the ribs: the cylinder of the stem is perforated longitudinally with fistular cavities, but its general substance consists of cellular matter more or less elongated, and mixed with bundles of ringed vessels, which are connected with those cavities; the ribs are hardened woody tubers, and the stomata are arranged in longitudinal lines on the cuticle. The parts of fructification are collected into a spike-like form, and terminate the stem or branches; they consist of closely arranged whorls of peltate scales, each scale bearing on its lower surface an assemblage of cases of theca, which burst longitudinally, and contain granular bodies of a green colour, each have four elastic filaments coiled around it. These filaments are thickened or club-shaped at the free end; and intermixed with them are discovered also within the thecæ smaller simple granular bodies, which by some are considered the pollen. We have given figures of these extremely beautiful microscopic organs, in their various stages of developement, from a plate illustrative of "The Reproductive Organs of Equisetum, by Mr. Joseph Henderson" published in the 18 th vol. of the Transactions of the Linnæan Society, London Fig. $a$ is a single sporule, enveloped in its own integument, having at each end minute appendages, which are supposed to be the points of its con-
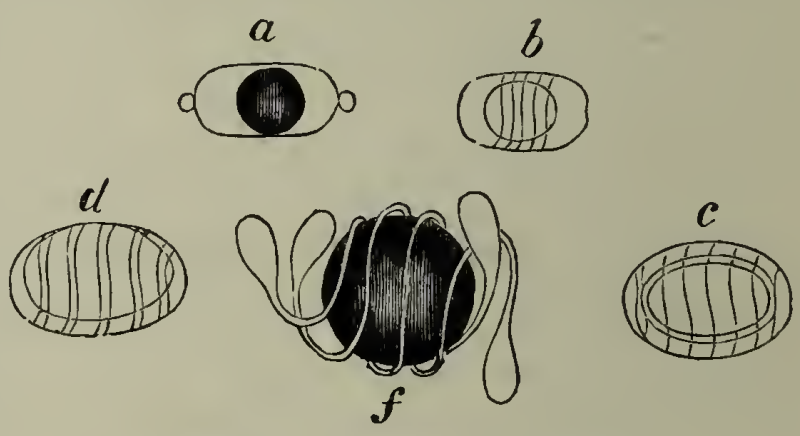

nection when in the theca at an earlier stage ; fig. $b$ shows the scarcely visible commencement of the sutures in the integument, and which are seen more advanced in fig. $c$, and fully formed in fig. $d$, where it is seen about to separate into its four filaments; fig. $e$ is an end view of the same, showing the dilated portion; fig. $f$ is a sporule fully formed, with the filaments unrolling themselves; fig. $g$, the sporule with its outer tunic, as it is seen after immersion in dilute tincture of iodine.

The germination of these sporules has been a favourite subject of investigation with many persons, and some have supposed them to be true seeds, and to have a cotyledon or seed lobe, as in monocotyledonous plants. We have given the following illustrations of the 
derelopement of the sporules from Vaucher, who has paid much attention to the subject, and from which it would seem that their developement is much more like that of mosses than of monocoty. ledonous seeds. Fig. $a$ is a sporule beginning to enlarge; $b$, it is more pointing into a root; $c$, the root is formed, and the upper part more swollen; $d$, the same still more advanced; $e$, the same with its first whorl of branches; $f$, with the stem beginning to be formed; $g$, the same the natural size. Agardh, in describing the progress of this germination, says - "from three to fourteen days after they are sown, they send down a filiform hyaline, somewhat clavate, simple root, and

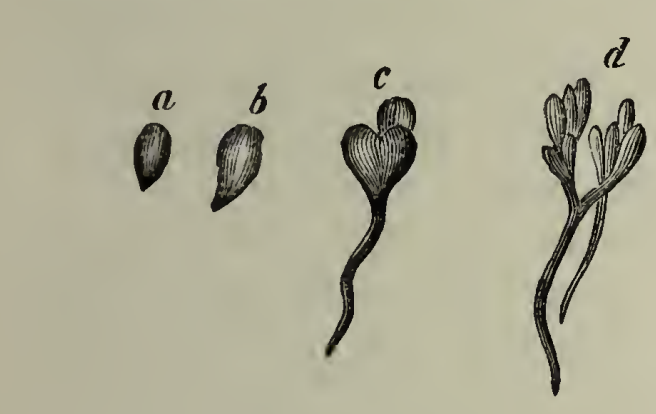

protrude a confer-

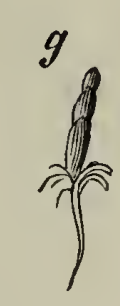

void cylindrical obtuse articulated torulous thread, either two lobed (in E. pratense) at the apex, or simple (in E. palustre). Some days after,

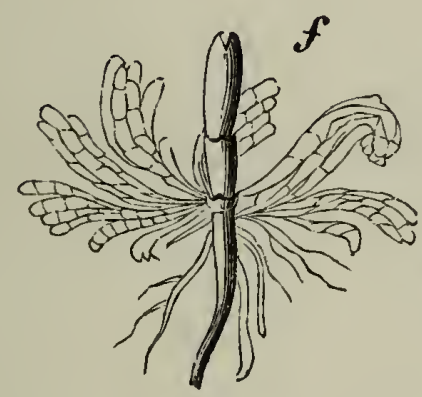
several branches grow out, and are agglutinated to gether, forming a body resembling a bundle of confervoid threads, each

of which pushes out its own root." And Bischoff (in Nor. Act. Acad. N. Cur. 14. t. 44.) says, that he finds the confervoid threads or numerous processes of cellular developement go on growing and combining until a considerable cellular mass is formed; then this mode of developement ceases, and a young bud is created, which springs up in the form of the stem of the Equisetum, at once completely organised, with its air-cells, its central cavity, and its sheaths, the first of which is formed before the elongation of the stem out of the original cellular matter.

The Equisetaceæ, though a small tribe, and consisting of but one genus, are distributed in all parts of the globe, from the Equator to the Polar circles; but they are most numerous in the tropical regions, and vary greatly in magnitude, according to the temperature where they grow. The $\boldsymbol{E}$. scirpioides is a very minute plant, found 
amongst moss at the root of trees in North America; and E. reptans, equally small, is a native of the bare mountain regions of Lapland; while our $E$. Telmateia grows four to eight feet high, but this even is minute compared with those majestic species which flourished at an earlier period of the globe, and are now only known in their fossil state, and which the laborious investigations of Brongniart, Hutton, Lindley, and others, have brought into notice. They occur not only in the coal formations, but in the marls of the Lias and Oolite strata. It is an extremely interesting subject of inquiry how those masses of vegetable matter which form the coal strata should have been col. lected together, and the causes which were in operation not only for their growth and developement, but which annihilated them; for none of the fossil forms either of the Equisetums or Ferns, can be recognised amongst the now existing species.

The Equisetums are remarkable for the quantity of siliceous particles secreted in the cuticle, which gives them a rough feeling to the touch. Dr. Brewster subjected a portion of the cuticle to the analysis of polarized light under a high magnifying power, by which means he detected a most beautiful arrangement of these flinty particles, which he states are distributed in two lines parallel to the axis of the stem, and that they extend over the whole surface of the cuticle, and that " the greater number of the particles form simple straight lines, but the rest are grouped into oval forms, connected together like the jewels of a necklace by a chain of particles, forming a sort of curvilineal quadrangle, these rows of oval combinations being arranged in pairs. Many of these particles which form the straight lines do not exceed the five-hundredth part of an inch in diameter." Dr. Brewster also observed the remarkable fact that each particle has a regular axis of double refraction. In the straw and chaff of wheat, barley, oats, and rye, he noticed analagous phenomena, but the particles were arranged in a different manner, and displayed figures of singular beauty. From these data the learned Doctor concludes "that the crystalline portions of silex and other earths which are formed in vegetable fibres, are not foreign substances of accidental occurrence; but are integral parts of the plant itself, and probably perform some important function in the process of vegetable life."-Grevill Fl. Edineus, p. 214. So great has the quantity of silex thus deposited been found in the cuticle of $E$. hyemale, that $\mathrm{Mr}$. Sweight has been enabled to decompose and remove the regetable matter without injuring the silicious skeleton form of the stem. 


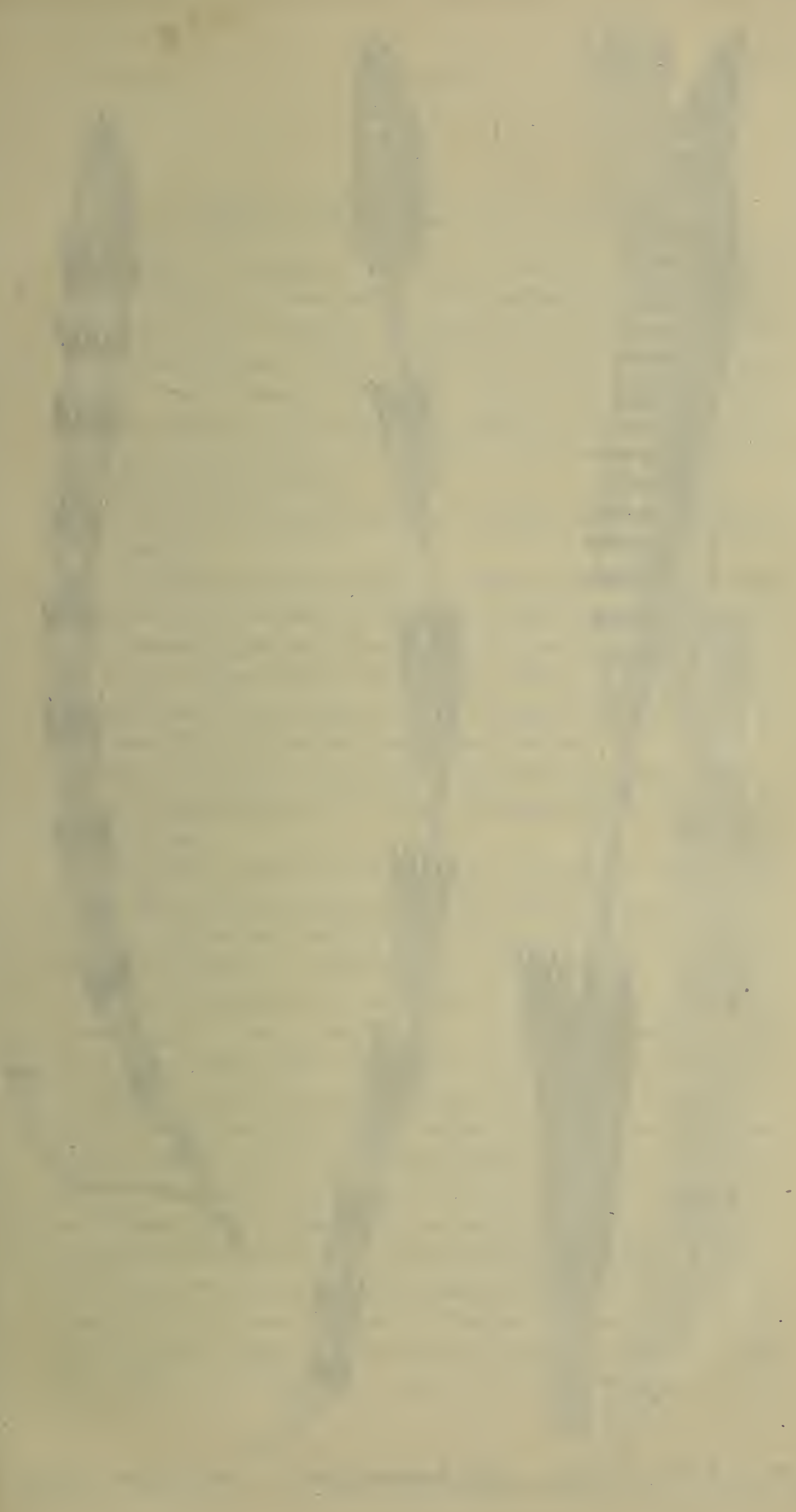




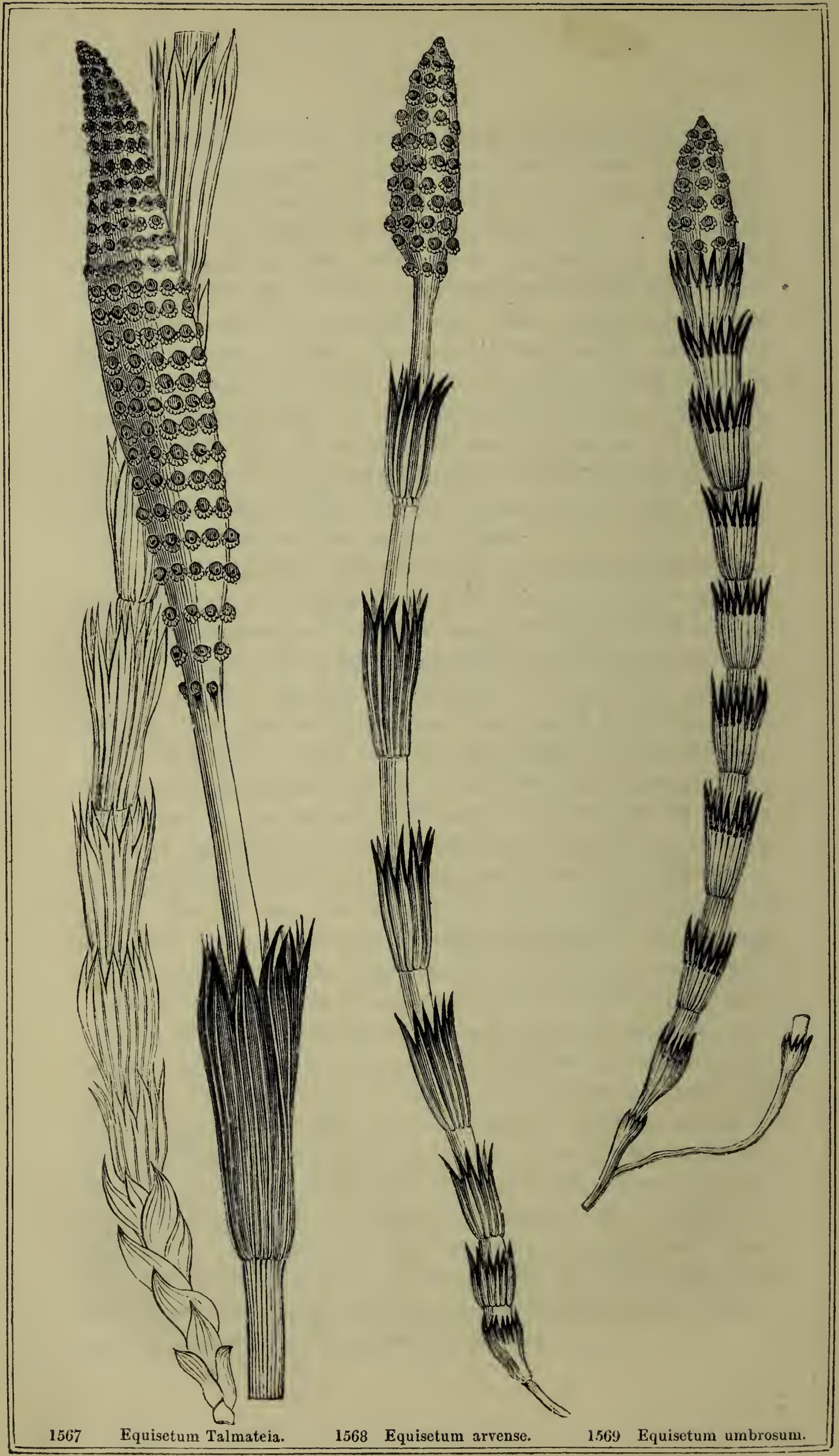


GENUS. EQUISETUM.-Linn. Horsetail.

Gen. Char. Fructification terminal, in cone-like spikes or catkins consisting of peltate scales, on the underside of which are from four to seven involucres, which open longitudinally, and contain numerous globose bodies, enfolced by four filaments, club-shaped at their extremity, and highly hygrometrical.-[Rigid leafless branched plants, uith striated fistulous stems and branches, in the cuticle of which silex is secreted, numerously jointed, with sheathing toothed articulations.]

1. Fertile stems simple, succulent; barren stems with whorled branches.

1. E. Telmateia, Ehrh. (Fig. 1567.) Great mud Horsetail. Fertile stem simple, terminating in an obtuse spike, the sheaths numerous, large, funnel-shaped, with about twenty ribs, each rib terminating in as many subulate teeth; sterile stems smooth, bearing numerous whorls of nearly erect simple unequally octagonal rough branches, the alternate furrow widest, their sheaths four toothed.

Newman's British Ferns, p. 67.-E. fuviatile.-English Botany, t. 2022. -English Flora, vol. iv. p. 324.-Hooker, British Flora, ed. 4. vol. i. p. 393.

Root slender, fibrous, in whorls from the joints, the underground stems long, deep black, spreading. The stems are of three kinds. 1. simple, unbranched, bearing only a spike; 2 . bearing spike and whorls of branches; 3 . bearing whorls of branches only. The fertile stem is erect, simple, from nine to fifteen inches long, round, smooth, succulen $\hat{\imath}$, pale brown, more or less numerously jointed, and from each joint arises a large sheath, loose, funnel shaped, especially the upper ones; the lower half of the sheath is a pale greenish brown, the upper part brown, membranous, striated with the numerous green ribs, which terminate in the slender subulate teeth, the catkin is from two to three inches long, and from one to one and half inches in circumference in its thickest part, the scales are very numerous, and arranged in whorls, the lower ones usually indistinct separate whorls, the rest closely crowded. Barren stems erect, often attaining the height of seven feet, and nearly two inches in circumference, though. the usual size is about five feet, and an inch in circumference about its middle, but thicker below, and very slender at the top, quite 
smooth, white, or pale green, but the lower joints become dark brown, a]most black ; from each joint arises a sheath, which is about half an inch long, the lower half is a pale green, the upper is dark brown, and divided into teeth, the former is impressed with about thirty furrows, the intervening spaces forming a flattish rib, or shallow channel, which is prolonged into a setiform tooth, the elevated margins uniting together, and forming the dark mid-rib of the tooth, its margins are dilated into a thin membrane, often shaggy, pale brown, and frequently united together, from the base of the sheath, except a few at the bottom of the stem, and several crowded together; from the base of the sheath arise whorls of slender branches, each branch arising from the base of the rib of the sheath, the branches of the lower whorls are short and recurved, but those of the upper are often nine and erect; the branches are for the most part simple, but occasionally it is branched at the second joint, the colour of the branches is a delicate cheerful green, each branch is slender, and composed of from six to ten jointed pieces, of an unequally octagonal form, composed of eight elevated ribs, rough, with silicious particles, the alter nate intervening furrows being as wide again as the other; the sheaths at the joints are short, funnel-shaped, four toothed, each tooth being formed by a prolongation of the approximating ribs of the branch, and uniting at the apex of the tooth, the sides are pale, thin, membranous, occasionally the branches have ten ribs and furrows, and then the sheaths have five teeth. Besides the barren and fertile stems described, there is not unfrequently found also a third kind, bearing both branches and a spike of fructification, but the whole plant is smaller, and appears to be in a starved state: indeed it seems to be the opinion of several Botanists that this peculiarity is caused from the want of a sufficient supply of moisture.

Habitat.-Sand banks and dry ditches; not unfrequent.

Perennial; in fruit in April.

This is the largest and most handsome of our species of Equiseta. It is much smoother than the $E$. hyemale, and is not like it used for any household purposes. It is affirmed by Linnæus that the reindeer, which refuses to eat hay, will eat this plant, and that it is cut as fodder for kine, but that it is not acceptable to horses. According to Haller, this plant was eaten by the common people among the Romans; but as this, as well as several other species, form sub. terrancan tubers, something like potatoes, and abound in starchy matter, it is not improbable to be the Chara, mentioned by Cæsar 


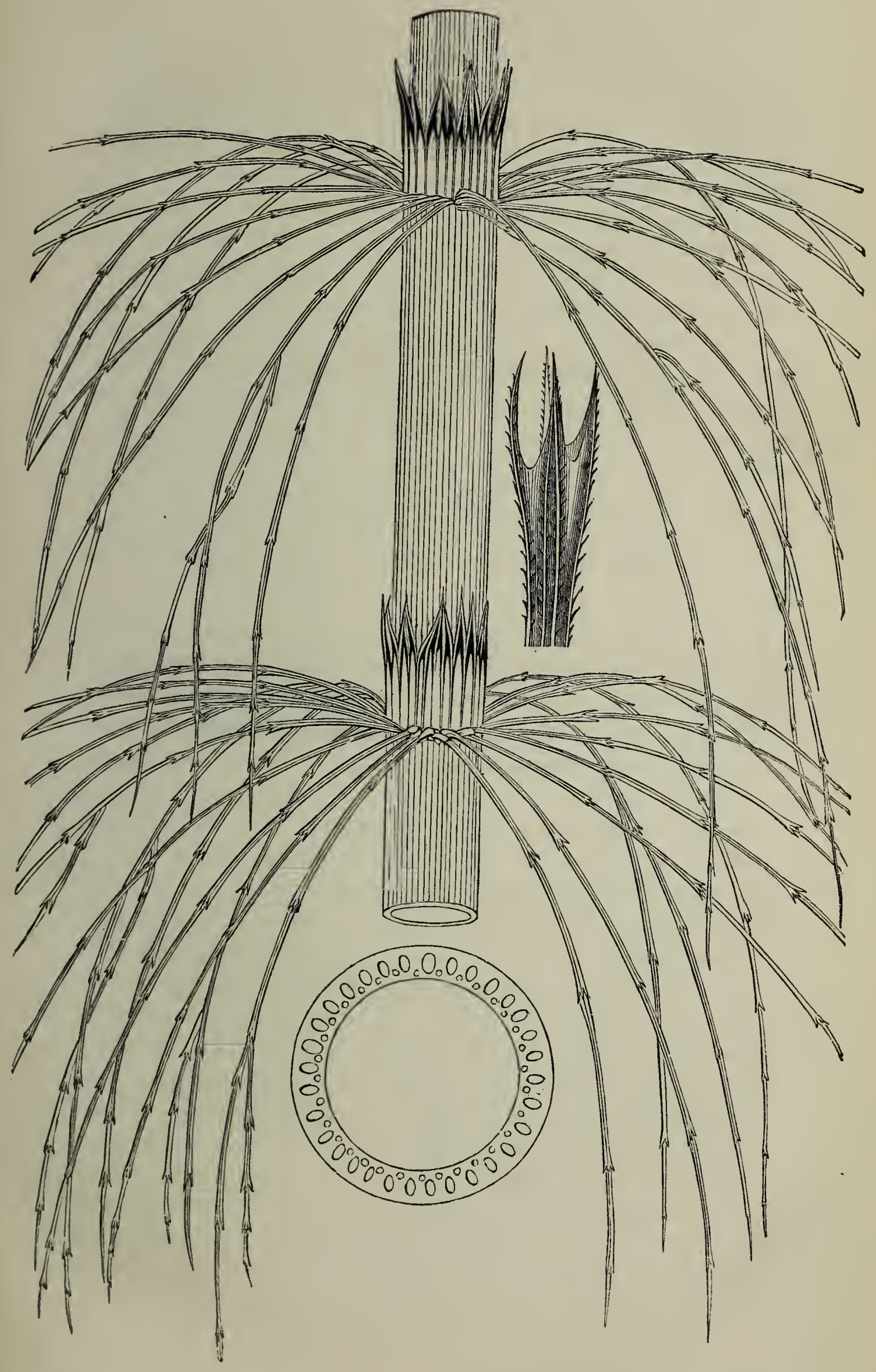


(De Bello Curle, 1. 3. c. 40.) 'The r'oots of these Chara, it is stated, were eaten either mixed with milk, or made into a kind of bread. During the civil war they at one time very greatly relieved Cæsar's army, which he states was in spain, and was much straightened in the supplies of ordinary provisions; and at the time when Pompey's soldiers exultingly spoke of the famine, those of Cæsar, to show them the mistake of their conjectures, frequently threw among the ranks loaves of Chara bread. The illustrations we have given of this Equisetum are the natural size of an ordinary plant, but the section of the stem and the sheath of the branch are magnified to show more clearly their structure. Few plants are more gracefully elegant in their port than this when growing in its native situation, and free from the shade and drip of trees. It is the largest and most stately of any of the now known existing species, though but a dwarf compared with those found in a fossil state, and passed for ever as living plants from our earth. It is not unfrequent in various parts of the Continent in sandy places; and we have specimens from the Island of Madeira, which do not differ in any respect from those found in a more northern climate.

2. E. arven'se, Linn. (Fig. 1569.) Corn field Horsetail. Fertile stem simple, terminating in an obtuse spike, the sheaths loose, funnelshaped, with about ten ribs, each rib terminating in as many lanceolate teeth; sterile stems smooth, bearing numerous sheaths, the upper ones furnished with whorls of quadrangular branches, their sheaths four toothed, and rough.

English Botany, 2020.- English Flora, vol. iv p. 324.-Hooker, British Flora, ed. 4. vol. i. p. 393.-Newman's Ferns, p. 77.

Roots whorled, fibres at intervals on the long creeping branched underground stems. The fertile and barren stems are distinct from the same rhizoma, the fertile stem is erect, about ten inches high, round, smooth, succulent, a pale brown colour, without the appearance of silicious particles, the joints are about eight, each internode upwards being longer than the one below it, the sheaths large, funnel. shaped, pale yellow colour at the base, dark brown upwards, about ten ribbed, each rib terminating in a lanceolate pointed tooth, the furrows between the ribs are pale, and form a pale membranous margin to each tooth. The spike is about an inch and a quarter long, somewhat tapered upwards, the point obtuse, of a pale delicate brown or rosy red hue, the whorls of scales very various in number, the lower one often distant from the others. The barren stem, which is 


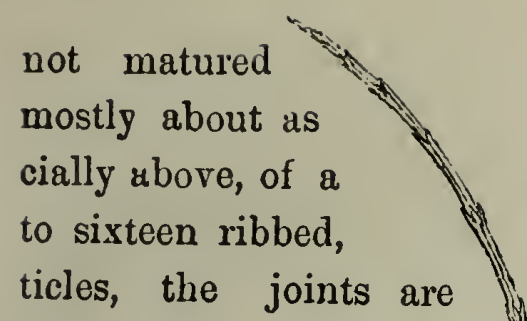

until the perfect one has withered, is long again, nearly erect, slender, espeglaucous green colour, from eight studded over with minute silicious par. about twenty, the lower ones at the

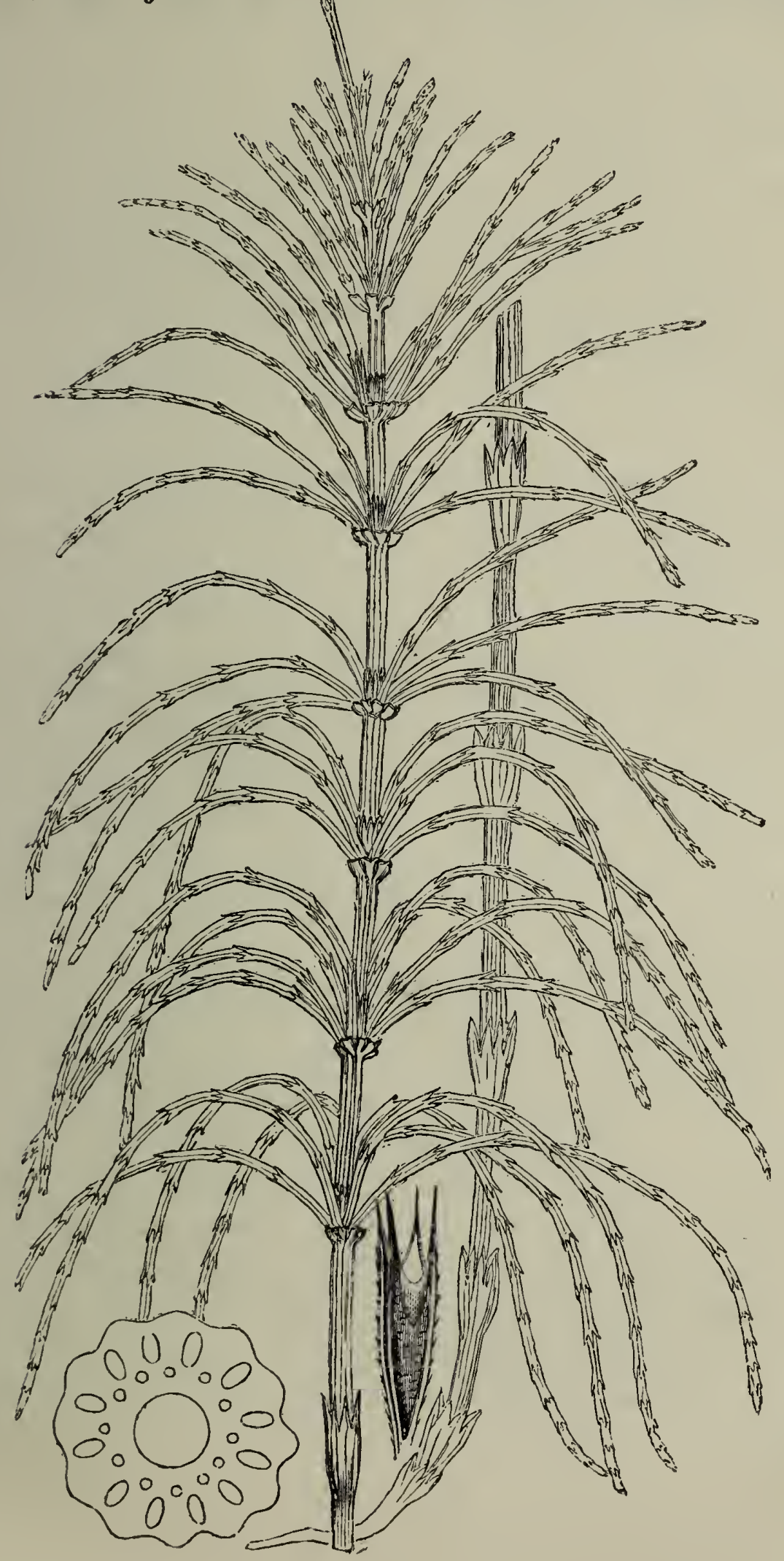


root crowded, five or six above, these are distant, and furnished with sheaths only; the six or eight above these bear whorls of simple branches, and the upper ones are simple, similar to those of the branches. The sheaths of the stem are short, tubular, with the same number of ribs as the stem, and a corresponding number of teeth, which are lanceolate, brown at the points, and mostly with a mem. branous margin. The whorls of branches arise immediately below the sheaths, from the furrows of the stem, and are the same number; each branch is furnished at its base with a pale brown short toothed membranous sheath, is from four to eight inches long, simple or branched, spreading, four angled, with a row of silicious particles on each angle, ten to twelve jointed, each joint furnished with a close short sheath, terminating in four long acute colourless teeth, with pale membranous margins, the mid-rib terminating in a sharp point.

Habitat.-Corn fields and waste places; very common.

Perennial; in fruit in April.

This is the most commonly distributed and the most abundant of our native species of Equisetum, and, indeed, it is in many places a great nuisance to the farmer in his corn fields, as well as to the gardener in his grounds, for the roots grow rapidly, and spread extensively, and are with difficulty extirpated. As far as we know, it is applied to no useful or economical purpose, and is not eaten by cattle at any time from choice, but from necessity; it grows very quickly, and speedily comes to perfection; but the barren stems, so different from the fertile and more succulent ones, continue longer, and seem in the economy of nature to be for the purpose of purifying the proper juices of the plant, and strengthening the roots impoverished by the fruit-bearing stems.

The illustrations are drawn from ordinary grown plants, and are of the natural size, except the section of the barren stem, and the sheath of the branches given in page 17 , which are magnified, to show more clearly their structure.

3. E. umbro'sum, Willd. (Fig. 1569.) Shady Horsetail. Fertile stem simple, often becoming branched, the sheaths large, loose, funnel-shaped, pale, with from ten to fifteen slender awl-shaped dark brown teeth, the spike ovate, pale brown, sessile, or nearly so ; sterile stem rough, its sheaths much smaller, the upper ones furnished with whorls of simple branches, their sheaths short, with three ovate acute teeth. 
Newman's Ferns. p. 63.-E. Drummondii._English Botany Suppl. t. 2777.-Hooker, British Flora, ed. 4. vol. i. p. 393.

Roots slender whorled brancies, at intervals on the long creeping black underground stems. The fertile and barren stems are usually quite distinct, the former bearing fruit only, and the latter only branches, but sometimes the fertile stem puts out branches also. The fertile stems are about six inches high, of a pale yellowish green colour, slightly striated, numerously jointed, and the internodi almost entirely covered with the large loose funnel-shaped sheaths, nearly white, the teeth are brown, awl-shaped, with a thin membranous margin, and a mid-rib elongated into the point; they are mostly about twenty in number, the same as the ribs of the sheath. The spike is ovate, sessile, becoming elevated on a short footstalk, of a pale brown colour, the scales are almost hexagonal in form, with a central depression, and about forty in number. Barren stem commonly about eighteen inches high, rough, with silicious points, erect, and about twenty jointed, but the joints are much longer, and the sheaths much smaller than those of the fertile stem, the lower four or five sheaths are naked, but the rest are furnished at the base with whorls of from ten to sixteen branches, simple, at first drooping, becoming more erect ; they are about eight jointed, triangular, and rough, with silicious points, the sheaths are short, terminating in three ovate acute teeth, brownish at the point, pale and membranous on the margin, and the mid-rib terminating before reaching the point. Those stems bearing both a spike and branehes are intermediate between the exclusively barren and fertile stems, the sheaths are smaller than those of the fertile stem, but larger than those of the barren, the whorls are fewer in number, and with a less number of branches than those of the barren stems, and the spike is not so large.

Habitat.-Barks of the Isla and Esk, Forfarshire, Mr. T. Drummond; near Forfar, by the Caledonian Canal, Dr. Graham; and various parts of Scotland. Near Belfast, Ireland.-Mr. Harvey In a moist wood near Mereclough, by Manchester. Mr. Wor,dward's herbarium.-Newman. Near Winch Bridge, Teesdale.-Mr. Hardy.

Perennial ; in fruit in April.

This beautiful species of Equisetum, it will be seen from the illus. trations, (which are drawn of the natural size of the plant), is very distinct in its characters from the other described species, and though at present considered a rare plant, will, we doubt not, be found to be more common, as greater attention is directed by Botanists to this 
EQUISETUM.

[CLASS XXIV.

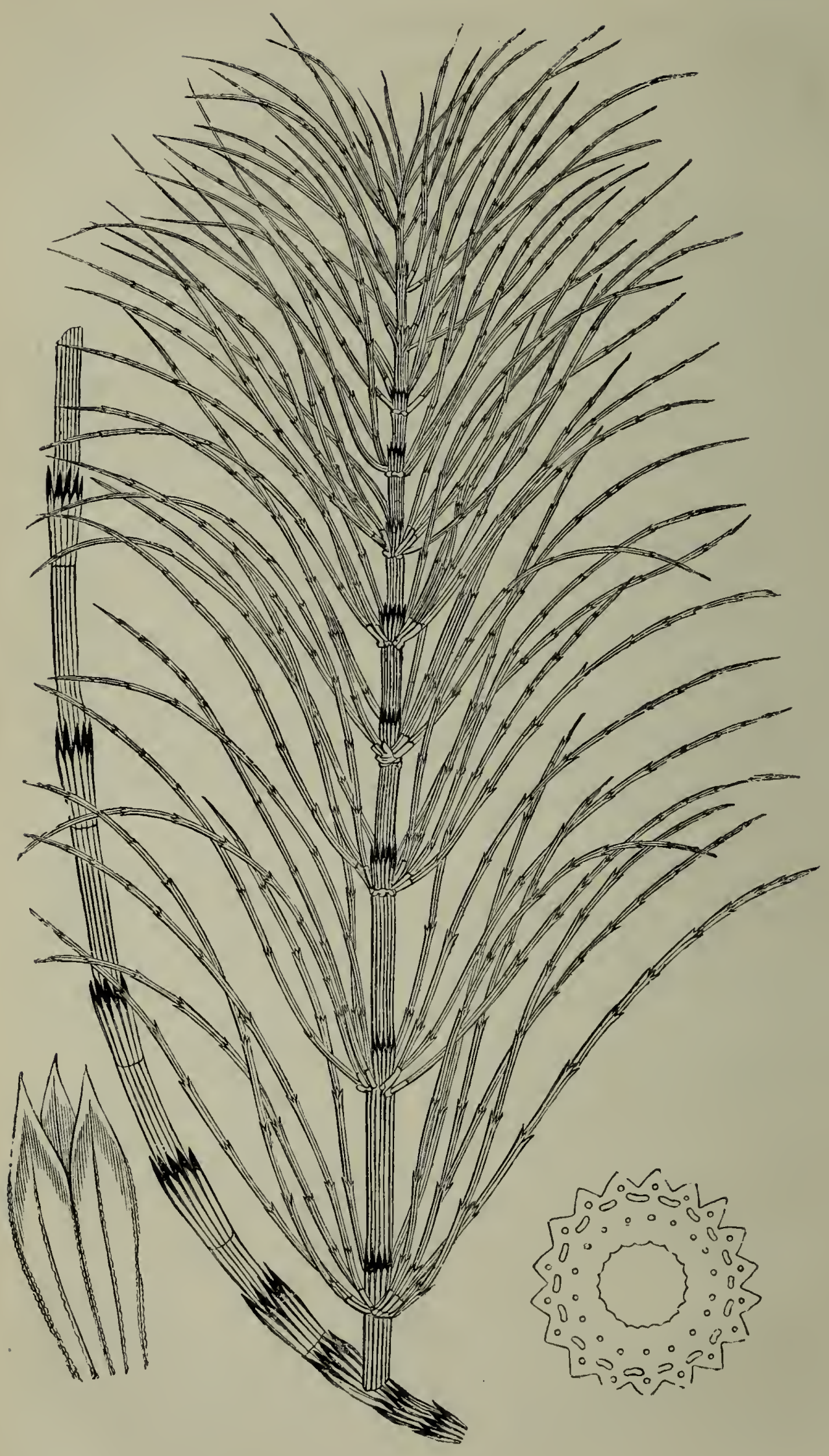


genus of plants. It is by no means rare in various parts of the Continent. Its habit is very different from the other species, and its very distinctive marked characters of difference are in the section of the stem and the sheaths of the branches of the barren stem, as shewn in page 20 , as well as those of the fertile one.

2. Fertile stems with whorls of short branches, barren stems with whorls of long branches.

4. E. sylvat'icum, Linn. (Fig. 1570.) Wood Horsetail.-Fertile stems smooth, becoming branched, as the terminal obtuse spike is developed, the sheaths large, loose, membranous, lobed; sterile stems rough, sheaths much smaller, the upper ones furnished with dense whorls of slender drooping triangular branches, their sheaths short, with three slender awl-shaped teeth.

Fnglish Botany, t. 1874.-English Flora, vol. iv. p. 323.-Hooker, British Flora, ed. 4. vol. i. p. 393.-Newman's Ferns, p. 77.

Roots slender whorled branches, at intervals, on the long creeping black underground stems. The fertile and barren stems are both furnished with branches, and spring from the same rhizoma. The fertile stem arises from the ground quite naked and simple, but as the spike is perfected there issue from the base of the upper sheaths whorls of branches, which mostly put out from each joint short rigid branchlets; the stems are round, succulent, with about twelve stria, of a yellow sickly hue, smooth, or nearly so, the joints very various in number, crowded at the base, becoming more distant upwards; the sheaths large, loose, striated, with the same number of ribs as there are on the stem, the lower half pale green, the upper bright brown, and membranous, divided into several lobes. The spike is about an inch long, somewhat tapered upwards, and obtuse at the apex, its scales are dark russet brown, and about eighty in number. The barren stem, which makes its appearance at the same time as the fertile, is more slender, rougher, and its sheaths much smaller, the lower ones are naked, but the upper ones are furnished with a whorl of crowded branches, arising from the furrows of the stem, consequently the same number. The branches are slender, triangular, and roughish, with minute silicious points, and about twelve jointed, the first joint has often four angles, and slender intermediate ribs, the upper ones gradually become smaller and shorter, and from the lower joints of many of them arise two or three slender branchlets. The basal sheath is pale brown, membranous, the rest are short, pale, 


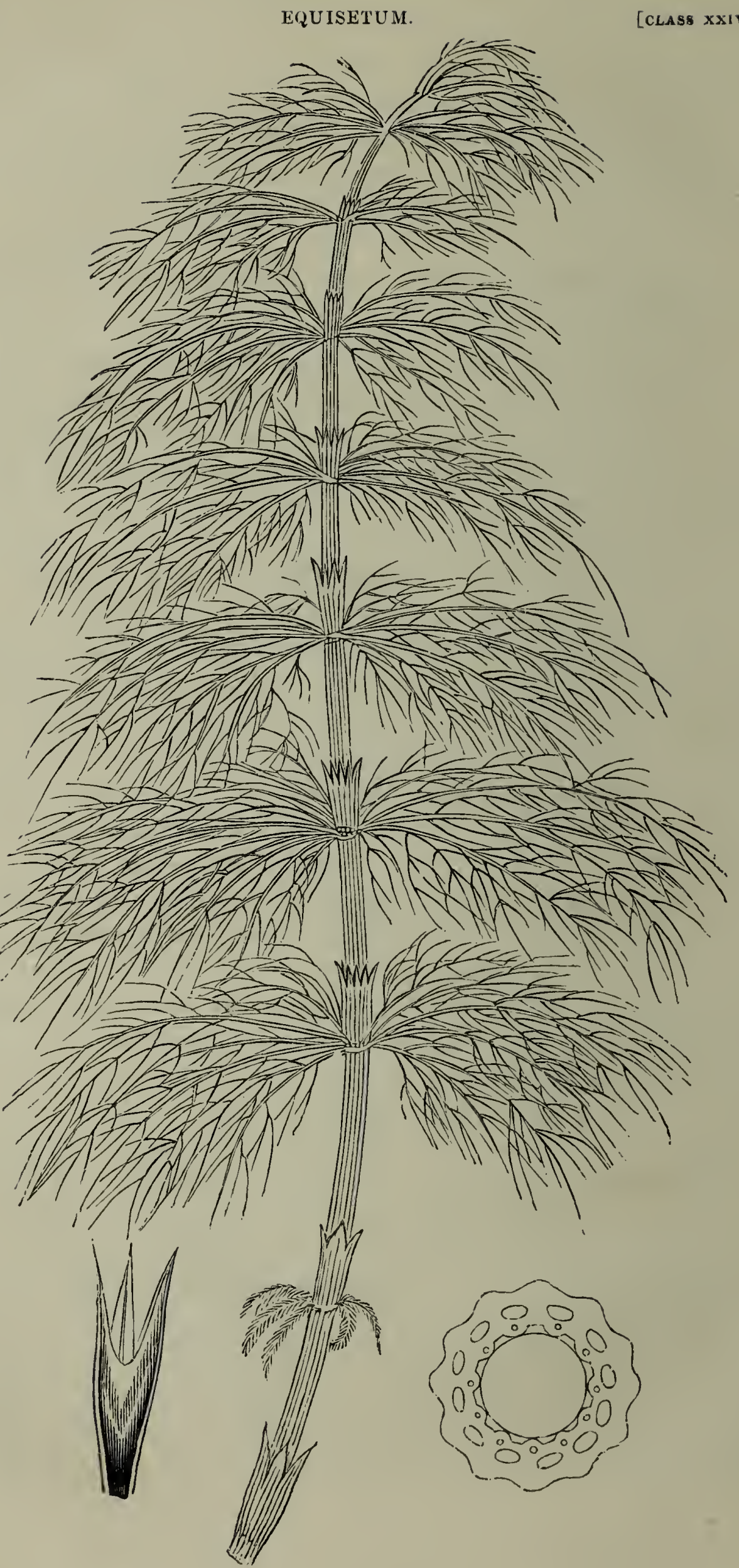


with three awl-shaped teeth, the mid-rib being a continuation of the angle of the branch, and is prolonged to the apex.

Habitat.-Moist woods, shady banks, and hedges ; frequent.

Perennial; in fruit in April and May.

This very elegant species of Equisetum is generally distributed, and so distinctive in its characters from all the other of our native plants, as not to be confounded with them. Our illustrations are drawn of the natural size of one of the ordinary plants, and from the magnified sheath, and section of the stem, given with the barren plant on the opposite page, it will be seen how beautiful and different it is in the arrangement of its parts from those of the other species.

\section{Fertile and barren stems similar.}

\section{$\S$ Stems branched.}

5. E. palus'tre, Linn. (Eig. 1571.) Marsh Horsetail. Fertile and barren stems similar, nearly smooth, with about eight deep furrows, branched, the sheaths slightly swollen upwards, with about eight sulcated ribs, terminating in lanceolate brown tipped teeth, with pale membranous margins, the branches simple, deeply five or six furrowed, their sheaths close, terminating in five or six teeth, similar to those of the stem.

English Botany, t. 2021.-English Flora, vol. iv. p. 325.-Hooker, British Flora, ed. 4. vol. i. p. 394.-Newman's Ferns, p. 43.

B. polystachion, Willd. Smaller, with the upper whorls of branches terminating in small compact spikes.

$\gamma \cdot$ alpinum, Hook. Much, smaller, with four or five angles and teeth, the sheaths to upper branches abortive.

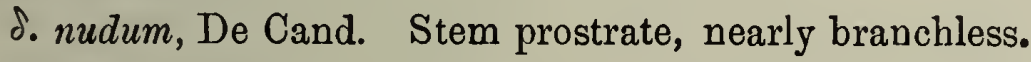

Roots slender whorled branches from the joints of the long branched black smooth and shining rhizoma. The stem is usually erect, about fifteen inches high, with about eight deep furrows and prominent ribs, slightly rough, with minute silicious particles; the joints are from ten to eighteen in number, the three or four at the base are crowded together, the rest are from an inch to an inch and half apart, the sheaths are loose around the stem, but nearly cylindrical, with as many ribs as there are on the stem, but towards the top it is more or less channeled, which channels, however, do not extend to the point or the base, the teeth are lanceolate, brown or black, with a pale membranous margin, the upper joints are furnished with whorls of simple erect or spreading branches, the same in number as the furrows 
of the stems from whence they arise, or fewer, they are four or five ribbed, and divided into from six to twelve joints, the basal sheath is short, almost black, and membranous, the rest are close, with the same number of ribs as the branch, sulcated, and terminating in pale brown lanceolate teeth, with white membranous margins, the branches are barren, or terminating in a spike. Sometimes the whole plant is

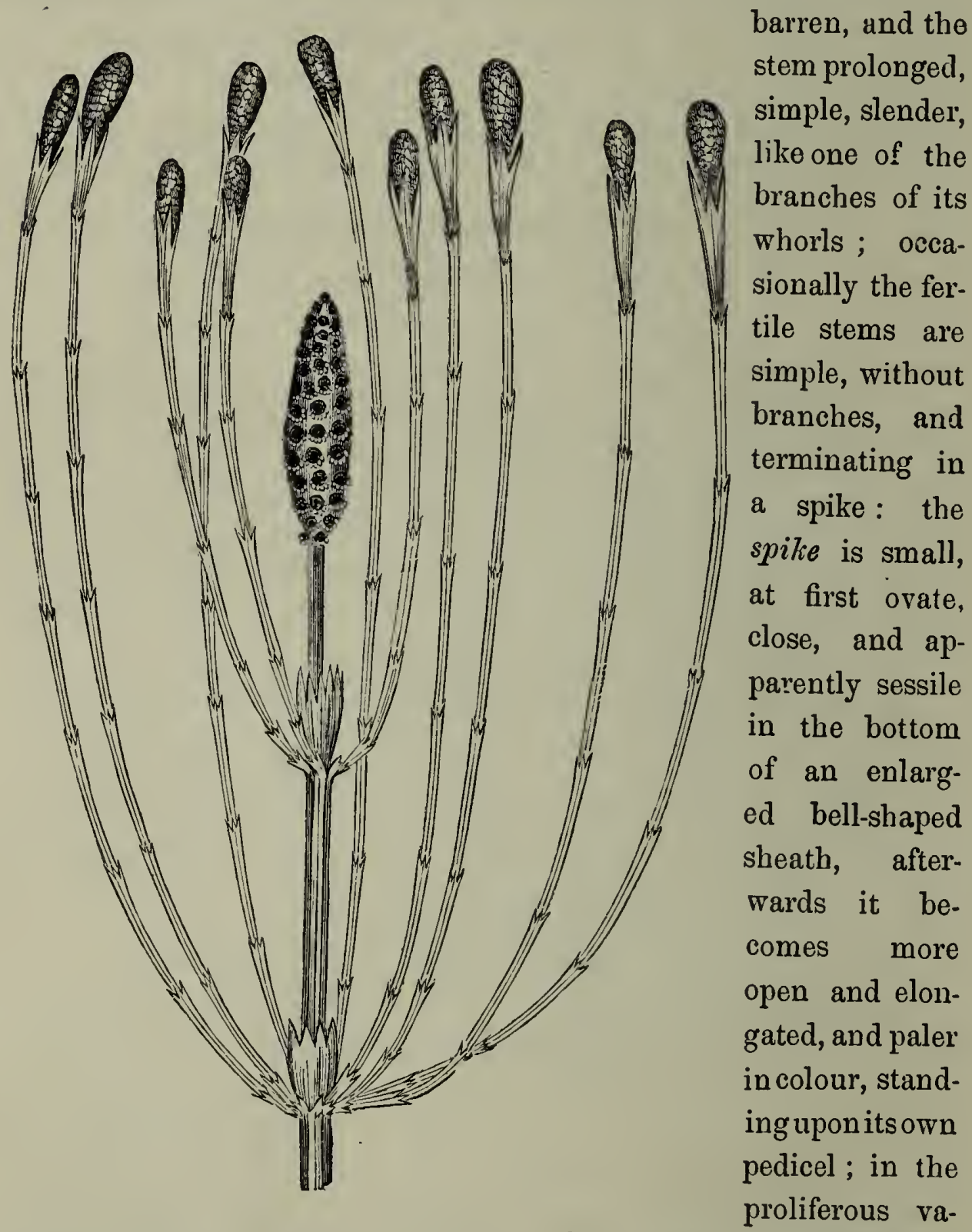
rieties, the spike terminating the stem, often is matured,- and withers away before those on its branches are perfected.

Habitat.-Boggy soil, not unfrequent. $\beta$. a rich loamy wet soil. $\gamma \cdot$ Boggy places near springs in the higher parts of the Breadalbane Mountains. \&. Dryer sandy situations.

Perennial; in fruit in June and July. 
This species is subjected to very great variations in its general characters. Our illustration (Fig. 157J) is an ordinary sized plant drawn of the natural size and proportion, and is the normal type of it; but one of the most distinctive variations to which it is liable is that which is called polystachion, of which we have given a drawing of the natural proportions, of the upper part of a specimen. (See plate, p. 24.) It is remarkable from the branches of the two upper whorls each terminating in a small black compact spike. The terminal spike in the specimen which we have drawn is larger than the others, but it is sometimes found that the spike terminating the stem is not larger than those of the branches, and occasionally it is perfected and decayed before the others are matured Another variety is found in high mountainous marshes, and is known by its stem and branches being only four angled, or at most five, and its sheaths with the same number of teeth; its branches are abortive, and is the variety alpinum, Hook. Another variety, which has received the appellation of nudum, is as small as the last, but is quite simple, without

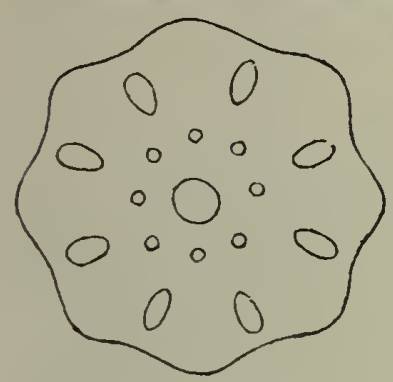
whorled branches, except very short ones at the base. From the transverse section of the stem of this species it will be seen how similar it is in its structure to that of E. arvensis, though in other respects quite different, and not to be confounded with it in distinguishing the species. It is a generally distributed plant in marshy districts, but has not, that we are aware of, been applied to any useful purpose: it is not apparently relished as food by any animals, and though this or some of its allied species appear to have been used by some of the old physicians as astringents, they are now totally out of use.

6. E. fluviatile, Linn. (Fig. 1572.) Water Horsetail. Fertile and barren stems similar, smooth, with about sixteen striæ, quite simple or branched, the sheaths short, pale and close below, more open above, with about sixteen black awl-shaped teeth, with a very narrow pale membranous margin, the branches rigid, simple, four to eight angled, the sheaths with four to eight awl-shaped slender teeth.

Newman's British Ferns, p. 51.-E. limosum.-English Botany, t. 929. -English Flora, rol. iv. p. 326.-Hooker, British Flora, ed. 4. rol. i. p. 394 .

Root, whorls of black fibres from the base of the submerged sheaths, and the joints of the long dark brown spreading rhizomas. 
The stems are extremely variable in size and luxuriance, from two to four feet long, and are quite simple, and terminating in a spike, or barren, or are more or less furnished with perfect whorls of about twenty nearly erect simple branches, of greater or less length, or im. perfect whorls of few branches. The stem is always erect, and the lower part submerged, the whole plant is smooth, but the submerged portion is glossy. The joints are about an inch apart, and striated, with from ten to twenty slightly elevated ribs, which become more distinct after the plant is dry; the lower joints are always naked, but the upper ones are more or less furnished with whorls of branches. The sheaths are short for the size of the plant, close at the base, but more open at the top, and furnished with about sixteen black awlshaped teeth, with a very narrow paler membranous margin to each, the lower part is usually green, like the stem, but occasionally they are altogether black, and especially those in the lower part of the stem. They are striated with from ten to twenty ribs, which are prolonged into the apex of the teeth; the branches are ascending, simple, more or less numerously jointed, and from four to eight angled, each of the striæ becomes double before entering the sheath, but again unite before reaching the point of the sheath, which are from four to eight in number, awl-shaped, with a black tip. The spike ovate, obtuse, terminal, short, and elevated on a short footstalk, swollen upwards, the scales are black, about a hundred in number.

Habitat.-Marshes, pools, ditches, and occasionally in running streams.

Perennial ; in fruit in June and July.

This species is a generally distributed and common plant, and used, according to Linnæus, in Sweden as food for cattle, in order that the cows may give more milk; and in his "Lachesis Lapponica" he observes that " the rein-deer fed with evident avidity on the Great Water Horsetail (Equisetum fluviatile), which the Laplanders call Aske, though it was in a dry state, and though they will not eat common hay. How unaccountably negligent," he continues, "are the Laplanders not to collect in the course of summer a stock of this plant and of the rein-deer moss (Lichen rangiferinus) for winter fodder! They would then have some provision for the berd when the country is covered with an impenetrable crust of frozen snow, and not hazard the loss of all they are worth in the world." It does not appear, however, to be a favourite food with cattle, though occasionally eaten from choice by them. A remarkable circumstance 
relative to this plant is related by Mr. Knapp in his "Journal of a Naturalist." He says, "A large stagnant piece of water in an inland county with which I was intimately acquainted, and which I very frequently visited for many years of my life, was one summer suddenly infested with an astonishing number of the short-tailed water rat (Arvicola amphibia), none of which had previously existed there. Its vegetation was the common product of such places, excepting that the larger proportion of it was densely covered with its usual crop, the Smooth Horsetail (Equisetum fluviatile). This constituted the food of the creatures, and the noise made by their champing it we could distinctly hear in the evening at many yards' distance."

The drawing which we have given of this species is of the natural size and proportion of an ordinary grown plant, but it is subject to

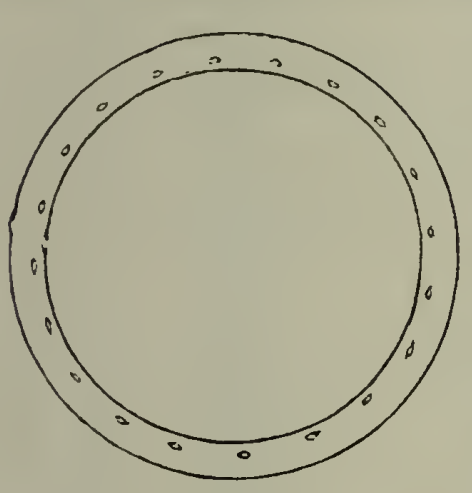
great variations as to size, and in being simple, or with from one to six or eight whorls of branches, and these branches, though usually short, are sometimes long, and short and long ones are very commouly mixed together on the same plant. They, too, are very various in number; occasionally they are as numerous as there are striæ on the stem, but more generally they are much fewer and very variable in number. Sometimes the branches of the upper whorls become proliferous, similar to the variety which we have illustrated of $E$. palustre.

From the magnified joint of the branches given in our illustra tion, and the above transverse section of the stem, it will be seen how distinct it is in its characters from all our other species.

\section{$\S \S$ Stems uithout branches, or rarely branched.}

7. E. hye'male, Linn. (Fig. 1573.) Rough Horsetail. Fertile and barron stems similar, simple, or branched at the base, erect, rery rough, with fourteen to twenty-one ribs; sheaths close, cylindrical, whitish, with a black rim at the top and base, and with as many teeth as there are ribs on the stem, the mid-rib furrowed, and with two slender lateral ones towards the top, united at the apex of the slender but deciduous point, the teeth of the floral sheath always persistent; spike small, black, pointed.

English Botany, 915.-English Flora, vol. iv p. 326.-Hooker, British Flora, ed. 4 vol. i. p. 394.-Newman's Ferns, p 17.

Root fibrous, branched, black, as is the branched rhizoma, which 
creeps to a considerable extent. Stem mostly erect and simple, when branched it is only a single one from the lower joint, and inserted below the black ring of the sheath. The ribs are very variable in number, depending upon the size of the stem, but rarely more than twenty, very rough, with silicious particles, the internodes are two inches long or more, cylindrical, or somewhat swollen in the middle. The sheaths are various in number, mostly about fourteen, and are generally shorter and smaller towards the top of the stem; the ribs are the same number as those of the stem, with a shallow furrow, which is continued into those of the stem also, but rendered less distinct by the silicious particles; they are nearly cylindrical, but rather wider at the top, at first they are of a pale green colour, with a black margin, afterwards becoming entirely black, and ultimately the central part is changed into white, leaving a black ring at the base and margin; the teeth are black, membranous, flexuous, bristle-shaped, but soon fall away, and leave the margin crenated: the upper sheath is funnelshaped, and its teeth are always present. The spike is ovate, small, dark, with a terminal point, at first sessile in the bosom of the sheath, but when matured elevated on a short footstalk.

Habitat.-Boggy shady places; not common, especially in the Midland and Southern Counties of England.

Perennial; in fruit in July and August.

The quantity of silicious particles deposited in the cuticle of this species is greater than in that of any other, and from this great roughness rendering it a natural file, it has been from time immemorial used for polishing wood, ivory, brass, \&c., and is still sold in the shops for that purpose under the name of Dutch Rushes, a name they have obtained from the circumstance of their being imported from Holland, where on the banks of the canals, \&c., it grows in great profusion, and is of essential use from its strong matted roots binding and holding up the embankments. It was formerly used as an astringent, and for stopping bleeding at the nose, but for these purposes it is now quite out of use.

We are told by Lightfoot, in his Flora Scotica, that " some entertain an opinion that if cows chance to feed upon" this Equisetum, " their teeth will drop out; how far this may be true," he further adds, "I know not, but I am persuaded that the pasture must be very bad when they are compelled to eat such food." The same author tells us that in Northumberland the dairymaids use them for the purpose of scouring and cleansing their milk pails, \&c. A very re- 


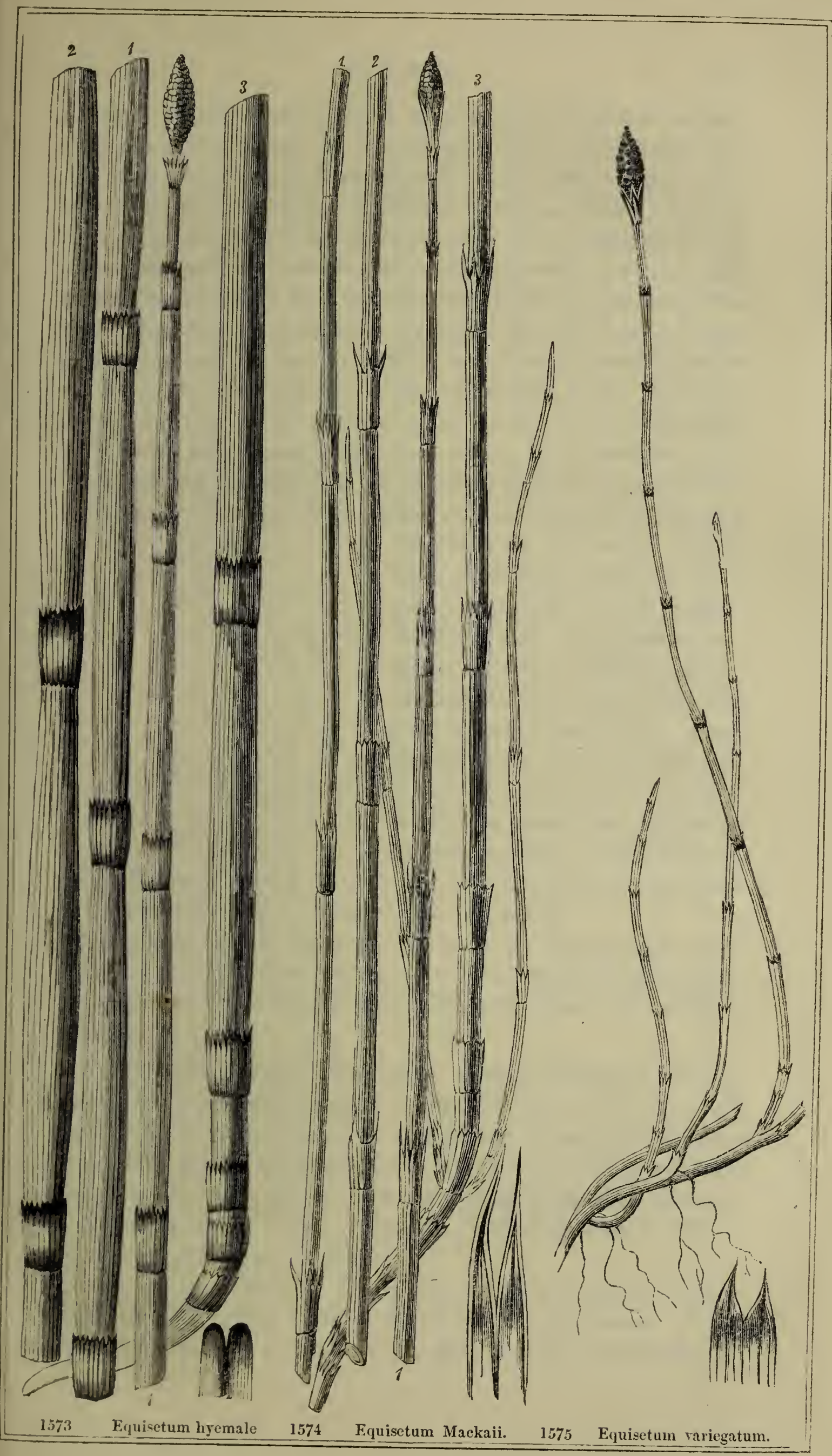



markable formation of spikes on the stems of this species has been observed and described by Mr. Brichan, in the Phytologist, 374. He says, "On the top of many stems of $E$. hyemale I observed a pile of small, dark brown, membranous, elastic, conical, inverted sheaths, of the same substance as the teeth of the sheath which embraces the catkin, increasing in width upwards, and so closely embracing each other that the rim only of each is seen, except the highest and largest, which gives the top of the pile a conical shape. Although scarcely an inch in length, it resembles an inverted abortion of the plant. Its lower end is at first inserted in the uppermost sheath, and surrounded by several small sheaths of a texture similar to its own, and placed within each other. It is afterwards quite protruded, and gradually falls off, leaving a flexuous apex, somewhat like that of the catkin, whose formation I am persuaded it precedes.

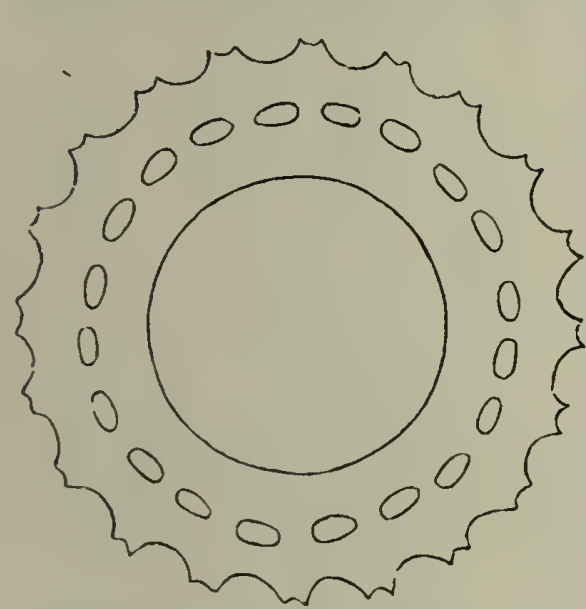

On dissecting the top of several stems, from which the pile of cones seem but recently to have fallen, I found the germ of the catkin completely enclosed within its sheath, the teeth of which not yet separate, form by their union the apex, which appears when the pile falls off. Dissection, however, when the cones are present, seems often to discover an abortive germ. The number of inverted sheaths in one of these piles are about twelve; what their peculiar function may be I cannot even conjecture."

Our illustration of this species is that of an ordinary sized speci; men, and we have krawn it of the natural size, but the sheath given in the plate, and the above transverse section of the stem, are magnified portions.

8. E. Muck'aii, Newm (Fig. 1574.) Mackay's Horsetail.. Fertile and barren stems similar, simple or branched, erect, very rough, with eight to fourteen impressed ribs; sheaths close, cylindrical, becoming black, with slender awl-shaped teeth, having pale membranous margins, as numerous as the ribs of the stem; spike small, black, pointed.

Newman's Ferns, p. 25.-Babington's British Botany, p. 391.$\boldsymbol{E}$. elongatum, Hooker, not Willd.

Root, branched fibres, in whorls frorn the long creeping branched black rhizoma. Stem mostly several from the same branch of the rhizoma, and often branched at the base, and occasionally one or 
two branches from the upper joints, but usually the stem is simple, slender erect, and from one to two feet high, striated, with from eight to fourteen furrowed ribs, very rough, the internodes are about an inch and half long, the sheaths are close, cylindrical, at first the same colour as the stem, or paler, with a narrow black band immediately under the teeth, and at length the whole sheath becomes black, the ribs are the same number as the stem, and termiminating in black slender awl-shaped teeth, with pale membranous margins, brittle, occasionally two or three are united together, the spike is small, black, compact, pointed, at first enveloped at the base with the enlarged sheath, but becoming elevated on a short pedicel.

Habitat.-Moist banks in Mountain Glens in the North of Ireland and Scotland.

Perennial; in fruit in July and August.

This species, which is nearly allied to $E$. hyemale, as will be seen from the magnified section given in p. 31, also from the general formation of the plant, and the identical arrangements of their structure, from which however, it is known as a

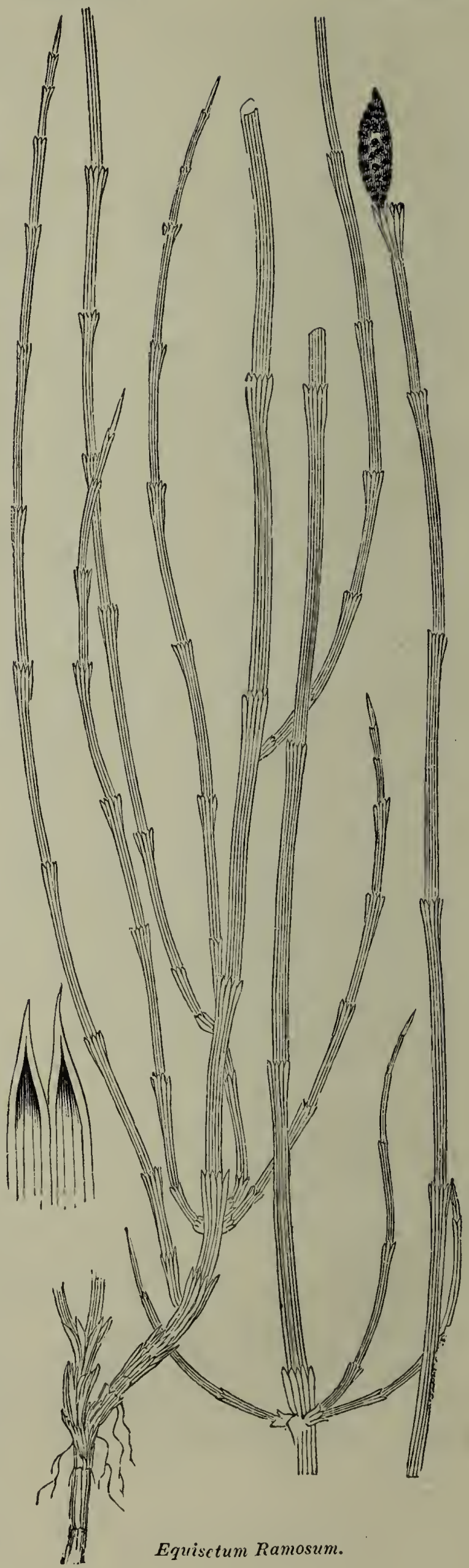




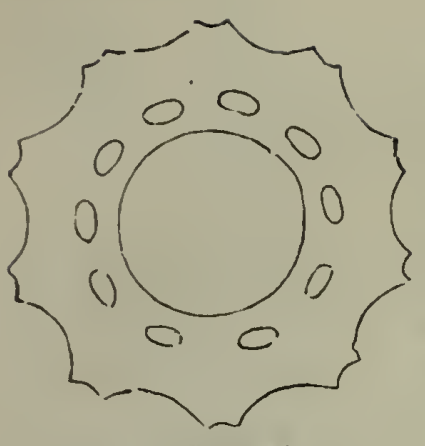

E. Mackaii.

species by the sheaths becoming quite black, the teeth persistent, with a pale membranous margin, sometimes entirely white. It has been referred by Sir W. J. Hooker to $E$. elongatum, of Willdenow : but Newman has shown that it is distinct from that species, and also that $E$.elongatum is the same as $\boldsymbol{E}$. ramosissimum, of Desfontain, which is the $E$. ramosum, Schleicher, and is distinguished by being always of a glaucous green, the brunches from the joints solitary, or in whorls of from two to ten, very slender, often the stem is much branched at the base, and greatly elongated; the sheaths are the same colour as the plant, those of the stem are nearly close, with from eight to ten ribs, those of the branches are more swollen and looser, and from six to eight ribbed; the teeth are lanceolate, awl-shaped, and four ribbed, they are dark at the base, and the colour is continued into the midrib, but mostly the upper ones both of the stems and branches are without colour, or only a pale stain at the base, and generally the two and sometimes three of the lower radical sheaths are entirely dark brown or black; the margins of the teeth are always pale, mostly a pure white, and membranous, the points soon fall off, rarely persistent; the spike is small, ovate, compact, with black scales, the terminal one acuminated into a point, the sheath of the spike is much dilated at the top, and its teeth are in all the specimens which we

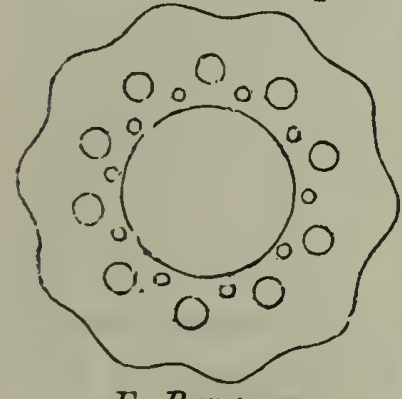

E. Ramosum. seen decidnous. We have given illustrations of this species from specimens collected on the banks of rivulets near Balè, in Switzerland; it is not unfrequent also on the sand banks of the mountain streams of Lucca, Italy. The magnified portion of the stem shows its near affinity to the $\boldsymbol{E}$.palustre in the internal arrangements of its vessels, but in other respects they do not seem to approach each other.

9. E. variega'tum, Schleich. (Fig. 1575.) Variegated Rough Horsetail. Fertile and barren stems similar, with simple whorled branches, mostly decumbent, with six to eight furrowed and impressed ribs, roughish; sheaths short, slightly swollen upwards, the teeth six to eight, lanceolate, with pale membranous margins, the mid-rib projected into a bristle-shaped point, which falls away, and the teeth become ovate, the upper sheath much the largest, with broader four ribbed teeth, united at the point; spike small, ovate, pointed. 
English Botany, t. 1987.-English Flora, vol. iv. p. 307.-Hooker, British Flora, ed. 4. vol. i. p 394.-Newman's Ferns, p. 31.

B. Wilsoni, Newman. Larger, stouter, erect, smoother.

Newman's Ferns, p. 39.

Root fibrous, often woolly, in whorls from the dark branched spreading rhizoma. Stems short, mostly decumbent, with short internodes, about eight rather deep furrows, rough, with silicious particles, the ribs channeled, and terminating in the lanceolate cuspidate teeth of the sheaths, which are short, close, the upper ones somewhat swollen towards the margin, the teeth are dark brown or black, with a thin pale membranous margin, the upper floral sheath is larger, funnelshaped, and embraces the lower part of the spike until it is matured, the teeth are broader, four ribbed, but the ribs are united at the point, the long slender point of the teeth often fall away, and the point is then rounded. Spike small, ovate, black, with an obtuse point, at first sessile in the bosom of the upper sheath, but afterwards it is elevated on its own footstalk, the scales are about twenty in number.

Habitat.-Sandy places near the sea. The Mouth of the Mersey, Southport, Lancashire; Teesdale, Yorkshire; Irthing, Cumberland. In Scotland, the Sands of Barry, near Dundee; the Banks of the Dee \&c. In Ireland it is not unfrequent, especially at Port Marnock and Mucross. $\beta$. New Brighton, opposite Liverpool ; Mucross, near the Lakes of Killarney, growing in water.

Perennial ; in fruit in June and July.

This species is nearly allied to the two, E. hyemale and E. Mackaii, in the structure of the stem, as will be seen by the transverse sections

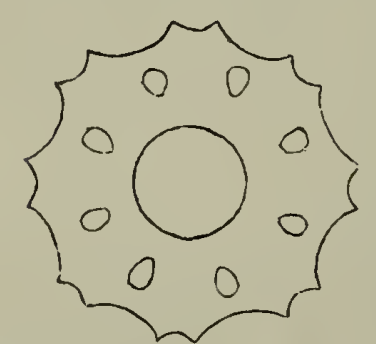
of each of the species; but this in its usual form of growth is a much smaller, low, procumbent, or ascending plant. It is, however, subject 'to very great variations, and the variety Wilsoni approaches very nearly in its size, its erect growth and structure to $E$. hyemale, indeed it seems difficult to fix upon characters which are sufficiently permanent by which one may be known from the other, and so conflicting are the opinions of those Botanists who have paid the greatest attention to the subject, that we rest for the present satisfied to continue it as a variety of this species, until further observations may enable us to determine. 


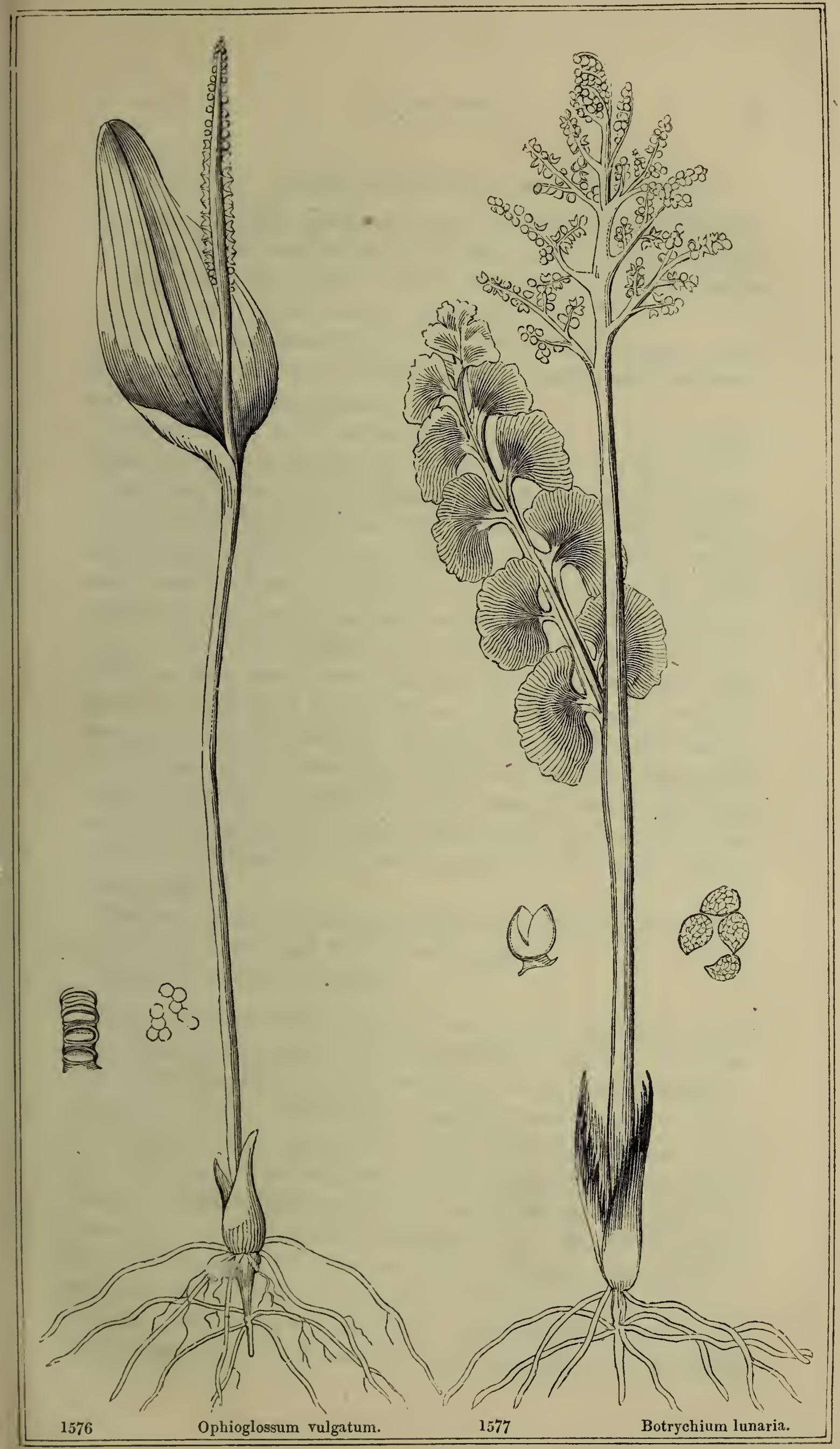




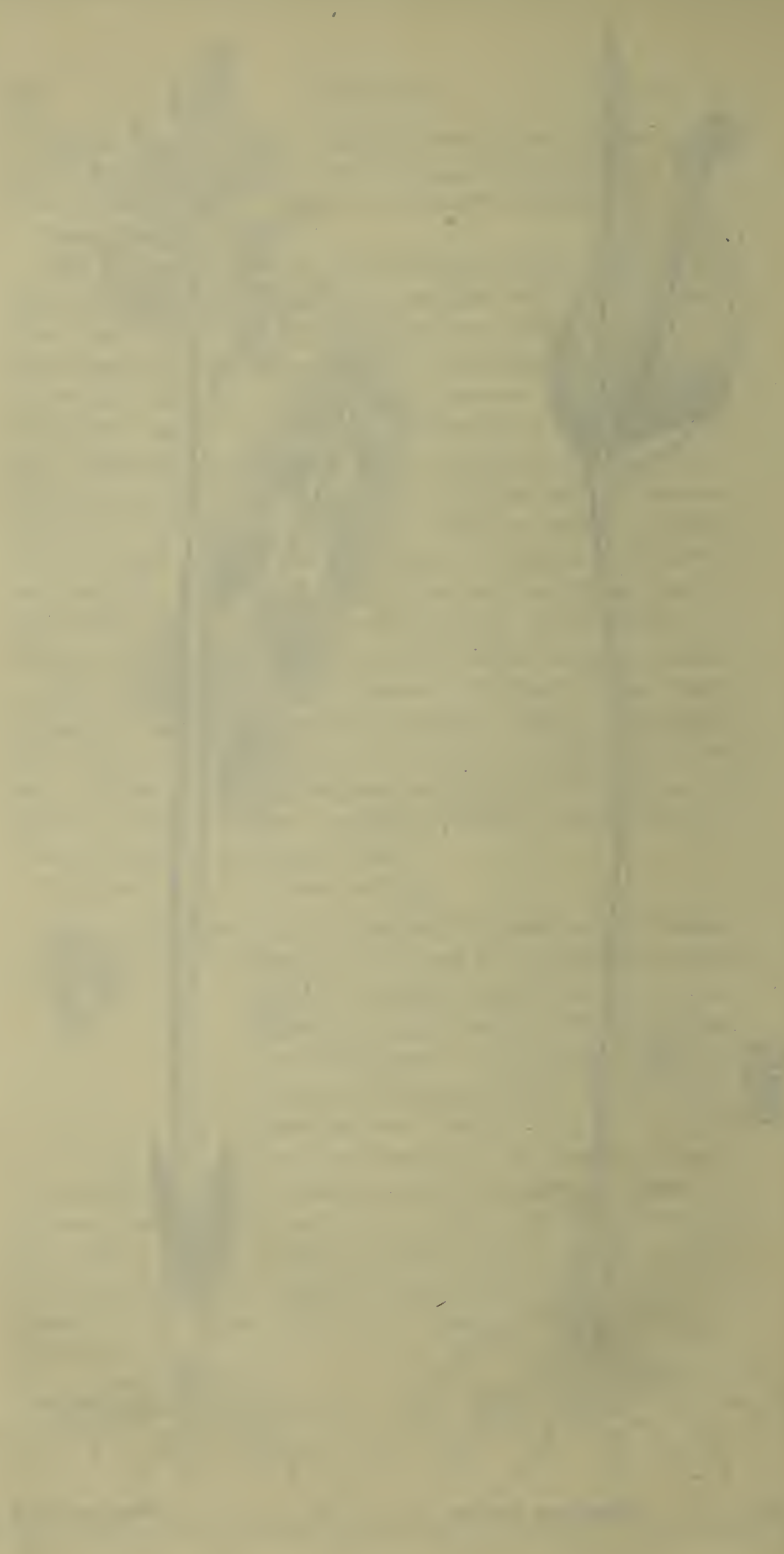




\section{GENUS I. OPHIOGLOS'SUM.-Linn. Adder's-tongue.}

Gen. Char. Thece ollong, two valved, arranged in a straight clubshaped spike, attached to an undivided frond.-Name $\circ \phi_{65}, \circ \phi_{\circ} \circ 5$, a serpent; and $\gamma \lambda{ }^{\prime} \sigma \sigma \alpha$, a tongue; from the supposed resemblance of the spike to the tongue of a serpent.

1. O. vulga'tum, Linn. (Fig. 1576) Conmon Adder's-tongue. Frond simple, bearing above the middle an ovate sessile frond, and terminating in a club-shaped spike.

English Botany, t. 108.-English Flora, vol. iv. p. 316.-Hooker, British Flora, ed. 4. vol. i. p. 391.-Newman's British Ferns, p. 349.

Root long, succulent, and brittle, in irregular whorls from the main root, which descends perpendicularly a considerable depth. Rhizoma short, fleshy, bearing a solitary frond rarely two, and a lateral bud, which forms the frond the following year. Frond erect, hollow, about four inches long, scaly at the base, straight in vernation, very smooth, round, and hollow, succulent, pale yellowish green, bearing above its middle a sessile ovate rather acute leafy frond, quite smooth, dark green, with numerous fine nearly parallel veins, more or less netted towards the point and margins. Spike linear, club-shaped, formed of a row on each side of circular or ovate thece, imbedded and closely crowdea, opening transversely for the escape of the sporules, after which the concave valves remain widely gaping, they are pale brown, thin and membranous. Sporules numerous, very small, globose, almost white.

Habitat.-Moist pastures and woods; not unfrequent in England, less common in Scotland, Wales, and Ireland.

Perennial ; in fruit in August.

This very curious little fern is by no means a rare plant, but in some parts of the country is so abundant as to seem to usurp the place of the grasses in the meadow lands, and is thought greatly to injure the crops. Occasionally remarkable varieties are found, in which there are from two to six spikes developed, but these are of rare occurrence, while fronds not bearing any spike are very general, indeed often more abundant than the spike-bearing ones, and sometimes they are found double, which seems to be the spike developed into a frond instead of forming its capsules, and sometimes the fronds are found cut or lobed at the base. Formerly the bruised fronds of this plant boiled in oil was used as an application for the cure of cuts and bruises, and it would seem to be still used for the same purpose 
in some parts of the country. Our illustration of this species is drawn of the size of an ordinary grown plant, the portion of the capsules are drawn magnified to show their structure and arrangement, and the few sporules are magnified very considerably, but with the same power as those of the Botrychium lunaria on the same plate, to show their relative proportions.

\section{GENUS II. BOTRYCH'IUM.-Sw. Moon-wort.}

Gen. Char. Theca globose, two valved, arranged in clusters on the margin of a compressed branched spike. Name Bcrøvs, a bunch of grapes; in allusion to the branched clustered rachis.

1. B. Luna'ria, Sw. (Fig. 1577.) Common IVoon.wort. Frond erect, bearing a solitary pinna, with lunate pinnules, and terminating in a branched spike of clustered thecæ.

Hooker, British Flora, ed. 4. vol. i. p. 391.-English Flora, vol. iv. p. 315. Newman's British Ferns, p. 33\%.-Osmunda.-English Botany, t. 318.

Root long, succulent, brittle, whorls, arising in an irregular manner from a rather thick central perpendicular one. Rhizoma short, clothed with brown membranous scales, and enveloping the rudimentary buds of the two succeeding years. Frond erect, straight in vernation, from three to six inches high, round, smooth, hollow, bearing about its middle a single pinna, of a pale somewhat glaucous green, quite smooth and glossy, the pinnules alternate and opposite, from three to eight puirs, fan-shaped, entire, or waved or lobed on the margin, and sometimes the lower ones bear thecæ, and seem to be fertile; the veins all arise from the base, and are unequally and irregularly branched, terminating in the margin. Spike terminal, branched, compressed, bearing on its margin sessile globose thecæ, more or less crowded together. Thece rather large, smooth, globose, brown, of two concave valves, containing a vast number of white sporules, globose or angular, formed of a very delicate netted transparent mem. brane, extended by an internal ring, most beautiful under a powerful microszope. Rachis round, smooth, hollow, having four bundles of tubes running through the lower part, two going to the pinna and two to the spike, each branch runs one on one side of the pinna and spike, and the other along the opposite, and gives off a filament to each pinnule and branch of the spike, which are again divided into the veins, and terminate in the thecæ of the spike, the trunks or 
chief branches are united at the base into two, and one seems to originate in the upper whorl of the roots, the other in the lower.

Habitat.-Dry mountain pastures; generally distributed throughout England, less common in Scotland, Wales, and Ireland.

Perennial; in perfection in June.

The Moon.wort appears to have been much esteemed by the old botanists and physicians, and many wonderful effects are attributed to it; but as the signature physicians placed more confidence in the form of the plant than the testing of its virtues, so we presume they must have done in the account they give of the virtues of the present plant, and used their imaginative faculties rather than reason and observation, for it seems to have been used, according to Gerarde, among the alchymists and witches in their dreams and illusions, as well as a remedy for the cure of dysentery.

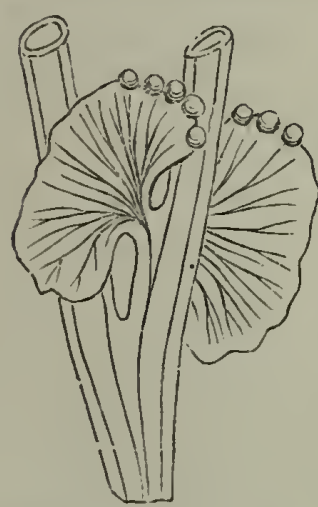

The illustration which we have given of this plant is of the natural size and proportions of an ordinary grown plant. The theca is magnified to show its structure, and the sporules are, as seen under the same magnifying power, as those of Ophioglossum vulgatum. The marginal sketch is that of the pinnules of a frond bearing thecæ on the margin. It also shows the veins and the manner of their distribution, and the loollow rachis and the bundles of tubes passing down.

Several curious varieties are mentioned as having been found of this species : the three following are mentioned by Smith :-

$\beta$. Lunaria minor ramosa, Ray ; $\gamma$. L. racemosa minor adiantifolio, Breyn ; . L. minor, foliis dissectis, Ray. And of these he remarks, " $\beta$. has a branched stalk, bearing several leaves and compound spikes, alternately disposed; $\gamma_{0}$ is a very slight variety, with more jagged leaflets than ordinary; $\delta$. has pinnatifid leaflets, and more spreading habit. All these varieties, and perluaps others, are found occasionally, intermixed here and there, with the plant in its proper or common form; but never, as far as I could learn, so numerously as to have the appearance of a distinct species." 
GENUS III. OSMUNDA.-LiNN. Osmund royal or flowering fern.

Gen. Char. Theca terminating the frond in branched spike-like clusters.-Name of doubtful origin.

1. O. rega'lis, Linn. (Fig. 1578.) Common Osmund-royal. Fronds bi-pinnate; pinnules oblong, obtuse, nearly entire, somewhat auriculated on the lower side at the base ; fructification in terminal spiked elusters.

English Botany, t. 209.-English Flora, vol. iv. p. 314.-Hooker, British Flora, ed. 4. vol. i. p. 139.-Newman's British Ferns, p. 331.

Root strong long fibres. Rhizoma large, thick, and tufted. Frond erect, bi pinnate, varying in height from four to about twelve feet. Pinne opposite, rarely alternate, six to twelve inches long, with opposite or alternate pinnules, on a smooth channeled tapering branch of the racbis. Pinnules linear oblong, obtuse, dark green above, paler beneath, mostly auriculated on the lower side at the base, the margin entire, waved or lobed, the mid-rib prominent, the lateral veins numerous, slender, furked from near the base, and often again divided, terminating in the margin, the upper pinnæ of the frond are converted into a spike like cluster of thecæ, mostly much crowded, each pinnule forms a branch of the spike by its mid.rib, while the foliaceous part of it is changed into the numerous thecæ. It is not unfrequent to find specimens which have the pinnæ partly changeci into thecæ, while the remaining portion retains its leafy structure, affording a beautiful example of the leaves forming the fruit. Thece globose, opening with two smooth concave valves, at first green, becoming brown. Sporules numerous, ovate, smooth. Rachis roundish, smuoth, channeled above, green, becoming brownish, solid, and circinate in vernation.

Habitat.-Wet boggy places, margins of woods, \&c.; a generally distributed plant, very frequent in the North-west of England, but most abundant in Ireland.

Perennial; in perfection in August.

This is certainly the most striking of our ferns in its port and character, the prince among the present existing British race, and is usually much admired, especially in its wild localities, for its noble bearing and very handsome spike of crowded thecæ.

"Auld Botany Ben was wont to jog

Thro rotten slough and quagmire bog, 


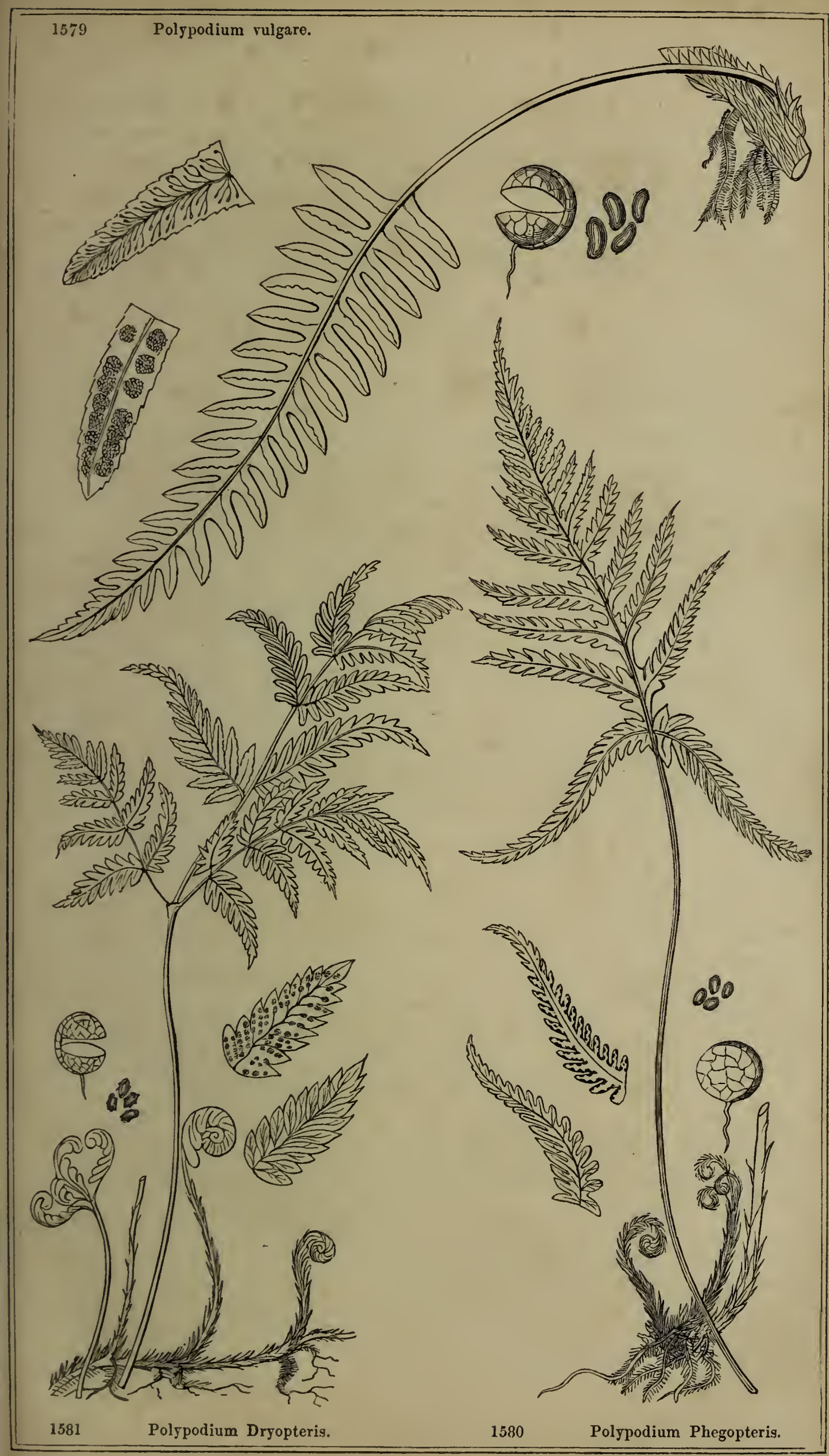



Or brimful dykes and marshes dank,

Where Jack-o'-lanterns play and prank,

To seek a cryptogamic store,

Of carex, moss, and fungns hoare,

Of ferns and brakes, and such like sights

As tempt the scientific wights,

On Winter's day ; but most his joy

Was finding what's called Osman Roy."

The rhizoma possesses astringent and styptic properties, and was formerly used as a tonic and astringent, and considered useful to weakly constitutions, hut it has now fallen into disuse as a medicine.

The illustration of this plant is the full size and proportions of an ordinary sized plant. It will be remarked that some of the pinnæ are partly converted on the margin into thecæ, while the rest retain their proper structure, and by this we are enabled to see that the whole spike is formed in the same manner, and affords us an example of the very beautiful and remarkable conversion of the leaf into the fruit. Each little theca is supplied with a branch from one of the veins, and the two valves into which it bursts are formed by the upper and lower cuticle of the leaf, while the sporules which it contains are the cells of the parenchymal structure converted into propagating particles. The barren fronds differ in no respect from the fertile, excepting the pinnæ being continued to the top, and gradually diminishing in size to the apex.

\section{GENUS IV. POLYPO'DIUM.-Linn. Polypody.}

Gex. Char. Sori circularisclusters. Indusium wanting. Frond flat,

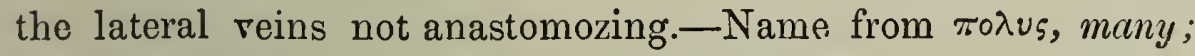
and rovs, a foot; so called from the multitude of roots forming close entangled patches.

1. P. vul'gare, Linn. (Fig. 1579.) Common Polypody. Fronds oblong lanceolate, pinnatifid, the pinnæ linear, obtuse, or acute, entire, crenated, serrated or lobed.

English Botany, t. 1149.-English Flora, vol. iv. p. 267.-Hooker, British Flora, ed. 4. rol. i. p. 382.-Newman's British Ferns, p. 111.

Root brown, fibrous, often clothed with a thick pilosity. Rhizoma somewhat woody, long, creeping, often as thick as the finger, brown, corered with a dense scaly cuticle, which falls off, and leaves the 
rhizoma smooth. Fronds usually about eight inches long, sometimes twenty, erect, becoming drooping, of a cheerful green, smootb, somewhat paler beneath, of a lanceolate or oblong lanceolate or linear form, cut to the rachis, or nearly so, into linear pinna, alternate and rounded or lanceolate at the point, occasionally bifid, the margin entire, equally or unequally serrated, lobed, or cut into narrow linear segments, each with a mid-rib and lateral veins, the lateral veins are alternate, slender, each three or four branched, the first branch arising from the base on the side nearest the point terminates about the middle of the pinna, and bears at its apex the circular mass of thecæ, the others extend to near the margin, and are thickened at the apex. Rachis slender, green, channeled above, naked, or scattered over with a few brown lanceolate scales. Sori naked circular clusters, alternate on the back of the upper pinnæ. Theca numerous, crowded, globose, with a beaded elastic ring, attached at the base by a slender pedicel formed of elongated transparent cells, to the apex of the vein. Sporules ovate, or kidney-shaped, smooth.

Habitat.-Rocks, walls, trunks of trees, rocfs, banks, \&c.; very frequent.

Perennial; in perfection in September.

The figure 1579 of this species, drawn half the natural size, will give an idea of the general form, as it is found on rocks and trees, \&c. The detached pinnæ show the beautiful manner in which the veins are disposed, their obtuse point, and the ordi. nary size and disposition of the clusters of thecæ. The capsule is represented as seen with a greatly magnifying power, as well as the sporiles.

The figure of the frond, however, is subject to great variety, from not more than two inches long, and of a triangular form, to linear lanceolate and oblong lanceolate, and about twenty inches long; and its pinn $\rightsquigarrow$ are subject to some remarkable variation from its normal form of an entire margin. Fig. $a$ (page 39) is a frond drawn the natural size, in which it will be seen the pinnæ are strongly serrated. Fig. $b$ (page 40 ) is a remarkable variety, the end of the pinnæ being bifur. cated irregularly, as well as the margin unequally serrated. This is drawn of the natural size, but is only the lower portion of the frond, the upper half has the pinnæ undivided, and the margins irregularly toothed and waved, almost entire, and bcaring fruit abundantly: for these two specimens we are indebted to Miss S. Ridge. Fig. $c$ are piunæ on the lower part of a frond, which is eighteen inches long; 
the upper pinnæ are lobed and serrated, and the uppermost ones are simply serrated, it is abundantly in fruit. For beautiful specimens of this variety we are indebted to Miss Griffiths, who found them in the neighbourhood of Torbay. Fig. $d$ (page 40) are pinnæ drawn also the natural size, the whole frond measuring twenty-one inches, but its pinnæ are all, except a few, of the uppermost ones, as much

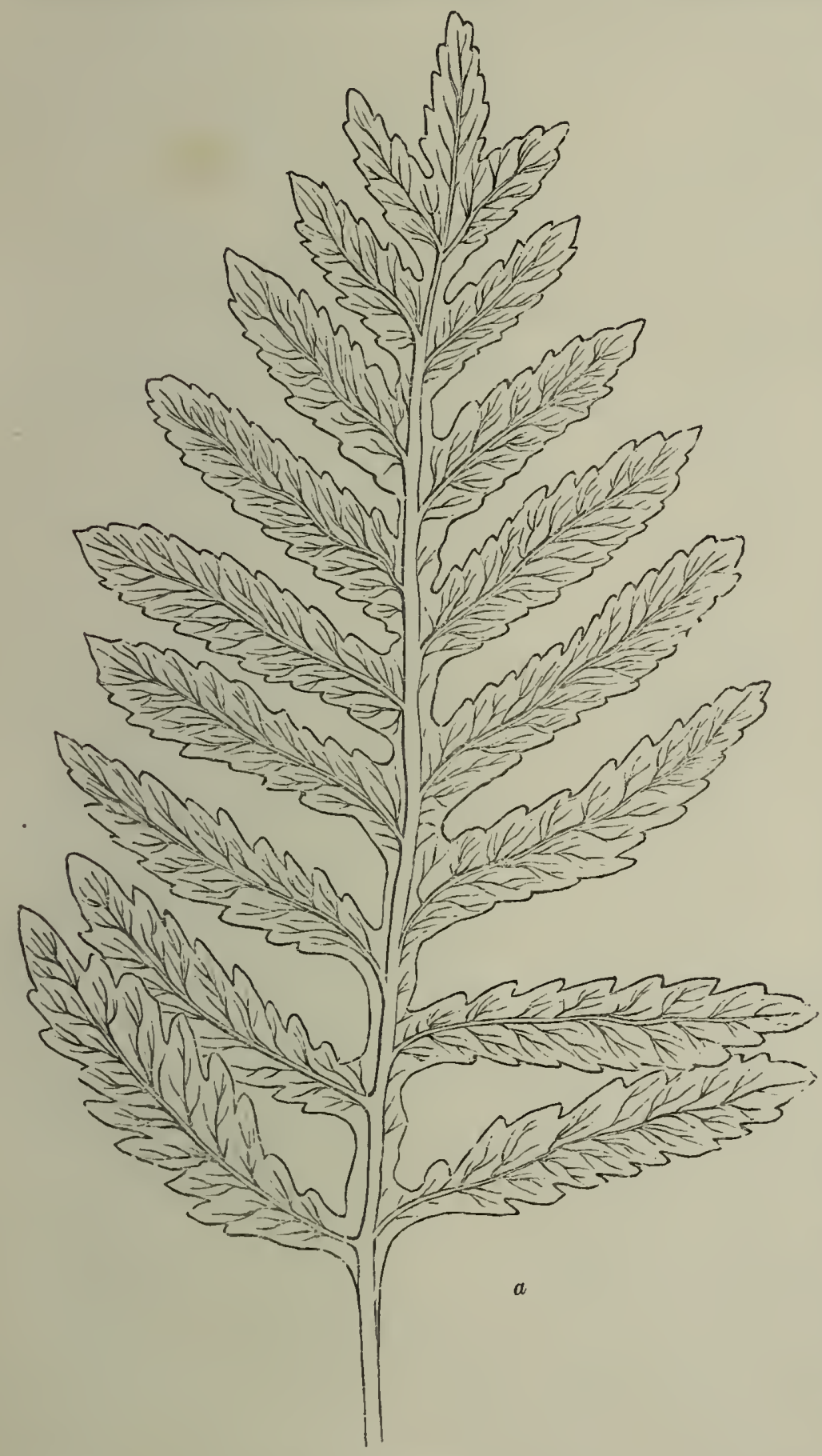

divided: it is the $P$. Cambricum, of Linnæus, and is our most beautiful and ele. gant variety of the species.

The common Poly. pody, or Wall Fern, or Polypody of the Gak, was formerly much es. teemed for its expectorant qualities, and is supposed to be the " rheum purging polypody" of Shakspear, but it is not now used in this country. It is re-

tained in the list of the Materica Medica of Italy, and used by the Italians as a demulcent in the form of a decoction. The fronds, when burned, afford a good deal of carbonate of potass, for which 


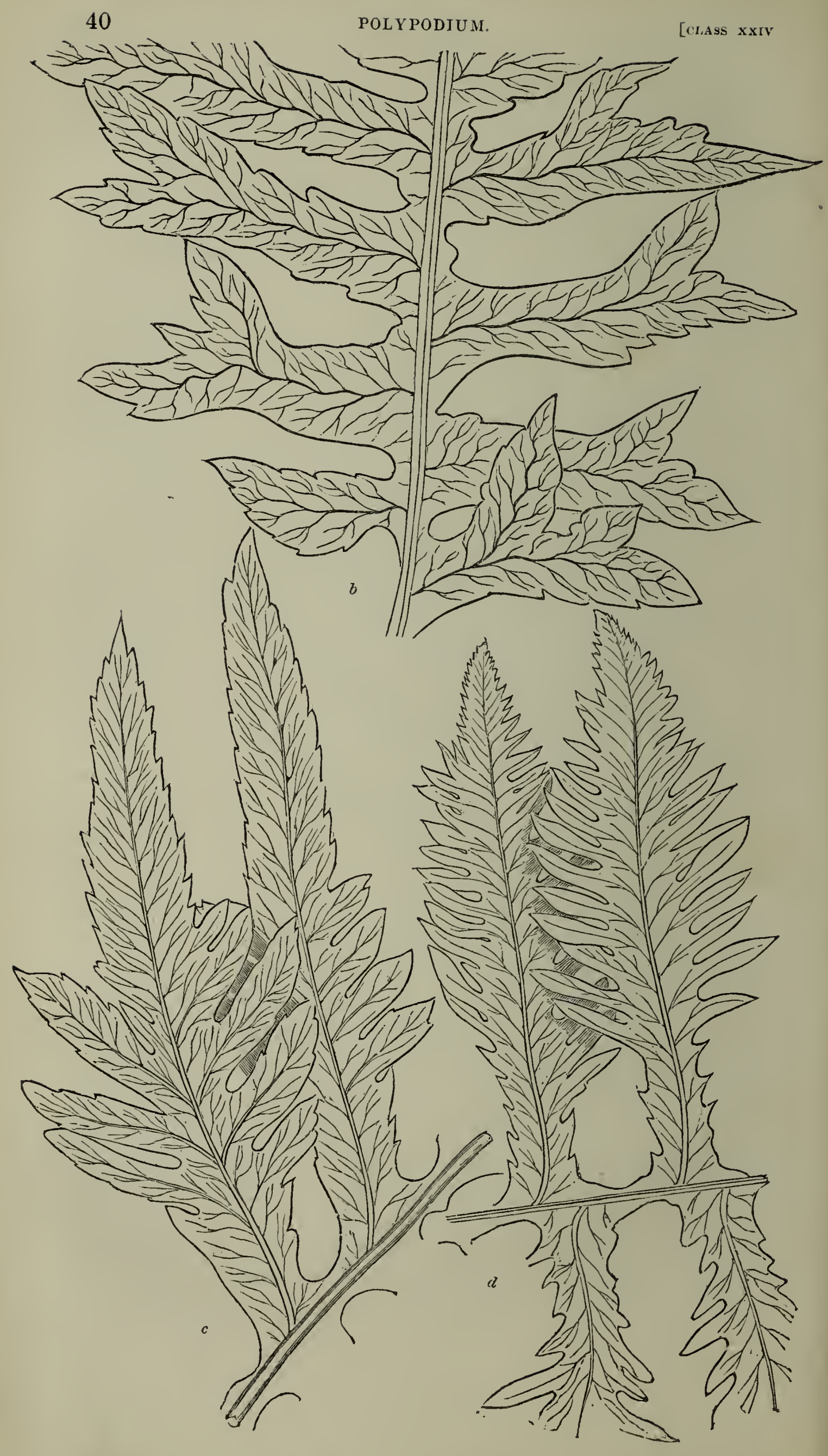


purpose it is often collected. The ashes are boiled in water, and the liquor strained and evaporated until crystals are formed. The common Polypody loves to fix itself upon the trunks of old trees, the stumps of the pollard willow, and hornbeam, and the thatched roofs of buildings, from thence hanging down its graceful fronds in crowded clusters, it forms an elegant and verdant ornament for a considerable period of the year.

2. P. Phegop'teris, Linn. (Fig. 1580.) Pale Mountain Polypody. Frouds triangular, acute, bi-pinnatifid, the pinnæ linear lanceolate, the lower pair standing forward from the others, the lobes ovate, obtuse, ciliated, the lateral veins alternate, mostly undivided; sori marginal.

Finglish Botany, t. 2224.-English Flora, vol. iv. p 269.-Hooker, British Flora, ed. 4. vol. i. p. 383.-Newman's Ferns, p. 115.

Roots long, fibrous, branched, mostly clothed with a thick pilosity. Rhizoma long, slender, thread-shaped, widely creeping. Fronds from six to eighteen inches high, of a triangular acute figure, tapering at the point, the pinna lanceolate, taper pointed, of a pale green, and often nearly smooth above, a dull somewhat glaucous green beneath, and very hairy along the veins, the lower pair of pinnæ standing forward from the others in a very remarkable manner, the lobes divided to the base, or nearly so, oblong, obtuse, or acutely pointed, entire, or the lower ones near the rachis serrated, the margin ciliated, with soft hairs, and somewhat rolled inwards, the lateral veins arise alternately from the middle one, simple, and terminating in the margin, through not unfrequently and especially in the lower pinnæe they are bifid. Sori circular naked masses, attached below the point of the lateral veins near the margin of the pinnæ. Thece small, numerous, attached at the base by a rather thick pedicel, formed of elongated cells. 'Ihe Rachis is long, slender, scattered over with a few lanceolate brown membranous scales, especially at the base, hairy at the top, and mostly twice as long or longer than the part which forms the frond.

Habitat.-Shady rocky places in mountainous districts, especially near water falls; not unfrequent.

Perennial ; in perfection in July.

This beautiful and graceful little plant is often called Beech Fern; it throws up its young fronds in May in an horizontal manner, and in the course of a short time after it is expanded becomes drooping, and if growing upon the side of rocks it is pendulous; but in whatever 
situation it grows, it is at once distinguished from all our other species by the remarkable manner in which the first pair of pinnæ stand off from the others. Its long rachis, triangular shaped fronds, and marginal sori are characters also of marked distinction.

Our illustration is drawn one half the natural size. The detached pinnæ are the third pair and of the full size and proportion, showing the disposition of the sori on one side and the veins on the other. The thecæ is highly magnified, as well as the sporules, which are ovate, smooth.

3. P. Dryop'teris, Linn. (Fig. 1581.) Tender three branched Polypody. Frond three branched, quite smooth, brittle, the terminal branches deflexed, the lateral ones spreading, bi-pinnate, the lobes oblong, obtuse, sub-crenated, the lateral veins alternate, mostly undi. vided; sori marginal.

English Botany, t. 616.-English Flora, vol. iv. p. 269.-Hooker, British Flora, ed. 4. vol. i. p. 383.-Newman's Ferns, p. 123.

Roots fibrous, black. Rhizoma black, wiry, branched, creeping, often netted together. Fronds ascending about a foot high, three branched, the terminal one but little larger than the lateral ones, and is deflexed from the insertion of the lateral ones where it is swollen and apparently jointed; each division of the frond is of a triangular figure, and pinnate, the pinne lanceolate, the lower ones opposite, the pinnules oblong, obtuse, entire, or somewhat crenated on the margin, especially towards the point. The first pair are each about the same size, and inserted into the stem with the rachis, so that they form a cross. The lateral veins are simple, arising alternately from the middle one, which is mostly zig-zag, and terminate near the margin in a crowded cluster of sori, which are often so numerons as to form a continuous marginal line, or they are more distant. Theca very numerous, small, each one with a beaded ring encircling it, and attached by a slender cellular pedicel. Sporules minute, ovate, roughish; the rachis is very slender and brittle, a dark brownish purple, quite smooth, as is the whole frond, except occasionally a very slight downiness along the mid-rib of the pinnæ, and towards the base a few brown membranous scales.

Habitat.-Mountainous districts, especially in the North of England, Wales, and Scotland. Very rare in lreland; Knochlayd, County Antrim; Mourne Mountains, County Down; and Maur Twik.

Perennial ; in perfection in July.

This little Fern is one of our most elegantly formed and delicate 
species, usually locating itself amongst the rocks and stones in the wild and mountainous districts, where it can freely enjoy the pure morning breeze, and be supplied with unpolluted waters.

The drawing of this species is made half the size of an ordinary plant, as it is grown in elevated situations in the mountains of Scotland; but it is found much larger than this in sheltered and favoured situations. The

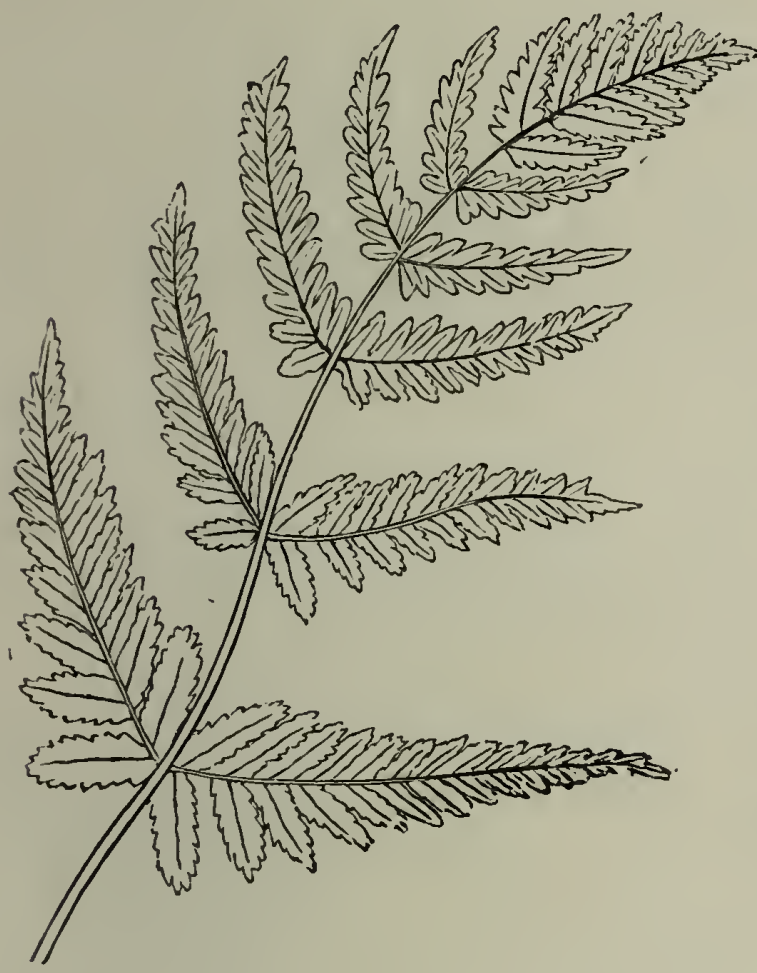
magnified pinnules show the disposition of the veins and the situation of the sori at the back. The theca is highly magnified, showing its beaded elastic ring and slender pedicel, and the ovate sporules minutely granulated. The slender rhizoma, the very beautiful mode of ver. nation, and the manof its developement, may be seen as we have represented them. The accompanying marginal sketch is the terminal branch drawn of the natural size and proportion, by which more distinctly will be seen the disposition of the pinnules, and the cross-like form of the disposition of the first pair of them.

4. P. calca'reum, Smith. (Fig. 1582.) Rigid three branched Polypody. Fronds three branched, all erect, or equally spreading, more or less downy, with short glandular pubescence, bi-pinnate, the lobes oblong, obtuse, sub-serrated, the lateral veins alternate, branched or simple; sori marginal.

English Botany, t. 1525.-English Flora, vol. iv. p. 270.-Hooker, British Flora, ed. 4. vol. i. p 383.-Newman's British Ferns, p. 131.

Roots black, fibrous. Rhizoma black, thread-shaped, branched and spreading. Frond about a foot high or more, three branched, the middle one larger than the others, all equally erect or spreading, and the union of the branches and the lower pinnæ with the stem is 
swollen, as trough jointed: it is of a dull somewhat glaucous green, and more or less covered over, esrecially on the under side and the joints of the stem and pinnules, with short glandular pubescence Pinna lanceslate, all those on the lower side being longer and larger than those on the upper. The pinnules are oblong, obtuse, entire, or waved or serrated, especially at the point, the margin frequently somewhat reflexed; the lateral veins alternately arising from the zig-zag mid-rib, and are simple or branched. Sori marginal, naked, circular clusters, of small pale brown thecæ fixed below the point of the veins. Thece small, numerous, with a beaded elastic ring, attached by a slender cellular pedicel. Sporules ovate, smooth. Rachis slender, green, with a few lanceolate brown membranous scales scattered about its base, and equally covered over with a glandular pubescence as the frond.

Habitat.-Amongst stones and rocks in limestone districts; but not common.

Perennial; in perfection in July.

The specimens from which our description and drawing are made are from Matlock Bath. The whole plant is stouter, more succulent, and not the same delicate green colour as the last species, but of a blue glaucous hue. The branches are mostly erect, never so remarkably curved as in the $P$. Dryopteris. These characters, together with the pale glandular pubescence with which it is covered, readily distinguish it fron all other of our species. We have collected it frequently among the lower Alps of Switzerland, and in France and Germany, and find no difference between those specimens and our own, except that in some of them as grown in higher and more exposed situations become of a brownish purple hue.

Our drawing of this species is made one half the natural size. The theca is highly magnified, to show its beaded elastic ring and ovate roughish sporules. The sketch of the detached pinna, fig. $a$, is drawn of the natural size and proportion, and shows the situation of the sori. Fig. $b$ is a de-

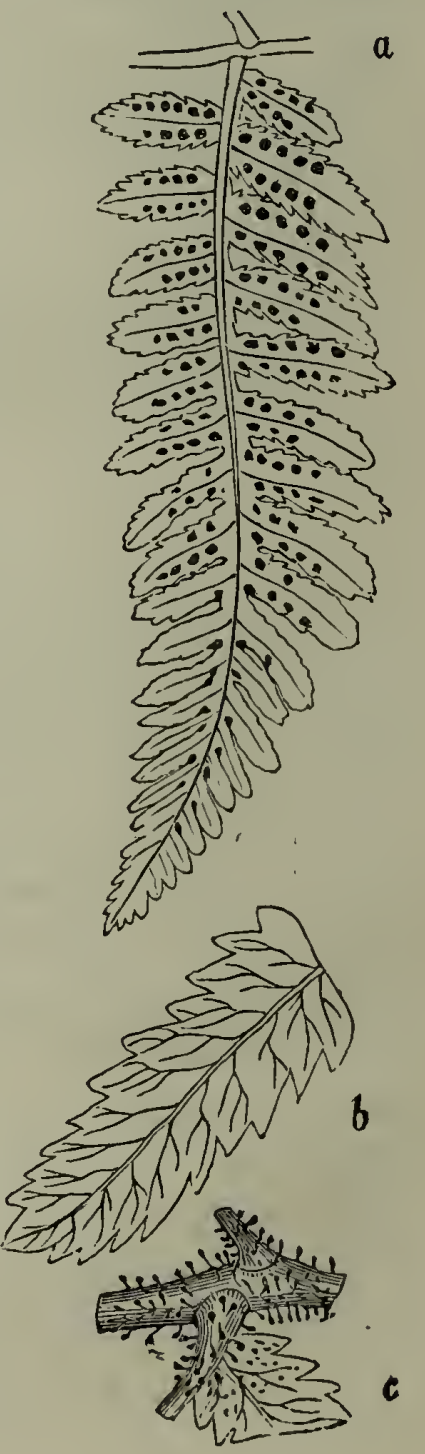




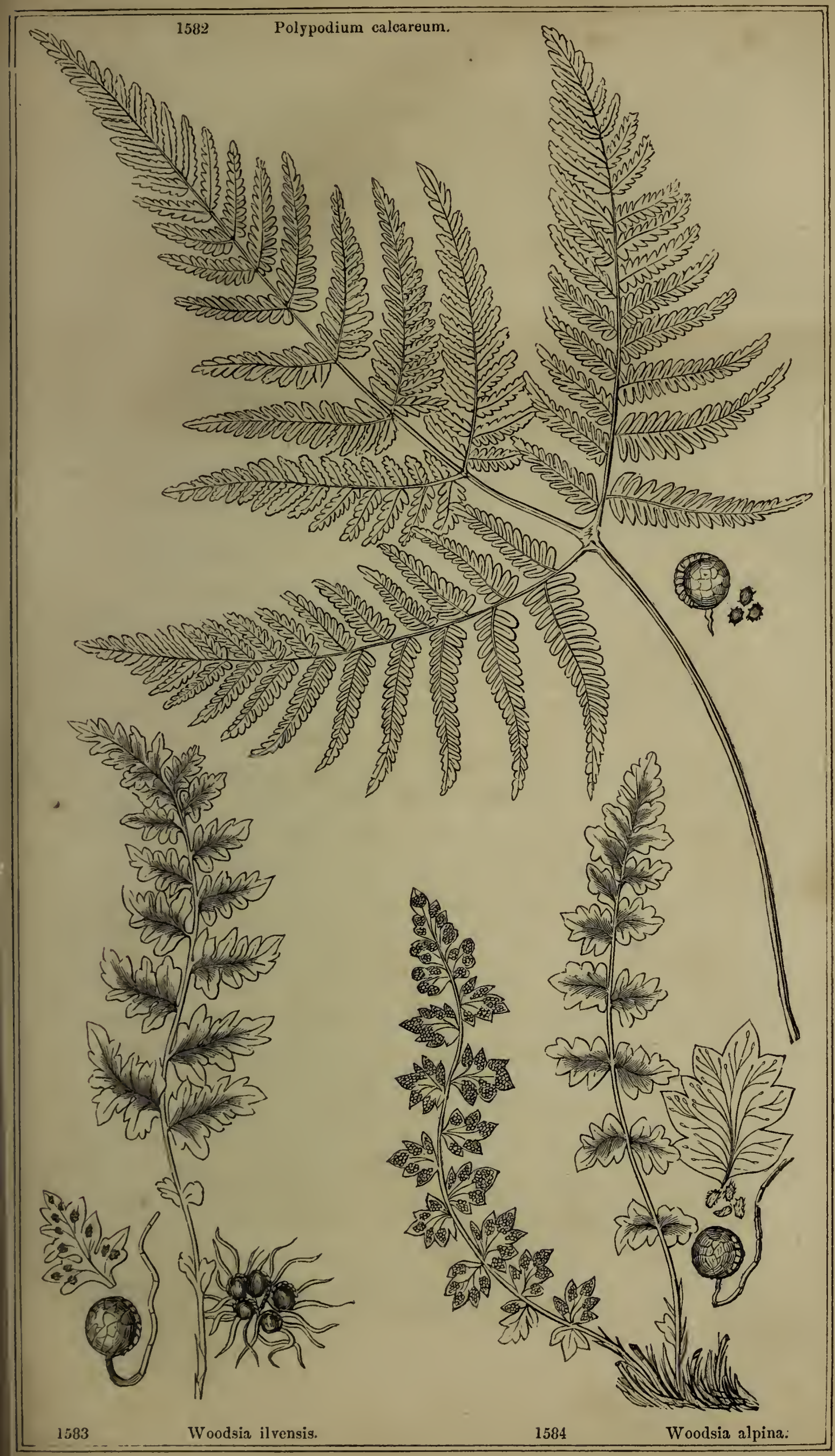



tached pinnule magnified, to show its serratures and the disposition of the mid-rib and lateral veins. Fig $c$ is a magnified portion of the stem, to show the manner in which the pinna is attached by its jointlike union to the stem, as well as the glandular pubescence and the attachment of the pinnule.

\section{GENUS V. WOOD'SIA.-Brown. Woodsia.}

Gen. Char. Sori circular loose clusters, scattered. Indusium cut into numerous mostly capillary segments. Fronds flat, the lateral veins not anastomozing.-Named in compliment to Joseph Woods, Esq., author of an excellent Monograph of the British Roses.

1. W. Ilven'sis, Br. (Fig. 1583.) Oblong Woodsia. Frond oblong lanceolate, pinnate; pinnæ on short stalks, deeply cut into oblong entire or serrated segments beneath, rachis villous and scaly.

English Botany, t. 2616. -English Flora, vol. iv. p. 309.-Hooker, British Flora, ed. 4. vol. i. p. 383.-Newman's British Ferns, p. 137.

Root long, smooth, wiry black sparingly branched fibres. Rhizoma thick tufted. Fronds about four inches high, and mostly many from the same rhizoma. Stem slender, and at about three quarters of an inch from the base, swollen and jointed, and clothed with brown lanceolate membranous scales, mixed with jointed hairs, especially above, pinna opposite in pairs, or alternate, oblong, obtuse, and attached to the stem by a short footstalk, deeply cut into lobes in a pinnatifid manner, and the lobes are either simple or serrated, with obtuse teeth, the upper part is simple, pinnatifid, the upper surface appears smooth until examined with a magnifying power, when it will be found that it is scattered over with a few stout hairs, and that each branch of the lateral veins terminates in a bulb. This is only seen on the upper surface, and is the same as we have represented in the detached and magnified pinna of the following species. The under surface is covered over with jointed shining hairs and long narrow scales, which seem to fall off when the plant reaches maturity. Sori circular clusters, imbedded in jointed shining filaments, which form the indusium near the margin of the lobes, often becom. ing confluent, and almost covering the pinnules. I'heca small, 
globose, encircled with an elastic beaded ring, and attached by a rather thick pedicel.

Habitat.-Mountains in the clefts of rocks; very rare. Near Llyn-y-cwn, on Glyder Vawr, Carnarvonshire.-Dr, Howitt. "Falcoln Clints, about ten miles west of Middleton, in Teesdale." $-M r . S$. Halestone. At the foot of basaltic rocks, on the Durham side of the river Tees, about two hundred yards below Cauldron Snout. -Mr. T. Backhouse. "Glen Phee, Forfarshire."-Mr. Wilson.

Perennial; in perfection in September.

The drawing which we have given of this very interesting little fern is made of the full size, from a specimen collected in the above station by my friend Dr. Howitt. It appears to me identical with the one represented by Newman at page 137, fig. c., which he says was found by Mr. Wilson in the station given in Forfarshire, except the pinnæ being more alternate. The thecæ in our plate are represented as seen mixed with the filaments of the indusium; one is more highly magnified to show its structure and beaded elastic ring, as well as the jointed tubular filament. The detached pinnæ shows the position of the sori.

2. W. alpi'na, Bolton, Newran. (Fig. 1584.) Alpine Woodsia. Frond linear lanceolate, pinnate; pinnæ sessile, triangular, ovate, obtusely lobed, beneath and rachis slightly hairy.

Newman's British Ferns, p. 143.-W. hyperborea, Smith._English Flora, vol. iv. p. 310.-Hooker, British Flora, ed. 4 vol. i. p. 383.$W$. Ilvensis. $\gamma$. Babington Manual of British Botany, p. 384.Polypodium hyperboreum, Sw.-English Botany, t. 2034.

Root long, smooth, wiry, black branched fibres. Rhizoma thick tufted. Frond about four inches long, often less, and mostly several from the same rhizoma. Stem slender, erect or ascending, when young more or less clothed with slender long scales and soft jointed pubescence, but as the plant advances to maturity this seems to fall away, pinna mostly alternate, sometimes opposite and sessile, or with a very short footstalk, of an obtusely triangular form, with obtuse serratures, the first serrature sometimes more deeply cut than the others, and occasionally notched. The upper part of the frond is simply pinnated and pointed, the upper surface is scattered over with a few stout hairs pointed outwards, and each apex of the veins is dilated into club-shaped forms, as in the last species, and, as is seen represented in the magnified pinnæ of our plate, the veins do not seem to take any regular form of arrangement, but all arise from the 
base. Sori circular clusters, imbedded in jointed shining filaments, which form the inclusium near the margin of the lobes; often becoming confluent, and almost covering the pinnules. Theca small, globose, encircled with an elastic ring, and attached by a cellular pedicel.

Habitat.- "On Clogwyn-y-Garnedd, one of the precipices of Snowden which faces the east."-Mr. Wilson. Ben Lawers, Mael-dun. Crosk, Craig.Challiach, Perthshire, Scotland.-Mr. Wilson, $M r$. G. Don, \&c.

Perennial ; in perfection in July.

Our illustration of this beautiful little species is of the natural size of the plant, drawn from specimens collected in Ben Lawers. The detached pinnæ is magnified, to show the mode of its distribution of the veins, and the termination in a club-shaped manner. The thecæ and filament of the indusium are magnified with a high power, to show their structure, as well as the granulated ovate sporules.

Much doubt has been expressed by Botanists as to these two being distinct species, a difficulty which in plants liable to such variation of form must always be great, for it is only on the form of the pinna that the claim of distinction can rest. Mr. Newman, p. 148, says, "Mr. J. Backhouse, jun., after informing me that he collected some specimens of Woodsia at Falcon Clints, proceeds to say,- ' I brought home some specimens with roots, and when I planted them, they agreed in every particular with $W$. Ilvensis: the first fronds they produced after I had planted them were quite different, and had assumed exactly, the form of the Scottish $W$. hyperborea, and they are now (26th of 11th mo. 1842) changing back again to Ilvensis, so that I have no doubt the forms are only two varieties of the same species.'"

GENUS VI. ALLOSO'RUS.-BERnhardi. Rock-brakes.

Gen. [Char. Sori circular clusters, becoming confluent, and concealed by the revolute margin of the frond, the lateral veins not anastamosing.-Name from $\alpha \lambda \lambda \circ 5$, various; and sorus, in allusion to the various appearance of the sori at different periods of their growth.

1. A. crispus, Bernh. (Fig. 1585.) Curled Rock-brake. Fronds bipinnate, smooth, the barren one with oblong wedge-shaped segments, cut, the fertile ones with linear oblong revolute segments, entire. 
Newman's British Ferns, p. 103.-Pteris crispa, Linn.-English Botany, t. 1160.-English Flora, vol. iv. p. 306.-Cryptogramma crispa, Br.-Hooker, British Flora, ed. 4. vol. i. p. 389.

Roots numerous, long, tough, and fibrous. Rhizoma procumbent, creeping horizontally, dark brown, scaly. Frond erect or ascending, quite smooth, of a bright cheerful green, from six to twelve inches high, bi-pinnate, somewhat triangular in its form. Rachis long, slender, green, brittle, quite smooth, except a few brown lanceolate membranous scales at the base, the barren frond bi-pinnate, its pinnules bi- or tri.pinnatifid, the segments very variable in figure, wedge-shaped, and cut in the usual form, but often they are narrow, linear, and bifid, or linear crenated, or ovate oblong and crenated, like a miniature oak leaf; the fertile fronds are usually rather larger than the barren ones, and the pinnules divided into ovate oblong entire segments, the margins are pale, thin, membranous, crenated, and incurved over the sori, tapering at the base into a short footstalk, the lateral veins arise from the zig-zag middle one, and terminate before reaching the margin, those of the barren fronds are mostly simple, but those of the fertile fronds are bifid, and terminate in a mass of thecæ, which become confluent, and formed into coutinuous lines beneath the incurver margin. Theca small, globose, with a beautiful reddish beaded elastic ring encircling it. Sporules ovate, smooth.

Habitat.-Among loose stones in mountainous districts in the North of England, Wales, and Scotland ; very rare in Ireland.

Perennial; in perfection in July and August.

This very beautiful and delicate plant cannot be mistaken for any other of our native species. The barren fronds vary considerably in their size, and the width and shape of their pinnules.

The drawings which we have given of this plant are half the natural size, and of the normal form both of the barren and fertile fronds. Fig. $a$ is a detached pinnule, showing its upper surface and the disposition of its veins; $b$ is the under side exbibiting the incurved membranous margin, almost covering the confluent thecæ; $c$ is the same, one half being turned back, showing the bifid lateral veins and their manner of terminating in the cluster of thecæ, while the opposite side remains in its usual position; $e$ is a small portion of the membranous margin of the pinnule, very highly magnified, and showing the beautiful muricated arrangements of its cells ; $d$ is a barren pinnule, showing its divisions and the disposition of its undivided lateral veins. 


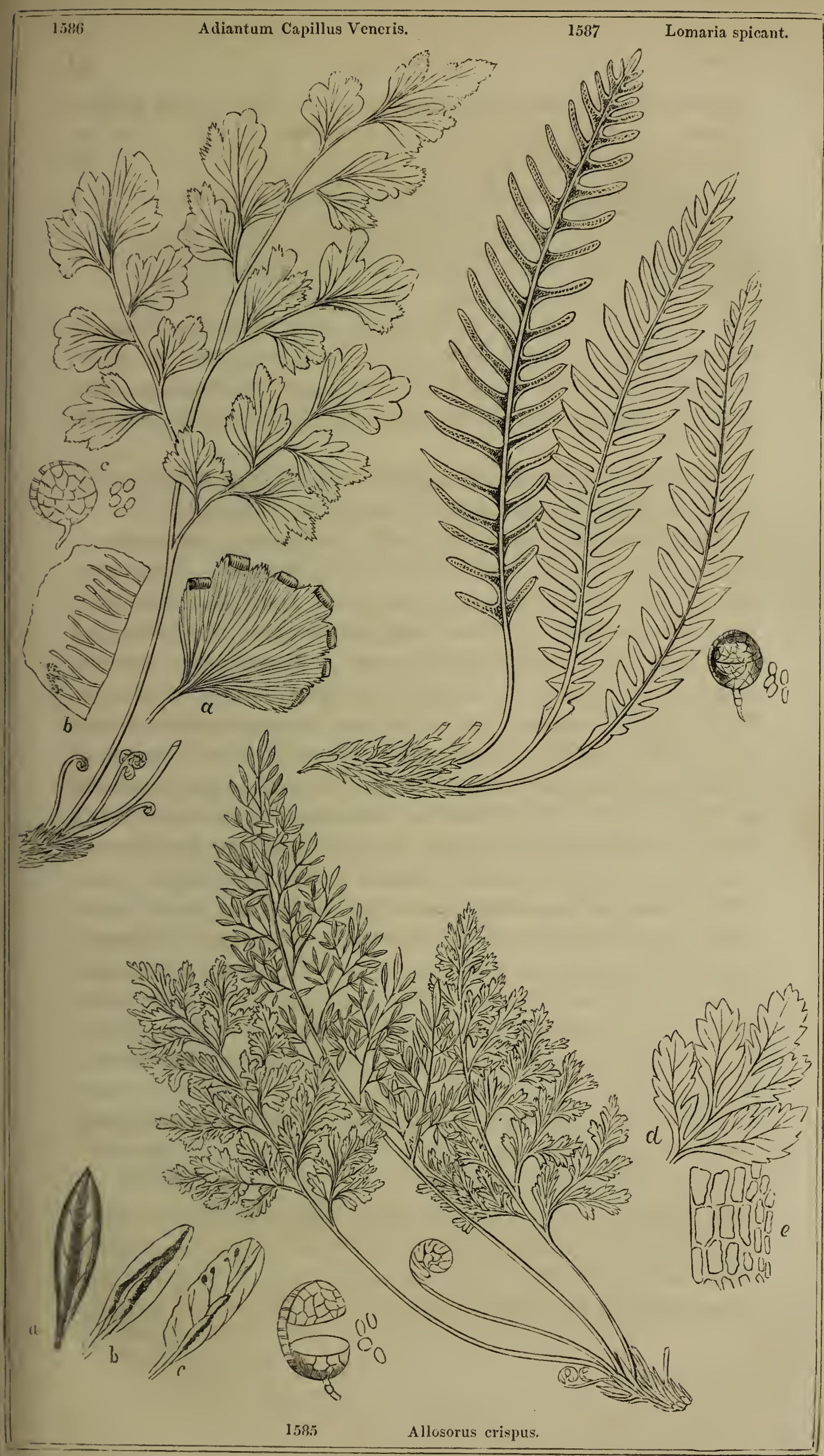





\section{GENUS VII. ADIAN'TUM.-Lins. Maiden-hair.}

Gen. Char. Sori oblong or roundish, covered by a portion of the frond, reflexed, and a prolonged portion of its membranous

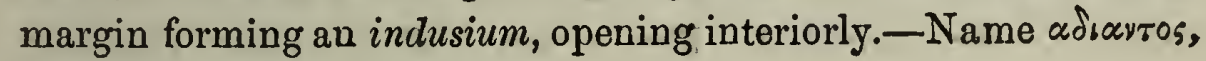
that which is of a dry nature.

1. A. Capillus Veneris, Linn. (Fig. 1586.) True Maiden hair. Fronds bi-pinnate; pinnules alternate, thin, oblong, wedge-shaped, inciso lobate, the ends pale, membranous, reflexed over the linear sori.

English Botany, t. 1504.-English Flora, vol. iv. p. 307.-Hooker, British Flora, ed.4. vol. i. p. 389.-Newman's British Ferns, p. 83.

Roots long, black, wiry, and fibrous. Rhizoma short, thick, black, and scaly. Fronds from six to twelve inches high, erect, or mostly drooping, irregularly oblong lanceolate, bi-pinnate, with alternate black shining thread-like branches, bearing alternate pinnules, with slender short footstalks, ovate, wedge shaped or fan-shaped, more or less deeply cut and lobed, but variable in size and form, sometimes almost orbicular, with the margin entire or serrated, of a thin delicate texture, and a bright cheerful green, some of the lobes of the pinnules are often barren, while the others are fertile, mostly all are fertile, and but rarely that all are barren, the barren ones are finely serrated on the margin, the fertile ones are reflexed, and the thin membranous margin prolonged into an indusium, which covers over the confluent linear sori, these are at first in circular masses at the apex of the veins, but they soon become connected, and form a continuous line, the veins are numerous, slender, branched, arising from the footstalk, but without there being any one more prominently large than the others, repeatedly divided, and terminating in the teeth on the margin or sori under the indusium. Thece very small, globose, encircled with a beautiful beaded reddish elastic ring. Sporules minute, smooth, ovate. Rachis deep purplish brown or black, quite smooth and shining, brittle, often having more than the lower half naked.

Habitat.-Moist rocks, caves, and walls near the sea; rare. Cardew, St. Ive's, and Carrick Gladden, Cornwall; Ilfracombe, Watermouth, and near Binham, Devonshire; rocks at Dunraven, Port King, and Barry Island, Glamorganshire ; Glen Meay, Isle of Man; South Isles of Arran; Cahir Couree Mountain, near Tralee, and the Banks of Lough Bulard, near Urrisbeg, Ireland.

Perennial ; in perfection in July. 
The drawing of our specimen is made one half the natural size. The fig. $a$ is a detached pinnule, and is drawn the full size, showing the mode of the distribution of the veins and form of the indusium over the sori. Fig. $b$ is the indusium turned back, to show the position of the sori in a young state, and the termination of the veins : this is greatly magnified. Fig. $c$ is one of the thecæ removed, and greatly magnified, to show its structure and its minute globose or ovate smooth sporules.

This is one of our most beautiful and elegant Ferns, is most constant in its form, and most delicately constructed, forming when it grows abundantly a gay living mantle, gracefully drooping over time's destructive march upon old walls or crumbling rocks. It is exceedingly common in the South of Europe, triumphing over and throwing its slender form in glowing tapestry equally over the mouldering remnants of the splendid Pagan temple, and the vast remains of Roman luxury, or the ruined tomb; but nowhere is it seen in greater beauty, or more majestically drooping, than in that enchanted Grotto, where the ancient Romans, according to the story of Ovid, represented that Egeria was su disconsolate at the death of Numa, that she melted into tears, and was changed into a fountain by Diana, and here

\footnotetext{
6. The mosses of the fountain still are sprinkled With thine Elysian water-drops; the face Of the care-guarded spring, with years unwrinkled, Reflects the meek-eyed genius of the place, Whose green, wild margin now no more erase Art's works ; nor must the delicate water's sleep Prison'd in marble, bubbling from the base Of the cleft statue, with a gentle leap The rill runs $o^{\prime} e r$, and round fern, flowers, and ivy creep Fantastically tangled."
}

The fronds of the Maiden-hair are used in the South of Europe for making a kind of syrup, which is sold in the shops under the name of Syrup of Capillaire, and is thought useful as a diuretic ; and for the relief of coughs, it is also used in the form of tea, and makes a pleasant drink in cases of fever, \&c.; according to Mr. Ball, the inhabitants of the South Isle of Arran use the fronds in the place of tea. 


\section{GENUS VIII. LOMA'RIA.-WILLD. Lomaria, or Hard-fern.}

Gen. Char. Sori in a continuous line on each side of the mid-rib, covered by a continuous indusium, the lateral veins not extending beyond the indusium.-Name from $\lambda \omega \mu \alpha$, an edge; in allusicn to the incurved margin forming the indusium.

1. L. spi'cant, Desveux. (Fig, 1587.) Hard-fern. Fronds linear lanceolate, pectenato-pinnatifid, the segments of the barren fronds linear oblong, acute, of the fertile, narrow, linear, acute.

Newman's British Ferns, p. 89.-Blechnum boreale, Linn.-English Botany, t. 1159.-English Flora, vol. iv. p. 303.-Hooker, British Flora, ed. 4. vol. i. p. 389.

Root stout branched wiry fibres. Rhizoma short, thick, tufted, scaly. Fronds numerous, erect, linear lanceolate, tapering, dark green, smooth and shining above, paler and dull beneath, pectenatopinnatifid. The rachis simple, naked, and of a dark purplish colour below, and somowhat scaly, the scales thin, brown, membranous, barren fronds with oblong acute alternate segments, often opposite in

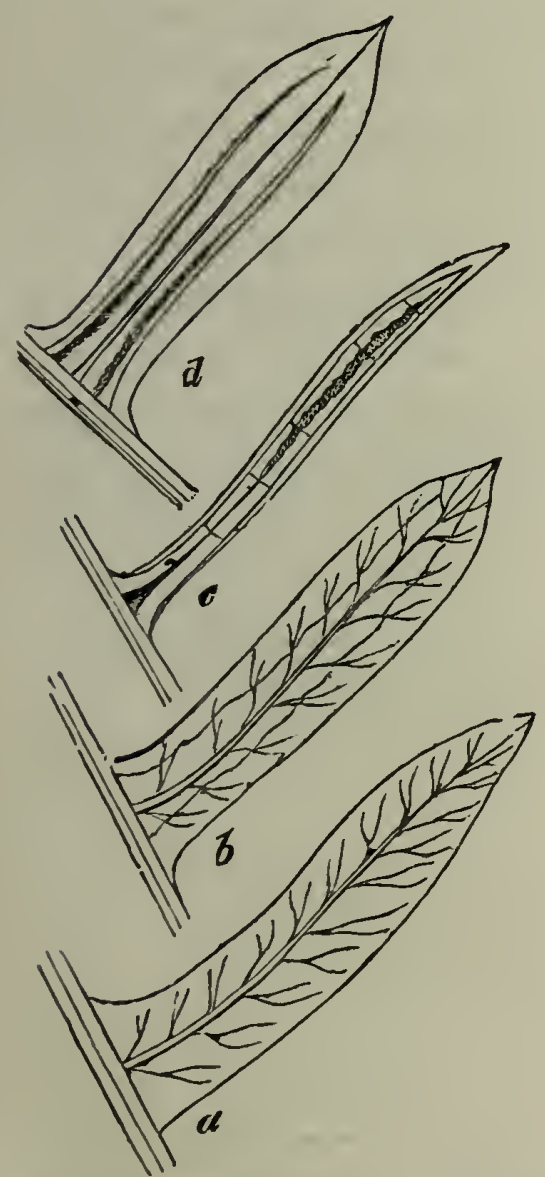
the lower part, somewhat curved up. wards, slightly reflexed on the margin, the mid-rib prominent, the lateral veins slender, bifurcated, and terminating before reaching the margin, fertile fronds with narrower, more linear segments, the lateral veins (fig. b) in the annexed sketch are disposed in the same way as the barren ones (fig. a), but with an additional vein communicating from one to the other at the joints, and running the whole length of the pinnæ, and from these arise the theco in a continuous line, as seen in (fig. $d$ ). The thecæ, as they are developed upon the inner side of the vein, push up the cuticle of the pinnæ into a ridge, which bursts on the inner margin, and $f_{\text {orms the indusium, which splits at }}$ intervals; where the lateral veins haje arisen by this process, the pinnæ are contracted into their 
narrow form (fig. $c$ ), which before the formation of the thecæ was as broad as the barren ones, which will be seen by the illustrations

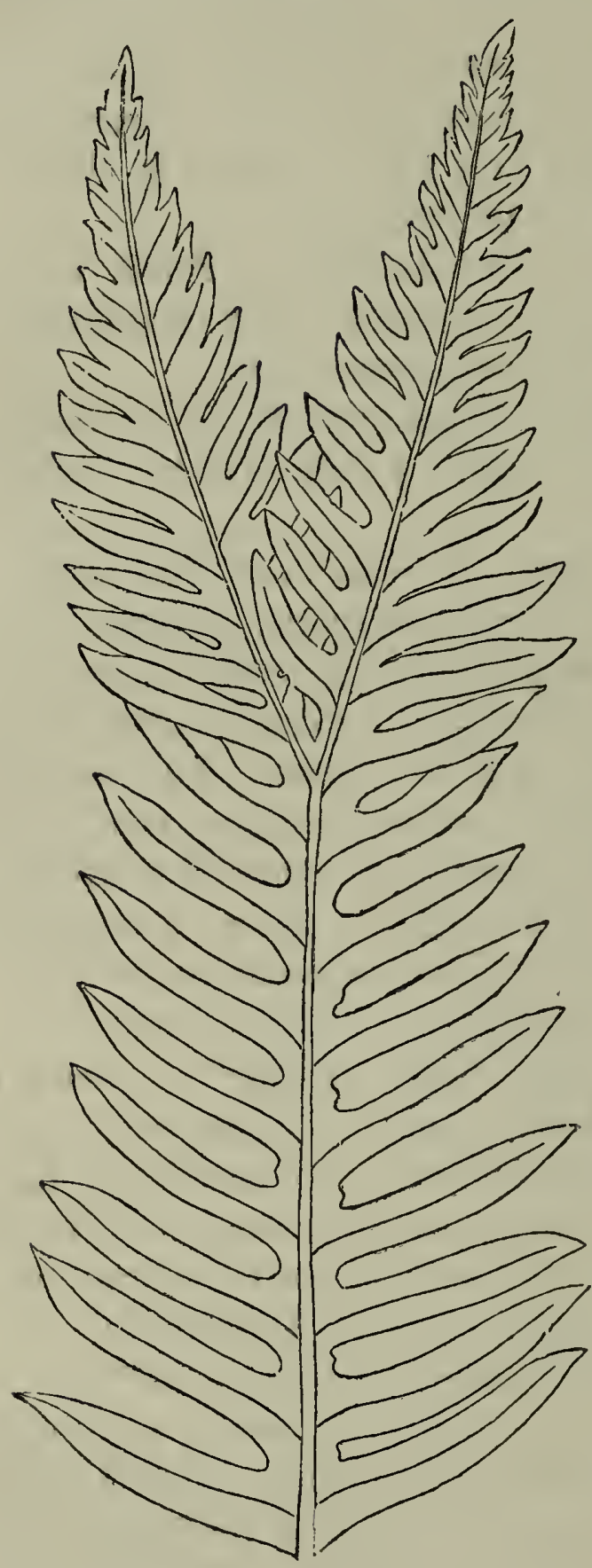
$a, b, c$, and $d$. As the thecæ advance to maturity, they are pushed from under the indusium, and form a crowded dark brown or blackish mass. Thece small, globose, encircled by a beaded elastic ring, of a crimson colour. Sporules ovate, smooth.

Habitat.-Woods and heathy places; common.

Perennial; in perfection in August and September.

The drawing of this plant is made about one-third the natural size. The thecæ and sporules are highly magnified. This fern is, perhaps, the least liable of any of our species to vary in its form. The bifid barren frond, which the accompanying sketch,made the natural size of the plant illustrates, is the only remark. able one we have seen, and for it we are indebted to Mr. G. Ridge. It is a very generally distributed plant, and extremely hardy.

GENUS IX. PTE'RIS.-LINN. Common Brakes.

Gen. Char. Sori continuous, linear, marginal, covered by a continuous marginal indusium. -Name $\pi \tau \varepsilon \xi b$, in Greek a fern, from 
$\pi \tau \xi \rho \nu \xi$, a plume or feather; in allusion to the elegant plumed appearance of some of the species.

1. P. aquili'na, Linn. (Fig. 1588.) Common Brakes. Fronds triangular, tri-partite; branches bi-pinnate; pinnules cleft to the mid.rib; the lobes oblong, obtuse, entire; the margin reflexed.

English Botany, t. 1679.-English Flora, vol. iv. p. 305.-Hooker, British Flora, ed. 4. vol. i. p. 389.-Newman's British Ferns, p. 99.

Roots fibrous, brown, and tomentose. Rhizoma dark brown or black, more or less clothed with soft velvety pubescence, and extensively creeping both in an horizontal and perpendicular direction, often forming matted masses beneath the soil. Fronds erect, from one to ten feet high; when grown in an open situation it is in form a nearly equilateral triangle, but when grown in a moist and shady place it becomes more elongated. The young fronds are extremely brittle, and push themselves out of the soil, doubled down with the leafy portion pressed next the stem, as seen in our plate, and gradually rise and expand themselves as there shown. The stem, from its attachment to the rhizoma to its first division of the frond, is about half its whole length; it is dark brown, and pilous-like. The rhizoma at the base, and a little above its insertion, is swollen: if transverse sections of the stem are made, it will be seen that the dark cellular and fibrous masses represent figures which resemble an "Oak Tree," or, as some say, a "Spread Eagle;" hence it has its specific name of Aquilina. We have carefully represented sections made in different parts of the stem. Fig. $a$ is the upper, $b$ the

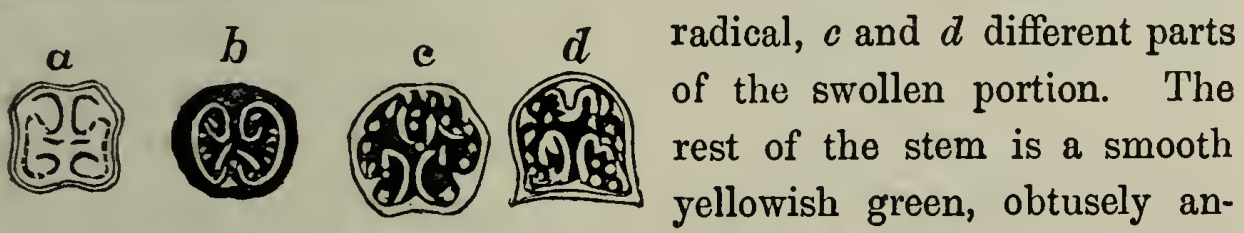
gular, sometimes scattered over with brownish scales. The frond is repeatedly three branched, a smooth dark green above, paler beneath, and hairy, especially along the mid-ribs. The pinnce are lanceolate pinnate, the piunules pinnatifid. Fig. $e$, given in page 55 , is here drawn the natural size, the lobes are oblong, obtuse, entire, waved or lobed, as in fig. $f$, page 54 , or the whole of the lobes curled and waved, as in fig. $g$, page 54, giving it crisped appearance; each lobe has a prominent waved mid-rib, with alternate lateral veins, each of which is twice branched in a dichotomose manner, and terminates in the margin, from whence arise the thecæ (fig. $h$, page 55), which are drawn larger than natural, to show the veins and the margin, folded over in the form of a thin transpa- 
rent membrane, and covering the thecæ in the form of an indusium. When this membrane is highly magnified, it is seen (as represented in fig. $i$, page 55,) beautifully traced over with tortuous semi-trans. parent veins, and the margin furnished with jointed hairs, which are in reality formed of elongated cells, placed in contact one upon the end of another, as seen in fig. $j$, page 55 . The membrane on the upper surface of the frond, if removed and placed under a magnifying power, will be seen to resemble fig. $i$, page 55 ; but if a portion of the

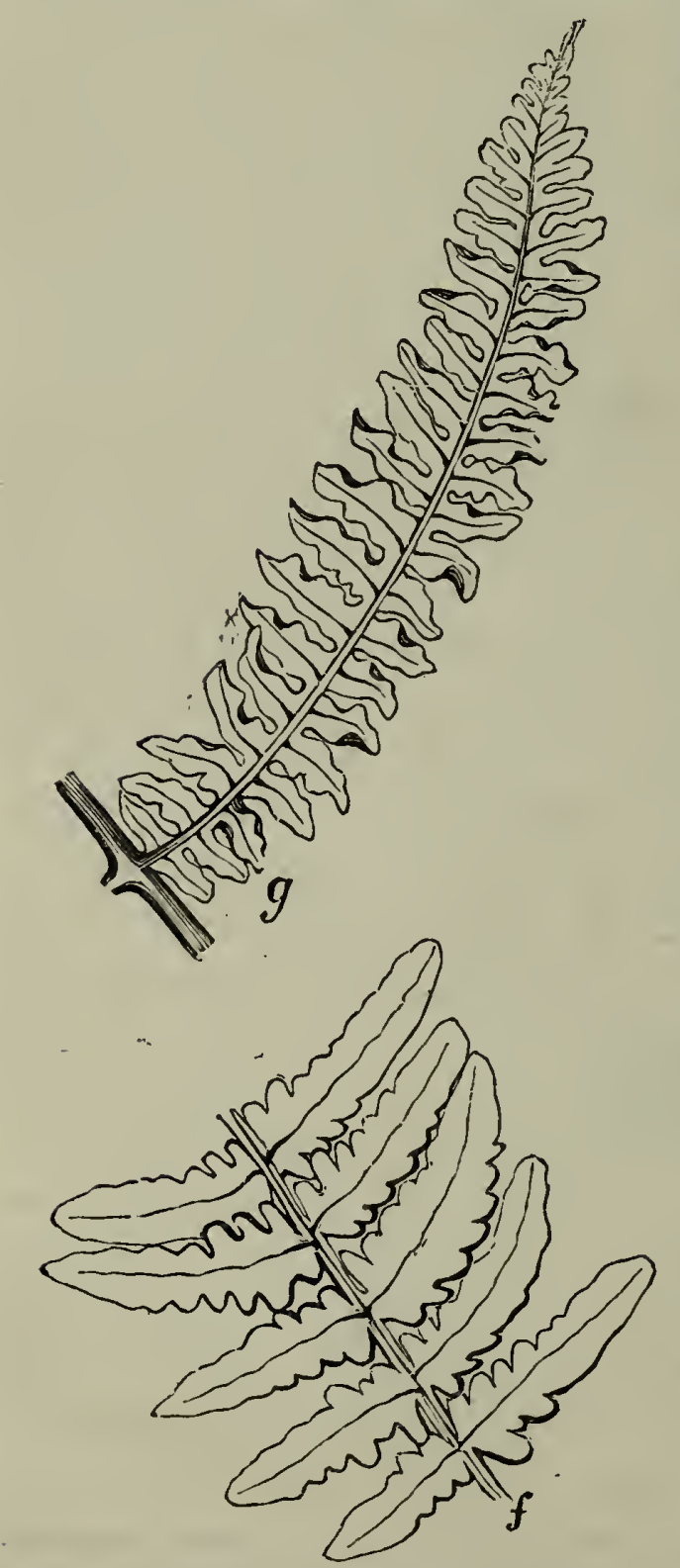

membrane on the under surface be treated in the same way, it will be found to resemble fig. $k$, while thickly interspersed amongst its cells are

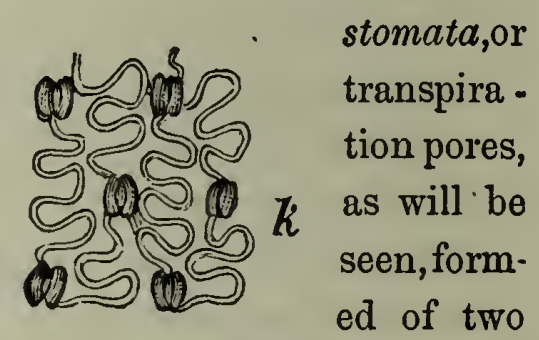

kidney-shaped cells, which by their contraction and expansion, according to the different states of the atmosphere, l'egulate the temperature, and the egress or ingress of air through these pores. This beautiful arrangement of the parts of the plant here described, is not peculiar to this species, but is similar in all the other, and is here given to point out to the student the fund of amusement and in. terest which is in store for those who will examine for themselves any of the won. derful works of creation. Fig. $l$, page 55 , is a pinna, drawn the natural size, and exhibits the under side, as it is seen, crowded with thece, in linear sori along the margin, and under the marginal membrane, more distinctly seen in fig. $h$, but there represented without thecæ. If these thecæ are removed, there will be found 
another thin membranous prolongation on the under side, so that the thecæ are between two membranous elongations, as seen in fig. $m$,

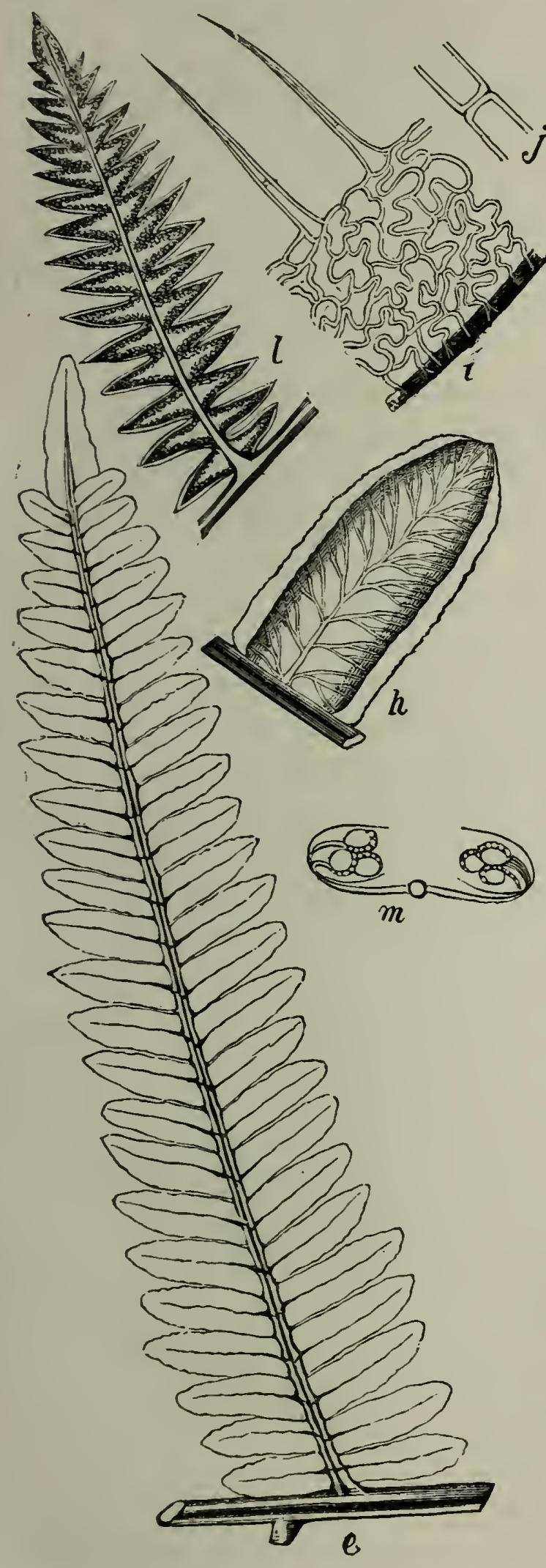
which is a transverse sec. tion of one of the lobes; the upper line is the prolongation of the margin turned over, and covering the thecæ, which are seen to arise from the margin of the frond, where the la. teral veins terminate, and beneath them is another prolongation of membrane, very thin and transparent; which of these is the proper indusium is a question not yet determined: we have continued to call the upper one the indusium, until further researches in these organs enable us to more clearly define which is the proper one. The theca are numerous, globose, and encircled with a beaded elastic ring. The sporules are numerous, angular, ovate, and roughish.

Habitat.-Heaths, woods, \&c.; very common.

Perennial; in perfection in August.

This is the commonest and most abundant of all our Ferns, andis known by the name of Brakes, or Bracken. It will grow in all kinds of soil and situation, however open or exposed, or in the close wood or forest, but it is one of the plants most 
easy of extirpation, and one of the most useful. From the wide distribution of its places of growth, it is, as might be supposed, extremely variable in the size it attains, for in cold bleak situations with a clayey soil it is not more than a foot high, while in a vegetable mould in woods and shady places it grows to the height of ten or twelve feet, or even more ; in the former instance it is an almost equilateral triangle in outline, in the latter it is very much more elongated. The rhizomas are numerous, strong, and extend a considerable distance perpendicularly, horizontally, or otherwise, and are extremely useful when dead, as forming a kind of tube by their outer fibrous coating, which remains some time after the inner cellular substance has perished, and thus providing for the conveyance of rain as it falls into the ground, instead of its running off the surface: this use of the plant is very great in hard clayey soils, \&c. The green fronds, when cut, are used as litter for horses, cows, \&c., and from the great quantity of alkaline salt in their composition, form the best kind of manure, and even when cut and left to rot. Bracken, according to Lightfoot, is a great improver of the land. Such is the quantity of alkali which it contains, that the same author tells us that in many of the Western Isles of Scotland, the people gain a considerable profit by the sale of the ashes to soap and glass-makers; and in Wales, as is related by Mr. Blagdon, in Magazine of Natural History, "the plant, when it has been well dried, is burned by the cottagers in large heaps, for the sake of the alkali contained in the ashes; when sufficiently burned, enough water is sprinkled on the ashes to make them adhere together, when they are rolled into round balls about two inches or two and a half in diameter. These balls are thoroughly dried and carried about the neighbourhood where they are made, for sale in the markets; and they are also frequently kept by shopkeepers, to supply their customers. The price of these balls varies in different seasons, from $3 \mathrm{~d}$. to $8 \mathrm{~d}$. per dozen. They are very much prized by some housewives for their utility in the wash-house in economising the use of soap. When about to be used they are put into the fire, and when heated to red heat, are taken out and thrown into a tub of water; the water, in the course of an hour or so, becomes a strong ley, and is then fit for use." It is used, especially in Scotland, as a thatch for cottages; and the young tender fronds, before they are expauded, prized as food for pigs They are gathered into bundles, and boiled in water, the thick mucilaginous fluid thus produced being mixed with their other food, is thought to be very nutricious; but in Normandy, we are told by 

Lightfoot, it has been used by the poorer inhabitants as an article of food, by mixing the larger rhizomas with their bread in times of great scarcity; and it is said that in Siberia, and some other northern c suntries, the inhabitants brew the rhizoma in their ale, using onethird to two-thirds of malt.

As a medicinal plant it was formerly much prized; both the fronds and succulent rhizomas were used in decoctions and diet drinks, in chronic disorders of whatever kind they might be, but especially those arising from "obstructions of the viscera and spleen." It was hardly less esteemed as a remedy for the cure of worms ; and it is still retained in the Materia Medica for the same use, especially for the removal of the tapeworm. The dose of the powdered rhizoma is from one to three drachms; and this repeated for several mornings, and afterwards followed up with a brisk purgative, is said to have been useful when all other means have failed. M. Pescher, of Geneva, submitted the rhizomas to the action of Sulphuric Fither, and obtained oily resinous substance, being the active principle, which he has found in the dose of from eight to thirty drops, administered made up into pills, or mixed with syrup, one half at bed time, and the remainder the following morning, to be most successful in removing (tenia) tapeworm, especially if it is taken when the stomach and bowels are empty, and followed by a brisk purgative.

The dried fronds are stacked and kept in store as bedding for cattle and horses, and are much used as a material for packing goods instead of straw, for which purpose they are better for many kinds of goods, as being more elastic and softer. The stems and rhizomas are used, from the quantity of tanning and astringent matter which they contain for tanning kid and chamois leather.

\section{GENUS X. ASPLE'NIUM.-Lins. spleenwort.}

GFN. Char. Sori oblong, or linear. Indusium of the same shape, arising from the lateral veins, and opening on one side longitudinally towards the mid-rib. -Name from $\alpha$, not; and $\sigma \pi \lambda n \nu$, the spleen; so called in allusion to the plant being used in affections of the spleen.

1. A. Filix-fe'mina, Hook. (Fig. 1589.) Lady-fern. Frond broadly lanceolate, acuminate, pinnate; pinnæ linear lanceolate; pinnules oblong lanceolate, inciso-serrated, with acute teeth; lateral veins 
branched, the anterior branch with the mid-rib bearing the linear sori ; indusium with a waved fringed margin.

Hooker, British Flora, ed. 4. vol.i. p. 388.-Aspidium.-English Botany, t. 1459.-English Flora, vol. iv. p. 282.-Athyrium, Presl.Newman's British Ferns, p. 237.

Roots long, fibrous, wiry, black. Rhizoma large, thick tufted, often elevated several inches above the surface of the ground. Fronds in vernation are curled up in a most beautiful and elegant manner, with the foliaceous portion next the stem, becoming as they attain to the full size most graceful, expanding their delicate divided forms, gently drooping into a broadly lanceolate figure, mostly tapering at the point, and attaining a length varying from one to six feet, regularly
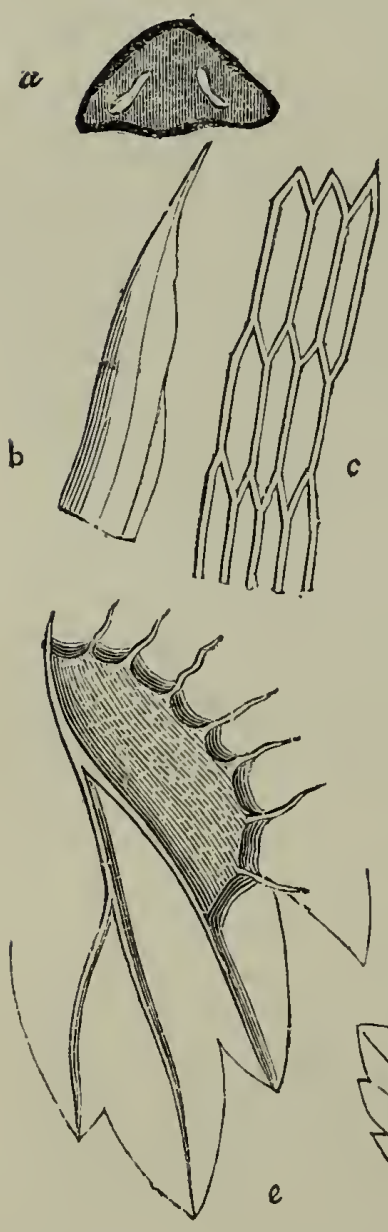
pinnate, with the pinnce opposite and alternate, of a linear lanceolate shape, pinnated, the pinnules are oblong, obtuse, or acutely serrated, or cut in a pinnatifid manner; the lower naked portion of the stem varies from one-third to a quarter of the whole length of the frond, is much swollen near the base, of an unequally triangular form, and when divided transversely, is seen as in the accompanying fig. $a$. The two bands seen in the midst of cellular substance being bundles of ducts, which convey

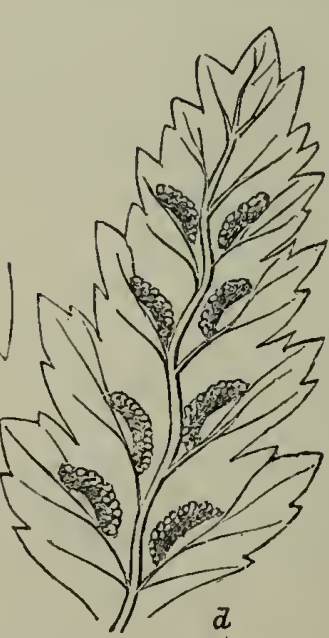
the sap from the mid-ribs and veins of the pinnæ, to form the proper juices of the plant. The lower portion of the stem is mostly thickly clothed with thin membranous scales, of a lanceolate form (fig. $b$ ), which are seen when highly magnified to consist of cellular substance, more or less elongated, (fig c). The whole of the rachis is scat. tered over with these scales, but in the upper part they are smaller, and more attenuated in their form. The pinnules (fig. $d$ ) are distinctly marked with a waved mid-rib, and alternate or opposite lateral veins, which terminate in the point of the teeth; each lateral vein is branched, and from the uppor edge of the mid-vein and its branch nearest the mid-rib arise 
the sori. The involucre (fig.e), which is pale, thin, and membranous, is of a linear or ovate kidney-shape, fringed with capillary segments, which, as the thecæ are developed, become rounded, or irregular in form, and sometimes, though rarely, the sori become confluent. Theca pale brown, globose, with a beaded elastic ring. Sporules very minute, ovate.

Habitat.-Moist shady places; frequent.

Perennial ; in perfection in June and July.

This generally distributed fern is subject to considerable variation in size, and the more or less deeply cutting of its lobes, from which circumstance it has given rise to a belief of the existence of several species. Roth divides them into the five following species, which we retain as varieties, from a fact that our observation has not led us to regard those characters as sufficiently distinct or constant to constitute them species, and, indeed, we have much hesitation in retaining either trifidum or ovatum eren as varieties sufficiently distinct from molle.

1. Molle. Frond small, ovate lanceo late, pinnate; pinnæ pinnate (fig. $f)$, their mid-rib winged, the lower pair distant from the rest, short, deltoid, deflexed; pinnules flat, ovate, decurrent, toothed, with short acuminate teeth; the clusters of capsules are very distant, there are five to seren pairs on a pinna.Athyrium molle, Roth.-A. Filixfemina, var. molle.-Newman's British Ferns, p. 242.

2. Trifidum. Frond as large again as the above, the pinnæ pinnate (fig. $g$, page 60,) the pinnules flat, semi-decurrent, not being quite united by a ring of the mid-rib, more deeply cut, and the end of the lobes three toothed, the teeth acuminate, and somewhat inflexed. The first anterior lobe of each pinnule is larger than the rest. The clusters of thecæ are smaller and more remote than those of var. molle.-Athyrium trifidum, Roth.-A. Filix femina, var. trifidum.-Nowman's British Ferns, p. 242. 
3. Ovatum. This is an intermediate variety between the two former; its size and form resemble that of molle, but the cutting of the lobes that of trifidum. It is, however, of a darker colour, and more robust in its structure, the stem and ribs more scaly; the upper pinnules are winged, but the lower are not so, and their lobes are broadly oblong, obtuse, the

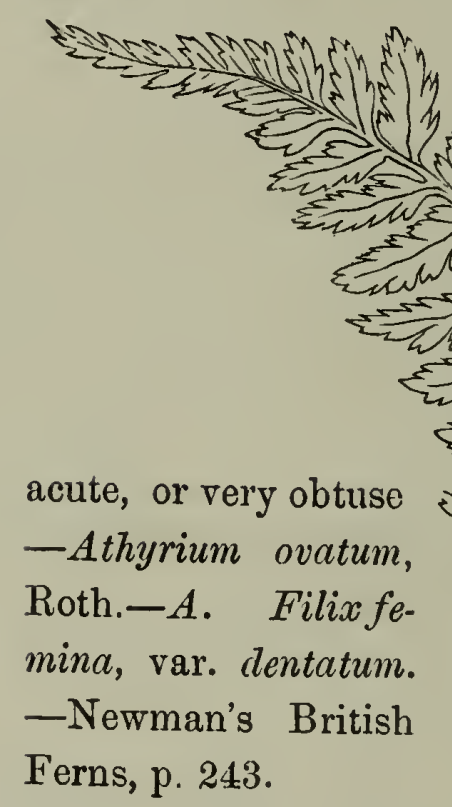

4. Incisum. This is the largest of the varieties growing from four to six feet long, and from twelve to eighteen inches wide, of a dark dull green colour; the pinnæ are pinnate (fig. $h$, page 61 ,) from six to nine inches long, and the pinnules are margins have one or two teeth on each side, and are terminated by three or two others ; the teeth are ovate, sometimes almost quite pinnate, flat, the teeth lanceolate; sori numerous often scattered irregularly, especially on the basal lobes.-Athyrium Filix-femina, Roth.-A. Filix-femina, var. incisum.-Newman's British Ferns, p. 243.

5. Rhaticum. Frond with a short stalk, and but few slender brown scales, a pale yellowish green colour, of a linear lanceolate form ; the pinnæ pinnate (fig. $i$, page 61 ); the pinnules narrow, linear, from the circumstance of the teeth being curved inwards over the sori, instead of being flut, as are those of the other varieties; the sori are numerous, crowded, becoming confluent. -Athyrium rhaticum, Roth.-A Felix femina, var.convexu.m.- 


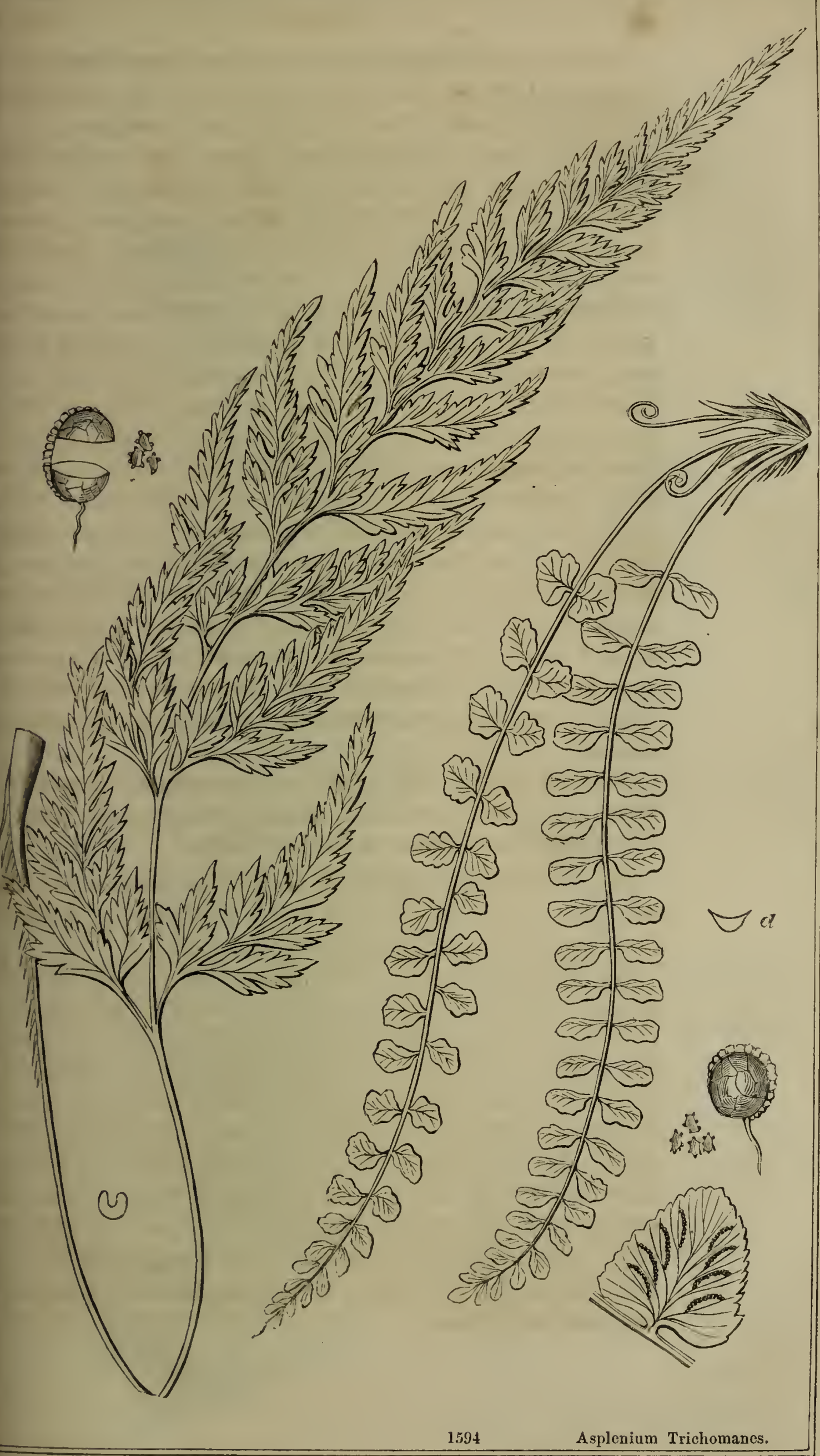




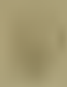

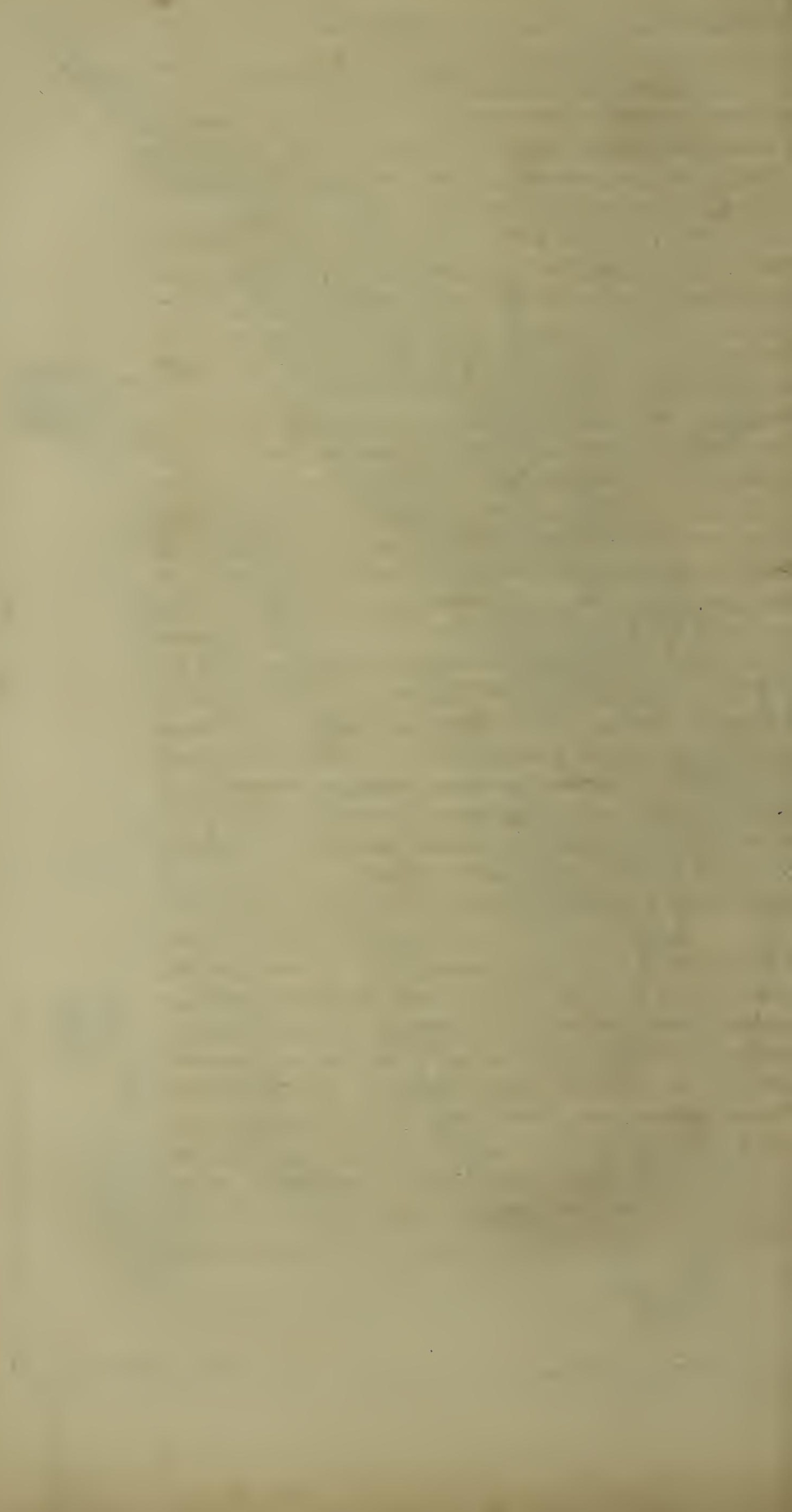




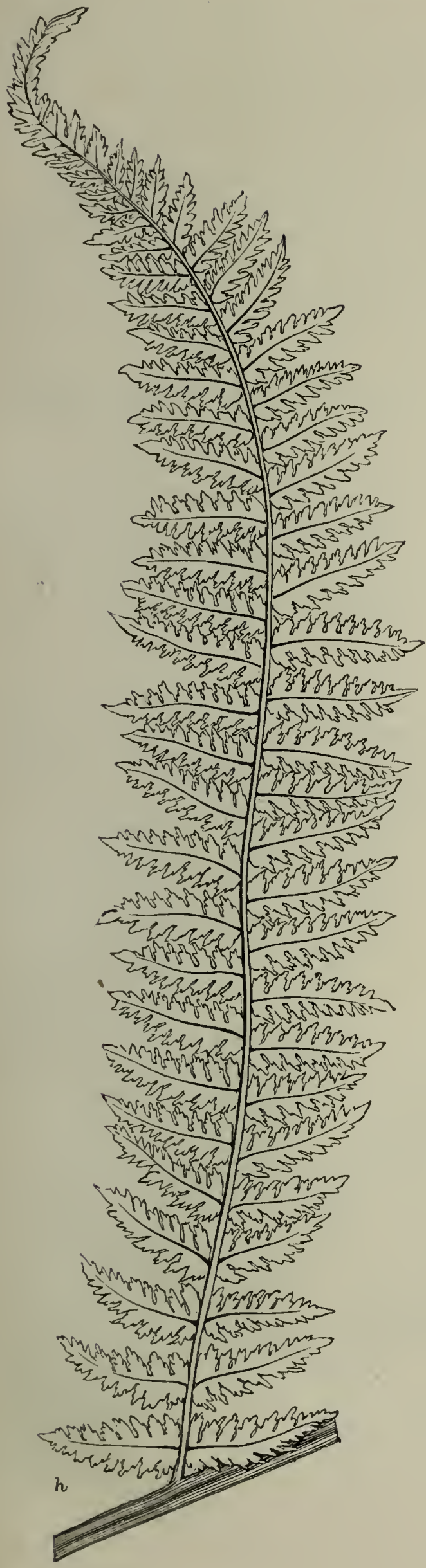

Newman's British Ferns, p. 245.-Aspidium irriguum.-English Botany, t. 2199. (a starved va. riety.)

The varieties, molle, trifidum, and ovatum, are found in

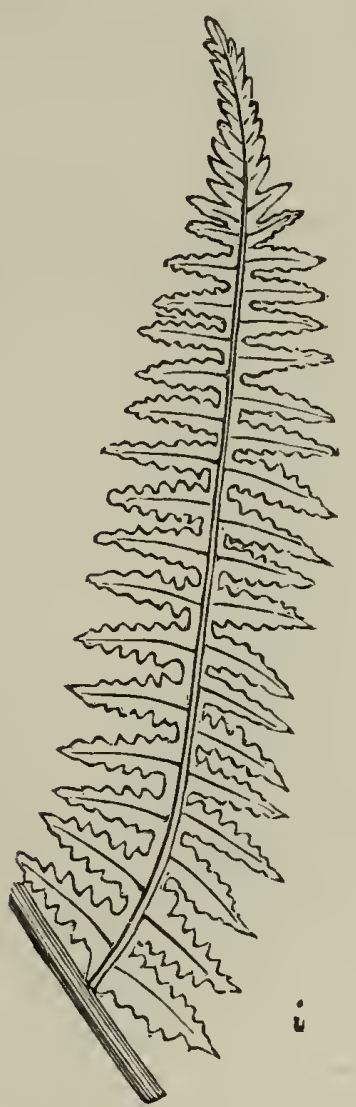

damp situations. By the side of streams is their favourite locality, where they are partly shaded, incisum luxuriates in a dryer lighter soil, and rhaticum in stony places. Though these are the most distinctively marked varieties, so cleverly pointed out by Roth, still we are constantly finding variations from these, so that it seems impossible to say with certainty under which of them they ought to be placed, and uniting them one to the other, as it were, link by link 
in a chain, so slightly differing one from the other, or one partaking of the characters of the one and the other another; and it is only in extreme variations in their forms that the student seems to be able to

A. fontanum, Br. Smooth Rock Spleenwort. Frond linear lanceolate, or oblong lanceolate, bi.pinnate; pinne shorter and more distant towards the base, shorter and more crowded towards the point, oblong, pinnate; pinnules oblong, or roundish ovate, toothed, with angular sharp spinous teeth; lateral veins simple or branched, terminating in the points; indusium half ovate, entire.

A. Halleri, Brown.-Aspidium.-English Botany, t. 2021.-English Flora, vol. iv. p. 209.-Hooker, British Flora, ed. 4. vol. i. p. 388.-Athyrium, Roth.-Balbington's Manual, p. 388.

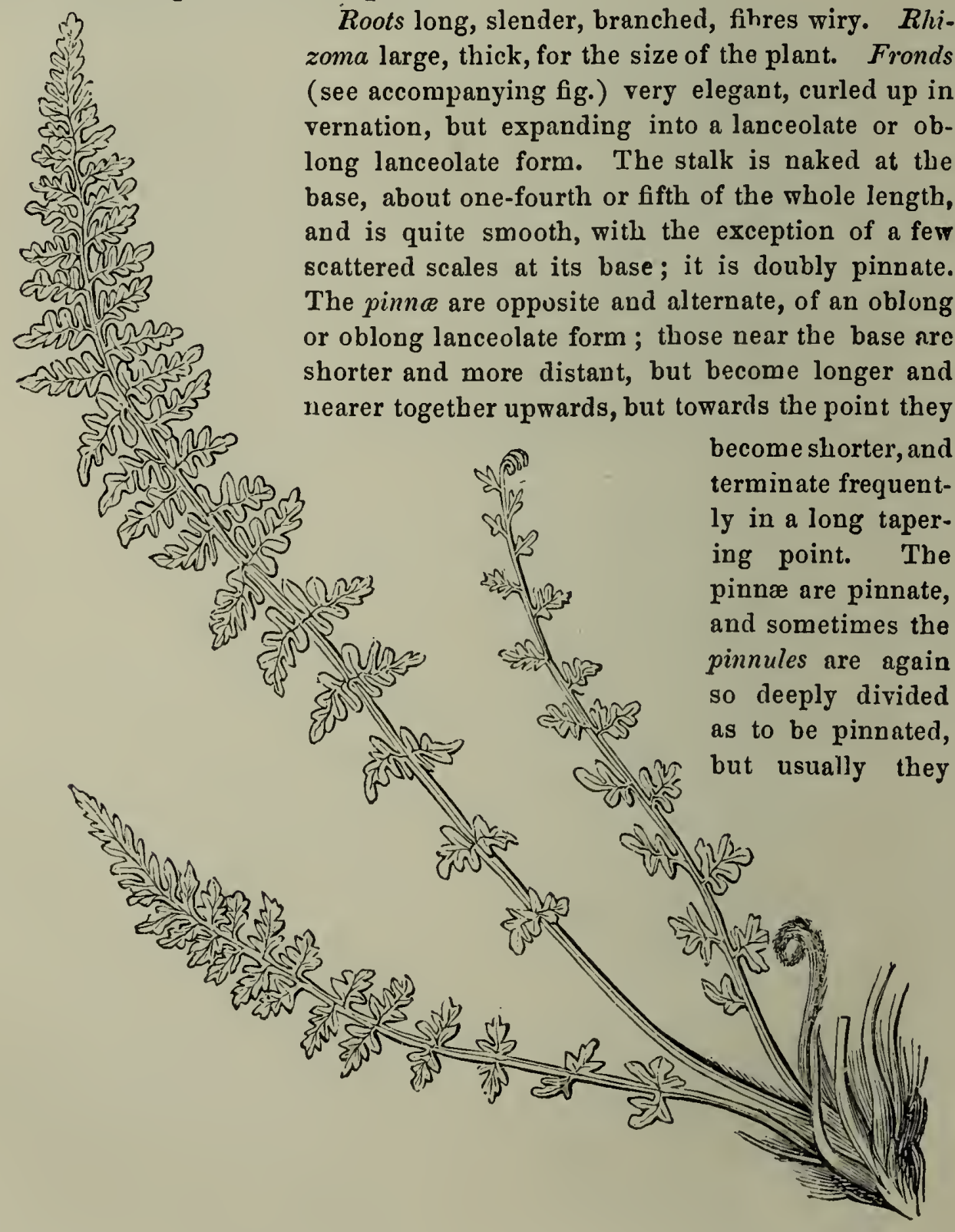


reposo with confidence as to his plant being different from the one or other.

This, the most elegant and delicately graceful fern, takes the first rank in beauty amongst our native species, whether as an adornment to our woods, or nestling on the banks of hedges, or gracefully drooping on the torrent's side or by ripling mountain streams. Its tufts of fronds, whether when young, and putiing forth its delicate and tender frond in its closely curled up form, or when more expanded into its pastoral hook-like shape, or fully spread forth in its matured state, must be appreciated for its loveliness. It forms an admirable cover for rabbits, hares, and birds of various kinds, and is used for the purpose of packing fish for transportation from the sea coast to inland markets.

To illustrate with drawings on a small scale this species, and to give an idea of its elegance and beauty, seems almost impossible. The frond represented in our plate (fig. 1589) is one-tenth the natural size. The thecæ are highly magnified, to show their structure, as are

are as representated in the pinna (fig. a), toothed, with angular sharp pointed teeth, each tooth having a branch of the lateral vein terminating in

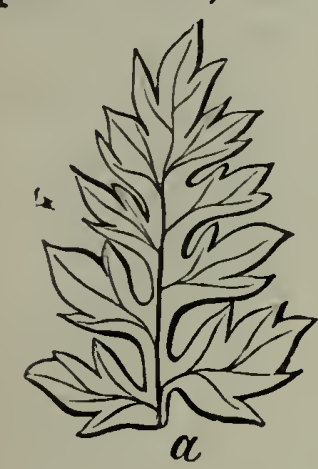
its apex, which in a young state is often strongly curved, almost hooked. The mid.rib is waved; the superior pinnule of each pinnæ next the rachis is often larger than the others, though this is not constant, and, indeed, fronds from the same rhizoma are different; some having this enlarged lobe, others not; and we observe that it is largest in the strongest and most robust fronds. Indusium half ovate, entire on the free edge, and always attached to the margin of the vein nearest to the mid-vein: if they arise from the lateral vein they burst towards the mid-rib, if from the branches

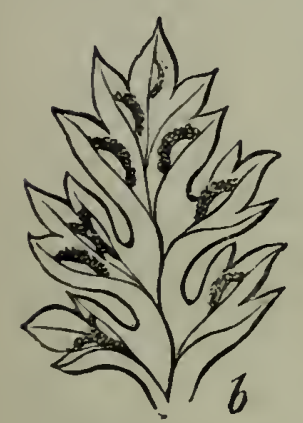
towards the lateral vein, as seen (fig. $b$ ). The sori at first are small, but soon become large, and confluent, thickly covering the entire pinna with the bright brown thecæ, and destroying the indusium. The thece are small, globose, with an elastic beaded ring. The sporules nu. merous, angular, and rough.

Habitat,-Formerly on Amersham Church, Bucks, and said to have been found by Hudson in Cumberland and Westmoreland.

Perennial; in fruit in September.

British specimens of this beantiful fern we have not seen, but have found it not unfrequent on limestone rocks in Switzerland, and from these our drawing has been made. It generally grows among loose rocks in large 
also the unequally ovate sporules. The pinnæ, $f, g, h$, and $i$, are drawn the natural size; but the pinnules, $d$ and $e$, are magnified, to show the distribution of the veins, the situation of the sori, and the form and structure of the involucre, with its fringed margin.

Some very curious formed specimens of this species are occasionally found, which are interesting, however, only for their monstrosity or deformity, and remarkable as retaining their distorted form under cultivation.

2. A. Adian'tum-nigrum, Linn. (Fig. 1590.) Black stalked Spleen. wort. Fronds triangular, attenuated, tri-pinnated below; pinnæ alternate, arising obliquely from the rachis, triangular, attenuated; pinnules ovate lancenlate, inciso-pinnatifid, and toothed; rachis above winged; lateral veins branched, and terminating in a club-shaped point before reaching the margin; sori central ; indusium linear, with a straight entire margin.

English Botany, t. 1950.-English Flora, vol. iv. p. 297.-Hooker, British Flora, ed. 4. vol. i. p. 388.-Newman's British Ferns.

Roots fibrous, long, tough, black, wiry. Rhizoma tufted, black, and scaly. Fronds curled up in vernation, and as they expand are for a time erect, but soon become drooping, and generally when matured pendulous. The stem is a dark purplish or black colour, very smooth and shining, deeply channeled on the upper side, rounded at the back, thickened or compressed at the base, and the lower part more or less clothed with narrow brown scales. The form of the frond is triangular, the two lower pinnæ being longer than the others, which gradually diminish upwards into the long attenuated point; it is of a dark shining green above, paler beneath, pinnate, the pinnæ (fig. $a$ and $b$, page 65) arising obliquely from the stem alternately, are triangular, with an attenuated point, and pinnate; the pinnules also arise obliquely and alternately, and are themselves pinnated.

tufts, where it is somewhat protected, and varies in length from three to twelve inches, but in all its forms, as far as we have seen, its characters are too well defined to be likely to mislead the student. Our illustration is made the natural size of an ordinary grown plant, but the pinnules are magnified to show the distribution of the/ veins and sori. We retain this in a note to our Flora, being doubtful whether it ought to be considered a native species or not. The habit of the plant and its general aspect is that of Woodsia, from which, however, there is no difficulty in distinguishing it. 
The lobes (fig. c) themselves are also often, and especially the lower ones deeply cut in a pinnatifid manner, but usually only cut

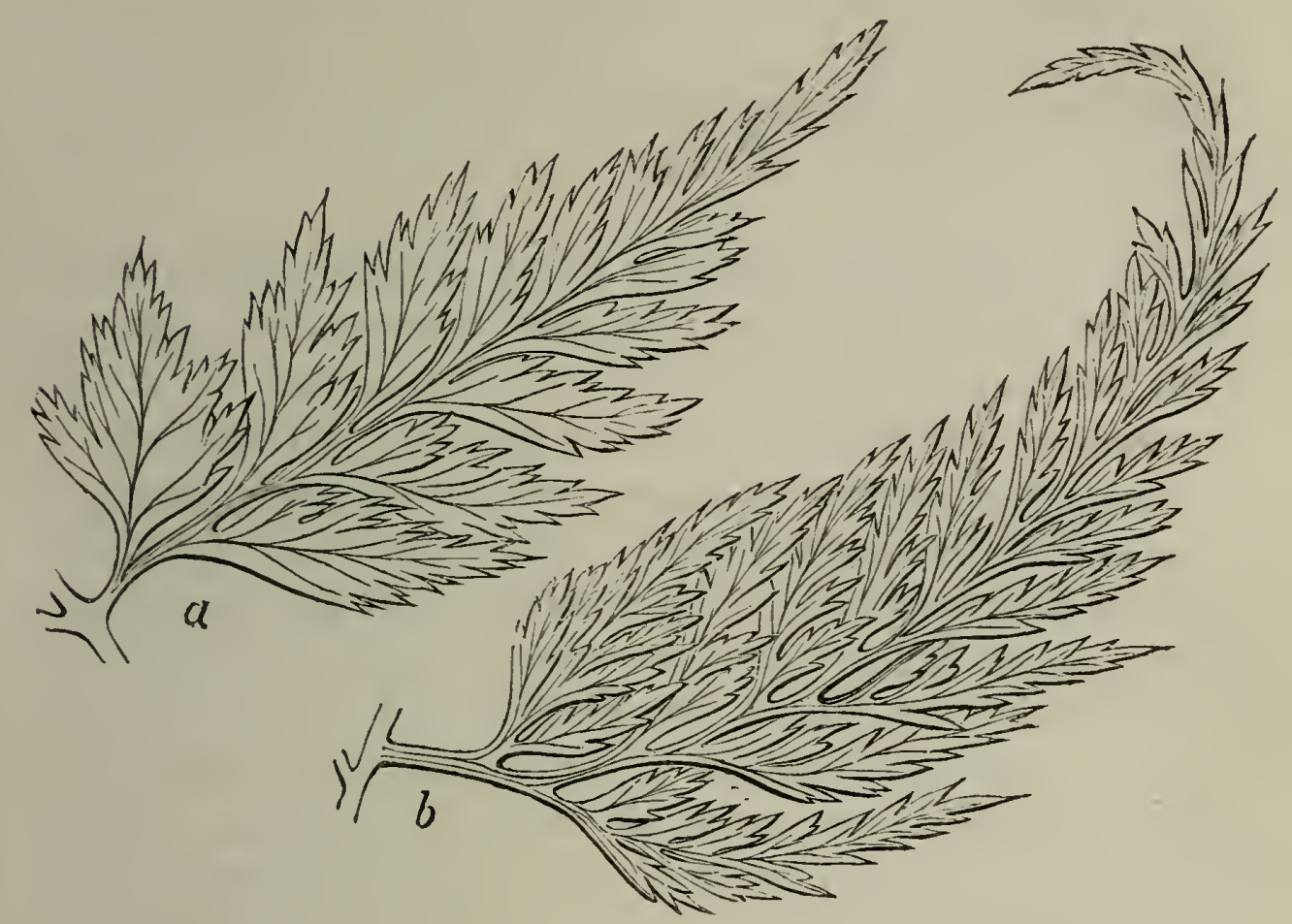

and strongly and acutely serrated. The mid-rib of the pinnules is prominent, waved, as well as of the lobes; the lateral veins arise alternately, and terminate each below the point of the teeth in a club-shape, (fig. $d$ highly magnified), or obtusely, nearly every one of which bear on the margin towards the mid-rib, and near its junction a linear sorus (fig. c), the indusium of which is narrow, linear (fig. $d$ highly magnified), pale and entire on the margin. As the thecr expand, the sori become confluent, push-

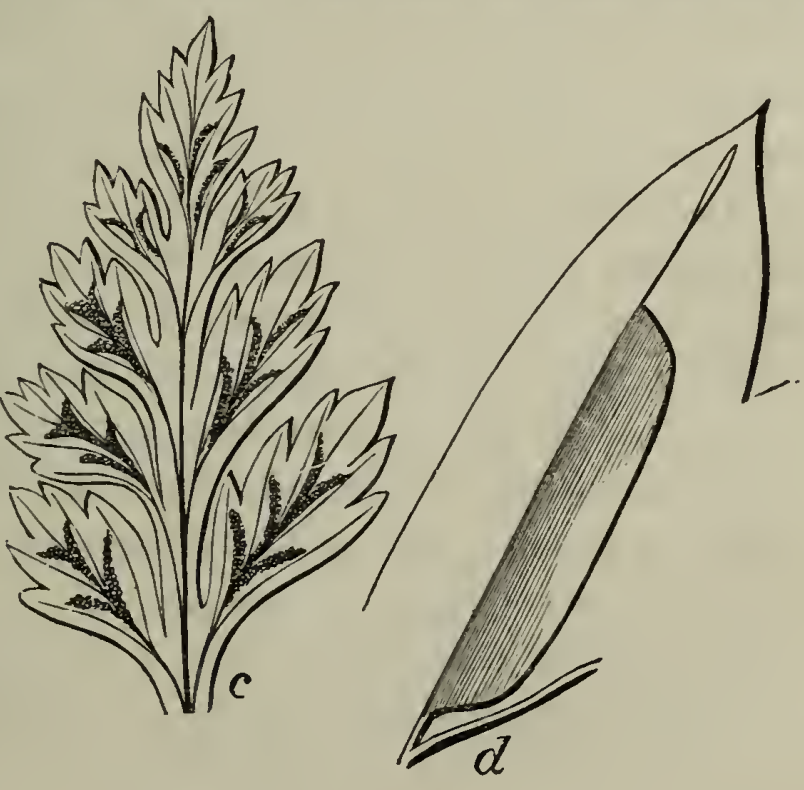
ing away and destroying the indusium, and entirely covering the pinnules with their brown masses. The theca arise from the lateral veins, and are attached by a 
cellular pedicel, which becomes elongated; they are globose, shining brown, and burst open by the expansion of the beaded elastic ring, by which each is nearly encircled. The sporules are numerous, ovate, angular, and roughish.

Habitat.-Banks, fissures of rocks and walls ; common.

Perennial; in perfection in August and September.

Our plate (Fig. 1590) illustrative of this species is drawn of the natural size, and is the common form and size usually found growing on dry banks and walls, or the shady part of rocks, and the variety officinarum of Newman; but a plant so generally distributed as this is, and capable of growing under almost every variety of exposure or soil, is, as might be supposed, very variable in its size and form, and to describe each variation would be as tedious as we presume it would be unprofitable. We have given in our marginal fig. $a$ the first pinna of a frond, drawn the natural size, which we give as an example of one of the most undivided form of fronds, when it is the Asplenium obtusum, Willdenow; the variety obtusum Newman. Fig. $b$ is also the first pinna of a frond, having the pinnules and lobes very narrow, more deeply cut, and the teeth more slender; this is the Asplenium acutum, Borg, and the variety acutum, Newman. These we may take as the two extremes, and the frond, fig. 1590 , is the intermediate state and type of the species; there are still many intermediate variations both as to size and form, but we are not able to find in any of them characters sufficiently constant by which to establish a specific difference. We have specimens now before us of fronds fully in fruit, which measure from the end of the stem to the apex of the frond three inches and a half long and one inch wide, and others twenty-four inches long and four inches and half wide; the former is a small specimen of the variety obtusum, the latter a large specimen of the variety acutum; but notwithstanding this great disparity, there are intermediate states to connect them, and also the want of specific character, besides that of form and magnitude to distinguish them.

Not any of our species of fern are more generally distributed than this. It does not seem to be exclusively attached to any particular soil, but grows equally well on the one as the other. it is found flourishing in the crevices of rocks, old walls, and ruined buildings, and under hedge rows, and it is in many situations extremely pretty and ornamental, especially upon old decayed ruins and the banks of rural dells. 
Whatever medical properties it possesses they have of late year's been entirely neglected; but Ray says it was believed to be useful in coughs, asthma, and other affections of the chest, and valuable for the relief of pain in the kidneys and bladder, arising from calculous obstructions; it was recommended by Hoffman in scorbutic affections.

3. A. lanceo'latum. Hudson. (Fig. 1591.) Green lanceolate Spleenwort. Fronds lanceolate, bi-pinnate or pinnate; pinnæ opposite, and arising at right angles from the rachis, lanceolate, or ovate, pinnate, or cut, and the lobes serrated; rachis not winged; lateral veins branched, and terminating in a linear club-sbape before reaching the margin, which is distinctly impressed on the upper surface; sori near the margin ; indusium linear, ovate, with a waved or notched margin.

English Botany, t. 240.-English Flora, vol. iv. p. 298.-Hooker, British Flora, ed. 4. vol. i. p. 388.-Newman's British Ferns, p. 249.

Roots slender, very long, branched, black, tough. Rhizoma tufted, dark brown, densely clothed with slender scales. Fronds curled up in vernation, when expanded erect, becoming drooping, and often pendulous, measuring from four to eighteen inches long, the naked part of the stem being nearly one half its length, though often only a third. The stem is mostly a dark reddish brown, some. times green, deeply channeled above, and clothed with narrow scales, especially at the base. The pinna always arise at nearly right angles from the rachis, and are almost always opposite; the first pair are generally shorter than the second. They are of a lanceolate figure, with opposite pinnules, the first pair of which are usually larger than the others, and the upper one the largest of the two; they are of an ovate lanceolate figure, aeeply cut in a pinnatifid manner and serrated, or simply serrated; each one is on a short footstalk, but towards the point they are decurrent. The upper surface is a bright cheerfuI green, the lower pale and dull; the mid-rib is prominent, slightly waved, the lateral veins and their branches terminate in an elongated club.shaped manner below the point of each tooth, which is distinctly impressed on the external surface, as seen on the pinnule (fig. $a$, page 61 ), and on the under surface from the inner margin of these bulbs the sori arise consequently near the points of each tooth (figs. $b$ and $c$, page 61.) They are at first linear, ovate, sometimes becoming circular, and as they advance to maturity confluent, entirely covering the frond with dense thick masses. The indusium (fig. $c$, page 61) is of a linear half ovate figure, entire or waved, or notched on the margin, and of a pale thin delicate texture. The thece are globose, encircled 
with a beaded elastic band, and attached to the frond by an elongated pedicel. The sporules are ovate, angular, and roughish.

\section{Habitat. - Fis.} sures of rocks and walls in the vicinity of the sea; rare. It is found on the coast of Cornwall, Devonshire, Kent, Sussex, Gloucestershire,
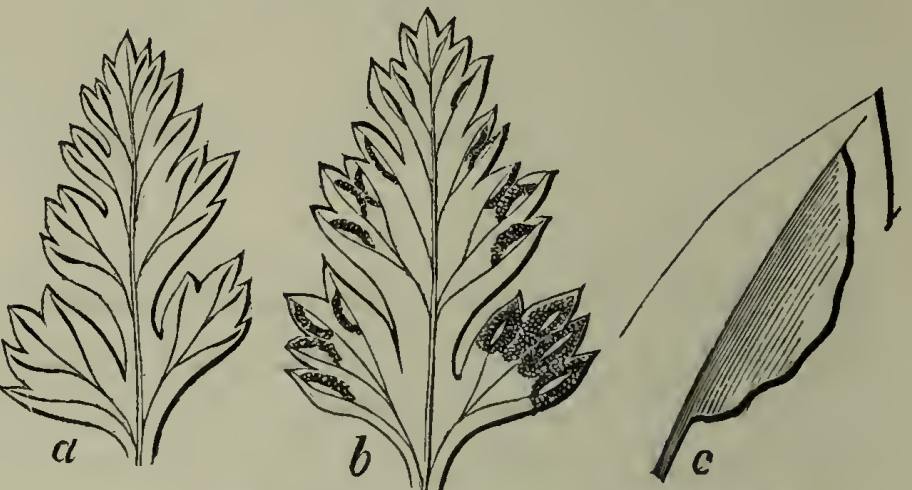

Caernarvonshire, Merionethshire, and Pembrokeshire, but nowhere very abundant.

Perennial; in perfection in August.

The illustration which we have given of this very beauti ul species of fern is drawn of the natural size of an ordinary grown plant. They are occasionally found much larger, as well as much smaller, and, perhaps, in some of these extremes it may be difficult to define the species to which they belong; but as in the illustration so also in the description, we have endeavoured to avoid any of these extremes, and in all of the forms which have come under our notice, the dis. tinctive characters of the species are very obvious. The pinnæ are always at a right angle with the stem, as compared with $A$. adiantum. nigrum. The sori are always marginal, and the lateral veins are always impressed in their club-shaped extremity on the external surface, which is not the case with $A$. adiantum-nigrum. We do not insist upon of the club shaped terminus of the veins seen on the surface of the frond as a specific chracter, but only as one of the distinguishing characteristics, marking the difference between the two nearly allied species. We shall find this character in others of our species, as will be seen in $A$. viride, \&c.

$\mathrm{Mr}$. Newman has well pointed out three varieties of form in fronds, which he has observed: the first, he says, " is of erect growth, nearly linear, and simply pinnate, the pinnæ being stalked and lobed; in this state seed is abundantly produced, and the masses, when full grown, are perfectly circular." "A second variety," he says, "is of pendant growth, and larger size; is lanceolate in form; the pinnæ are pinnate, the pinnules stalked, serrated, and somewhat quadrate. The fronds often measure a foot in length, and sometimes fifteen and even eighteen inches; they usually issue from dark holes or crevices, or 


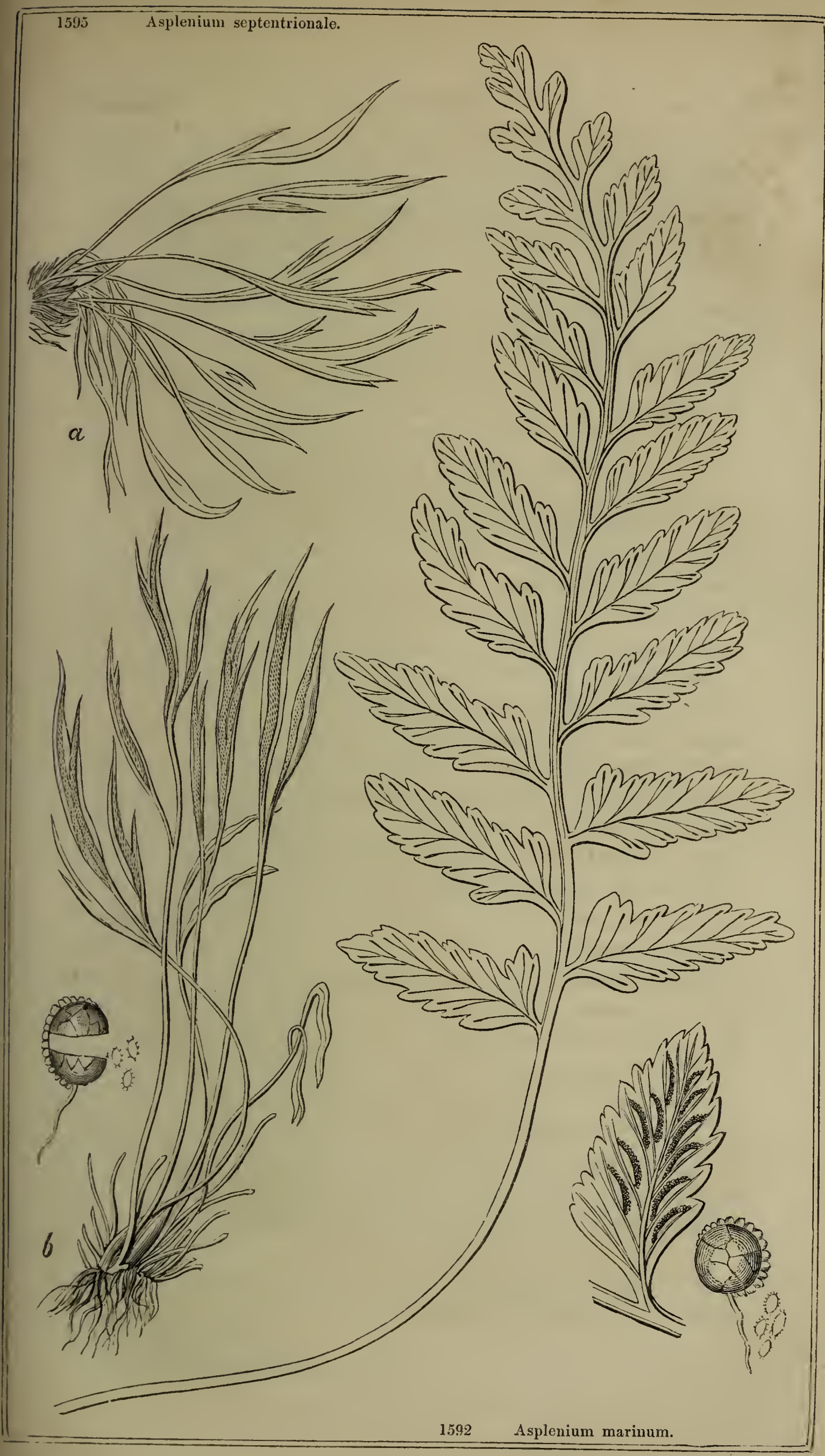



depend from the roofs of sea caves." The third variety which he mentions "is of nearly erect growth, but bends over at the extremity, and the entire frond, together with each individual pinnule, possesses such a rigid and inflexible convexity, that it is next to impossible to flatten it by pressure."

4. A. mari'num, Linn. (Fig 1592) Sea Spleenwort. Frond linear, simple, pinnate ; pinnæ oblong, obtuse, alternate, stalked, lobed and crenated, or simply crenated; rachis with a narrow wing on each side connecting the pinnæ; lateral veins simple or forked, and terminating before reaching the margin; sori about the middle of the lateral veins; indusium linear, with an entire margin.

English Botany, t. 392.-English Flora, vol. iv. p. 294.-Hooker, British Flora, ed. 4. vol. i. p 388.-Newman's British Ferns, p. 275.

Roots long, slender, tough, and wiry, black. Rhizoma tufted, black, and scaly. Fronds linear, or linear lanceolate, and simply pinnate, and varying from two to twenty inches long, The stem is a dark purplish brown colour, almost black at the base, slightly channeled above, rounded at the back, the lower naked part varies from a sixth to one half of the whole frond, but usually it is about a fourth; it is smooth and naked, except occasionally with a few scales at the base. Pinne simple, alternate, rarely opposite. oblong, ovate, obliquely tapering at the base, and one connected with the other by a narrow membrane running along the rachis. The margin is simply or doubly crenated, sometimes lobed, especially the lower ones, which are often lobed in an auriculated manner, especially on the upper margin: each pinna has a distinct prominent mid-rib and lateral veins, which are simple or branched, each terminating in a sligbtly thickened point before it reaches the margin, and bears on its inner margin linear sori, which always open towards the mid-rib, and as they advance to maturity become conflexed, and often entirely cover the frond by their thick masses of thecæ. The indusium is linear, a pale thin brown membrane, often nearly the whole length of the vein, but usually not more than half, and arising about the middle of the vein. See the drawing of the detached pinnule representing the under side (fig. c, page 70.) Thecce numerous, globose, encircled with an elastic headed ring, and containing numerous ovate angular roughish sporules.

Hibitat.-Clefts of rocks and caves, and occasionully, though very rarely, on old ruins near the sea, especially in Scotland and Ireland, and in the Isle of Man.

Perennial; in perfection in Auguist. 
Our illustration of this plant is from an ordinary frond, and drawn of the natural size and proportion; they are frequently, however, more linear in form than the one there represented and sometimes with the upper pinnæ even larger than the lower, and the point short and pyramidal. The auricuiated lobes at the base of the pinnæ are also sometimes much larger. In the accompanying representation of a frond drawn the natural size (fig. a), the pinnæ are narrower, and more deeply divided than any other that we have seen; it is thickly crowded with the confluent sori at the back, and is in. teresting as com-

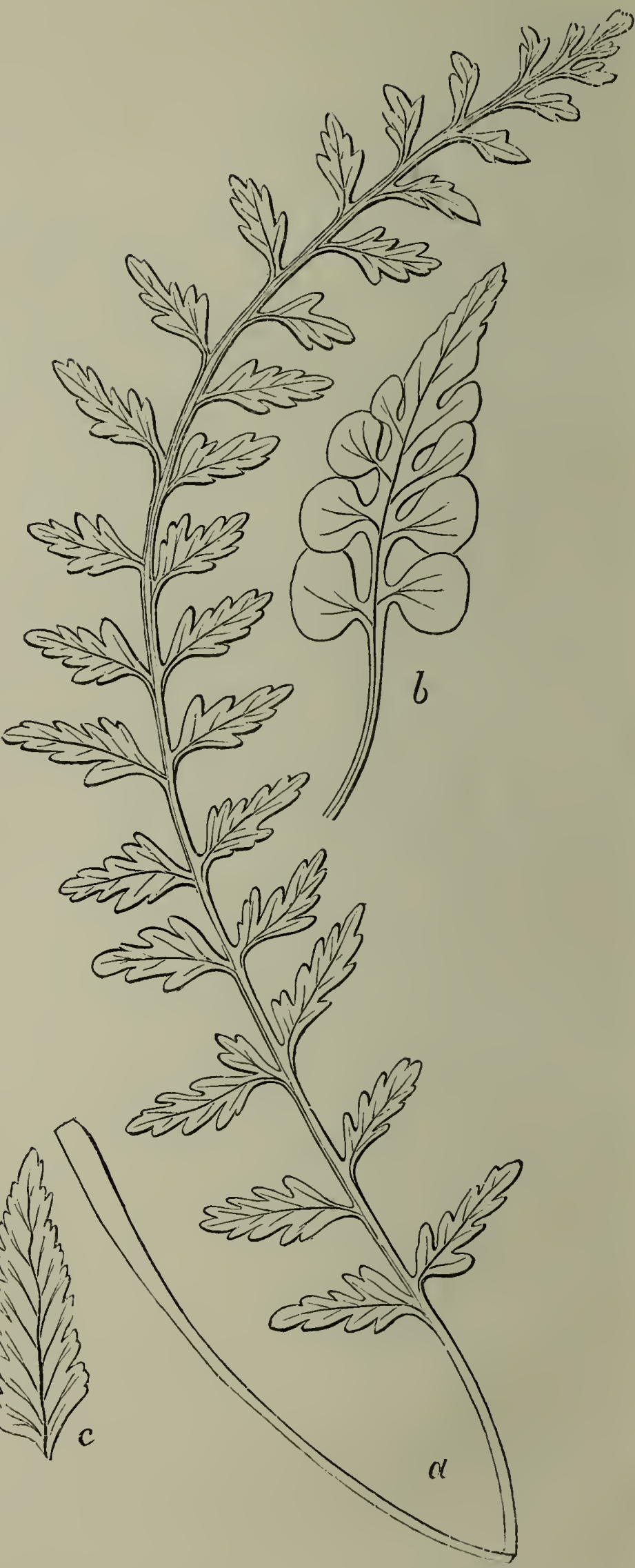
pared with fig. $b$, which is also a frond drawn the full size and 
proportion, and fig. $c$, page 70 , is a pinna from a frond, of a long linear figure, and all its pinnæ narrow, lanceolate, notched and crenated. These will be some guide to the students to the raried forms of the plant with which he may meet, but they all seem to depend upon the situation of their growth, being more or less confined to caves or close crevices of rocks, or as those more fully exposed to the influence of the saline atmosphere of the sea. This, indeed, seems to be one of the most necessary conditions to its full growth and perfection. It has been found, however, on rocks bordering the Lakes of Killarney, Ireland, by Mr. Newman, and near Warrington, and the village of Newton, on the Liverpool and Man. chester Railway, Lancashire; but there the specimens are all small, and stunted in their growth, much resembling our fig. $b$ both in form and size. Those stations for the plant are the most remote from the sea that we are aware of.

The young fronds rise from the black bristly scaled rhizoma in June and July, but are not in full seed until October and Norember, when they are mostly a dark green colour above, paler beneath, and remain so all the year. The veins of the pinnæeach terminate before reaching the margin, and are thickened or club-shaped at the end. They are simple or branched, as is seen in the detached pinna; each bears on its anterior margin both of the vein and its branch the sori. The thecæ are very numerous, of a bright brown colour.

As a medicine this Fern does not seem ever to have been much used. Ray recommen ?s it in cases of obstructions, and says that the mucilage, when extracted from it, and applied externally, is recommended for burns when all other applications have failed.

5. A. vir'ide, Huds. (Fig. 1593.) Green Spleenwort. Frond narrow, linear, elongated, simply pinnate; pinnæ quadrangular, ovate, cre. nated, altemate on short footstalks; rachis simple, green, not winged ; lateral veins simple or branched, and terminating before reaching the margin; sori near the base of the lateral veins; indusium ovate, with a crenated margin.

English Botany, t. 2257.-English Flora, vol. iv. p. 293.-Hooker, British Flora, ed. 4. vol. i. p. 388.-Newman's British Ferns, p. 281.

Roots long, slender, black. Rhizoma tufted, scaly, a purplish black. Fronds long, linear, simply pinnate, closely curled inwards in vernation, and covered with bristly scales, which, however, soon fall off, expanding into a linear elongate frond, from two to eight inches long. The stem is quite smooth, channeled on the upper side, 
rounded at the back; it is naked about one-third of its length at the lower part, and of a bright purplish brown colour, black at the base, the rest is a pale green, like the pinnæ. Pinnce mostly alternate, distant in the lower part, close above, some. times crowded, each on a short footstalk, and quite distinct one from the other, of a bright cheerful green, and thin texture, of a quadrangular ovate figure, tapering at the base often obliquely, the margin of the two upper sides crenated, rarely lobed. They are variable in figure, as will be seen from the marginal illustrations. Their lateral veins are simple or branched, and terminate before reaching the margin in a thickened or club-shaped manner (fig. a.) The sori are half linear ovate, or ovate, beeoming confluent circular
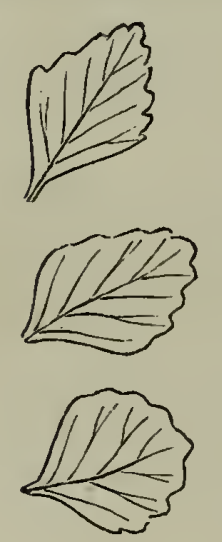
masses; they arise from the inner margin of the lower half of the lateral veins (fig. $b$ ), and mostly below the origin of the branches, when they are present, which is far from being constantly the case. The indusium (fig. c) is half linear ovate, pale, thin, membranous, waved or notched on the margin, which disappears as the masses of thecæ spread and become confluent. The thece are a bright chestnut brown, globose, with an elastic beaded band encircling them, which in time ruptures the delicate membranous sides, and allows the angular rough sporules to escape.

Habitat.-Mountainous districts of England, Scotland, and Ireland, especially in the vicinity of waterfalls; but not very common.

Perennial; in perfection in August.

This very beautfful and elegant little Fern is well characterised by its specific name, viride, for its fronds are amongst the most beautifully cheerful green of any of our species, and its rachis is always of the same colour, the lower part of its stem only being of a brown colour. The drawing illustrating this species is made the natural size of the plant. The pinnæ (fig. $a, b$, ) are magnified, to show more clearly their structure; and fig. $c$ still more so, to show the form of the indusium; while the above sketches of some of the different forms of the leaves will give an idea of their variableness. It is, however, one of the least variable of our species, and one which the student will have the least difficulty in referring to its proper place. The following species is its nearest ally, but there are characters, as will be seen, so distinctive, as readily to divide them one from the other. 


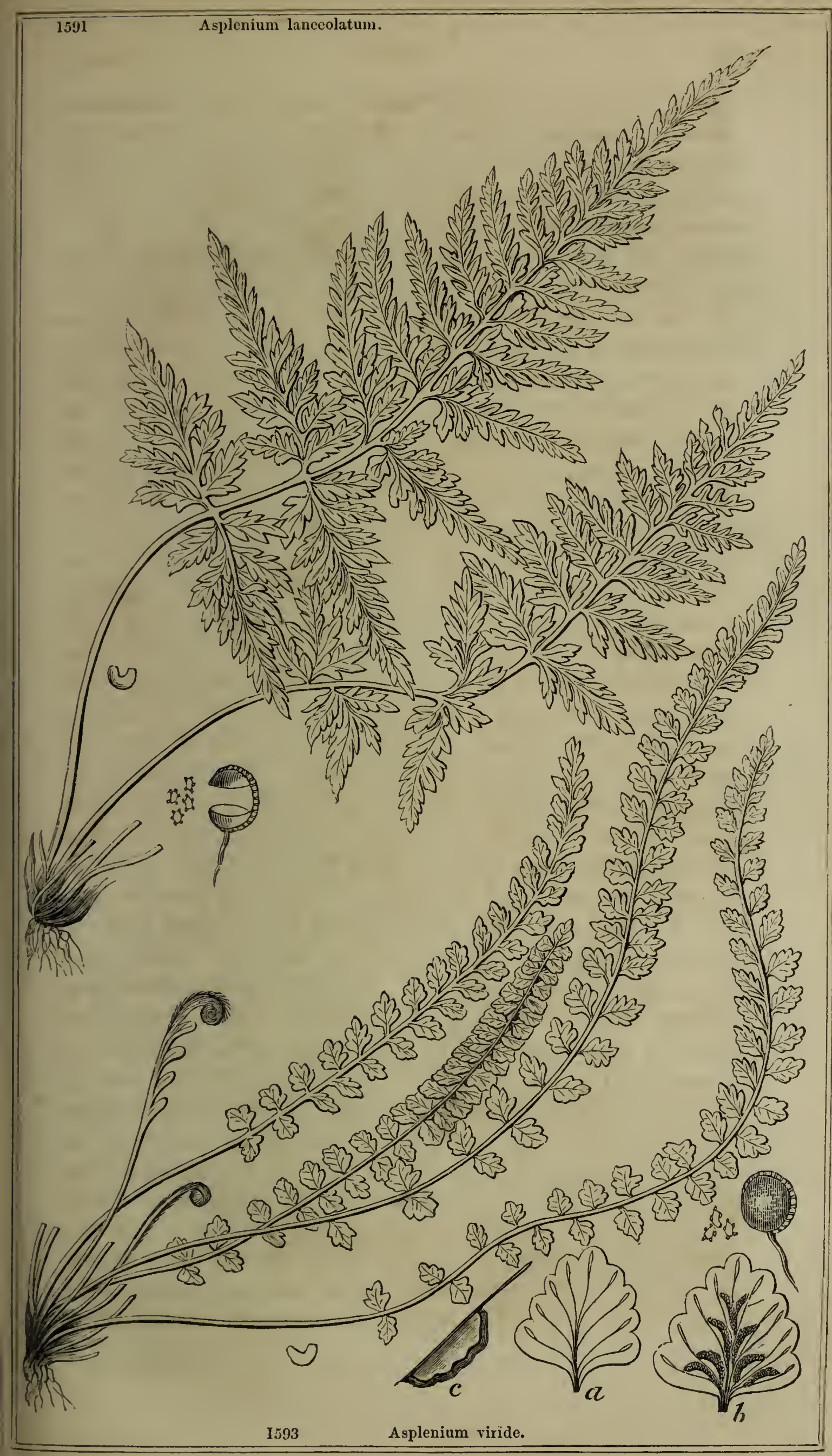


45
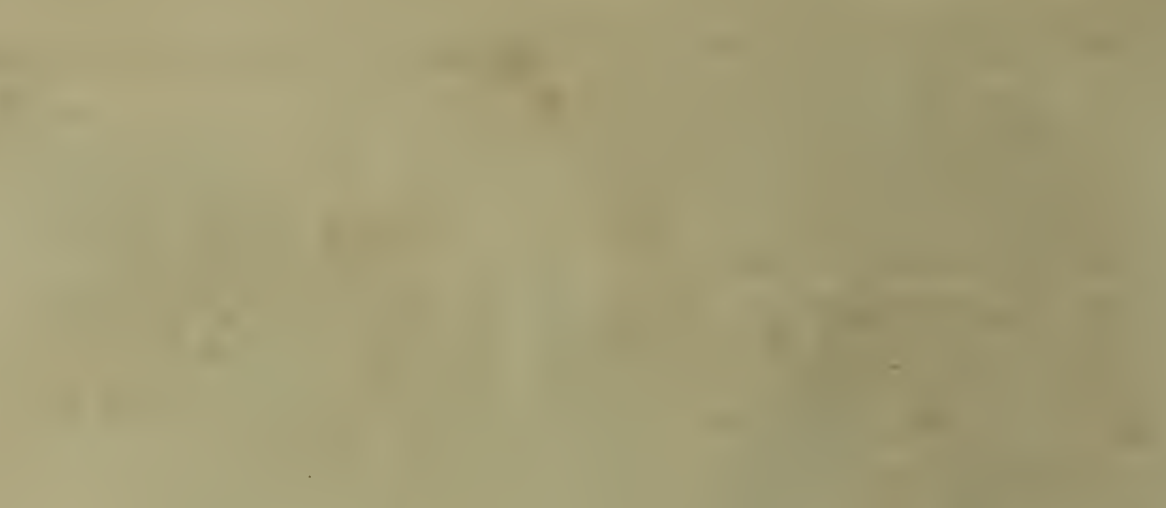

$\sqrt{2}$

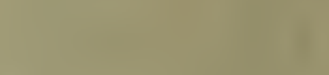

na

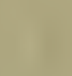
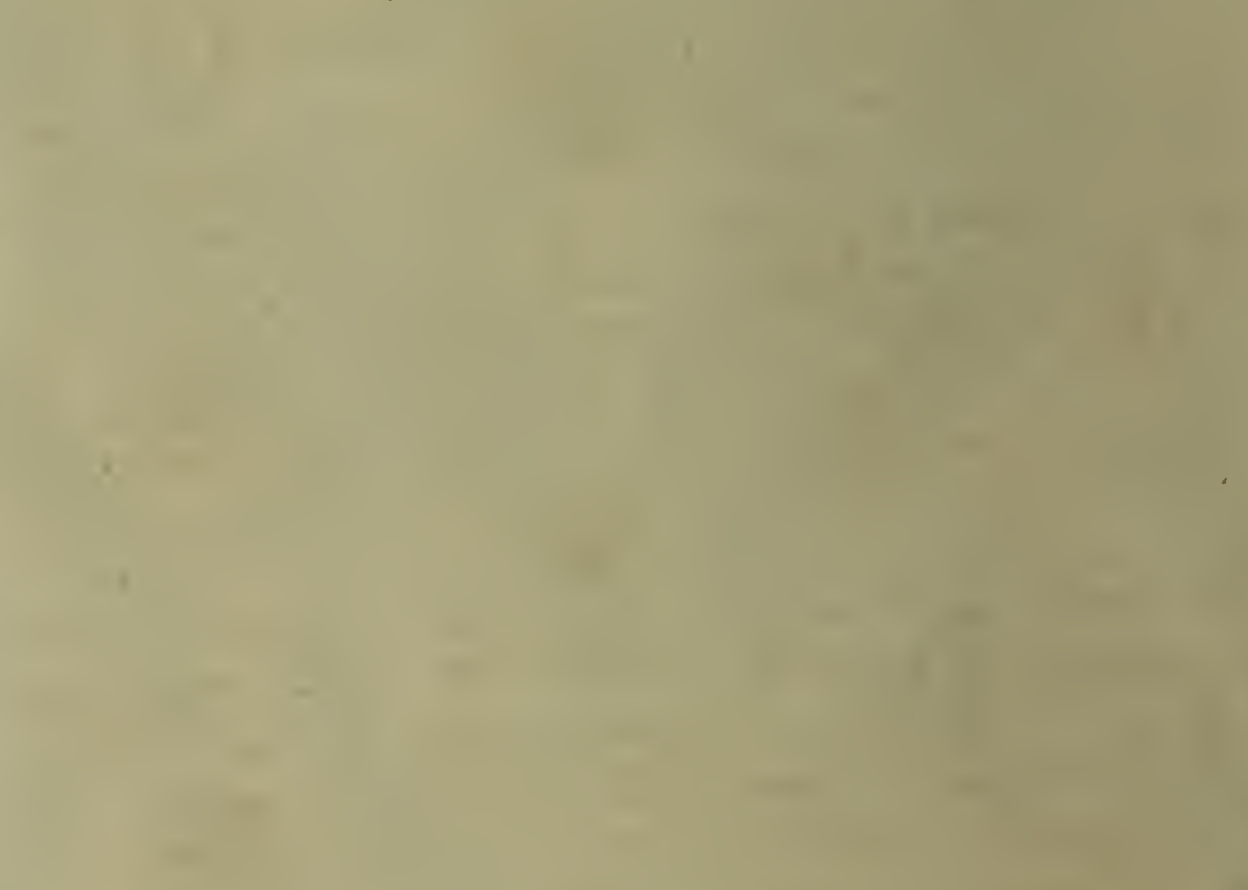

(n)
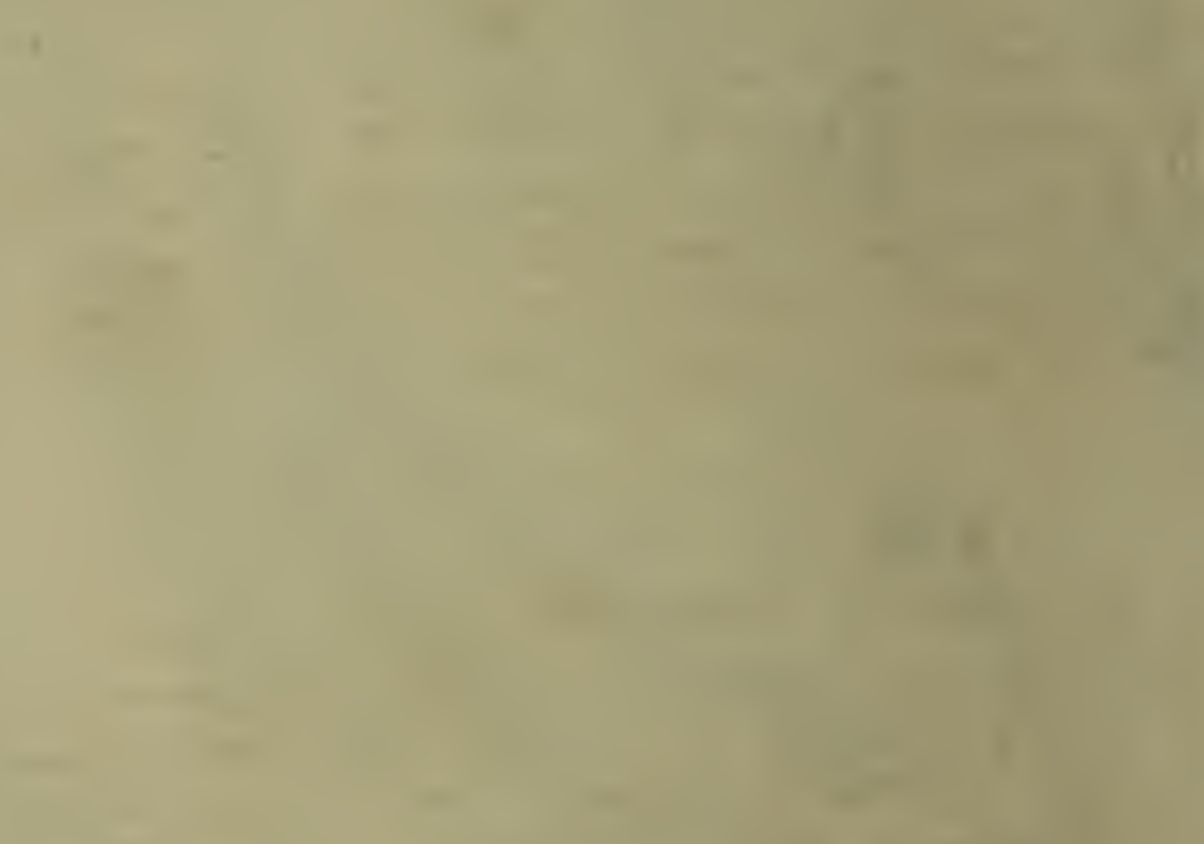

10

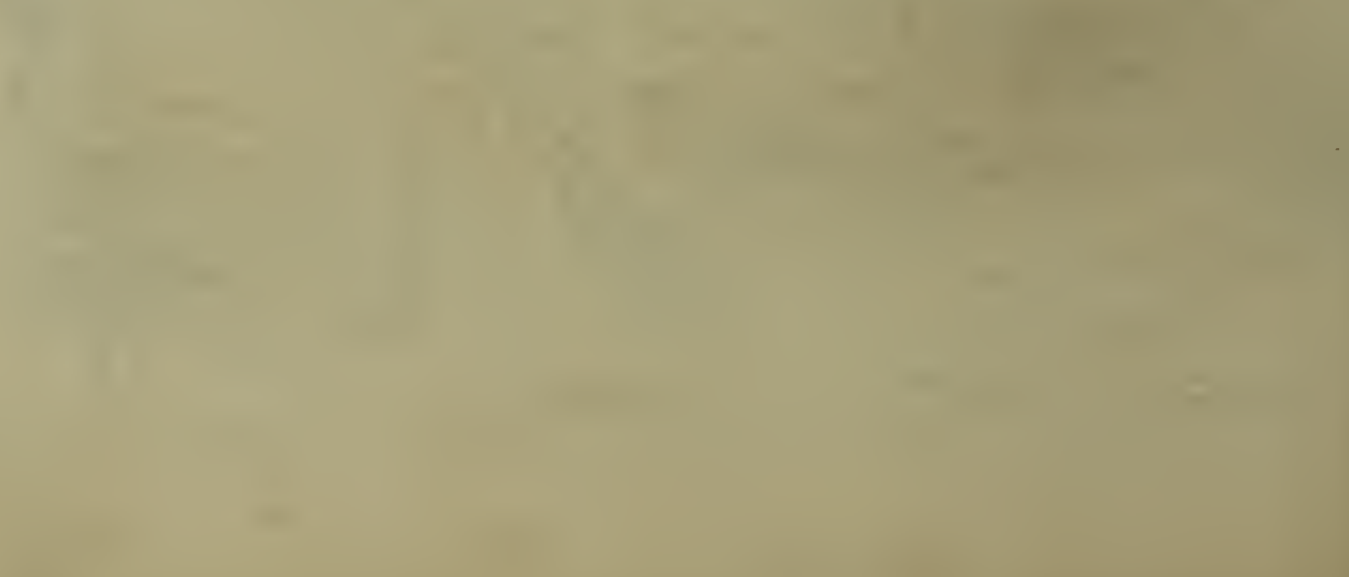


6. A. Tricho'manes, Linn. (Fig. 1594.) Common Wall Spleenwort. Frond narrow, linear, elongated, simply pinnate; pinnæ roundish oblong, obtuse, unequally crenated, on a short footstalk; rachis simple, black, not winged; lateral veins branched from near the base, und terminating before reaching the margin; the anterior branch bearing the sori about its middle; indusium linear, with an even margin.

English Botany, t. 576.-English Flora, vol. iv. p. 292.-Hooker, British Flora, ed. 4. vol. i. p. 387.-Newman's British Ferns, p. 285.

Root long, slender, black, fibrous, and wiry. Rhizomà tufted, black, and scaly. Frond curled up in vernation, gradually expanding into a linear elongated form, gracefully drooping and varying from three to twelve or fourteen inches long, simply pinnate, the pinnæ opposite and alternate. S'tem quite smooth, shining, purplish brown its entire length, almost black at the base, very brittle, with a broad narrow channel on its upper side, having a narrow membranous wing of a paler colour, rounded at the back, a transverse section of which is represented in fig. $a$. The lower part is naked, varying from a third to a sixth of its length; in the rest the pinna are alternate or opposite on short footstalks, generally of a roundish oblong obtuse form, somewhat wedge-shaped at the base, and more or less deeply and equally crenated on the margin. Thus, the general form is variable, some of the more remarkable ones are represented in the marginal figures; the lower one is almost pinnated, it is so deeply cut. They are usually quite distinct, as seen in the plate in the two varieties there represented, but occasionally they are so crowded as to overlay each other. The lateral veins are mostly branched from near the base in a forked manner, the anterior branch bearing the sori about its middle. They terminate just before reaching the margin, and are very slightly enlarged; in many, bowever, they are not so. The indusium is linear, of a pale thin memblanous texture, having its margin entire, or slightly crenatea, as seen in the detached pinna, which is drawn larger than generally found The sori, us they expand, become confluent, and cover the whole back of the pinnæ in one mass of theca, which are small, globose, with a beautiful elastic ring encircling them. Sporules minute, angular, roughish.

Habitat.-Rocks, walls, old ruins, banks, and hedge rows; frequent. Perennial ; in perfection in August.

This is one of our most generally distributed and common Ferns, 
forming frequently in favourite situations for its growth on old damp walls or bridges a most beautiful and elegant covering, a living tapestry, which no art can imitate, and every description must fail to convey any idea of such of nature's works in her luxuriance. Our drawing represents a moderate sized specimen the natural size. The detached pinna is not larger than is often found growing in moist shady places, and shows the under side. The marginal figures of some of the varied forms are also drawn the natural size. The lower one is extremely rare, for this species is perhaps the most constant in its characters of all our Ferns; which is remarkable, considering the very varied situations in which it grows, and how widely it is distributed. It is remarkable also in the munner in which the pinna falls from the stem after it has accomplished its purpose, in the same way that the leaves fall off from the stem and branches of flowering plants.

As a medicinal plant this was much celebrated in former days for the cure of coughs, colds, and various affections of the chest, and was administered in the form of tea, or made into a syrup ; but it has now-a-

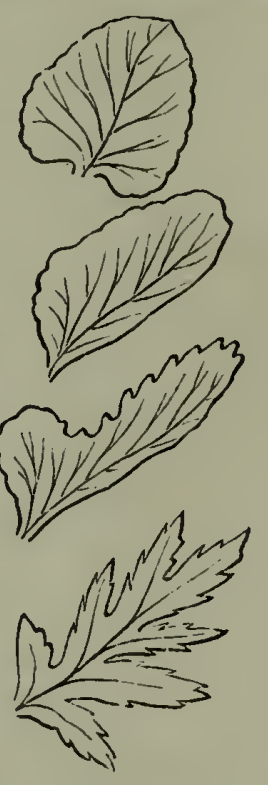
days lost its reputation, and is rarely, if ever, used for such like affections.

7. A. septentriona le, Hoff. (Fig. 1595.) Forked Spleenwort. Frond elongate, lanceolate, lobed and bifid at the apex, the teeth acute; stem green, except quite at the base; veins simple, one running into each tooth; sori linear on the inner margin of the veins; indusium linear, entire on the margin.

English Botany, t. 1017. -English Flora, vol. iv. p. 295.-Hooker, British Flora, ed. 4. vol. i. p. 387.-Newman's British Ferns, p 269.-Acrostichum, Linn.

Roots long slender branched fibres, much entangled. Rhizoma tufted, often very large, forming an entangled mass, and putting out numerous fronds, which grow erect, horizontal, or drooping, according to the position in which the plant has fixed itself upon the top or side of a rock or wall. They are from one to four inches long, slender, channeled on the upper side, rounder on the under of the stem, green, except quite at the base. The frond is of a lanceolate figure, narrow, tapering at the base, and terminating in a long slender curved point, or lobed, with one, two, or three lateral lobes, seldom 
more, which are bifid at the point, or simply pointed, veined or ribbed on the upper side, and a darkish green, paler on the under side. The lateral lobes are simply cut, as it were, from the main frond, as seen in the upper plant of our plate, (fig. a,) or the lateral lobes form $u$ distinct pinna, elevated on a footstalk, as seen in the lower plant (fig b.) The sori are linear, as long or nearly so as the pinna arising from the inner margin of the lateral veins. The inclusium is a long linear lanceolate pale thin membrane, with an entire margin, or slightly waved. Each sori has but one indusium; but when the opposite lateral veins each bear a sori, it appears as though it was a single sori, with a double indusium, which will be seen in the fronds of fig. $b$. As the thecæ become developed, the sori are confluent, and they in time form a thick mass, covering the whole pinna, and push away the indusium and destroy it. The thece are dark brown, globose, very numerous, and contain many ovate angular roughish sporules.

Habitat - Fissures of rocks and interstices of stone walls; rare. Carnarvonshire, in Wales. Northumberland, Westmoreland, Cumbcrland, Somersetshire, and according to Tofield, on Ingleborough, Yorkshire, England. Near Edinburgh, and at Stenton Rock, near Dunkeld, Perthshire, Scotland.

This very rare and remarkably formed plant is so dissimilar to any other of our species, that there is but little fear of its being mistaken for or confounded with them. The two specimens which we have given in illustration are both represented as they were found growing, and are from Arthur's Seat, near Edinburgh. The upper one, $a$, is as it grew from the fissure of a rock; $b$ from the ledye of a rock, nearly erect, where it was supplied with a greater quantity of moisture.

The fronds first make their appearance in March and April, but do not attain their perfect state before August, and they remain green the whole year. Though a rare plant, it has an extensive range of growth; it will flourish near the sea amidst its saline atmosphere, and we have found it high on the Alpine mountains of Switzerland, as well as on the elevated mountains in the Appennines of Italy.

\section{A. Ru'ta-muraria, Linn. (Fig. 1596.) Wall Rue Spleenwort} Frond triangular, bi- or tri-pinnate; pinnules obovate, wedge-shaped, or linear wedge-shaped, toothed or crenated; indusium crenated or jagged on the margin.

English Botany, t. 150.-English Flora, vol. iv. p. 296.-Hooker, British Flora, ed. 4. vol. i. p. 388.-Newman's British Ferns, p. 261. 
Roots loug, branched, black, tough and wiry, more or less downy. Rhizoma thick tufted and scaly, black. Fronds green, from one to six inches long, or eren more. The stem is slender, channeled on its upper side, crowded at the back, green in the upper part, dark brown or black at the base, where too it is swollen. The form of the frond is triangular, oblong, and bi- or tri-pinnate. The pinnce are stalked, and the pirnules also are mostly on a short footstalk; they are of a lozenge-shape, or roundish, with a wedge-shaped base, or linear ovate, or narrow wedge shaped. The upper margin is crenated, or obtusely serrated, sometimes lobed. The veins all urise from the base, and are divided upwards, each branch terminating in a tooth Sori mostly numerous, linear, attached to the inner margin of the veins, shortly becoming confluent, and covering the back of the pinnule in one mass of thecæ. The indusium is pale, thin, membranous, linear, with the margin jagged or sinuated (fig. $a_{\text {:) }}$ but this soon becomes pushed aside, and disappears by the increase of the thece, which are numerous, globose, brown, and encircled with an elastic beaded ring.

Habitat.-Old walls and the fissures of rocks; abundant.

Perennial; in perfection in September.

This little Fern will be familiar to all who have been in the habit of looking around them in search of botanical specimens, for it locates itself in the mortar of almost every old wall or ruin in most parts of England, Scotland, and Ireland. These situations it seems to prefer to the rocks and wilds of

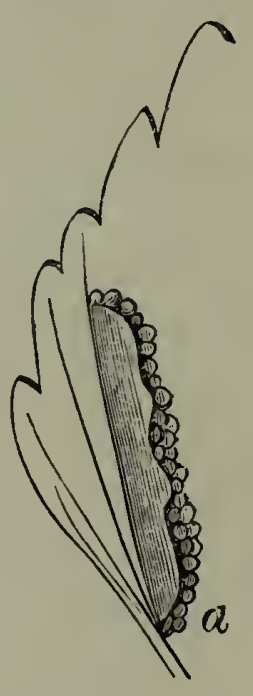
nature, producing its elegant tufts of fronds of greater or less length and size, according to its more or less favourable situation of growth. Our plate illustrative of this species is drawn from a fine well-grown plant of the ordinary kind, but not of either an uncommon size or developement, and may be considered the normal form of the species. Its variations, however, are so striking, as will be seen from our marginal illustrations, that it has induced in some botanists the belief that the following species is only one of its varieties; the constancy, however, of the simply pinnate fronds, and the entire even margin of the indusium, will keep the latter a separate species. The detached pinnule is drawn larger than the natural size, to show the distribution of the veins and the siluation of the linear sori; and the back of one of the fronds shows the thick mass these sori form as they advance to 


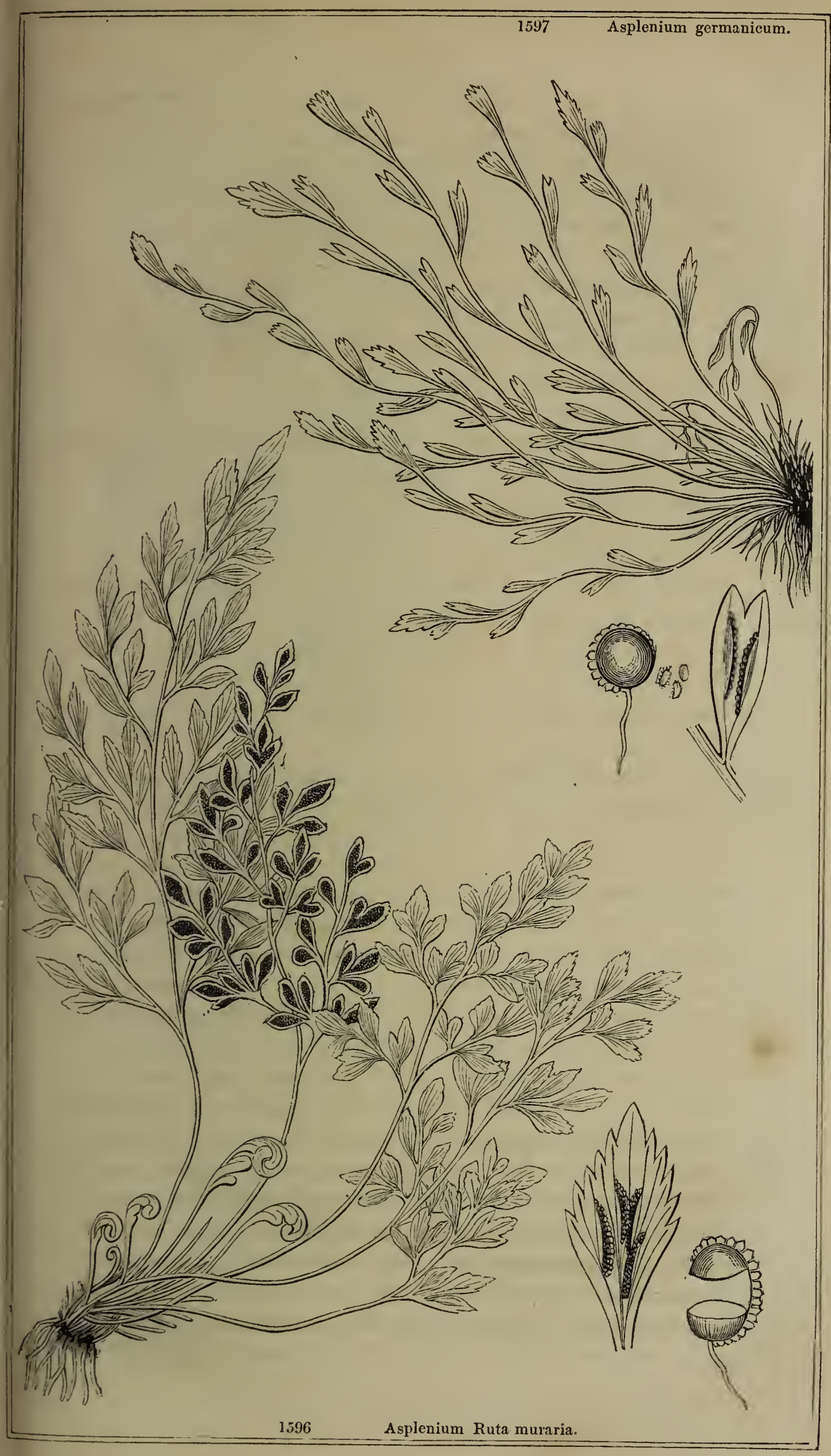



maturity and become confluent. The lower frond represented in the marginal illustration of the varieties is the most remarkable which we have found. It grew in a very thick tuft upon a wall close to another cluster of the same species, but with fronds resembling that

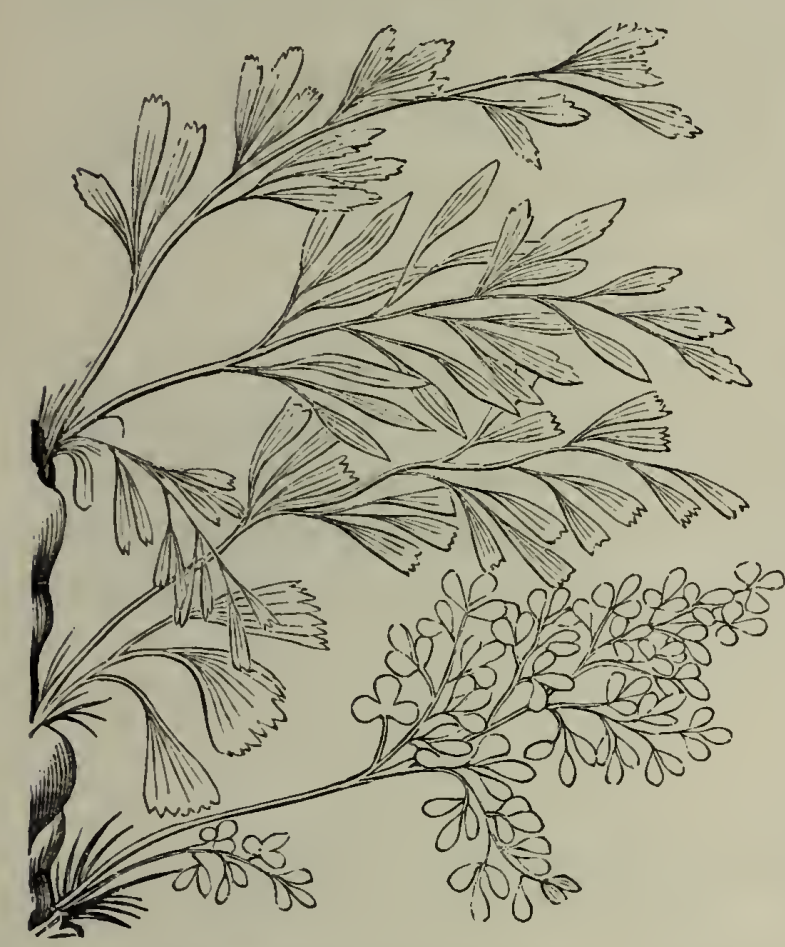

of fig. 1596. Its pinnules are almost circular, flat, and entirely covered at the back with the confluent sori. The frond is drawn the size of nature. The fronds represented in the sketch above this grew upon a rock in a shady damp situation.

The medical virtues of this plant are said by Lightfoot to be pectoral, and that it was formerly sold in the shops as a remedy for the relief of coughs, asthmas, obstructions of the liver, spleen, and in scorbutic complaints. It is not now used as a medicine, except by country dames in their domestic nostrums.

9. A. germani'cum, Weiss. (Fig. 1597.) Alternate-leaved Spleenwort. Frond linear, simply pinnate ; pinnæ alternate, rєmote, wedge-shaped, notched and toothed at the apex; indusium entire on the margin.

Newman's British Ferns, p. 265.-A. alternifolium, Wulf. English Botany, t. 22a1.-Hooker, British Flora, ed. 4. vol. i. p. 387.English Flora, vol. iv. p. 296.-A. Breynii, Retz.

Roots long, branched, black, tough and wiry. Rhizoma thick, black, scaly. Frond narrow, linear, green, simply pinnate. The stem is green, mostly waved, channeled on the upper side, rounded at the back, and black, or dark purplish black at the base. The pinne arise alternately almost erect, and remote from each other, are of a linear wedge-shaped form, on a short footstalk, are bifid or toothed at the end, sometimes on the side. The terminal pinna is mostly more pear-shaped and toothed. The veins all arise from the base, sending a branch to each tooth, and bearing on the inner margin, as seen in the detached pinna, linear sori, which become confluent as the plant 
advances to maturity. The indusium is a linear thin pale membranous structure, with an entire margin. 'The theca globose, with an elastic beaded ring encircling it, and the sporules are angular, ovate, roughish.

Habitat.-Fissure of rocks; very rare. Three miles from Dun fermline, Fifeshire.-D. A. Dewar. Hooker.-Stenton Rocks, near Dunkeld, Perthshire.-Mr. Williamson. Newman.-Rocks in South of Scotland.-Mr. Dickson. Some sunny rocks about two miles from Kelso on the Tweed.-Smith.

Perenuial; in perfection in September.

Wild British specimens of this very rare Fern we have not been able to procure, so that our illustration is made from continental ones. It is drawn of the natural size and proportions, as situated upon the place of its growth on a rock. The detached pinna is drawn larger than it actually grows, for the purpose of showing the situation of the sori and structure of the indusium.

GENUS XI. SCOLOPEN'DRIUM.-Sмiтh. Common Hart'stongue.

Gen. Char. Sori linear, transverse, on lateral veins, always double. Indusium appearing single from both, opening on the inner edge, and attached to the outer.- Name from the lines of fructification having some resemblance to the feet of a Scolopendra.

1. S. vulga're, Symons. (Fig. 1598 ) Common Hart's-tongue. Frond lanceolate, or oblong lanceolate, heart-shaped at the base; rachis scaly.

English Botany, t. 1150.-English Flora, vol. iv. p. 301.-Hooker, British Flora, ed. 4. vol. i. p. 389.-Newman's British Ferns, p. 289.S. officinarum, Swartz.-S. Phyllitis, Roth.-Asplenium Scolopen. drium, Linn.

B. polyschides, Ray. (Fig. a, page 79.) Frond linear elongate, the margin deeply and irregularly lobed and crenate.

$\gamma$. crispa, Koch. Frond lanceolate, waved and unequally lobed on the margin.

S. lobata. (Fig. b, page 79.) Frond dilated at the end, and cut into lanceolate lobes.

घ. dadalea, Koch. (Fig. c, page 79.) Frond greatly dilated at the end, and divided into numerous unequal curled lobes, deeply erosed on the margin; stem divided. 


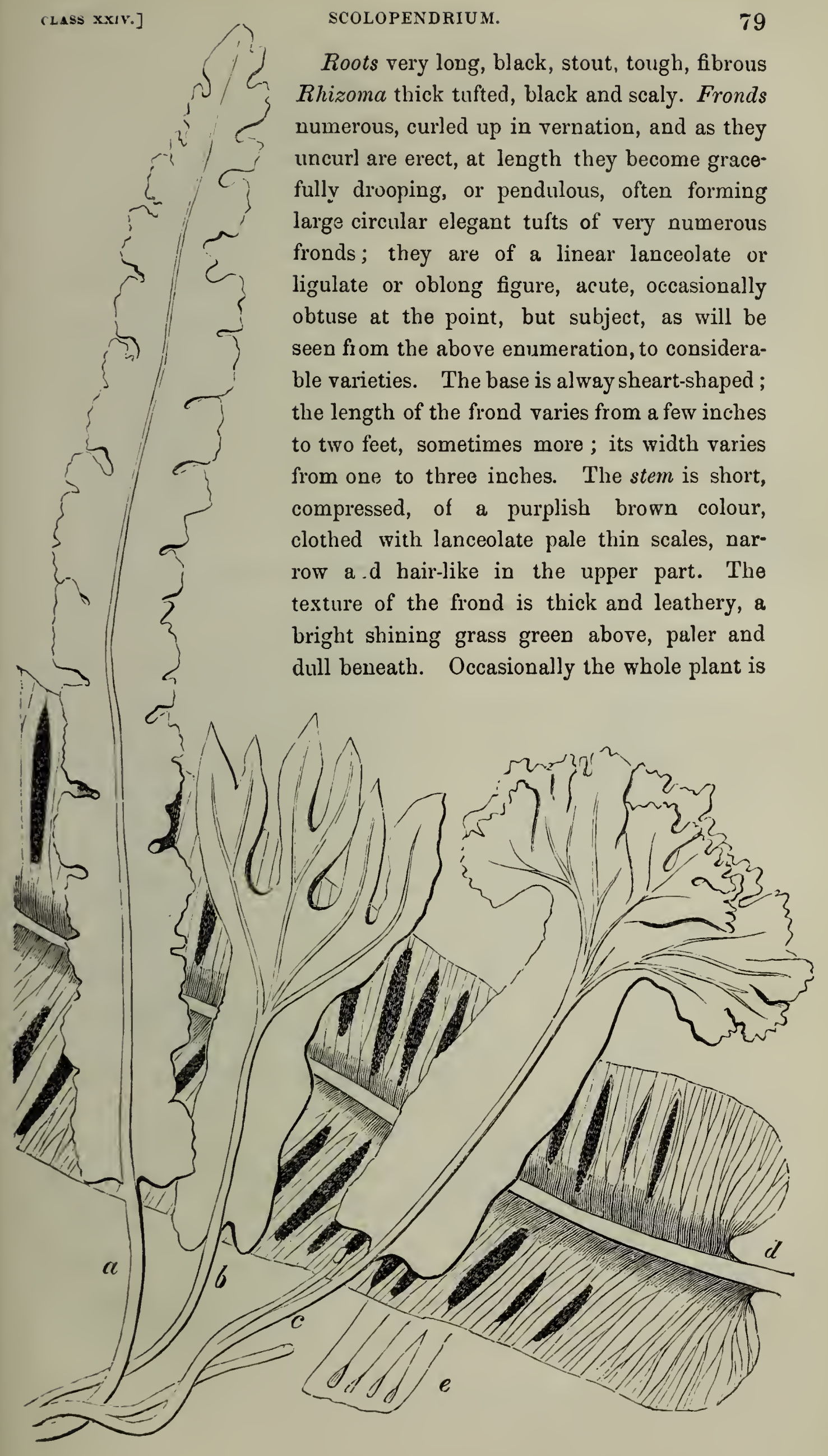


scattered over with hair-like scales, at other times it is only on this under side, and more frequently it is quite smooth. The stem, or rather the mid-rib of the frond, is stout, prominent on the under side, sends out numerous lateral veins, which are mostly bifurcated, or two or three branched (fig. $d$, page 79 ,) each branch terminating before reaching the margin in an oblong bulb, distinctly seen on the upper surface (fig. $e$, page 79.) The upper and lower branch of many of these sets of veins bears linear sori opposite each other, so that though there appears only one, they are in reality two united, and the thin membranous indusium bursting on the margins opposite each other, seeming to form a double valve to each sorus. As the masses expand, they push away the indusiums, which at length disappear, and the thecæ become so united as to form one mass. The sori are of very unequal lengths, and are more or less crowded. Thece numerous, crowded, brown, globose, encircled with a beaded elastic ring. Sporules roundish, rough.

Habitat -Shady banks, rocky and stony wet places, old walls and buildings ; common.

Perennial; in perfection in August and September.

This beautiful and remarkable Fern, commonly called Hart'stongue, is highly ornamental, delighting to grow on damp buildings or rocks in humid situations, forming large elegant tufts; and on the ruins of old bridges, aqueducts, or old walls, it often forms a most elegant covering, hanging its drooping form in great luxury.

\footnotetext{
"And there my friends

Behold the dark green frill of long lank weeds, That all at once (a most fantastic sight!) Still nod and drip beneath the dripping edge Of the blue clay stone."
}

Formerly this plant was admitted into the list of the Materia Medica, and was used as an astringent in cases of diarrhœa and hœmorrhages, and to form a kind of ointment for the cure of wounds, cuts, and ulcers; but it is now quite neglected, except by the country herbalists.

Our illustration of this plant is drawn about one-third the natural size, and shows the usual form and mode of its growth. The young fronds exhibit its convolute developement. Fig. 1 is a transverse section of the stem, showing the two pair of dark bands of ducts, which transverse its whole length, and ramify it into the lateral veins. The arrangement of the sori in this remarkable Fern we have endeavoured to describe, and fig. 2 is intended to show the 


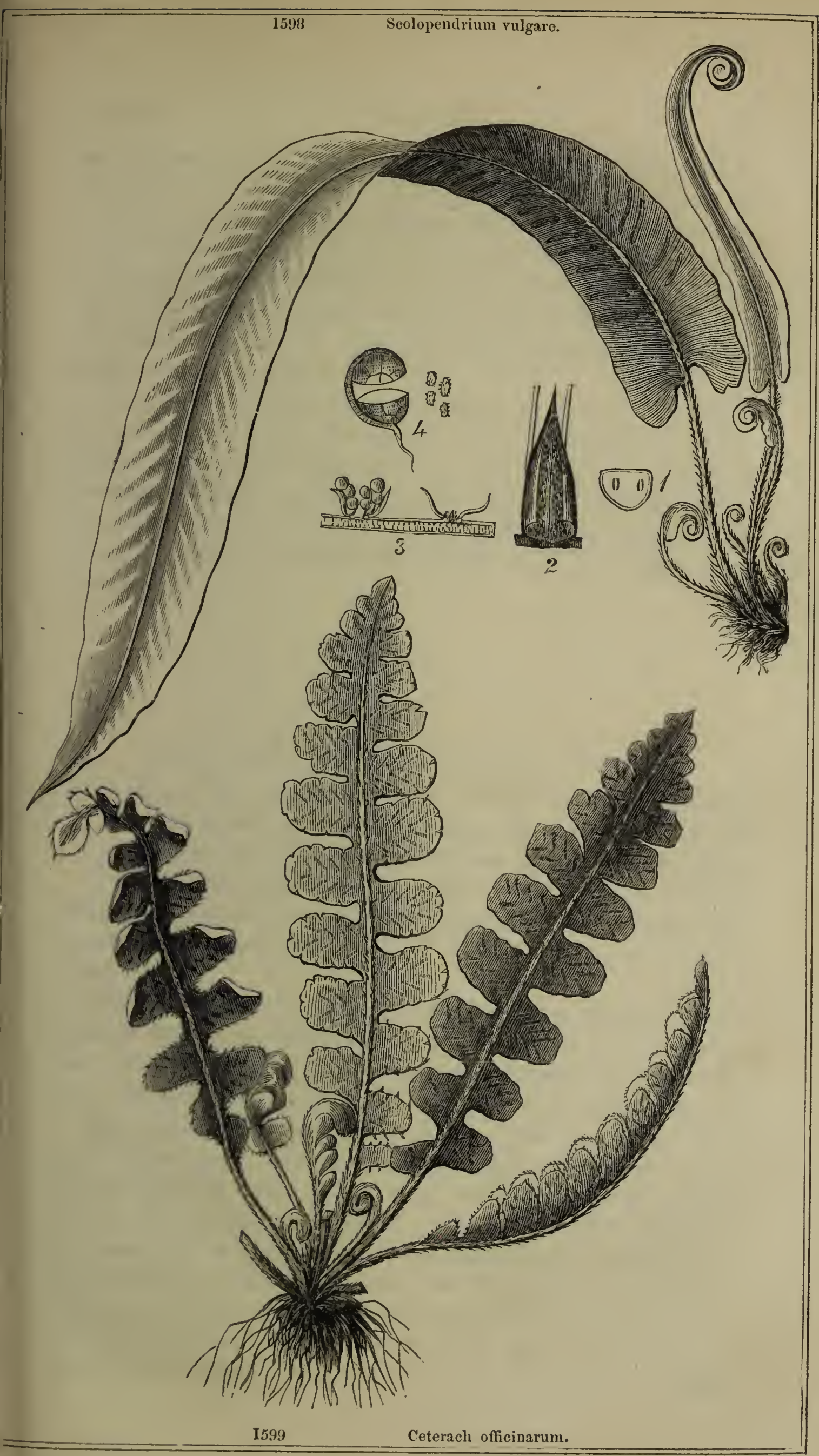


the upper end of one of the double sori, arising from the margin of the upper side of one vein and the lower of its opposite one; the indusium on each side being curled up on its free edge, and exhibiting the thecr beneath. Fig. 3 is a transverse section of a portion of the frond, and two of the sori; one shows the indusium, turned back by the rising thecæ on each side, the other shows the indusium, the thecæ being removed. Fig. 4 is one of the thecæ, and its rough sporules highly magnified.

The marginal illustrations are all drawn of the natural size. Fig. $a$ is the lower portion of a common sized frond, and exhibits the lateral veins and the sori in the natural state; some exhibit the sori with the indusium opening up on each side, the rest are the confluent masses, and fully developed. Fig. $e$ is a small portion of the margin of the frond, to show the club-shaped termination of the lateral veins magnified.

\section{GENUS XII. CETE'RACH.-WILLD. Ceterach.}

Gen. Char. Sori oblong, or linear, clusters scattered. Indusium obsolete, lateral veins anastomozing.-Name Chetherak, "which was applied by the Arabian and Persian physicians to this plant.

1. C. officinar'um, Willd. (Fig. 1599.) Scaly Ceterach, or scaly Spleenuort. Fronds pinnatifid, the underside imbricated with pale brown membranous scales; pinnæ oblong, obtuse, entire or waved, or lobed.

Newman's British Ferns, p. 293.-Scolnpendrum Ceterach, Sm.English Botany, t. 1244.-English Flora, vol. jv. p. 302.-Roth. Tent. 3. p. 48.-Grammites Ceterach, Swartz.-Hooker, British Flora, ed. 4. vol. i. p. 382.-Gymnogramma, Spreng.-Asplenium, Linn.

Roots branched, fibrous, black tufted. Rhizoma short, thick tufted, brown, scaly. Fronds numerous, spreading, from three to six inches high, of a linear oblong form, pinnatifid, of a thick leathery texture, dark green abore, smooth, or with a few scattered scales. on the rachis and margins of the pinnæ, thickly clothed beneath with ovate lanceolate scales, membranous, and beautifully reticulated like a piece of net work; those on the stem are narrower, more lanceolate, than those of the frond; at first they are white, but become in maturity dark brown. The frond is convolute in vernation; its stem 
is short and stout, as is the rachis. The pinna are oblong, obtuse alternate, entire on the margin, or waved or deeply notched, as seen in fig. a. The lateral veins arise obliquely from the lower part of the pinna, and branched from near their origin; the first branch is divided into two from near its base, and that division nearest the main stem bears its sorus, opening towards the main stem, while its other branch, as well as all the rest, open towards the main vein of the pinna, as seen in fig. $b$. The ultimate divisions of the veins often anastomose with each other, and terminate in the margin. The sori are linear, covered by the scales until they are fully expanded, and then become prominent, and burst through. The thece are numerous, dark brown, and arise, as above stated, from

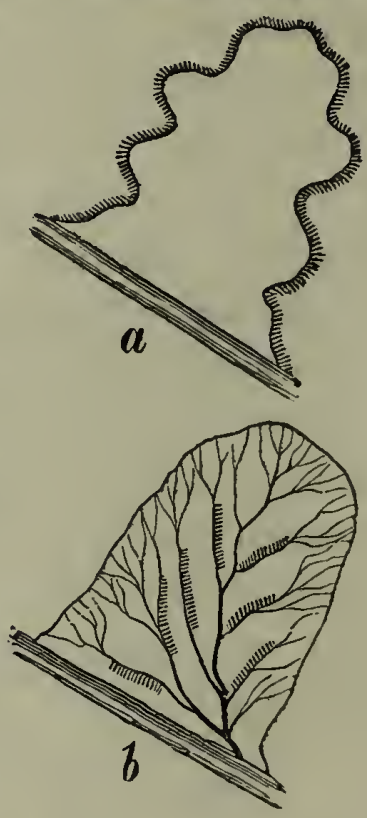
the margin of the lateral veins, which is thickened into a spo. rangia or receptacle, as seen in fig. $c$, which is a transverse section of the pinnæ through a sorus, and shows the lateral vein, and the insertion of the thecæ and the scales of the pinna. Fig. $d$ represents a sorus, and the manner in which the scales are arranged on each side, and which seem to arise on the upper side from or nearly upon the sporangia, and take the place of an indusium; for we have examined them in every stage, and have never been able to find anything more like an indusium than a slightly elevated line in the young fronds, and this disappears as they advance to maturity.

Habitat.-Rocks and old walls, especially

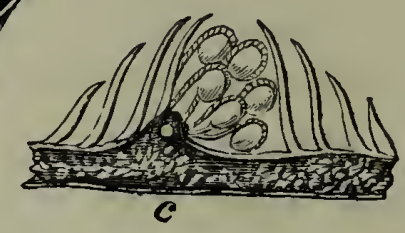
in limestone districts in the South-western

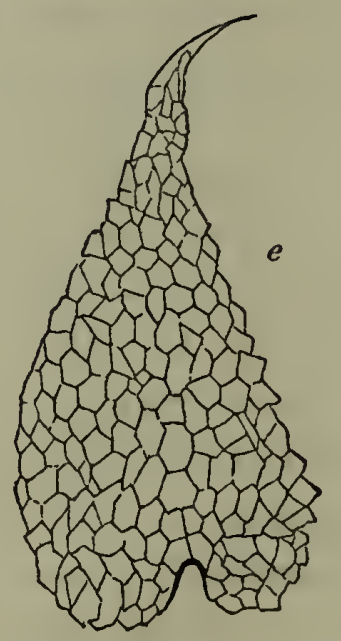
Counties of England and Ireland; less frequent in the Midland Counties, and rare in Scotland. Kilfinnan, Argyleshire; Kinnoul Hill, Perthshire ; near Paisley, Renfrewshire.

Perennial; in perfection in August. 
This plant was formerly used in medicine as a diuretic, and is still retained amongst the list of official plants in Italy. Dioscorides greatly extols its medicinal properties, and gives directions that a decoction of it in wine is to be taken for forty days successively; but that in some cases to perform a cure it is necessary that the plant should be gathered at night at the time when there is no moon. The decoction has a rough mucilaginous taste, and was thought to be useful as a pectoral medicine; but even for this purpose it is now quite neglected, as well as its application to wounds and ulcers.

The illustration of this species is made from an ordinary grown plant, and is drawn the full size. Often, however, in moist situations favourable for its developement, it grows to double this size, and the pinnæ are occasionally found deeply lobed, even much more than represented in the marginal figure $a$. The scales are a most beautiful object seen by the magnifying glass, having a finely netted appearance, as shown in figure $e$ in the preceding page, which is one from the back of the frond; those on the stem are more lanceolate, and often with a long tapering point.

The scaly Spleenwort is remarkable, from the dry and arid situation in which it grows, fixing itself on the face of rocks or the tops of walls, and sending its slender villous roots into the crevices or among the mortar, where but little moisture can be found; but it seems to require less moisture for its roots than many of the other species, provided it is in a humid atmosphere, for it appears to have the power of absorbing and retaining moisture more than many of the other Ferns, and this would seem to arise from the circumstance of its being so protected from the influence of the atmosphere and other causes, by which moisture is abstracted from the plant by its thick covering at the back, of overlapping scales.

It is a matter of dispute among Botanists as to whether this plant has or has not an indusium to the sori, some maintaining that it is present, and others that it is not. We have examined with great care many specimens at different periods of developement, but whether from the want of more delicate manipulation in the removal of the scales, or from some other cause, we have never been able to see more than a narrow projecting line which can at most be justly called an obsolete indusium, and this only because it is in the position where the indusium is usually found; and we may suppose from the abundant covering which the sori have in the scales that an indusium for the protection of the young thecæ is not necessary, and consequently is not formed. 
GENUS XIII. CYSTUP'TERIS.-BERN. Bladder-fern.

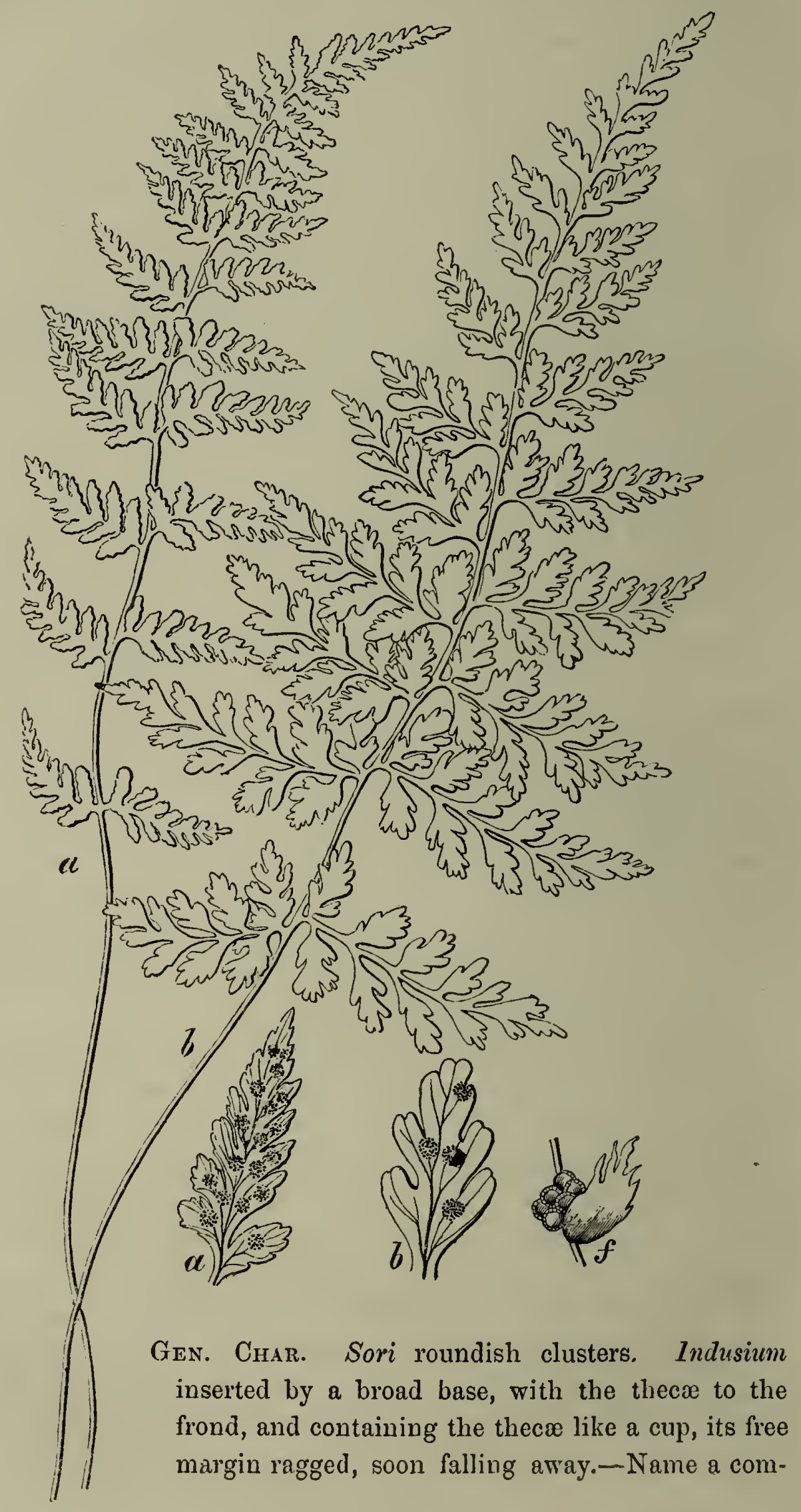




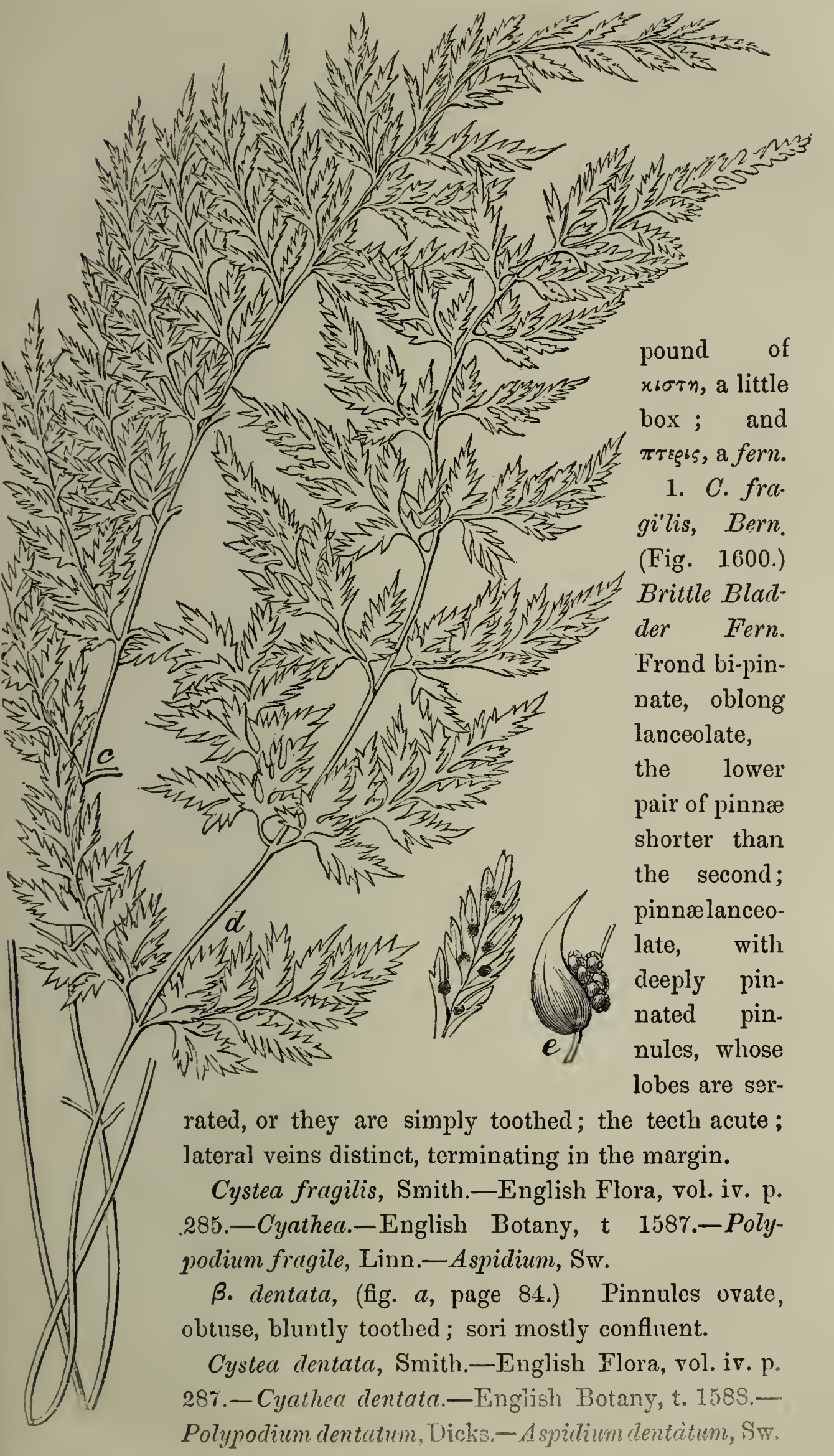


$\gamma$. cynapifolia, (fig. $b$, page 84.) Pinnules oblong, ovate, pinnate, its lobes oblong, notched at the apex.

Cyathea cynapifolia, Roth.-Polypodium cynapifolium, Hoffm.

S. angustata, (fig. c, page 85.) Pinnules lanceolate, acute, pinnate, lobes lanceolate, with acute teeth.

Cystea angustata, Smith.-English Flora, vol. iv. p. 288.-English Botany, t. 2790.-Polypodium tenue, Hoffm.-P. rhaticum, Dicks.Aspidium rhaticum, Willd.-Cyathea regia, Roth.

E. anthriscifolia, (Fig. $d$, page 85.) Pinnules ovate lanceolate, pinnate, lobes lanceolate, with obtuse teeth.

Cyathea anthriscifolia, Roth.-Pylypodium anthriscifolium, Hoffm.

Roots numerous, stout, fibrous, black, wiry. Rhizoma tufted, thickly clothed with brown lanceolate membranous scales. Frond erect, or gracefully drooping, a bright cheerful green, somewhat paler beneath, and of a delicate thin texture, convolute in vernation, and rapidly advancing to maturity, of a lanceolate or oblong lanceolate figure; the pinna lanceolate or oblong lanceolate, opposite and alternate, the lower pair shorter than the second. The pinnæ are pinnate, and their pinnules, as will be seen from the varieties enumerated, are of various forms, and are simply toothed, as in $\beta$. dentata, and obtusely lobed and toothed $\gamma$. cynapifolia, or acutely lobed and toothed in $\delta$. angustata and $\varepsilon_{0}$ anthriscifolia. The stem is thin, slender, and delicate, a shining brown in the lower part, green above, very brittle, and of variable length, quite smooth, or with a few pale brown lanceolate scales at the base. The veins are prominent, the mid-vein is waved, and the lateral veins arise alternately, each division again divided into two, three, or four branches, one to each serrature, which terminates in the margin. The sori are circular, and mostly upon the lateral vein under the cleft of the lobes or serratures, which, when numerous, form confluent marginal masses, but mostly they are more scattered. The indusium is a pale thin membrane, attached at its base on the under edge of the sori, and curved over the thecæ like a hood. In a young state it is of a conical shape, more or less elongated, and sometimes remains entire after the plant has reached maturity, as seen in the marginal illustration (fig. e, page 85); more frequently it is split into segments, as seen in fig. $f$, page 84 , but commonly as represented in the plate (fig. 1600.) Generally, however, as the plant advances to maturity, the indusium shrivels up, and is scarcely observable, and at length disappears. The thece are globose, brown, with an elastic beaded ring, at first pale, becoming almost black. 
Habitat.-The fissures of rocks, old walls, and banks, especially in limestone countries; generally distributed throughout the kingdom.

Perennial ; in perfection in July and August.

Few plants are more generally distributed than this very beautiful and delicate Fern, which is aptly called Brittle Fern, from the extreme brittleness of its stem. It prefer's elevated or mountainous districts and a limestone soil, and grows most luxuriantly where it is well supplied with moisture; but though it has this preference as to soil and humidity, it will grow in sandy or loamy districts, and in situations where the supply of moisture is not either great or constant, and we suspect it is to these causes that the great variety of form in the pinnules is owing; influenced, also, no doubt, by the more or less exposed situation in which they have grown. We have found that in limestone districts, when the plants occur in an open situation; and fully exposed to light, with a moderate supply of moisture, that the form of the frond is as represented in fig. 1600, and its indusium short, cut, or ragged, as there drawn, in the same soil and situation; but with a more liberal supply of moisture it is more elongated in its form, and then is the variety $\varepsilon$. anthriscifolia, (fig. $d$, page 85.) When it has grown with an abundant supply of moisture, and in a confined situation between stones or rocks, and excluded from the light, except from reflection, or from above, it becomes still more elongated both in the general form of the frond and the narrow lanceolate shape of the pinnules, and is then the variety $\delta$. angustifolia, (fig. c, page 85.) These changes we have observed both in Scotland and the limestone districts of Derbyshire. The variety $\because$ cynapifolia was collected under a wall in a sandy soil, at Worksop, Nottinghamshire; and $\beta$. dentata in Scotland, under a dry wall on the banks of Loch Lomond, in some of the fronds the sori are so abundant, as when they become confluent to cover the entire back of the pinnæ; in others they are few, and scattered.

We have thus endeavoured to indicate the more marked varieties of forms which are found in this species, but there also occur many intermediate ones, rendering it most difficult to know to which variety to refer them; but we hope by the aid of our illustrations and descriptions the student will find valuable assistance in his investigations. There is, however, another variety found on a wall at Lower Layton, near Walthamstone, Essex, which has been described by Smith, English Flora, vol. iv. p. 290, as Cystea regia, and is figured in English Botany, t. 163, under the name of Cyather incisa; but as 
there appears to be some doubt as to its being a true native plant, We shall here only retain its specific characters, as given in English Botany.

"Frond lanceolate, bi-pinnate, pinnatifid; its segments lobed, obtuse, and beardless; stalk slightly winged ; calyx (indusium) lacerated, and turned to one side."

Cystopteris alpina, Desv.-Babington's British Botany, p. 387.Cystopteris fragilis, var. 4.-Newman's British Ferns, p. 15\%.

The figure given in Newman's British Ferns, p. 157, as well as that in English Botany, greatly resembles specimens which we have collected in the Alps of Switzerland.

2. C. monta'na, Link. (Fig• 1601.) Mountain Bladder-fern. Frond smooth, tri-pinnate, triangular, deltoid; the lower pair of pinnæ much longer than the others; pinnæ lanceolate, or oblong; the pinnules lanceolate, or oblong, pinnated, and their lobes deeply cut and toothed, their apex emarginate, or bi-dentate; lateral veins pro. minent, terminating in the margin.

Newman's British Ferns, p. 159.-Polypodium montanum, Hacuke. -Aspidium montanum, Swartz.-Cyathea montana, Roth.

Root fibrous. Rhizoma tufted, scaly. Fronds erect, or slightly drooping, of a triangular deltoid form, from the lower pair of pinnæ, which are always opposite, or neariy so, being much larger than any of the others, indeed sometimes as large and as long as the whole of the rest of the frond. The pinnæ are pinnate, the pinnules alternate and stalked, of an oblong lanceolate form, pinnatifid, with the lnwer lobes stalked, all are more or less deeply cut and toothed, the apex of each division being notched or bi-dentate, and the lateral veins terminating between them; the pinnules, though distinctly stalked, are connected one with the other by a narrow wing, which runs on each side of the mid-rib. The texture of the frond is thin and delicate, with the ribs and lateral veins prominent; they arise alternately, and are branched or simple, and terminate in the margin between the cleft at the apex. Sori large for the size of the plant, circular, and though often much crowded, still they do not one run into the other in confluent masses; each retains its individual form, arising from the lateral veins near the margin of the frond. Indusium pale, thin, membranous, of a pyramidal form, attached by its base to the lateral vein, and its apex pointing towards the cleft of the serrature, its margin is at first entire, bending over the thecæ like a hood. It soon, however, becomes jagged or torn on the margin, and 



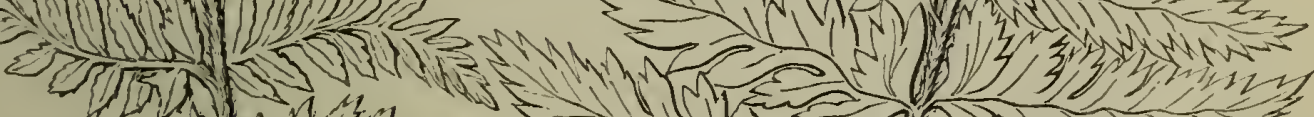

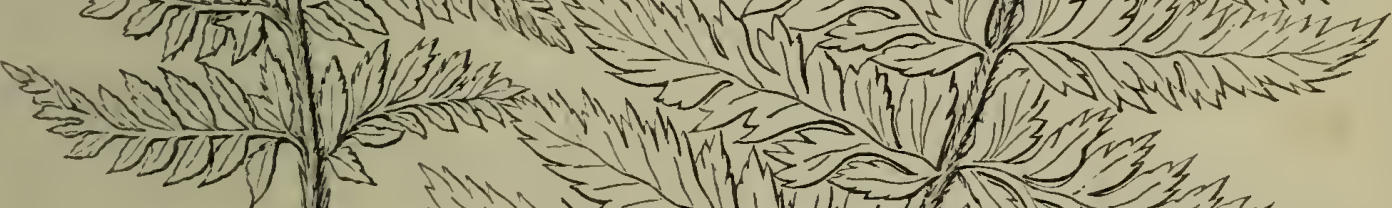
सTIST)

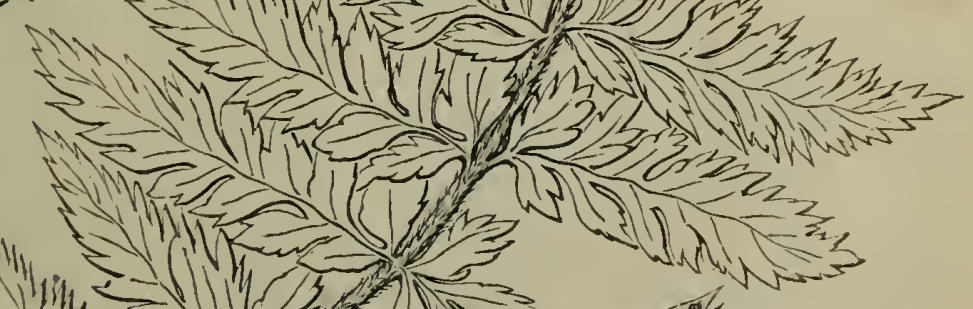



sbortly shrivels up and disappears. Theca dark brown, with an elastic beaded ring. Stem long, slender, smooth, or with a few scattered brown scales towards the base; generally the stem is much longer than the frond, rarely shorter, green above, and brown and shining at the base.

Habitat.-Ben Lawers, Forfarshire, Scotland.-Mr. Witson.

Perennial; in perfection in August.

This beautiful and distinct species of Cystopteris was found by $\mathrm{Mr}$. Wilson, in August, 1836; but not possessing any native plants, we have made the drawing from Swiss specimens, and drawn up the description from the same. It is not a very common, though generally distributed plant in Switzerland, and on the higher mountains of the Appennines in Italy, and is readily distinguished from all others.

Our illustration is drawn the full size of an ordinary plant, and represents the pinnæ all nearly opposite. It is, however, often found with the upper ones alternate, and the first and second pair only opposite.

\section{GENUS XIV. POLYSTI'CHUM.-Rотн. Shield-fern.}

Gen. Char. Sori roundish clusters, scattered. Indusium orbicular, or nearly so, attached by the centre only.

1. P. Lonchi'tis, Roth. (Fig. 1602.) Rough Alpine Shield-fern, or Holly-fern. Fronds linear lanceolate, simply pinnate; pinnæ lanceolate, falcate, acute, ciliato-serrated, very rigid, the upper edge auriculated at the base, rounded on the lower, the under side scaly.

Newman's British Ferns, p. 163.-Polypodium Lonchitis, Linn.-English Botany, t. 797.-Aspidium, Sw.-English Flora, vol. iv. p. 277.-Hooker, British Flora, ed. 4. vol. i. p. 383.

Roots fibrous,'wiry, strong, long, black. Rhizoma thick tufted, and clothed with brown thin membranous lanceolate scales. Fronds from six to twelve inches long, of a linear lanceolate figure, and simply pinnate, very rigid, and a somewhat leathery texture, a full smooth shining green on the upper side, paler beneath, and more or less clothed with narrow lanceolate pale membranous scales. Pinnce alternate, more or less thickly crowded, and overlaying each other; 
each is on a short footstalk, of a lanceolate somewhat crescent-shape, curved upwards; the base on the upper margin is auriculated with an ovate lanceolate lobe, the lower is smooth, and tapering to the footstalk. The lower pinnæ are lobed on both sides at the base, all are toothed on the margin with acute teeth, terminating in a bristle point. The mid-rib is straight, or slightly waved. The lateral veins are alternate, three-branched, the two lower ones terminate in each tooth and the margin, the upper one terminates before it reaches the margin, and bears about its middle a circular sorus; the auricle is furnished with a mid-rib and lateral vein of its own, which are arranged in the same manner as the others. Sori circular, numerous, becoming confluent, and forming a continuous line on each side about midway between the mid-rib and margin; the sori are most numerous on the upper pinnæ, the lower are often without or loosely scattered over with them. Indusium circular, attached to the lateral veins by a short central cord, around which the thece arise, which are globose, numerous, a deep brown colour, encircled with a beaded elastic ring. Sporules ovate, angular, minute.

Habitat-Shady clefts of rocks and stones; on the highest mountains of Scotland and Wales; Falcon Clints, Durham; rare in lreland.

Perennial; in perfection in September and October.

This very beautiful and remarkable Fern is the most hardy of our species, growing on the most lofty of our mountains, and in the most barren and exposed situations, luxuriating in the blast and flourishing only in the pure atmosphere of those lofty regions; hut it is not a very common plant in any situation. It is the most rigid of our species, and so sharp and hard are the spines of its teeth, as to well entitle it to its common name of Holly-fern.

The figures illustrative of this species are drawn of the natural size and proportion. Fig. a represents a frond from the mountains in Wales, in which it will be seen the auricle of each pinnæ is turned behind the one before it; not unfrequently, however, it is found with the auricle turned forward instead of backward. The other frond (fig. b) is drawn from a specimen collected near the top of Ben Lomond, Scotland. Both are represented in the position in which they were growing. Fig. $c$ represents one of the pinnæ larger than natural, to show the mode of the distribution of the veins and the position of the sori, as they are attached to the lateral veins. Fig. $d$ is a pinnæ the natural size, and shows the form of the indusium, 


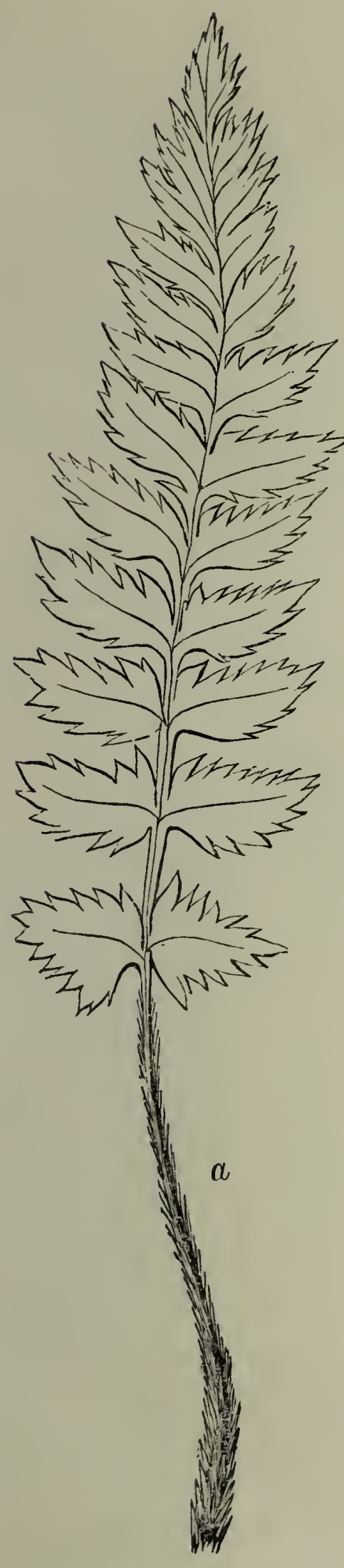

surrounded by the thecæ, one of which is represented above, with its beautiful elastic beaded ring, and the minute oblong angular sporules highly magnified. The stem, as will be seen, is short, and thickly covered with brown lanceolate membranous scales, which are also frequently more or less scat. tered in the lower part of the rachis.

It is not unfrequent in the Swiss Alps, where both the forms are found, and the difference, as far as we have observed, seems to be caused by the more rigid one growing in a dryer and more exposed situation than the other.

2. P. aculea'tum, Roth. (Fig. 1603, and e, page 92.) Prickly-fern. Frond bi-pinnate, lanceolate; pinnæ lanceolate; pinnules lanceolate, with a spinous point; the lower ones stalked, and entire, or slightly auricled on the upper side at the base, the rest decur. rent, or united at the base, and all standing at an acute angle with the mid-rib of the pinna.

Newman's British Ferns, p. 169.

B. lonchitioides. (Fig. $a$ annexed, $b, c$, page 92.) Pinnæ simple, more or less deeply toothed and auricled on the upper side at the base.

Aspidium lobatum, $\beta$. lonchitioides.Hooker. Hooker's British Flora, ed. 4. v. i. p. 384.-A. aculeatum. $-\beta$. English Flora, p. 277.

$\gamma$. lobalum. (Fig. $d$, page 92.) Pinnæ pinnatifid, the lower pinnules stalked, not auricled at the base, the rest decurrent.

Polypodium lobatum, Hudson.-Aspidium.-English Botany, 


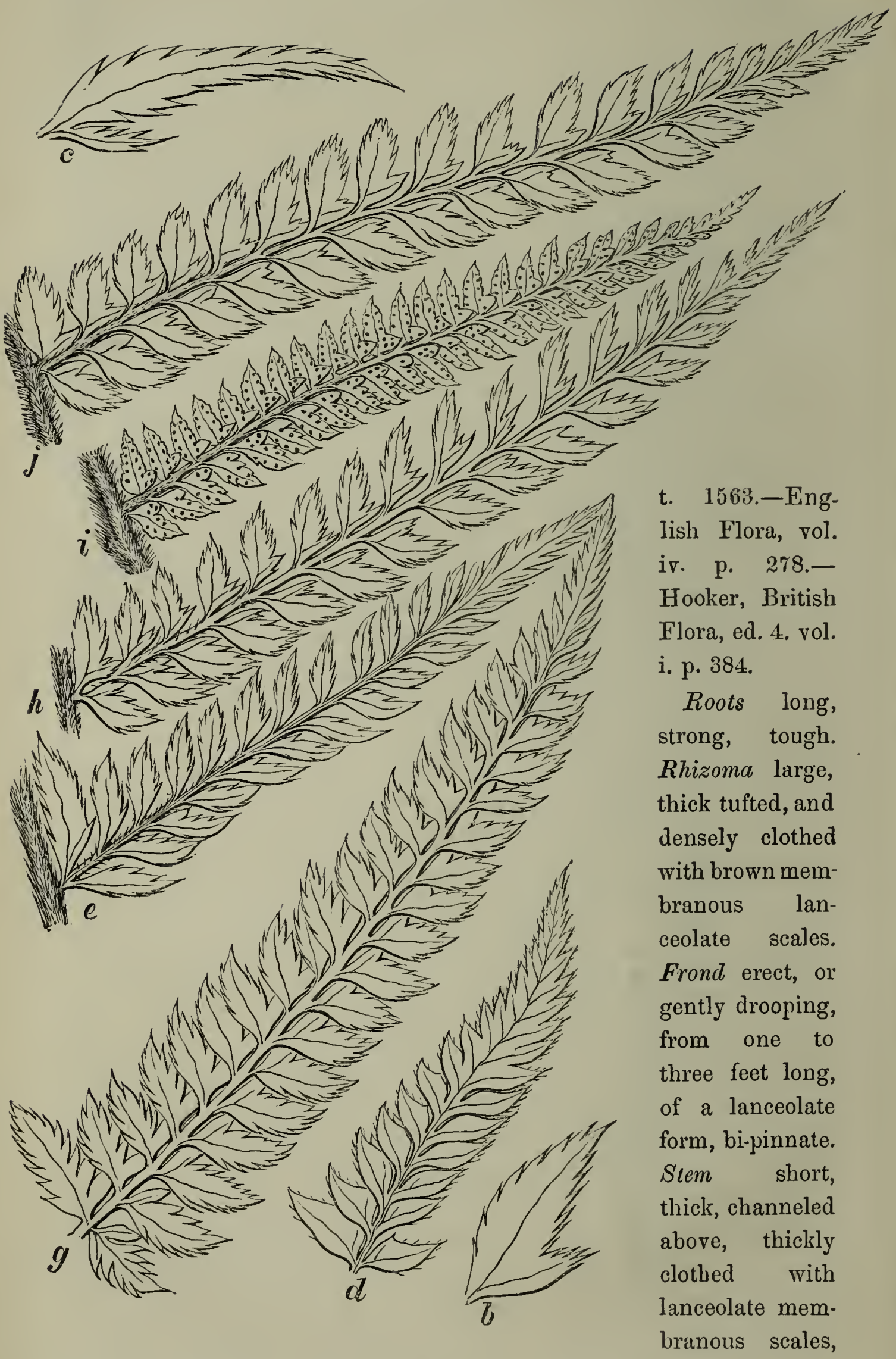

of rarious length and size, as well as the rachis often eren to the 
end. The pinne are pinnate, of a lanceolate form, and stand off from the rachis nearly at a right angle. They are of a tough leathery texture, very rigid, smooth and glossy on the upper surface, mostly of a dark green, occasionally paler; the under side is more or less thickly clothed with hair-like scales, a pale dull green, and mostly studded over with small circular depressions, a character which we have not observed in the following species, when the pinnæ are entire and toothed, as in fig. $a$, page 91 , or toothed and auricled at the base, as in fig. $b$ and $c$, page 92 , which are detached from the rachis, it is the variety $\beta$. ; when they are pinnated at the base, and lobed upwards, as in fig. $d$, page 92 , it is the variety $\gamma$. ; when, however, the pinnæ are more divided, and the pinnules only united at the upper part and point, as in fig. $e$, page 92 , it is the $P$. aculeatum. The pinnules are ovate lanceolate, with a sharp spinous point, and serrated with sharp rigid bristle pointed teeth. They stand off from the main stem of the pinna in a more acute angle than the following species. The first upper pinnule is mostly much larger than the rest, and stands behind the pinna above it, thus forming a continuous

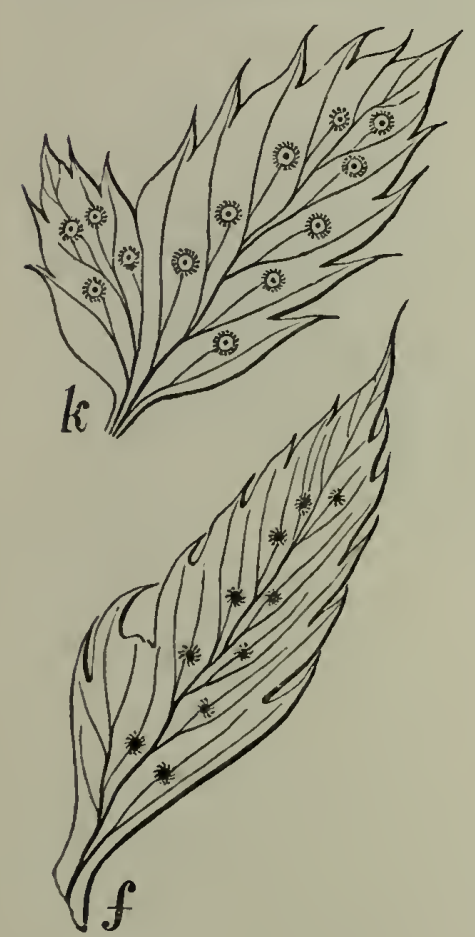
linear sorus on each side the rachis. The lower ones are sometimes auricled on the outside at the base, as in fig. $f$; ; but frequently they are without the mid-rib of the pinnules, slightly waved, terminating in the point. The lateral veins alternate, two or three branched, the anterior one bearing the sorus, and terminating before reaching the margin, the other terminate in the teeth; the auricles have a separate mid-rib, and lateral veins. Sori numerous, confined to the upper part of the frond, the lower ones very rarely bearing any. They are situated about mid.way between the margin and mid-rib, circular, mostly dis. tinct, rarely confluent. Indusium circular, attached to the lateral vein by a short central stalk, around which the numerous thecæ arise. As the plant advances to maturity, the indusium curls up, shrivels, and falls away, leaving the thecæ naked, which are then dark brown, sometimes almost black clusters.

Habitat.-Hedges, banks, and shady situations; common.

Perennial ; in perfection in August and September. 
The various forms which this plant assumes in the shape and division of its pinnules render it one of extreme difficulty to define. It is connected so intimately on the one hand with the former species, $\boldsymbol{P}$. lonchitis, as will be seen by the illustration (fig. $a$, page 91, which is of a hard rigid texture, though not so much so as $P$. lonchitis; but this, together with pinnules, (fig. $b$ and $c$, page 92,) intimately connect them. On the other hand, fig. $d$, page 92 , it will be seen, as well as the pinnæ in the plate, (fig. 1603), show the frond more or less pinnated into simple and slightly auricled pinnuies; and the pinna (fig. e, page 92,) shows nearly all the pinnules separated, and intimately connects it with the following species, $\boldsymbol{P}$. angulare; and the more this species approaches $P$. angulare the more delicate it becomes, and is less rigid in its texture. The plates (figs. 1602 and 1603) illustrating these two species are drawn from plants exhibiting the ex-

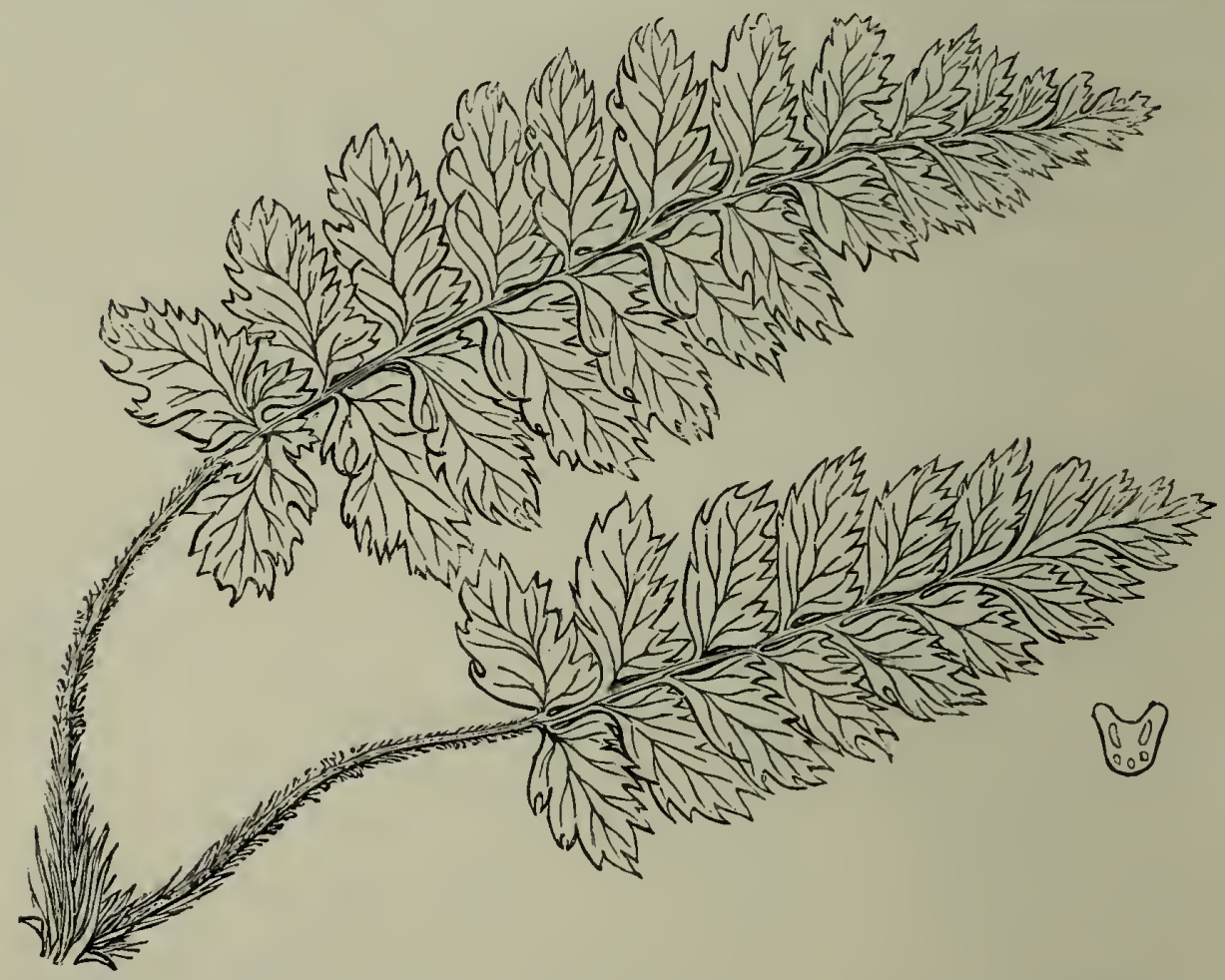

treme peculiarities of each, in order to show the marked difference between them; and if it was not for the many intermediate forms connecting them so intimately, there would be no difficulty in defining their limits; but the student will find their connecting links so similar, as to consider them, as we often have, all varieties of one species; but when there is in the extremes so great a difference, as we have shewn in our plates, it appears best, until our knowledge of the limits of species is more defined, to keep them under two heads, connecting them by the varieties.

The above sketches are of young frouds of $\boldsymbol{P}$. aculeatum, and a 
transverse section of the stem, showing fire bundles of ducts, which run through its whole length to the pinnules.

The vernation of this plant is extremely beautiful; it arises from the rhizoma, closely curled inwaris; but when it is more expanded, it droops backward, while the extremity still retains its tendency to curl inwards, thus forming a double curve, and having a most graceful appearance.

3. P. angula're, Newman. (Fig. 1604.) Angular pinnated Fern. Frond bi-pinnate, lanceolate; pinnæ lanceolate; pinnules ovate lanceolate, obtuse, all stalked, (except a few at the point), and auriculated on the upper side at the base, and all standing at an obtuse angle with the mid-rib of the pinna.

Newman's British Ferns, p. 173.-Aspidium ıngulare-Fnglish Botany, t. 2776.-Hooker, British Flora, ed. 4. vol. i. p. 384.English Flora, vol. iv. p. 278.

Root long, strong, tough. Rhizoma large, thick tufted, and thickly clothed with large brown membranous lanceolate scales, and very numerous small ones. The stem of variable length, mostly about one-fourth the length of the frond, thick and channeled above, very scaly, as well as the rachis. The frond gracefully drooping, from one to three feet long, of a lanceolate form, bi-pinnate. The pinnce linear lanceolate, or lanceolate pinnate, the lower ones standing at right angles with the stem, the upper curving towards the point, a bright shining green on the upper side, pale dull greyish green beneath, and more or less scattered over with slender hair-like scales, as well as the main rib; but not unfrequently the rachis is very scaly, and the mid-rib of the pinna and pinnules quite smooth. The pinnules are ovate lanceolate, arising at a more obtuse angle from the mid-rib than in the last species; sometimes they stand at almost a right angle, at others a very acute, auricled on the upper side at the base, which is, however, very variable in size; occasionally it is deeply cut to the mid-rib, and this accompanied with the deep cut teeth, as in fig. $g$, page 92 , it becomes almost pinnated, but usually they are of the form of fig. $h, i, j$, page 92 . The teeth are pointed with soft slender bristles, or hairs, not rigid, and spiny, as in the last species. The terminal bristle of the pinnule and the auricle is the strongest; the upper pinnule of each pinnæ is larger than the others, but rarely so large as in $P$. aculeatum, and often it is scarcely larger than the one next it. The mid-vein is wared, and terminates in the apex; the lateral veins arise alternately, are mostly forked, sometimes three 
branched, which terminate in the teeth or margin; but the anterior branch which bears the sorus terminates with the sorus, and but rarely extends beyond it. Fig. $k$, page 93 . The sori are numerous, circular, of a pale nut brown, often becoming confluent. Indusium circular, attached by a short central stalk to the lateral vein, becoming curled up on its edges all round, but remains attached after the thecæ are all burst.

Habitat.-Under hedges, woods, and sheltered places; common.

Perennial ; in perfection in August and September.

This is an extremely beautiful and elegant plant, but varies much in its size and developement, according to the more or less favourable situations for its growth, and, indeed, fronds from the same rhizoma vary very greatly. Figs. $i$ and $j$, page 92, are both from the same rhizoma, and appear to vary from the circumstance of the early part of the summer being very dry, so that from the situation of the plant it got but a spare supply of moisture, and the fronds were small, though bearing an abundant quantity of sori; the season then became wet, the plant was abundantly supplied with moisture, so that new life appeared given to it, and the fronds, which were retarded in their growth, became much larger and more developed than the others, but without sori ; one of its pinna is represented in fig. $j$, page 92. This example is one amongst the causes of variation; add to this the soil, the exposure to the blast of mountain currents, \&c., and some clue is given to the diversities of form that are found.

\section{GENUS XV. LAS'TRAA.-Borg. Crested-ferns.}

Gen. Char. Sori roundish clusters, scattered. Indusium reniform.

1. L. Thelyp'teris, Presl. (Fig. 1605.) Marsh-fern. Frond lanceolate, pinnate; pinnæ lanceolate, the two lower pair rather shorter than the others, without glands; pinnules ovate, acute, the margins curved inwards; sori midway between the mid-rib and margin ; rhizoma creeping.

Newman's British Ferns, p. 183.-Aspidium.-English Flora, vol. iv. p. 273.-Hooker, British Flora, ed. 4. vol. i. p 385.

Roots black and fibrous, downy. Rhizoma long, slender, creeping, widely spreading, black. Frond erect, slender, of a delicate texture, and bright cheerful green, paler beneath, from one to two feet high, sornetimes not more than a few inches, very fragile, quite smooth, or slightly hairy on the under side, but without glands, of a lanceolate 


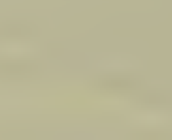

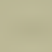
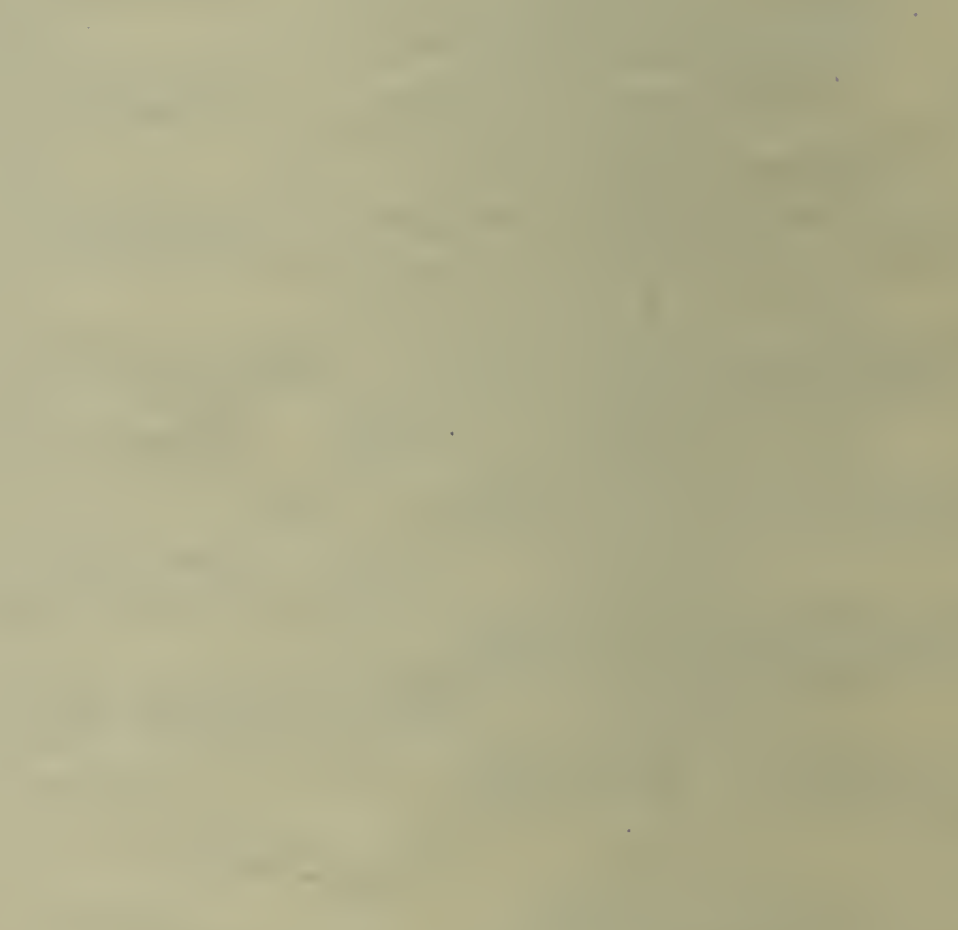
figure, with the first and second pair of pinnæ shorter than those above them. Pinnce linear lanceolate, opposite or alternate, the

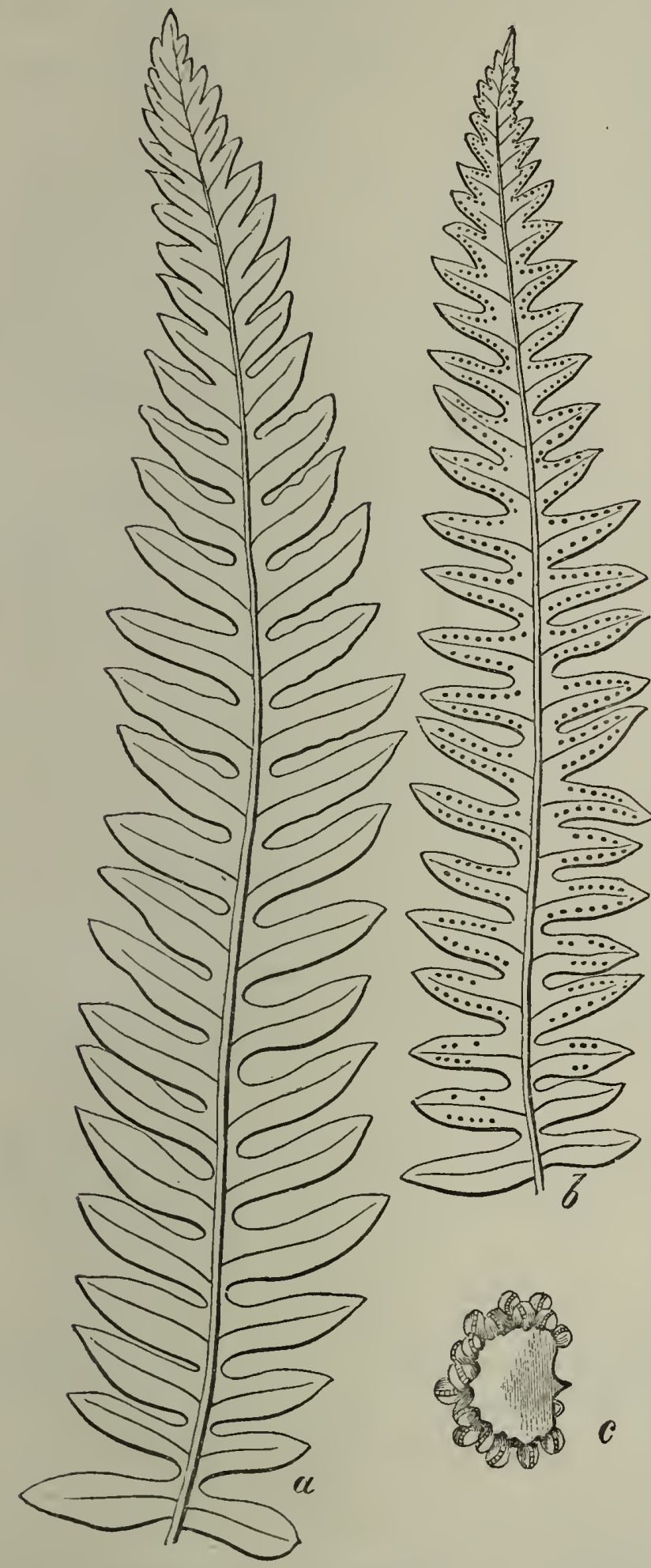
pinnules ovate, acute, or obtuse at the point, the margin rolled inwards, entire, or slight ly waved or serrated, the pair nearest the rachis larger than the rest, and sometimes slightlylobed. Lateral veins alternate, forked soon after leaving the mid-rib, and terminating in the margin; occasionally they are simple; each branch bears a nearly circular sorus about mid-way between the mid-rib and the margin, soon becoming confluent, and forming a continuous line, which at length covers the whole back of the pinnules. Theca small, globose, pale brown, shining, encircled with a beaded elastic ring. Spo. rules ovate, minute. Indusium very small, flat, reniform, pale, almost white, soon pushed on one side by the thecæ, and disappearing. Stem slender smooth, thick, and compressed at the base with two bands of ducts, (fig. $a$ 1606,) rounded and more slender above, channeled, and the two bands of ducts united into one of crescent form (fig. $b$ 1606). 
Habitat.-Marshy and boggy places; not unfrequent in England; very rare in Scotland. "Among woods and bushes in the low part of Portmore Park; on the side of Lough Neagh, county Antrim, $M r$. Templeton; near Lough Carra, county Mayo, Mr. J. Ball; marsh near Mucruss, Mr. Mackay, Ireland.

Perennial ; in perfection in July and August.

The description above given is of a fertile frond; but in situations where this plant grows abundantly there are also besides the fertile, numerous barren fronds, but these only differ from the others in being larger and seemingly more developed. The marginal figures will better illustrate this difference than any description. Fig. $a$, page 97 , is a pinna of a barren frond, and fig. $b$ of a fertile frond. Both are drawn the natural size of ordinary grown plants; the latter shows the position of the sori, and fig. $c$ represents one of the sori separated and magnified to show the shape, and the indusium surrounded with the numerous thecæ. The plate (fig. 1605) illustrates the entire frond one-third less than the natural size. The detached pinnule drawn larger than natural is to show the distribution of the lateral veins and the position of the sori. The margin on one side is shown as it generally is rolled back; the other margin is unrolled to show more clearly the distribution of the veins and their termination in the margin.

2. L. oreop'teris, Presl. (Fig. 1606.) Mountain Fern. Frond elongate, lanceolate, pinnate; pinnæ lanceolate, the lower ones very short, sub-triangular, scattered over on the under side with resinous glands; pinnules flat, oblong, obtuse, entire, those next the rachis longest; sori marginal ; rhizoma tufted.

Newman's British Ferns, p. 187.-Aspidium.-English Flora, vol. iv. p. 273.-Hooker, British Flora, ed. 4. vol. i. p. 385.-Polypodium.-English Botany, t. 1019.

Roots numerous long tough wiry fibres. Rhizoma thick, tufted, scaly. Fronds mostly very numerous, circinate in vernation, but immediately they unroll, the pinnæ stand off at right angles with the rachis, assuming much the appearance of an ostrich feather. When the fronds are fully expanded they are of an elongate lanceo-

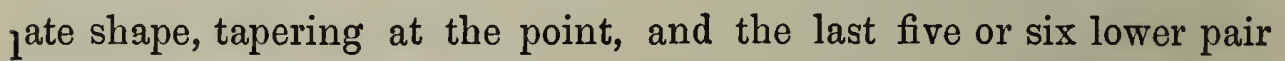
much smaller than the rest of a triangular figure; the upper one is of a linear lanceolate shape, pinnate, with simple, opposite, or alternate pinnules; the lower pair mostly much larger than the rest, oblong, ovate, obtuse at the point, flat, the margins entire, or waved, 


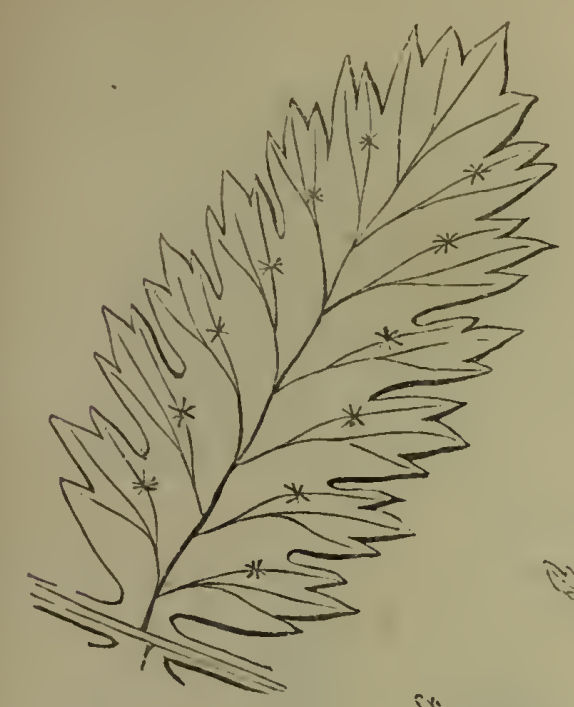

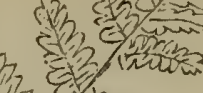

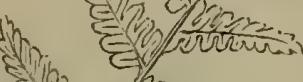

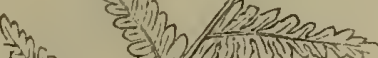

Enm

हैxits

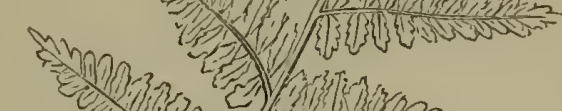

namon

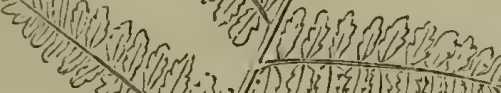

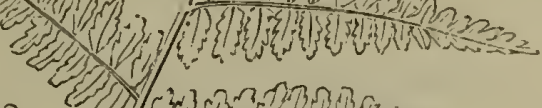

(20)

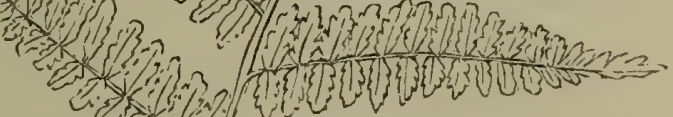

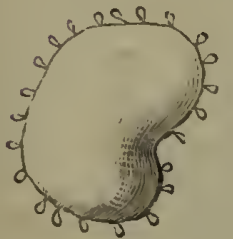

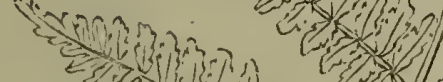

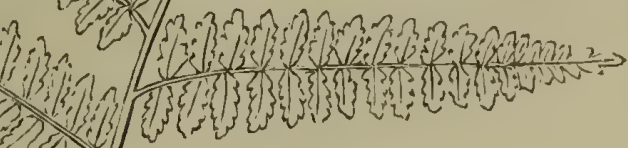

कीजि

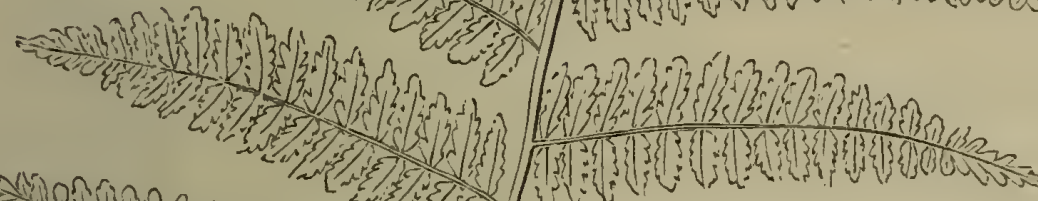

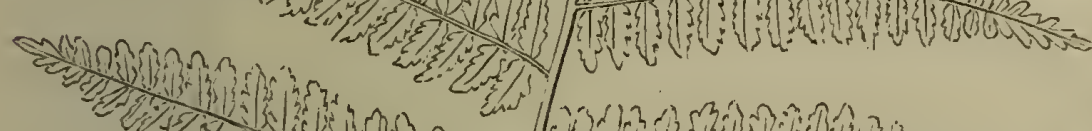

- 2 in

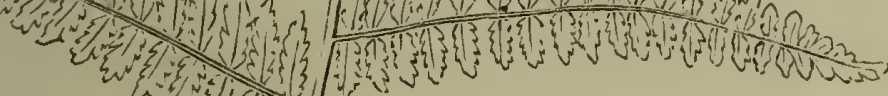

क्णीकी

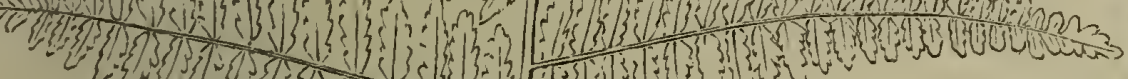
2.

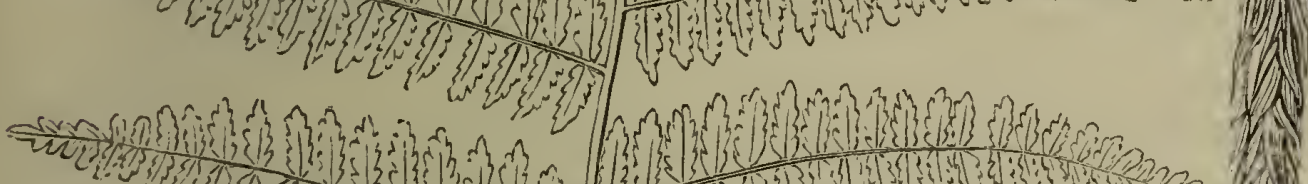
क्य,

vels

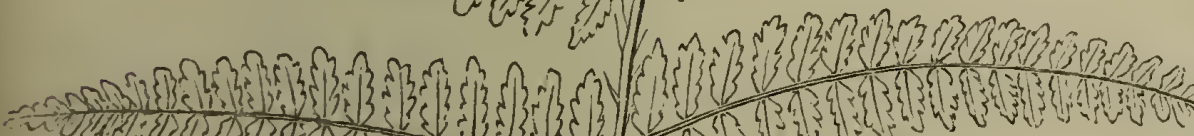

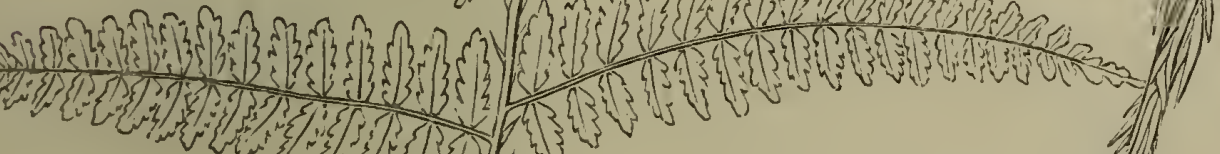
3)

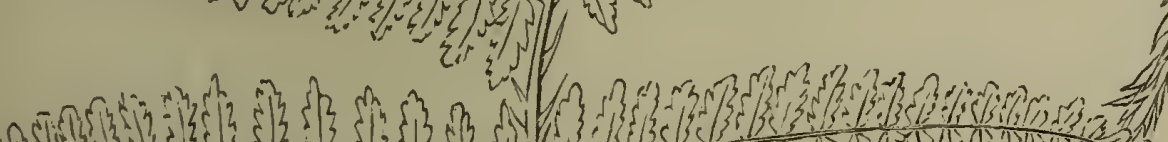

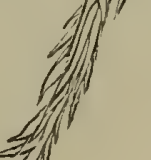

- ma

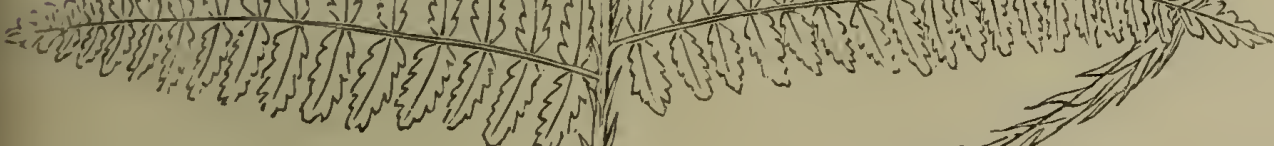

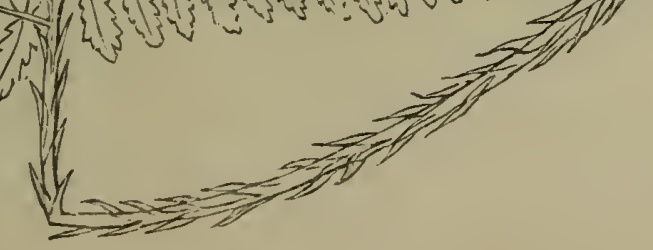


(n)

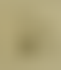

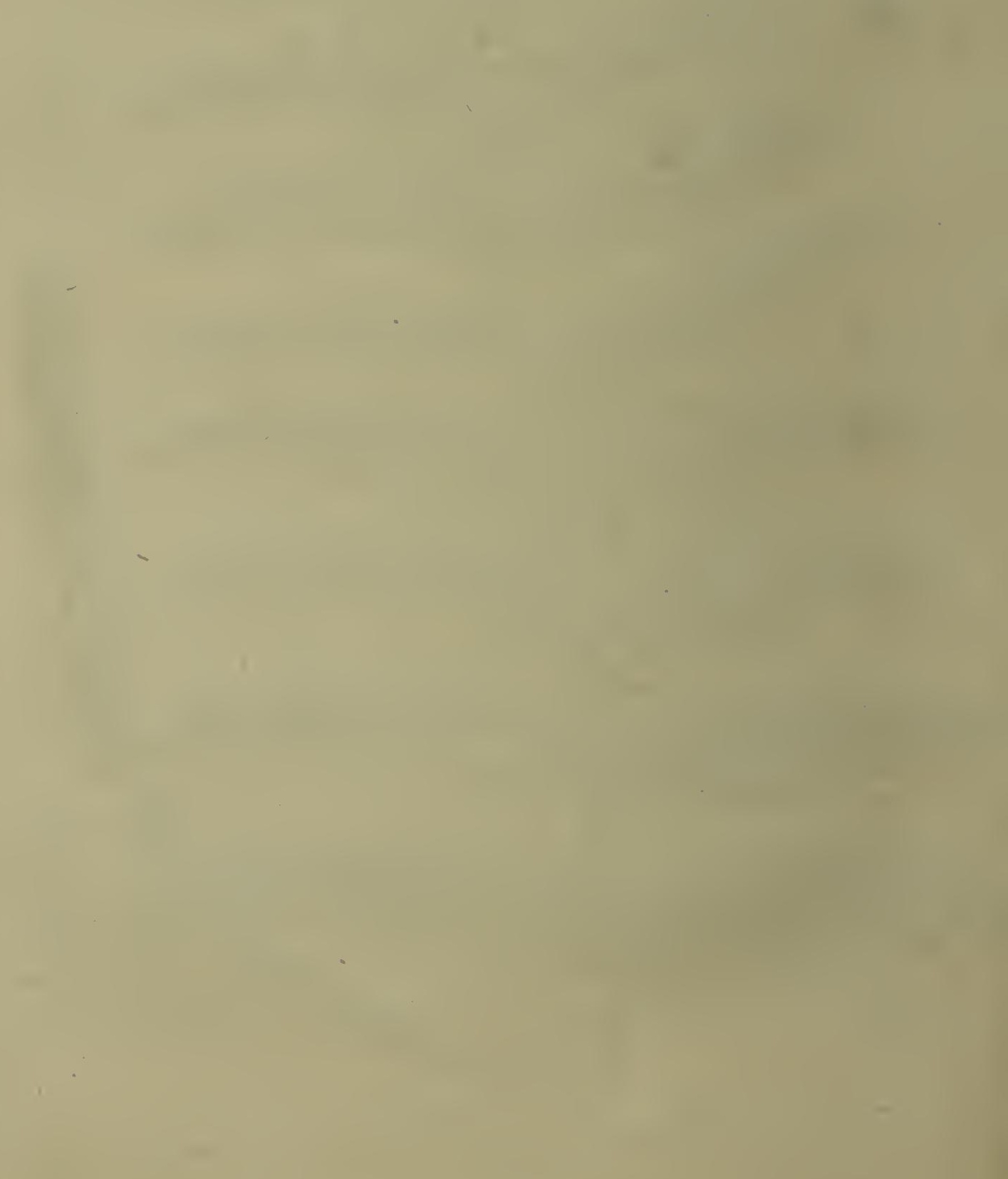


rarely sub-crenated, of a smooth bright green above, dull beneath, and scattered over more or less profusely with minute resinous glands and soft pubescence : these glands emit a peculiar, but not very pleasant odour. Lateral veins simple, sometimes branched, each branch bearing near its extremity a circular sorus, and terminating before reaching the margin. Sori numerous, eircular, a pale brown colour, soon becoming confluent. Indusium small, pale, thin and

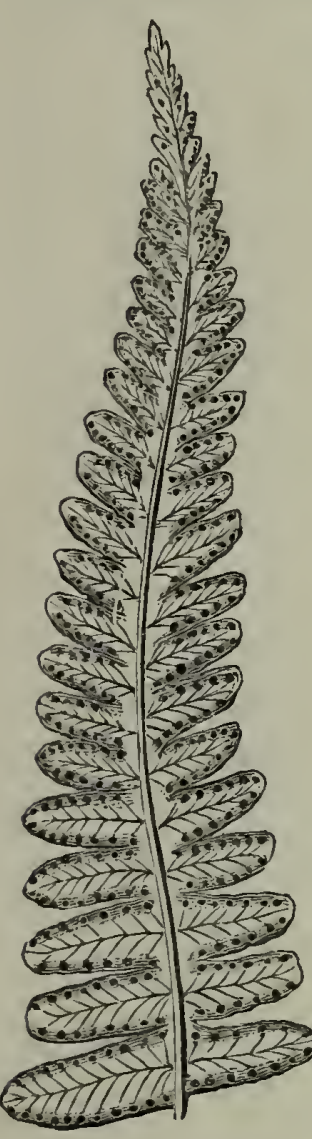
membranous, sub-reniform, but soon becoming curled up, and without any particular form, often even in a very early stage, the indusium is fallen away, and it has the appearance of a Polypodium. Theca small,'globose, with a beaded elastic ring. Sporules minute, ovate. Stem short, rounded at the back, channeled in front, somewhat scaly, and more or less hairy, as well as the rachis.

Habitat. - Mountainous districts in heathy places, frequent; not very common in low situations; rare in Ireland.

Perennial ; in perfection in July and August.

When these and the following species are seen together, the student will find no difficulty in distinguishing one from the other. The peculiar form of the frond of this species renders it very distinct from all other of our Ferns.

Our plate illustrative of this species (fig. 1606) is drawn one-third the size of an ordinary plant. The Edetached pinnule represented larger than natural, shows the distribution of the lateral veins and the position of the sori, with the indusium in the centre. The marginal illustration is a pinna represented the natural size, and showing also the distribution of the lateral veins and position of the sori near the margin. The figure under it is one of the sori removed, and delineated as seen through a magnijying power, showing the form of the indusium, with its jagged margin surrounded by crowded thecæ.

3. L. rig'ida, Presl. (Fig. 1607.) Hard Fern. Fronds nearly erect, lanccolate, bi-pinnate, the upper surface scattered over with sessile glands; pinnæ lanceolate; pinnules oblong, obtuse, stalked, deeply lobed, each lobe serrated at the end with two or three obtuse teeth; 
stem very scaly; indusium reniform, with a fringed glandular margin.

Newman's British Ferns, p. 191.-Aspidium rigidum.-English Botany Suppl. t. 2724.-Hooker, British Flora, ed. 4. vol. i. p. 385.Polystichum strigosum, Roth.-Polypodium fragrans, Linn. (?)

Roots long, fibrous. Rhizoma large, thick tufted, scaly. Stem very thick at the base, and very thickly clothed with large reddish brown membranous scales, which extend, but of a much smaller size, nearly the whole length of the rachis. Frond lanceolate, or triangular lanceolate, nearly erect, bi-pinnate, the pinnæ lanceolate, and standing at nearly right angles with the rachis, alternate or opposite. Pinnules oblong, obtuse, each standing on a short broad footstalk, cut into lobes in a pinnatifid manner, and each lobe mostly three-toothed, the end sometimes two-toothed, and the teeth triangular, with an obtuse not spinous point. The mid-vein waved, giving its lateral brunches alternately, which are two or three branched, each branch going to a tooth, but terminating before reaching the margin; the upper branch, which is the longest, bears about its middle and midway between the mid-rib and margin, the sori, which are circular or sub-reniform clusters, becoming confluent, and covering nearly the whole of the underside of the pinnule. Indusium reniform, lead coloured, attached to the lateral vein by a short stalk at the notch, its margin is more or less fringed with stalked glands, and the upper surface of the frond is studded over with sessile glands, which emit a peculiar odour, and give a somewhat glancous hue to the plant.

Habitat.-Limestone rocks in mountainous districts. Near the foot of the mountain, Ingleborough, Yorkshire - The Rev. W. J. Bree. Arnside Knot, Hutton Roof Crags, and Falcon Knot, Westmoreland. -Rev. G. Pinder and Miss Beevor. Near the top lock of the Lancaster and Kendal Canal, Lancashire.-The Rev. T. Smythes.

Perennial; in perfection in July.

This beautiful Fern has from its erect growth and form of frond a good deal of the habit of L. Filix-mas, from which, however, there will be no difficulty in distinguishing it by its glandular surface and glandular fringed indusium. It also approaches in its stalked pinnules the following species, $\boldsymbol{L}$. erosa; but this is without glunds in any of its parts: its sori are arranged nearer the mid-rib. The plant is very much larger, and its stem much shorter.

The plate illustrative of this species is drawn about one-third the natural size. Its pinnæ are represented less crowded than it is often 


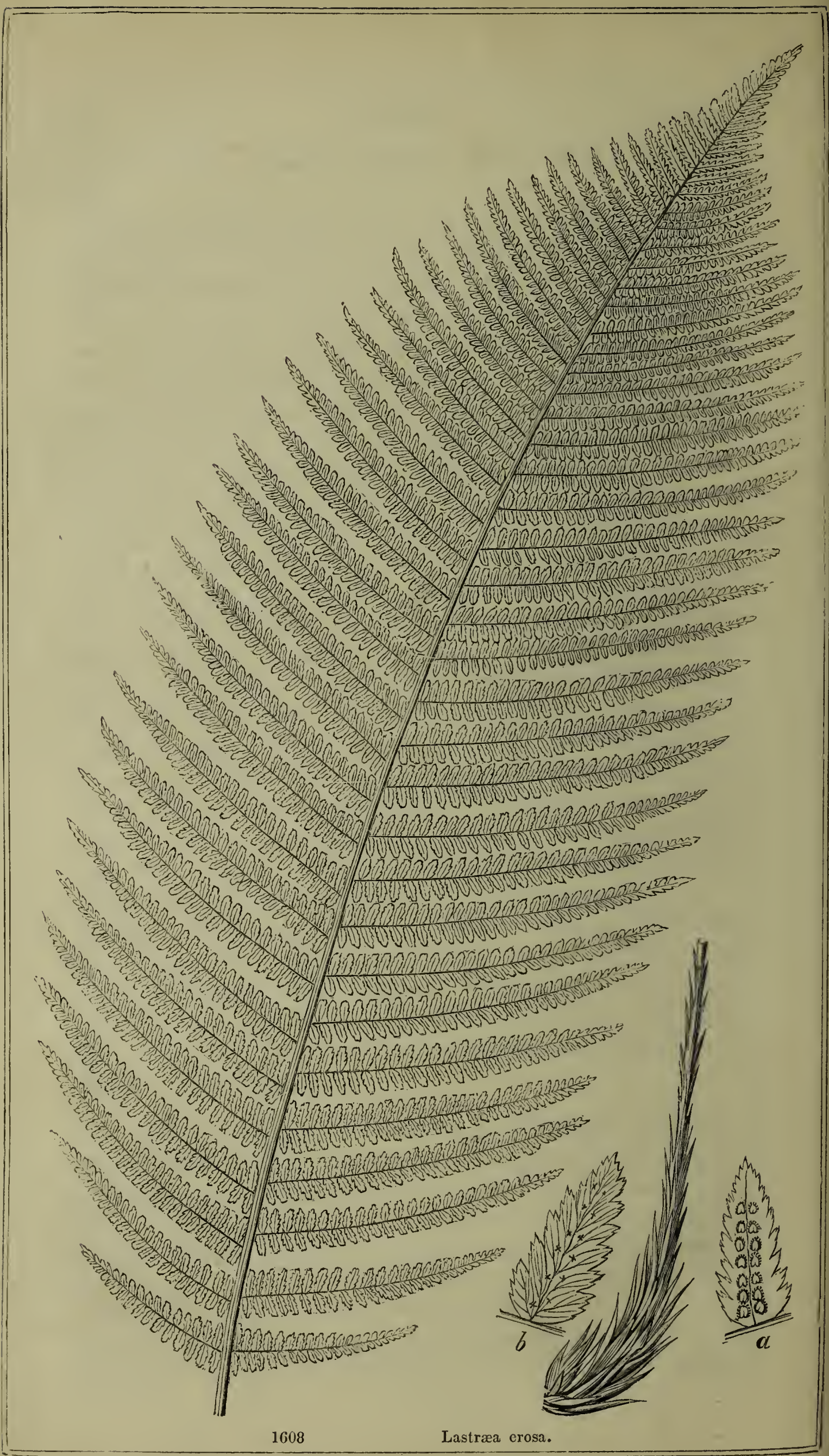


found, and it frequently is less tapering at the top of the frond. It is also not uncommon to find the frond more lanceolate in form, having the three or four lower pinnæ one smaller than the other, the lowest one sometimes being almost triangular; but these are young, and not fully developed fronds. The detached pinnule is drawn larger than natural, in order to show more clearly the divisions of its lobes, the form of its teeth, the arrangement of its lateral veins, and the situation of the sori upon them. Below this is represented one of the indusiums also magnified, to show its glandular fringed margin.

4. L. ero'sa, Deakin. (Fig. 1608.) Knawed Fern.

Frond oblong lanceolate, acute, bi-pinnate; pinnæ linear lanceolate, pinnate; pinnules oblong, acute, lobed, and serrated, with acute teeth, distinct, and mostly distant from each other, and notched at the base, the first superior one longer than the others; lateral veins three or four branched, the anterior branch bearing a circular cluster of thecæ, and from six to fourteen on a pinnule; indusium orbicular. reniform, flat, the margin uneven.

Aspidium Filix mas, $\beta$. erosum, Doll. rhein. Flor. p. 16.-A. depastrum et $A$. erosum, Schk. cypt. t. 45. et 51.-Polypodium Heleopteris, Borkhausen in Roem arch. 1, 3. p. 19.

Roots long, tough, branched, a dark brown colour. Rhizoma elongate, scaly. Frond from six to eight feet high, elegantly droop. ing. The stem is bent and much enlarged at the base, and very thickly slothed with ovate lanceolate thin bright brown coloured membranous scales The points are mostly much elongated, slender, and the sides often split into narrow segments. The upper part of the stem, rachis, and rib of the pinnæ, are more or less scattered over with very narrow hair-like scales, of a paler colour. The naked stem is less than a third of the whole length of the frond which is of an oblong lanceolate form, with an acute point, and the plant now before us measures sixteen inches across its widest part, each pinnæ being near eight inches long, and one and half wide. The pinnce are linear lanceolate, pinnate. The pinnules oblong, acute, or linear lanceolate, distant from each other, and for the most part distinctly spirated and notched on each side at the base, so that they stand on a short broad footstalk: this is the case with the first six to ten pair, the rest are notched on the upper side only, except those forming the point, and are connected by a narrow wing one to the other; all are deeply cut into lobes, and more or less deeply toothed, or lobed at the base and toothed towards the point. The first superior 
pinnule is longer and narrower than the first lower one, which is auriculated on the under side at the base. The mid-rib is somewhat waved. The lateral veins arise al. ternately, and give off a branch from near the base towards the mid-rib, which bears the sori near its base; two others, sometimes three, arise alternately, but do not bear sori, and terminate before reaching the margin in an elon. gated bulb, which forms a scar on the upper surface. The lateral veins towards the point of the pinnules are simple or forked, but these do not bear sori, and it would seem as though it was an exception to the arrangement for a lateral branch with one branch only to bear sori; each pin. nule bears from six to fourteen sori, arranged on each side the mid.rib, and though the thecæ extend beyond the margin of the indusium, they do not seem to
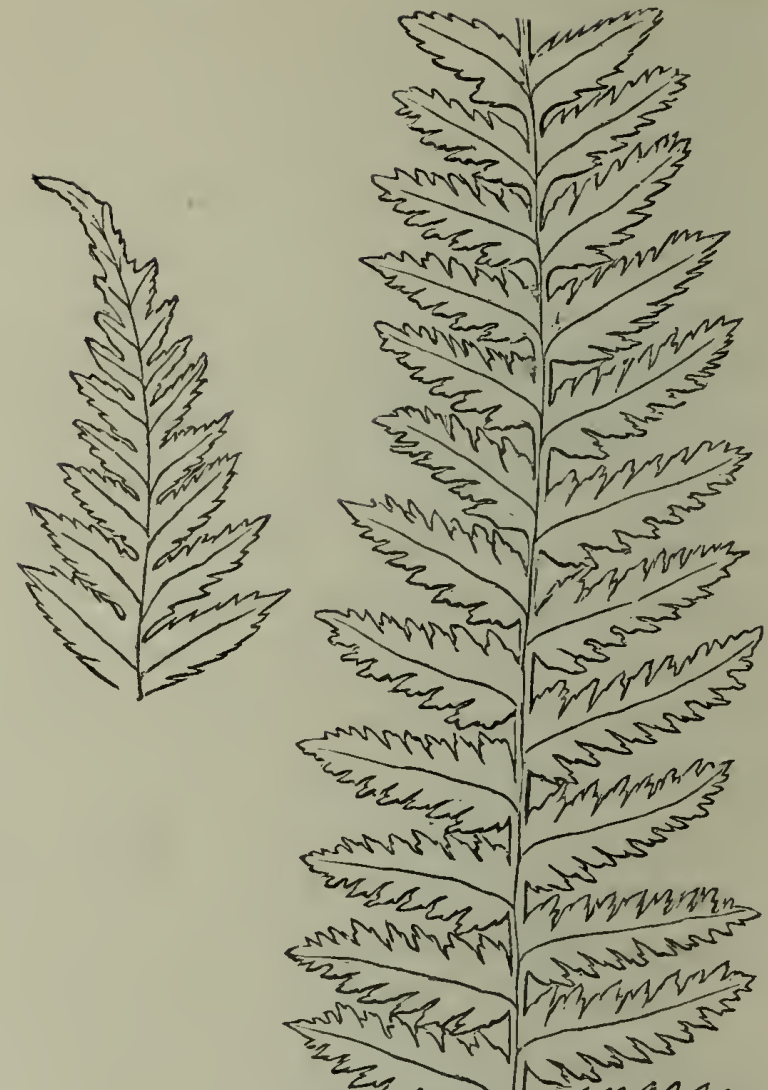

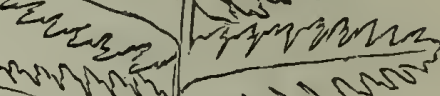

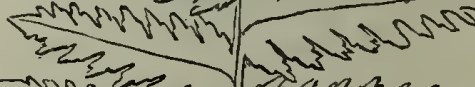
हn Wher
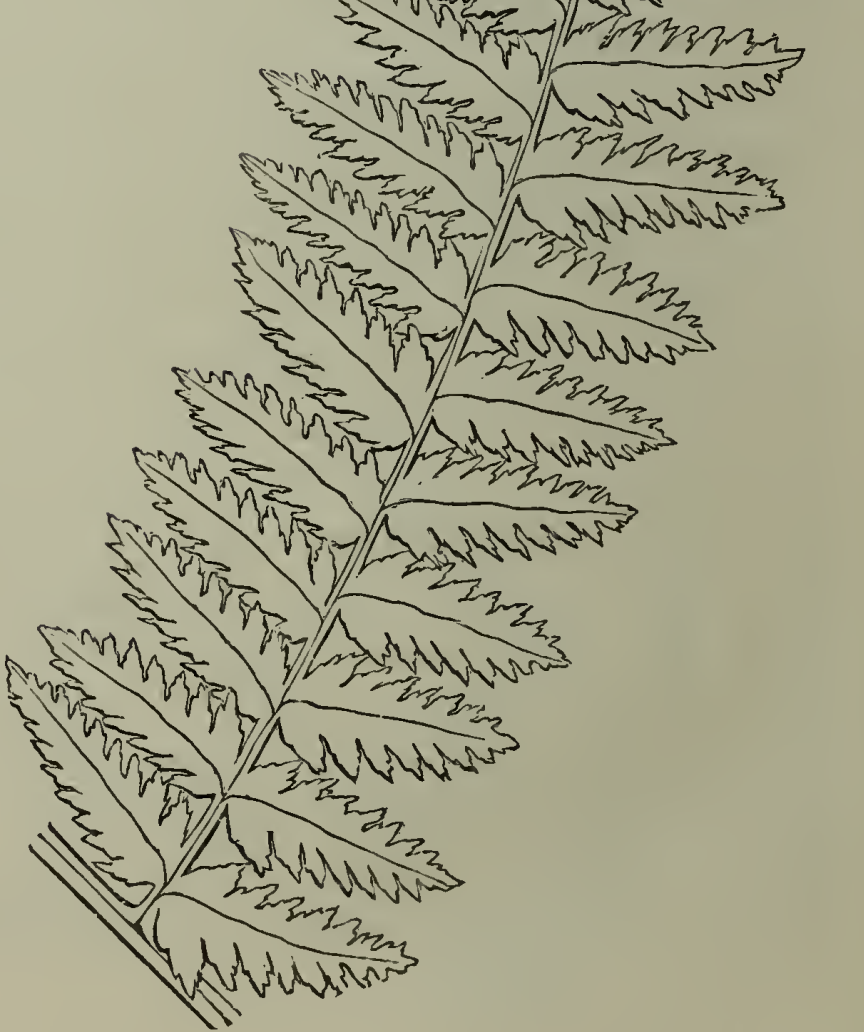
form a continuous confluent mass, as in the last species; indusium orbicular, reniform, attached to the vein by a slender pedicel, a yellowish brown colour, the margin somewhat jagged. Thece small, globose, a pale yellowish brown colour.

Habitat.-Wood, Cathcart hills, near Glasgow; and near Cockermouth.-Miss Browne.

Perennial ; in perfection in August.

Specimens of this very beautiful and magnificent Fern we collected on the Cathcart hills in 1833, where it was growing in great profusion. Its babit is that of L. Filix mas, but it appears to us to have so many distinctive marks, as will be seen from the foregoing description, that we have ventured to raise it to the rank of a species, as it is in Schkuhr's Crypt. t. 45 and 51, under the name of Aspi. dium depastum and $A$. erosum; and we regard the variety mentioned by Mr. Newman, p. 201, as being found by Miss Browne, of Tallantre Hall, Cockermouth, a pinna of which is figured p. 197, $b$, as belonging to the same species.

Our plate illustrative of this species is drawn one-sixth the natural size. The detached pinnules are represented the full size, showing the lobed and serrated margins. Fig. $a$, shows the position of the sori; and fig. $b$, the disposition of the lateral veins, and the position of the sori upon the superior branch. The marginal illustration page 102, is a detached pinna, drawn the size of nature from which a more correct idea will be formed of the size and beauty of the plant.

5. L. Filix mas, (Fig. 1609.) Male Fern. Frond oblong lanceolate, bi-pinnate; pinnæ linear lanceolate, pinnate; pinnules oblong, ob. tuse, serrated, with obtuse teeth, smooth, mostly united one to the other at the base; lateral veins forked or tufted, the anterior branches, bearing a circular cluster of thecæ, and from four to eight on a pinnule; indusium reniform, becoming circular, the margin entire or notched.

Newman's British Ferns, p. 197.-Aspidium.-English Botany, t. 1458, and (t. 1949) A. cristatum.-English Flora, vol. iv. p. 275.Hooker, British Flora, ed. 4. vol. i. p 385.

Roots brown, long, strong, tough, and wiry. Rhizoma thick, scaly, tufted, often becoming much elongated. Fronds oblong lanceolate, nearly erect, at first closely curled up in vernation, but when a little advanced, the upper part is set free, and it hangs down, forming a kind of shepherd's crook; when fully expanded, the frond is from two 
to four feet long, the stem forming about one-third its length, and more or less thickly clothed with thin brown membranous scales, as well as the rachis. Pinne linear lanceolate, opposite and alternate, mostly standing at right angles from the rachis, pinnated, a dark, smooth, shining, green above, paler and dull beneath. The pinnules are oblong, obtuse, attached to the mid-rib of the pinnule by its broad base, and one united to the other by a narrow wing; the first pair are often longer than the others, and notched and auricled at the base; the margins are entire or serrated, with obtuse teeth, the mid-vein is mostly waved, the lateral veins alternate, forked near the base, and terminating just before reaching the margin. The anterior branch bears a sorus about midway between the midrib and margin, and is rather shorter than the other. Sori mostly numerous, from one to eight on a pinnule, circular, beeoming confluent, a bright brown colour. Indusium large, reniform, becoming circular, smooth, mostly of a leaden hue, entire or waved, or notched on the margin, and remains a long time attached to the plant. Thece globose, with a beautiful beaded elastic ring. Sporules minute, numerous.

Habitat.-Woods, shady and cultivated places, banks and hedge rows; common.

Perennial; in perfection in August.

This, the common Male Fern, is one of the most abundant and generally distributed of our species; but though so common, it is not the least beautiful of our Ferns; and being so common and so gene. rally distributed, it is, as might be supposed, very variable in size and appearance, owing to the different kinds of soil and situation in which it has grown. It is not uncommon to find it in dry exposed situations in a sandy soil only a few inches long; while in positions favourable to its growth and expansion it attains the height of four feet, and even more; and this large size seems to be attained especially by the barren fronds. In Mr. Winche's Herbarium, now in the possession of the Linnæan Society, there is a specimen in fruit, having simple pinnæ, with waved but undivided margins. This remarkable variety is very rare; but it is not uncommon to find the pinnules more or less deeply toothed on the margin, and occasionally lobed, but these much developed plants are usually barren. Fig. $a$ and $b$ in the marginal illustration are drawn the natural size of the pinnæ, of two varieties of barren fronds, which, compared with the fig. $c$, which is the natural size also of an ordinary fruit-bearing plant, show the position and common number and form of the sori. Fig. $d$ is one of 


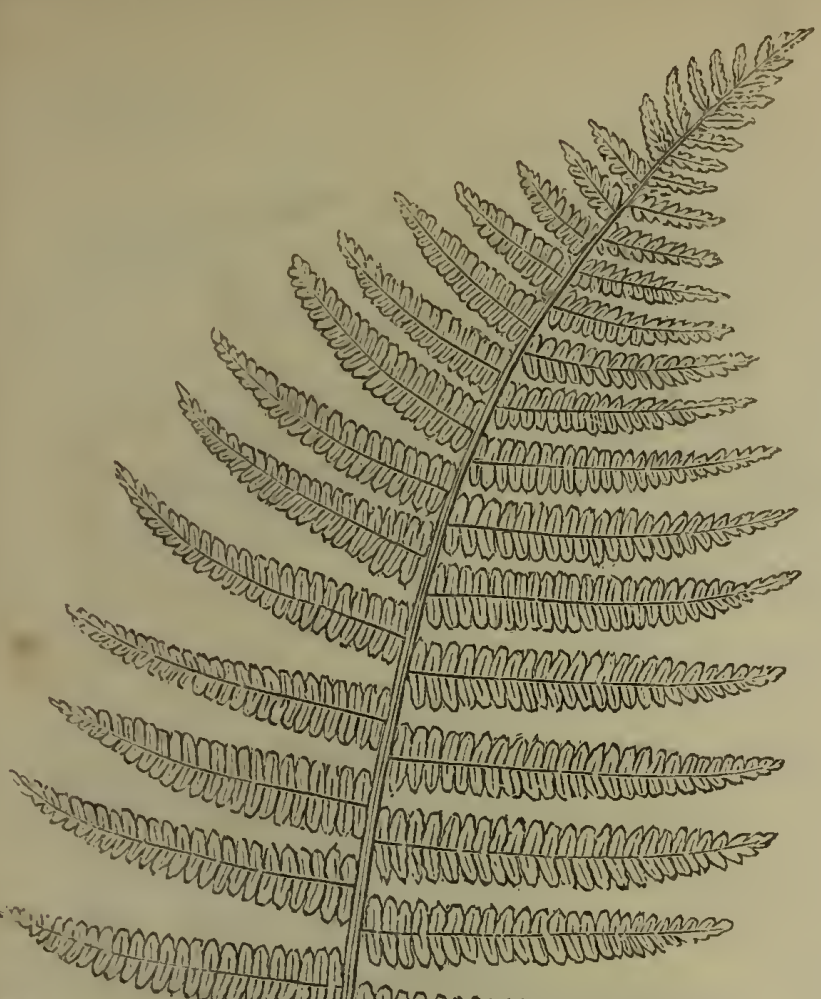
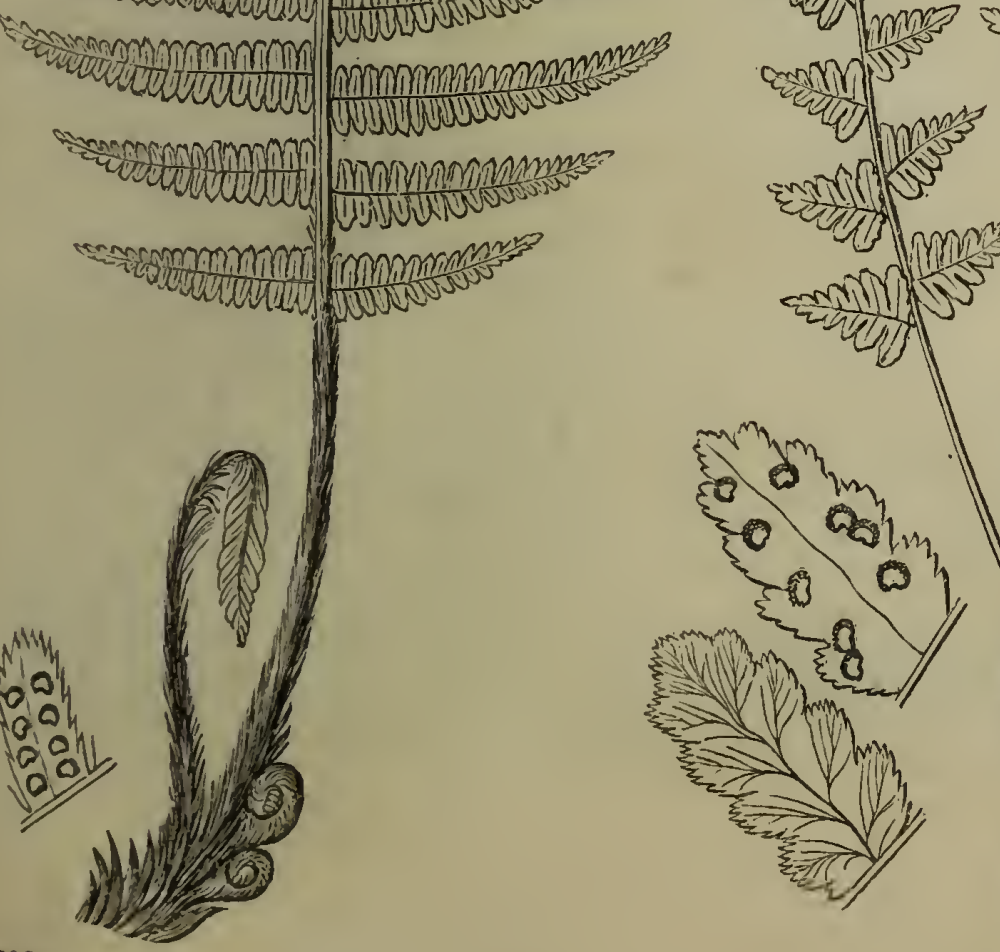

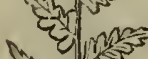
हो

, . .

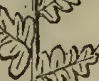<smiles>C1=[Si]=[Si]1</smiles>
con ? ine ह

shom हn in and
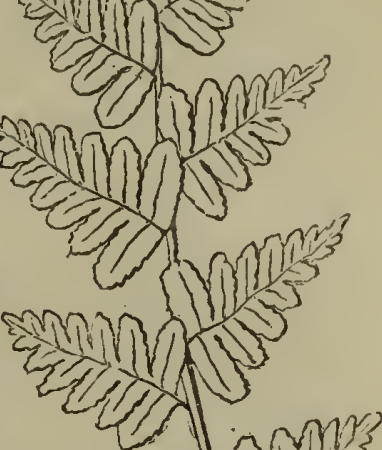

踏

mon 4 ing

animin
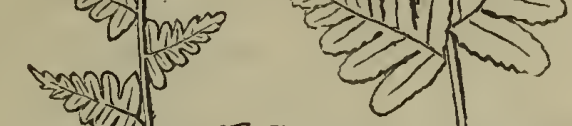

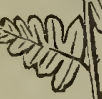

efpom
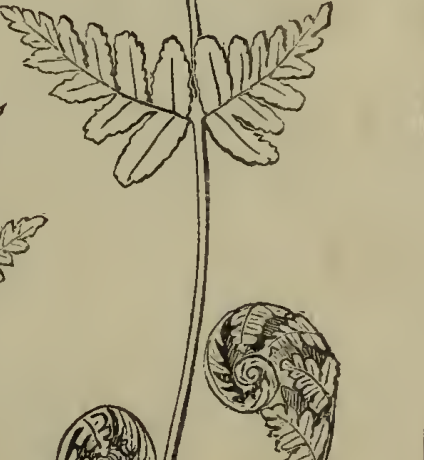
47

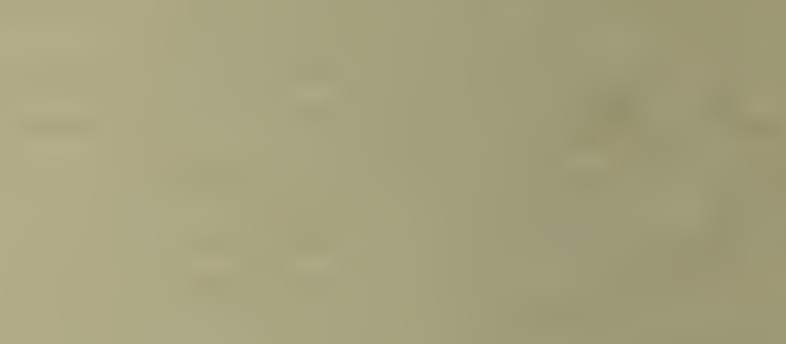

a

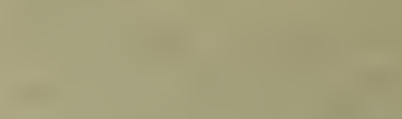

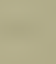
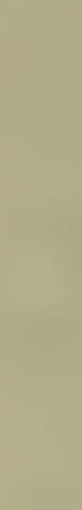

$$
\text { (n) }
$$<smiles>CCC</smiles>

.

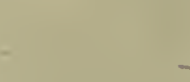

.

.

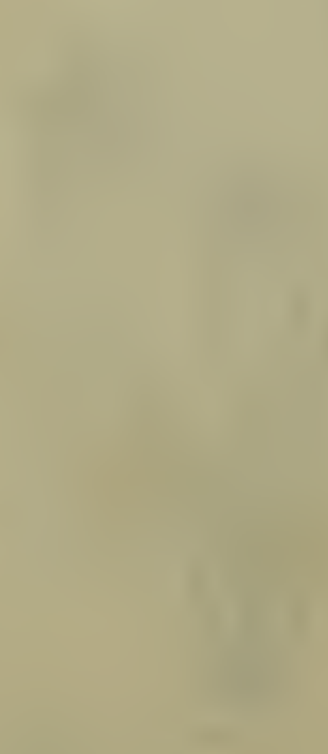

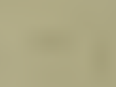

$=$
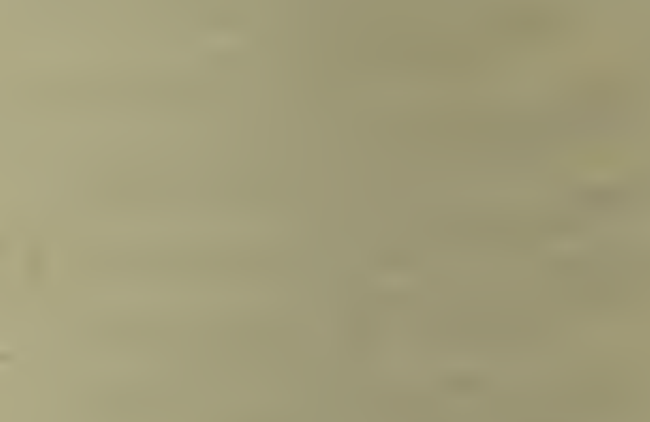

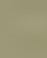
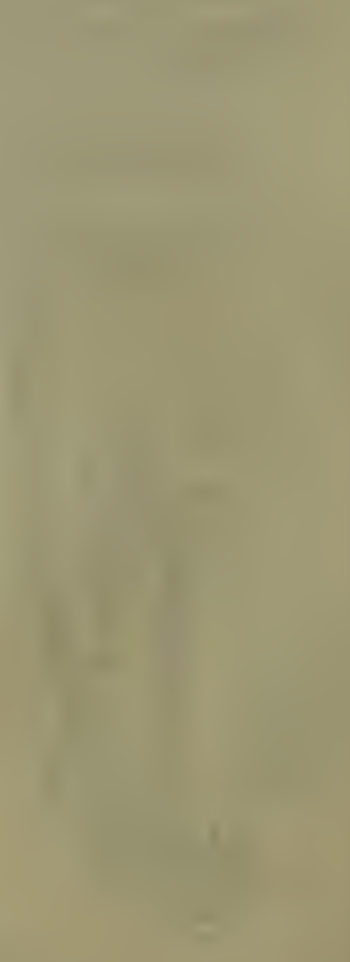

$=$ 


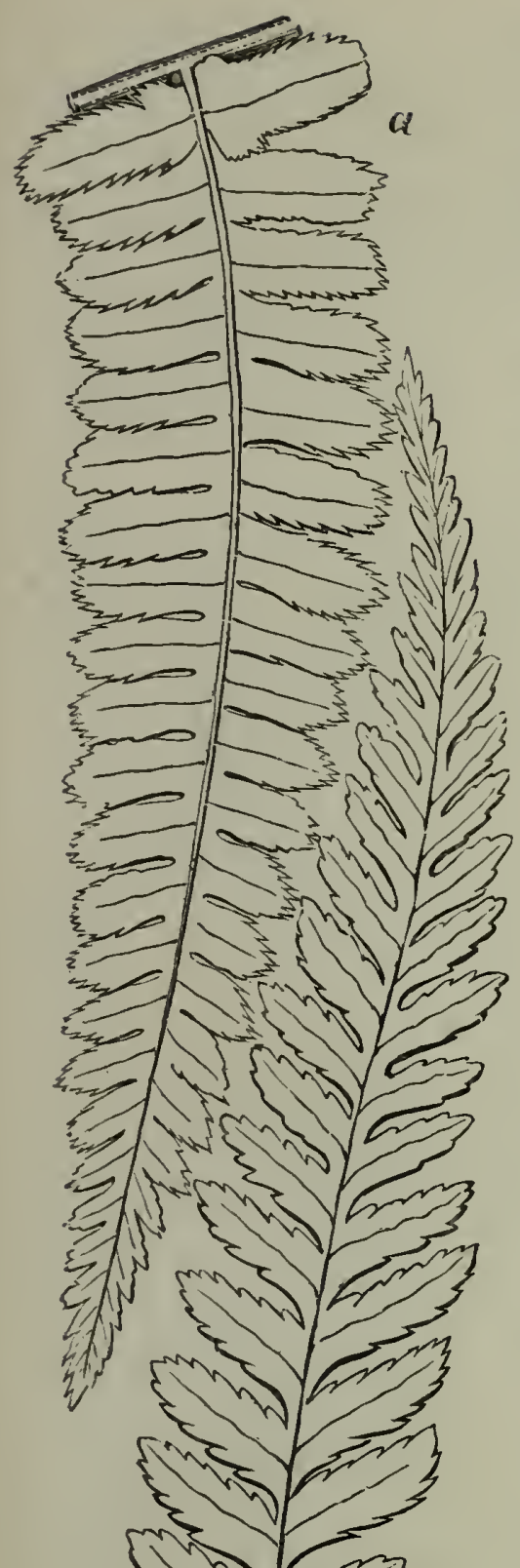

the pinnules magnified, to show the disposition of the lateral veins, and the arrangement of the sori upon the superior vein. Figs. $e$ and $f$ are two forms of the indusium, as they are usually found, detached, and magnified. The plate (fig. 1607) is a plant drawn onefourth the natural size, and shows the mode of its developement from the rhizoma. Mr. Newman mentions a plant departing from the usual form, found near Stormont House, Belfast. "The points of discrepancy," he says, "are these: frond narrow, elongate; pinnules very distant; clusters of capsules (thecæ) separate and distant: I am indebted to Mr. Moore for a specimen of this curious plant." Another form Mr. Newman mentions, which grows in the north of Fngland in company with Lastrae rigida; and of a specimen sent him from Ingleborough, by $M r$. Pinder, he says, "in this plant the great discrepancy exists in the smaller size, a foot being its extreme length, and in having its large clusters of capsules (thecæ) confined to the base of the pinnules, where they form a crowded confluent line, which completely covers the

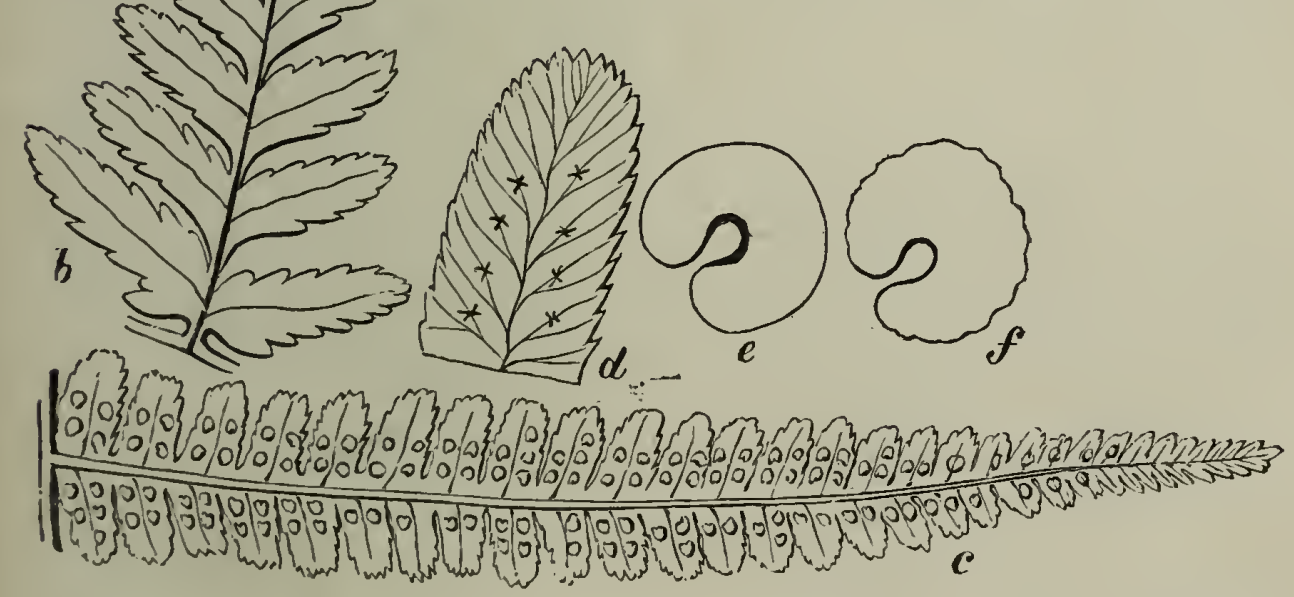


mid-rib of the pinnæ." Mr. Newman adds, that-_" From a very careful comparison of this plant with the description of Decandolle's Polystichum abbreviatum, (Flor. Franc. 2,560,) we are induced to pronounce them identical, yet scarcely inclined to consider the discrepancy from the usual form of Filix mas sufficient for the establishment of a species." Besides these there are many other forms and peculiarities of the plant; as having the indusiums lead colour, or brown, very small or large, numerous and crowded, or few and distant.

The name Filix mas, Male Fern, has been applied to this plant from a very early period; and it was formerly much extolled as a remedy of great value for the expelling of worms from the intestines; it is still retained amongst the list of the Materia Medica, and various curious formulæ are found amongst the old authors for its administration. The rhizoma dried and powdered is the part of the plant used. Madame Naufer obtained some years since great celebrity by employing it as a specific in the cure of tapeworm, and of such importance was the secret considered by some of the principal physicians at Paris, who were deputed to make trial of its efficacy, that the secret was purchased by the French King, and afterwards published by his orders. Two or three drachms of the powder of the dried rhizomas were given fasting, and after the lapse of two hours a cathartic composed of calomel and scammony, in proportions according to the age and strength of the patient: if the dose did not operate fin due time, a dose of Cathartic salts was directed to be given; and if the worm was not expelled in a few hours, the process was repeated at proper intervals. It may be fairly doubted in this process which was the cause of expelling the worm, the powdered fern or the calomel and scammony; the latter is most generaily believed to have been the active means, and within the last few years a treatment similar to the above has been revived by Dr. A. T. Waurruch, of Vienna, and with success; but in his plan great care is taken in preparing the patient before the administration of the fern, by means of repeated doses of aperient medicine and a spare semifluid diet, so as to remove all obstructions to the full action of the fern; but even with this precaution the severe means used snme. times produce inflammatory action in the bowels.

The whole plant abounds with astringent matter, so much so that it has been used for the purpose of tanning leather. The dried plant, when burned, furnishes, as the Brackes do, a considerable proportion of alkaline salt, which is used in the process of cleansing 
linen, \&c., and in the manufactory of glass. In Norway, the fronds are used as fodder for oxen, horses, sheep, and goats ; and there, as well as in the mountain districts of Italy and Switzerland, it is col. lected on the hills and mountains, and dried and kept in store as winter provender for cattle and litter for horses; and from its abound. ing in saline matter and the thin texture of its fronds, it quickly forms an excellent manure.

6. L. crista'ta, Presl. (Fig. 1610.) Crested Fern, or Ehrhart's Fern. Fronds erect, linear lanceolate, pinnate; pinnæ distant, nearly triangular, or ovate lanceolate, deeply pinnatifid; pinnules oblong, ovate, obtuse, serrated; lateral veins much branched; sori midway betwe een the margin and rib.

Newman's British Ferns, p. 203.-Aspidium.-English Botany, t. 2125.-Hooker, British Flora, ed.4. vol. i. p. 384.-English Flora, vol. iv. p. $2 \pi 6$.

Roots fibrous, much branched and matted together. Rhizoma large, stout, elongated, often branched, enveloped with the decurved bases of old fronds. Fronds several, erect, of a linear lanceolate or elongate lanceolate form, pinnate, of a pale yellowish green colour, and from one to two feet high. The stem forming about one-third its length, and naked, with the exception of a few short broad obtuse pale uniform brown coloured membranous scales. The frond is curled up in vernation, the pinnæ laying folded one over the other. Pinna opposite or alternate, mostly distant from each other, of a triangular form, short, quite smooth, the pinnules oblong, ovate, obtuse, lobed in a pinnatifid manner, and each lobe from two to six toothed, the teeth with a mucronate point, the mid-rib waved, the lateral veins alternately branched, sending a branch to each tooth, the anterior branch generally only bears a sorus about midway between the mid-rib and margin, but in luxuriant plants other branches bear sori also, so that they become confluent. Sori nearly circular, confined to the upper part of the frond. Indusium flat, reniform, with the margin mostly sinuated, attached by a lateral stalk, as the thecæ increase in size all around it, the form becomes more circular, and it remains attached even after the sporules are discharged. Thece small, numerous, attached at the base by a slender pedicel. Sporules minute, reniform, roughish.

Habitat.-Boggy heaths; very rare. Edgefield and Bawsey-heath, near Lynn, and near Dersingham, Norfolk; Oxton bogs, and Bulwell marshes, Nottinghamshire; bogs at Wistleton, Suffolk; bog near Madeley, Staffordshire; and it is said to be found both in Ireland and Scotland 
Perennial; in perfection in August.

This rare species is remarkable for the long and branched rhizomas which it produces. It is more frequent on the Continent than with us, and also in America.

The plate (fig. 1610) illustrative of this species is drawn one-fifth of the natural size, and shows the mode of its vernation and the circular manner in which the fronds arise around the crown of the rhizoma. The detached pinuules show the manner in which the veins are distributed, and the position of the sori when they are but few in number.

7. L. spino'sa, Newman. (Fig. 1611.) Withering's Fern. Stem about the length of the frond, green, clothed with roundish oblong short pointed scales, of an uniform pale brown colour; frond nearly erect, flat, elongate, lanceolate, smooth; pinnæ pinnate, the lower four to eight pair of equal length; pinnules pinnatifid, or pinnate, the two first lower ones of nearly equal length, lanceolate, and twice as long as the opposite ones, the rest more equal and oblong, the lobes (secondary pinnules) united by a narrow wing, except the first basal ones, which are also cut; all are deeply serrated with spinose pointed teeth, curved towards the apex; mid-vein waved, alternately branched, and terminating before reaching the margin, the anterior branch bearing a sorus beneath the cleft of the lobes; indusium with an entire or waved margin, without glands; the lower pinnæ without fruit.

Newman's British Ferns, p. 209.-L. spinulosa, var. (Presl.)Babington's Manual, Ed. 2.

B. Crispa. (Fig. e.) Very rigid, the margin of the lobes of the pinnules closely rolled back, and partly concealing the sori.

Root numerous, black, branched, matted together. Rhizoma large, thick, branched and tufted. Fronds erect, becoming drooping, from two to four feet high, flat, of an elongate lanceolate figure, quite smooth. Stem green, about as long as the frond, rather slender, channeled above, rounded at the back, clothed at the base with crowded scales, more scattered above, and but few on the rachis. The scales are roundish oblong, with a short point, of a pale brown uniform colour, very thin, membranous. The pinnce are pinnate, lanceolate, opposite and alternate, the first pair obliquely lanceolate, from the lower pinnules being double the length of the opposite ones, those of the second pair more equal, and cease to be different in the fifth or sixth. The lower three or four pair of pinnæ are of about the same length. Sometimes when the frond is large, the lower eight 






pairs are the same length, and after that they gradually diminish to the point. The pinnules are lanceolate or oblong lanceolate, pinnated, alternate. The two lower ones of the first pair of pinnæ are much larger than any of the others, and twice as long as the opposite ones. The rest of the pinnules on the same side are also longer than their opposite ones, but not so greatly disproportionate as the two first. This discrepancy in the size of the pinnules is less marked on the second pinnæ, and gradually diminishes to the fifth and sixth pair, but none of them have the two first pinnules so mueh larger than the others, except the first pair. The lobes (or secondary pinnules) ovate oblong, obtuse, serrated, with sharp spinous teeth, curved towards the apex, the lower basal ones often deeply lobed and toothed, and the upper smaller ones often only toothed at the obtuse end; each pinnule, though distant one from the other, are connected by a narrow wing on each side of the mid-rib, and the lobes are also connected together in the same way. Lateral veins alternately branched, each branch terminating before reaching the margin, and each anterior branch bearing a sorus immediately beneath the cleft of the lobes, so that they form a regular double series on each side of the mid-rib of the pinnules, and frequently also on each side of the larger basal lobes. Indusium flat, reniform, smooth, with an entire or slightly waved or notched margin. Theca numerous, globose. The sori are for the most part confined to the upper part of the frond, rarely or but few upon the lower pinnæ.

Habitat.-Moist woods and marshy places, not unfrequent in England; less cornmon in Wales, and not recorded, as found in Scotland or Ireland; $\beta$. near Sheffield, Yorkshire.

Perennial; in perfection in August.

We have no hesitation in following Newman in separating this as a distinct species from $L$. multiflora: the difference between them he has clearly pointed out, and we have endeavoured to embody his observations of the distinguishing characters in the above description. It varies greatly in size, and in the more or less elongated form of the frond. Our illustration (fig. 1611) is drawn one-sixth the natural size of a moderate sized plant, and below it is drawn a separated scale to show its form. The marginal illustration, (fig. $a$ page 110 ,) is a pinna drawn the natural size, to show more clearly its form and the distribution of the sori upon the pinnules and lobes Fig. $b$ is one of the lower secondary pinnules magnified to show the distribution of the laterul veins, and in fig. $c$, which is one of the upper lobes, is shewn the position of the sorus beneath the cleft. Fig. $d$ is an involucre 


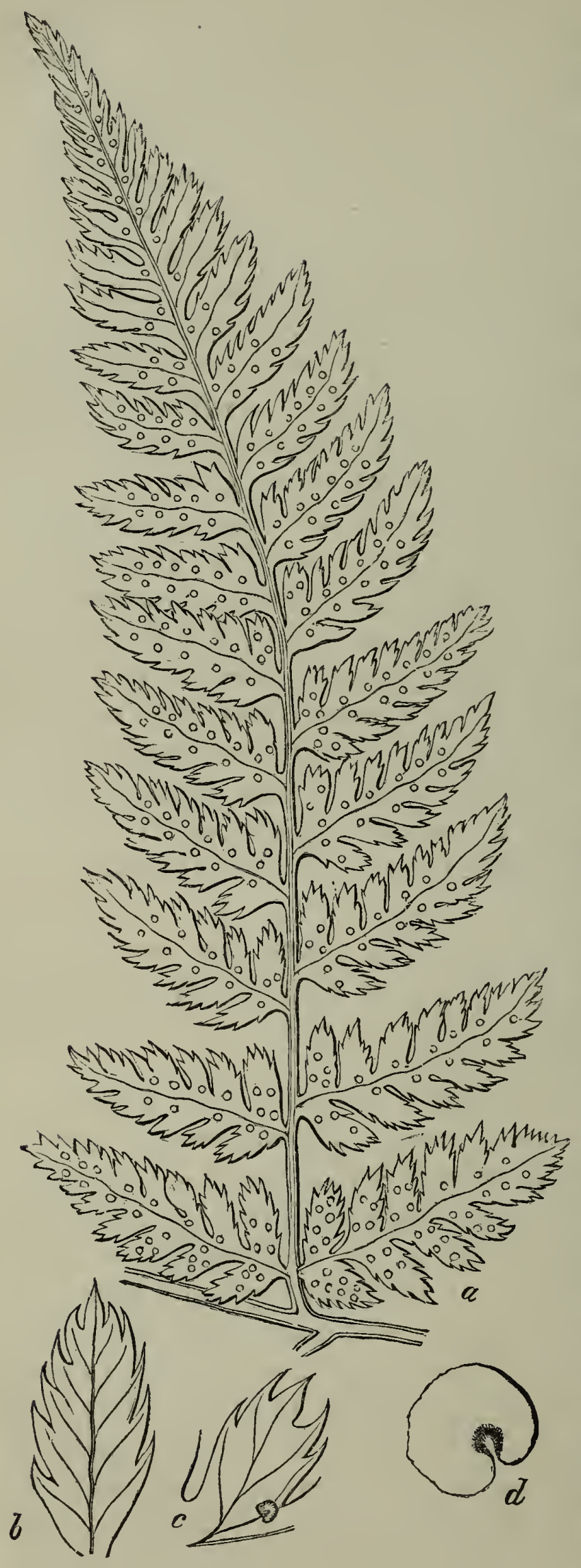

detached and magni fied, to show its form and the even margin. In the accompanying sketch is represented (fig. e) page 111, two pinnæ attached to the rachis of the natural size of the remarkable variety $\beta$. crispa; and fig. $f$, page 111 , is one of the pinnules separated and drawn larger than natural, to more clearly show its form, and the distribution of its lateral veins. The structure of the plant is extremely rigid, and its margins so rigidly curled back as to be retained when un. curled with great difficulty. The sori are much larger than in the usual form of the plant, and much darker, almost black.

8. L. maculata, Deakin. (Fig. 1612) Spotted Crested Fern. Stem about as long as the frond, thickened at the base, and thickly clothed with long pointed lanceolate scales of an uniform brown colour; frond, oblong lanseolate, curved, a 
sin

$\theta h^{n}$

대의

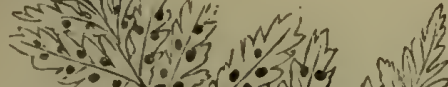

m- $-7 \div 3 \%$ औ

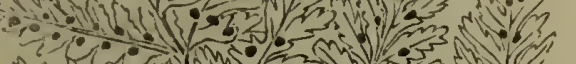

-

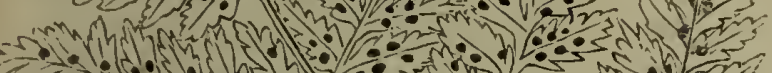

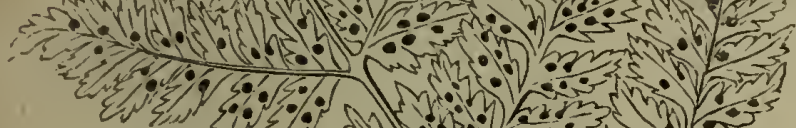

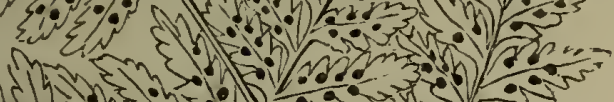

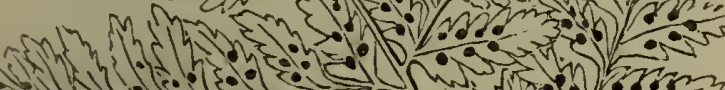

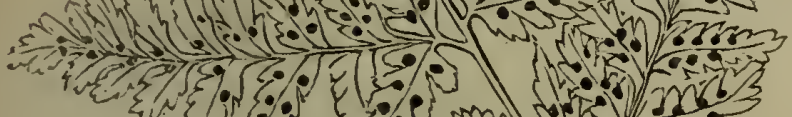

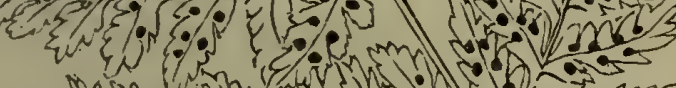

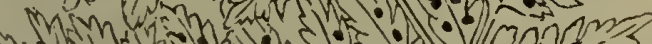

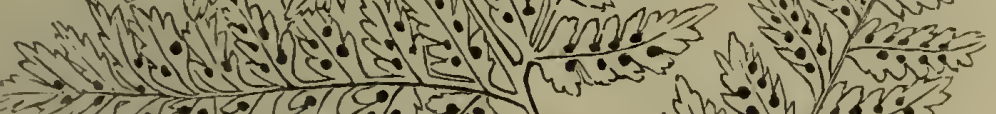

=

हn

n

है

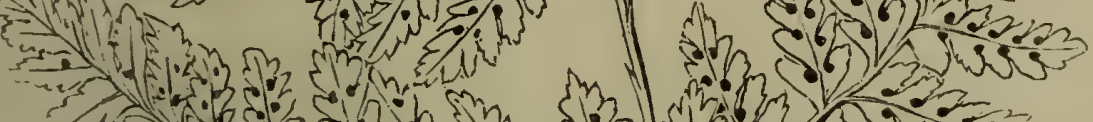

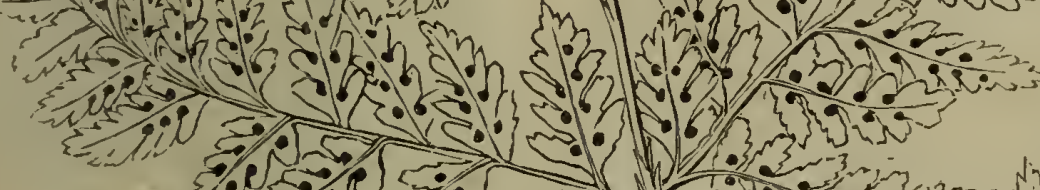

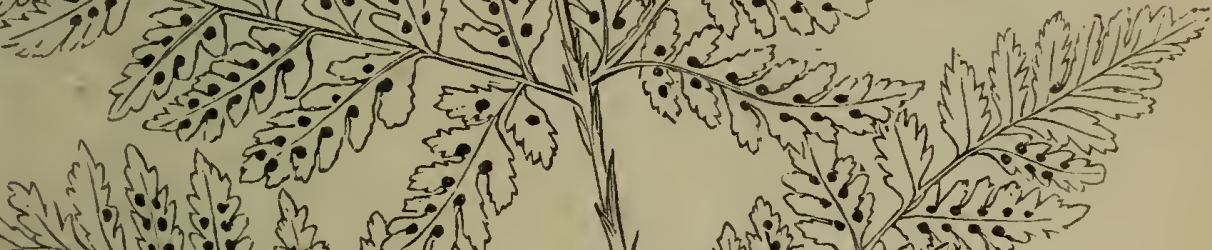

F,

=m

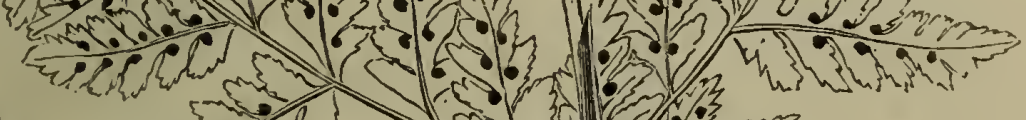

Nin

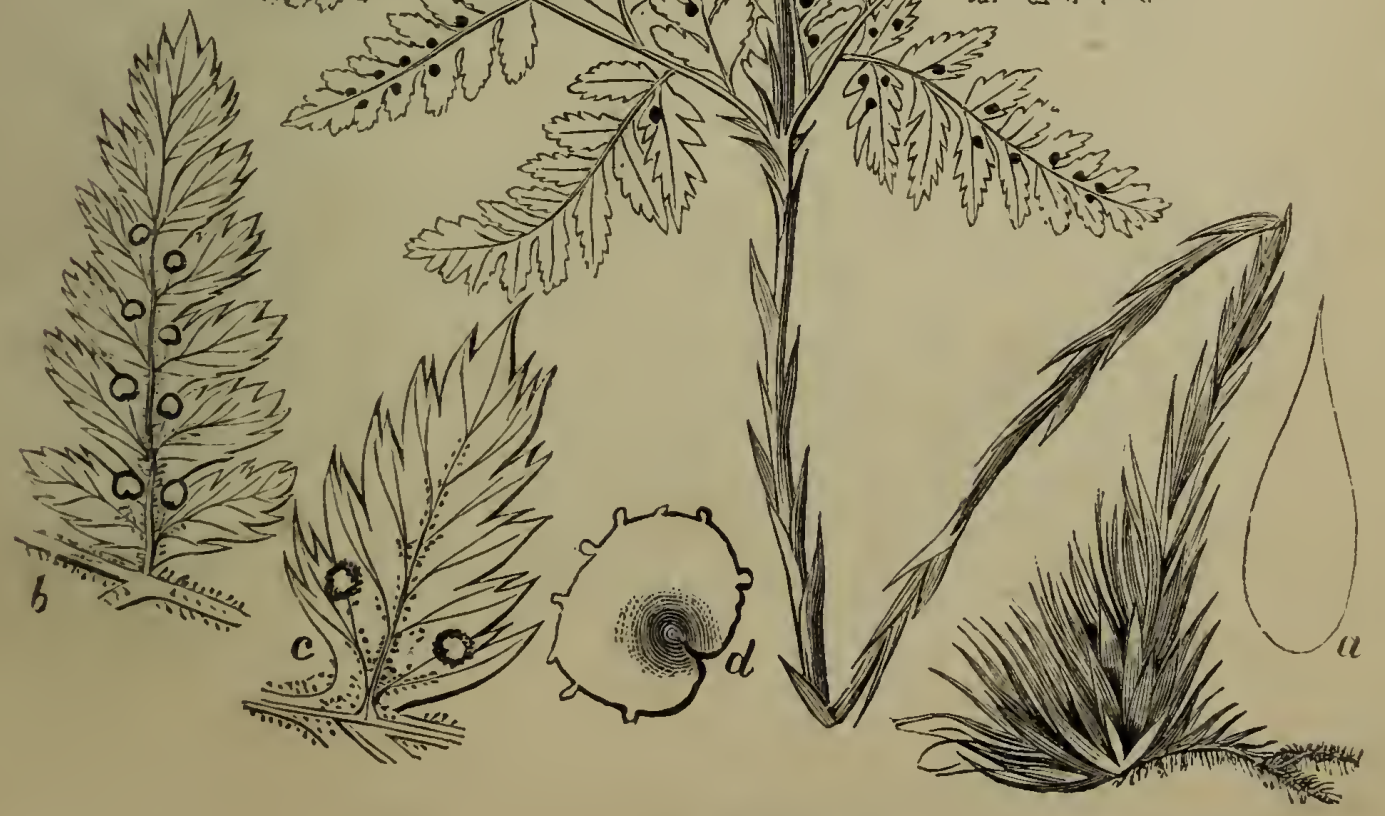

1612

Lastraa maculata. 



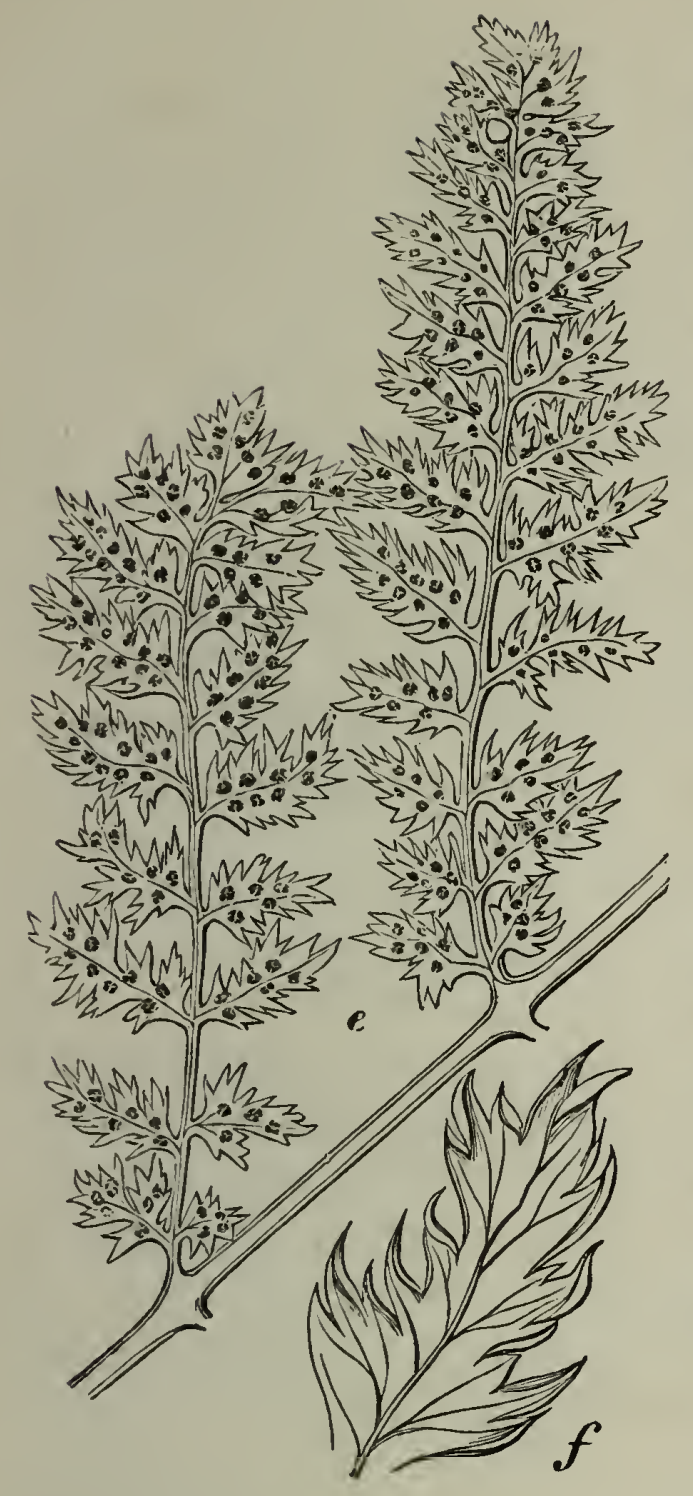

dark green, and smooth above becoming spotted, pale, and scattered over with stalked glands on the under side; pinnæ pinnate, the lower four to six pairs of nearly equal length, elongate, deltoid, the rest lanceolate; pinnules lanceolate, the first lower ones larger than the rest, all distinctly stalked except towards the points; the lobes (secondary pinnules) oblong lanceolate, the lower ones stalked and deeply cut in a pinnatified manner, and serrated with acute spinous teeth, mid-rib waved, lateral veins, alternately branched, terminating in the spine, each anterior branch bearing a circular sorus immediately below the angle of the cleft; indusium, an irregular reniform figure, with an uneven margin, mostly fringed with stalked glands.

Roots fibrous, branched villous, dark brown. Rhizoma tufted, scaly. Stem thickened at the base and thickly clothed with lanceolate scales of a reddish brown uniform colour, thin and membranous, the lower ones are narrow, with a long tapering point, those in the upper part of the stem are less crowded, often distant, larger, and more oblong in figure but without the dark brown broad band in the middle, as in the following species; the upper part of the stem is green, slender, channeled on the upper side, rounded at the back, and is as long, often longer than the rest of the frond, which is of an oblong lanceolate figure, the three to six lower pinnæ of uniform length, the rest gradually diminishing to the point, a dark green colour on the upper surface and quite smooth, becoming scattered over with dark purplish-brown blotches of very irregular shape and size, which 
equally stain the under surface, which is of a pale dull green, and scattered over with sessile and stalked glands, most numerous along the ribs at their base; the pinnce are opposite and alternate lanceolate, the lower ones unequally lanceolate from the pinnules being longer on the lower side than the upper, the first lower basal pinnule being larger than the rest: the disproportion is less on the other pinnules, and ceases to be observable in the fourth or sixth; the pinnules are oblong lanceolate, pinnated, distinctly stalked, except toward the point, the lobes, (secondary pinnules,) oblong, ovate, acute, or obtusely pointed, the lower one of the large pinnules on a short footstalk, the rest attached by their broad base, and united to each other by a narrow wing; they are lobed and toothed, the teeth terminating in a rather long bristle point, which becomes hooked or bent and at length falls away, leaving the tooth with a blunt point; the mid-rib of the pinnules and lobes and the lateral veins are prominent, often a purplish colour the lateral veins are simple or branched, sending a branch to each tooth, which terminates in the bristle of the tooth, the upper branch of each division bears a sorus just beneath the cleft of the lobe in a regular order as seen in the plate (fig. 1612); all the pinnæ bear sori, but the lower ones are often without and not so regularly distributed as in the upper ones; the indusium is flat, almost circular, with a notch on one side, where it is attached by its short cord to the lateral vein, the margin is more or less notched and serrated with sessile or stalked semi-transparent glands, which seem to fall off as the plants advance to maturity; the theca are small globose, a pale yellowish brown protuding beyond the indusium but never becoming confluent.

Habitat.-The crevices of rocks on the top of Goatfell Mountain, Isle of Arran, 1832.

Perennial ; in perfection in August.

It is with much hesitation that we give this plant the rank of a species, still we know not to which species to refer it - the preceeding or following; its characters pertaining to both, and still different to either of them: it is at once obviously different from $L$. spinosa by the staiked glands upon the under side and margin of the indusium, but approaches it in the biserial arrangement of its sori, and these placed each immediately under the cleft of the lobes, and the scales of the stem, though of the form of $L$. multiflora, still they are of uniform colour like L. spinosa. From L. multiflora it differs in its stem being longer and its scales being of an uniform colour, as above stated; its secondary lobes are more deeply cut and serrated, and the 

lateral veins terminate in the point, and the sori are immediately under the cleft of the lobe, not in its middle as in L. multiflora, the texture of its frond is thinner and more transparent, and becomes stained with dark purple brown blotches.

Our illustration of this plant (fig. 1612) is drawn the natural size of a moderate sized frond, and shows the disposition of the sori on its under side; (fig. $a$ ) is a scale drawn larger than the natural size; (fig. $b$ ) is one of the upper pinnules magnified to show its deep cut lobes and teeth, and the distribution of the lateral veins and sori; (fig. $c$ ) is one of the secondary pinnules, of a lower pinnule magnified still more; both show the numerous glands on the under side: and (fig. $d$ ) is an indusium magnified, separated, and exhibiting its form and glandular fringed margin.

The largest frond which we have found is not more than half as large again as the one represented; many are much smaller; and in all, there is a tendency in the pinnules to curl on the under side, especially towards the top of the frond.

9. L. multiflora, Newman. (Fig. 1613.) Roth's Fern, or many Fruited Fern. Stem about one-third the length of the frond, green, rery stout at the base, and thickly clothed with long pointed lanceolate scales, dark brown in the middle, pale in the margins, frond oblong, lanceolate, curved, seattered over on the under side with stalked glands, pinnæe pinnate, the lower pair shorter than the second and nearly triangular, the fourth and fifth linear longer than the rest; pinnules lanceolate, the lower ones with distinctly stalked oblong obtuse, cut, and serrated lobes (secondary pinnules), the rest elliptic, ovate, obtuse, curved downwards, all with acute spinous teeth, mid-rib waved, lateral veins alternately branched, and terminating before reaching the margin, the first inner branch bearing a circular sorus near the base of each lateral lobe ; indusium of an irregular reniform figure, with a jagged margin fringed with sessile or stalked glands.

Newman's British Ferns, p. 215. Aspidium spinulosum, and dumetorum, Smith, English Flora, v. 4. p. 279, 281. Hooker, British Flora, ed. 4. v. 1. p. 386.

B. dilatata. (Fig. a, page 116.) Frond drooping, dark green, broadly triangular, pinnules oblong, their lobes (secondary pinnules) ovate oblong, often convex.

Aspidium dilatatum. English Botany, t. 1461. English Flora, vol. 5. p. 280. A. spinulosum, Willd. Hooker, British Flora, ed. 4. vol. 1. p. 386 . 
$\gamma$. Nana, Newman. Frond small, rigid, convex in every part, dark green inclining to brown, sori large, distant, indusium small, shapeless, without glands on the margin.

Newman's British Ferns p. 222.

8. Collina, Newman. Frond elongate lanceolate, stem half its length, pinnæ pinnate, the lower deltoid, the upper lanceolate, pinnules ovate, obtuse serrated with obtuse teeth, sori large becoming confluent, indusium with stalked glands on the margin.

Newman's British Ferns, p. 223.

Roots numerous, long, black, tough, and wiry. Rhizoma large, tufted, very scaly. Frond arched or pendulous, from two to five feet high; and in vernation "the main stem of the frond, instead of being regularly circinate or composed of diminishing rings, like those of an Ionic volute, is doubled near the insertion of the second pair of pinnæ and turns back, forming a kind of loop." Newman. The stem is very thick at the base, and thickly covered over with long pointed lanceolate scales, pale on the margin, dark brown along the middle; it is almost as long as the frond and of a green colour, channelled on the upper side, rounded at the back. The pinne are opposite and alternate lanceolate, the lower pair shorter than the others, almost triangular from the pinnules on the lower side, towards the base, being twice as long as those on the upper, the second pair is longer and more distant from the lower pinnæ than those above, its lower pinnules are also less disproportionate, and this inequality between the upper and lower pinnules gradually diminishes, and the pinnæ are nearer to each other to the apex. The pinnules are oblong, lanceolate alternate, all having those on the under side longer than those on the upper, the first basal one on the lower pinnæ is much larger than any of the others, and the lobes (secondary pinnules) on the under side are larger and more cut than those on the upper, and have a short footstalk, this disproportion is less observable on the other pinnules, except the basal one, which is for the most part stalked, the rest are attached to the mid-rib of the pinnule by a broad base, though many are notched on the upper side, the rest are connected by a narrow ring one to the other; the lobes (secondary pinnules) are ovate, obtuse, serrated at the end, and often on the sides, the teeth acute, with a sharp point, often long and bristly. The mid-vein is waved, sending alternately a lateral vein to each tooth, and terminating before reaching the apex; when the lobes are notched, and these lateral lobes are serrated, they have a mid-vein and lateral branches, also one to each tooth, and most 
of these lateral veins bear a sorus near the base, and all the pinnæ are fruit-bearing, so that this is one of its more prominent distinguishing characters from both the former species. The indusium is irregular in shape, more or less reniform, almost circular, more or less uneven on the margin, and more or less fringed with stalked glandular bodies. The Theca ure numerous, small, pale brown, soon pushing away the indusium, which curls up into a shapeless form, and remains attached some time, or falls away. The upper surface of the frond is smooth, a dark green, paler, and dull, not bright green beneath, and more or less profusely scattered orer with stalked glands, especially about the ribs and the base of the pinnules and their lobes.

Habitat.-Moist woods, banks of hedges, and shady places, especially in a rich loamy soil; $\beta$. in similar situations; $\gamma$. boggy and billy districts of Ireland and Scotland, less frequent in Wales; 8. hills, Westmoreland, Yorkshire, and Lancashire.-Miss Beever and Rev. G. Pinder.

Perennial ; in perfection in August.

The characters by which this species are distinguished will be more clearly seen by our illustrations; the plate (fig. 1613) is drawn one-fifth the natural size, and the scale separated at the base is represented the natural size of one from the middle of the stem, and shaded as they are found

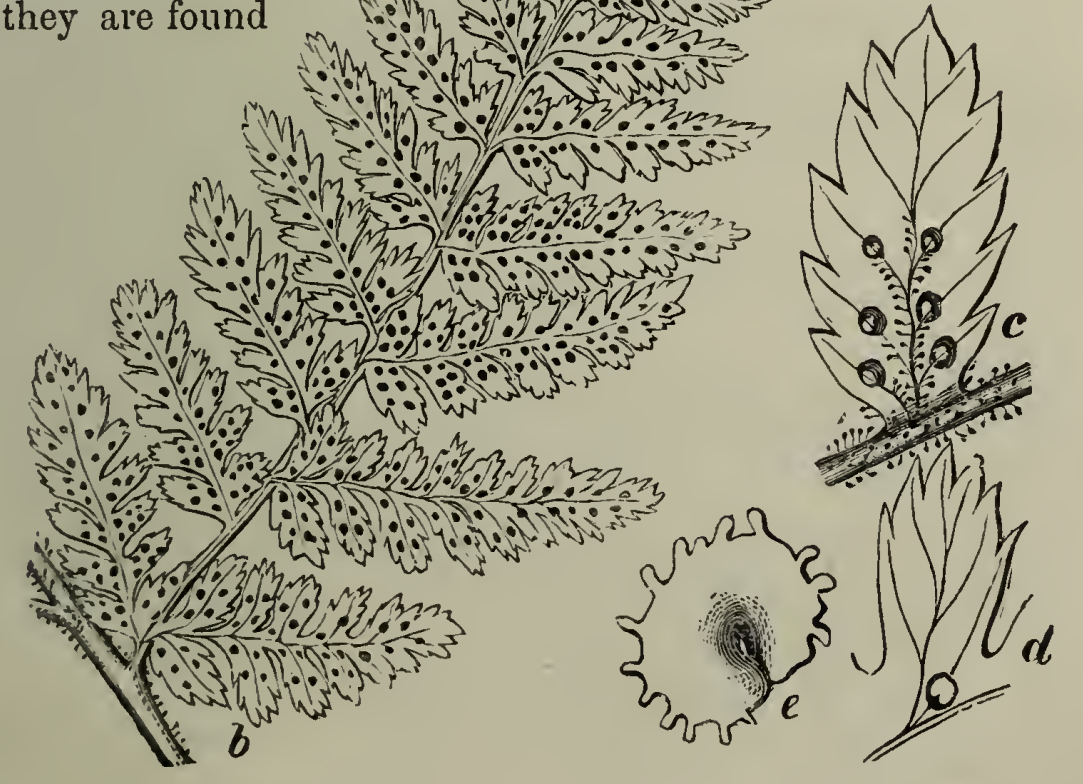


in the middle, and pale and thin on the murgins. The marginal illustration (fig. $b$, page 115 ) is a pinnule, from the upper part of the frond, drawn the natural size, and shows the number and distribution of the sori; (fig. c) is one of the basal lateral lobes, separated and drawn larger than natural to show the form of the teeth, the arrangement of the veins, the situation of the sori, and the numerous glands; (fig. $d$ ) is a portion of the upper part of the pinnule showing the position of the sorus upon the lateral vein and base of the lobe, and not at the angle of the cleft, as in the two former species; (fig. $e$ ) is one of the indusiums separated and magnified to show its form and the stalked glands on its margin.

The variety $L$. dilatata has a frond of a triangular form, dark green on the upper side, pale and glandular beneath, the pinnæ lanceolate, the lower one of a much more deltoid form than any of the others, from the lower pinnules being larger than those of any of the others; the sori are larger and arranged in a more regular biseral manner than in the normal form, as will be seen in the pinnæ represented in the marginal illustration (fig. $a$ ), drawn the

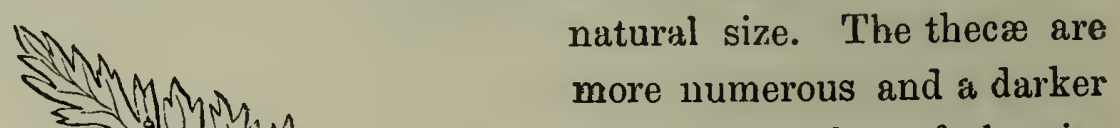
brown, the lobes of the pin-

nules are broader, with

larger teeth and more obtuse at the apex: frequently, however, growing with this triangular form of frond, are found others of a much more elongated lanceolate figure, approaching the normal form.

The variety $L$. nana is a much smaller plant, more rigid, with large are found and distant sori, with the indusium without glands; and Mir. New man says, "Its characters did not appear changed by cultivation for two years, at Leominster, yet I feel by no means satisfied that it is more than a starved state of the common plant, and if so, should not be admitted as a variety." 


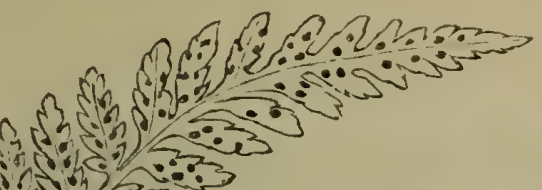
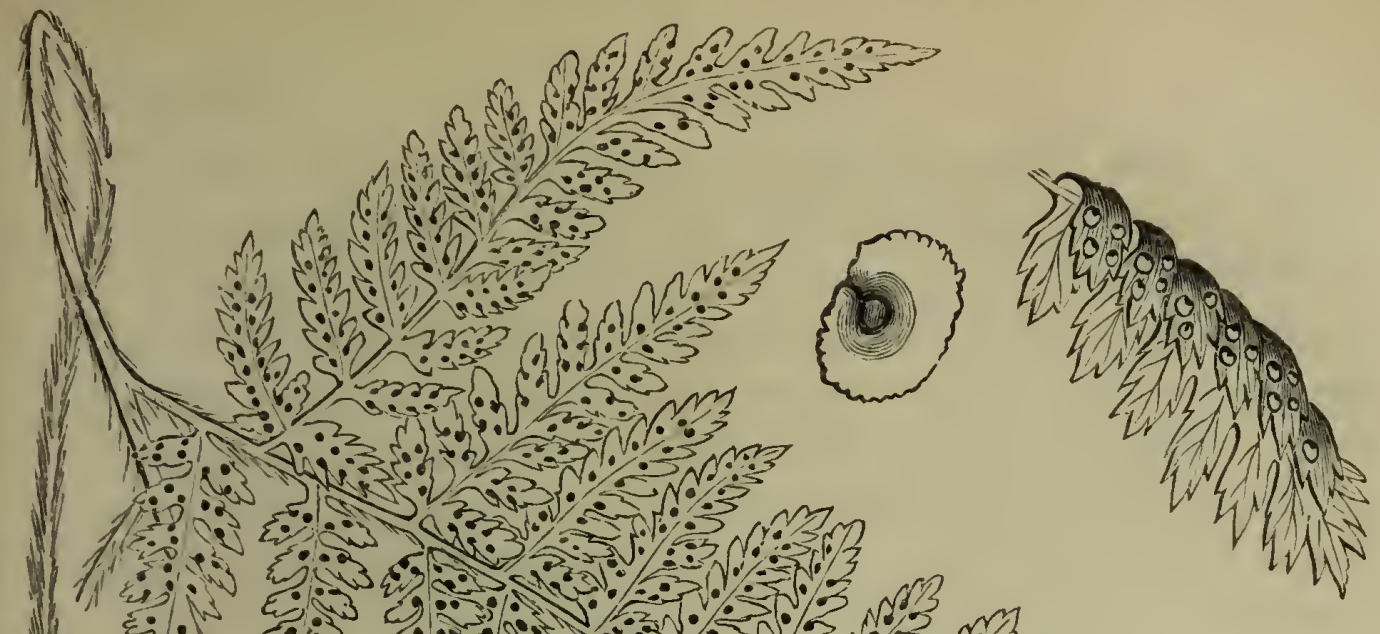

है. W E

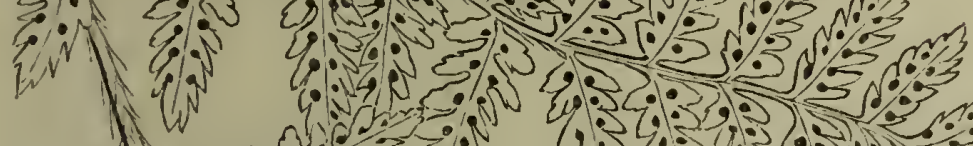

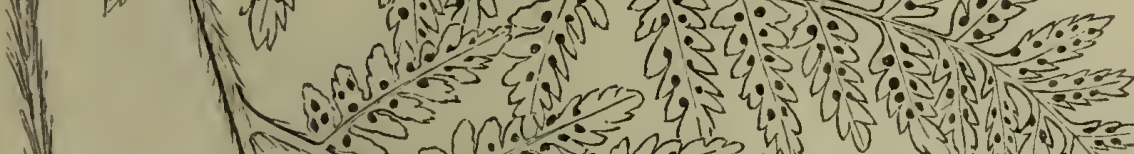

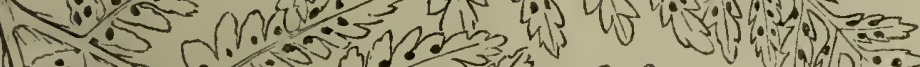

$10.01 \%$

1.40 . N

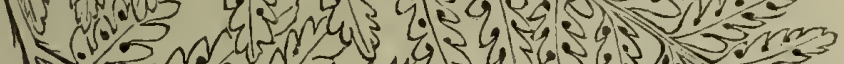

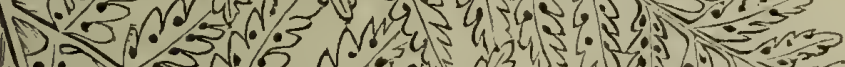

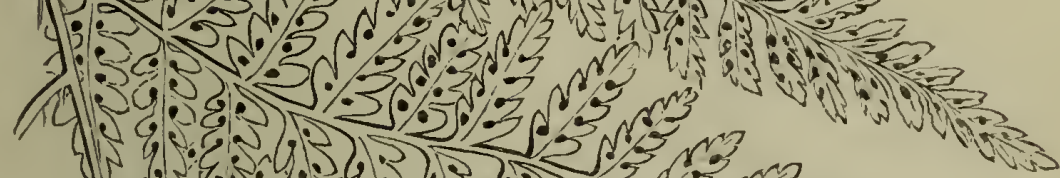

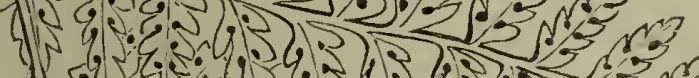

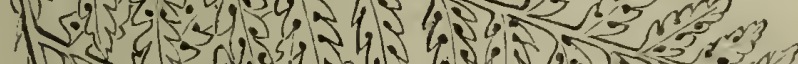

S: 5 s.

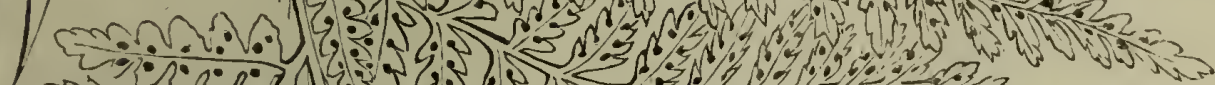

क

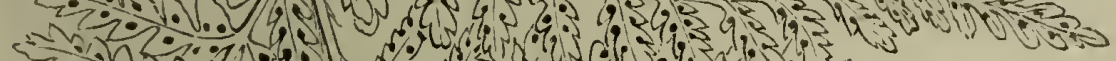

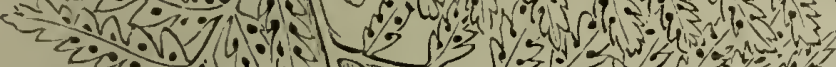

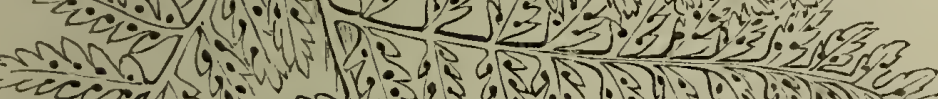

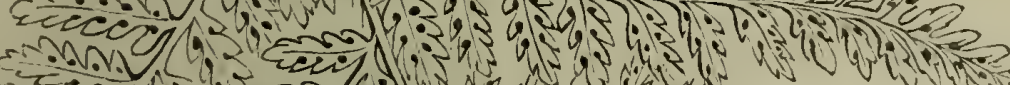

-

हैं

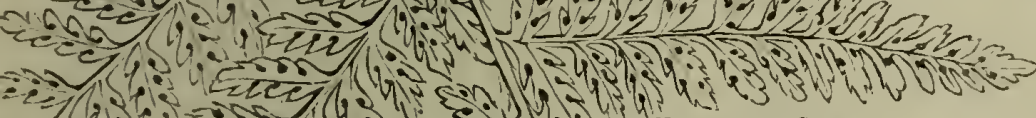

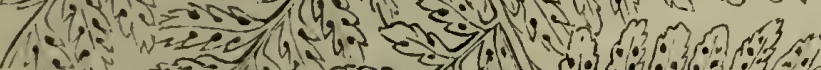

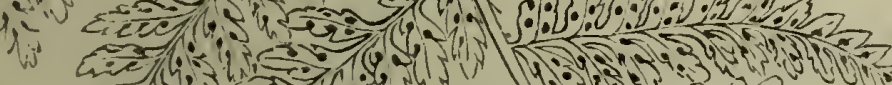

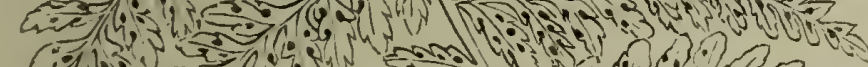

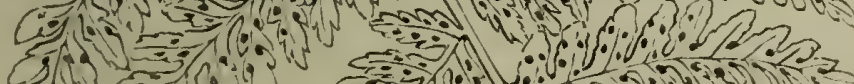

E)

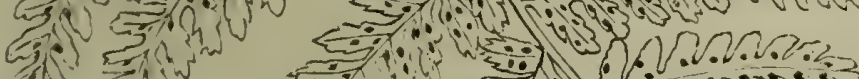

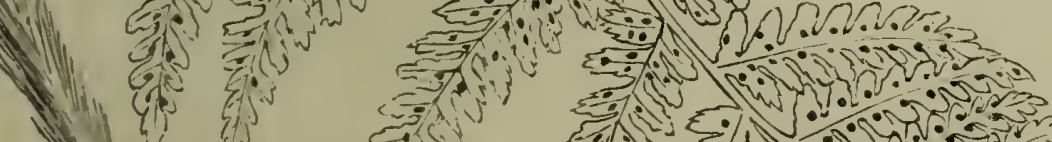

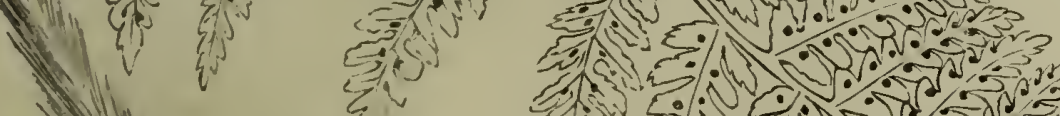

14 in

14 of

i) 4 is as a 

The variety $L$. collina appears to bear so many marks of a distinct species, that we shall quote the whole passage of Mr. Newman's description of it; after stating that the form of the frond varies so greatly between the regular deltoid and the narrow elongate lanceolate, he concludes, the deltoid is the younger fern and the lanceolate the matured, in this the "stem is half as long as the frond, which is elongate lanceolate and pinnate, the pinnæ are very distinct, and set on at nearly right-angles with the main stem; the first pair obtusely deltoid, the second elongate deltoid, and the remainder nearly linear, with acuminate apices; all are pinnate, the pinnæ (secondary pinnules) ovate, obtuse, slightly auriculated, and regularly toothed; their attachment to the mid-stem of the pinnæ resembles that in L. spinosa, there is less appearance of a stalk than in L. multiflora, and the spines of the serratures are far less distinct than in either of these species. All the pinnæ bear seed, but the lower pair less abundantly; the clusters are proportionately larger than in $L$. multiflora: they are crowded, and become confluent, completely hiding the mid-rib of the pinnules. The stem is pale green, with dark brown scales, much resembling in form and colour those of $L$. multiflora. The involucre (indusium) also, as far as I can learn from my specimens, exhibits no discrepancies. Should this fern prove distinct as a species, which I anticipate will be the case when we have more copious materials for forming an opinion, I beg to propose that it be called Lastrace collina, and that it bear the English name of 'Pinder's Fern,' in compliment to the gentleman who first called my attention to its remarkable difference from the usual form of $L$. multiflora, provided always that it proves to be undescribed." Newman's British Ferns, p. 224.

10. L. Fonisecii, (Babbington's Manual, Edition 2.) Nephrodium Fonisecii, (Lowe). (Fig. 1614.) Bree's Fern, or recurved Fern. Stem as long as the frond, purple, hard, and woody, clothed with narrow lanceolate laciniated scales, of an uniform pale brown colour; frond triangular, elongate, curved, scattered over on the under side with sessile glands ; pinnæ pinnate, the lower pair stalked and much larger than the others; pinnules oblong lanceolate, the first lower ones larger than the rest, all distinctly stalked, except towards the point; their lobes (secondary pinnules) oblong, the lower ones stalked, all more or less deeply lobed and serrated with acute teeth, and curved upwards, mid-rein waved, lateral veins alternately branched, terminating before reaching the margin, each anterior branch mostly bearing a circular sorus about the middle of the lateral lobes; indusium an irregular reniform figure, jagged on the margin. 
- L. recurva.-Newman's British Ferns, p. 225. Aspidium dilatatum var. recurvum.-Bree, Mag. Nat. Hist. vol. iv. p. 162.

Roots fibrous, dark brown. Rhizoma tufted, scaly. Frond convolute in vernation, becoming of an elongate triangular form, gracefully curved; pinnate; the lower pinne mostly much larger than the rest, and with a rather long footstalk, the lower ones are lanceo. late deltoid, the middle ones lanceolate, and the upper linear; the upper surface of the frond is a beautiful green paler beneath, and the lobes are turned up, giving the frond a concave, crisped appearance, especially when young, and the whole plant is more or less thickly studded over with small sessile glandular bodies, which emit a peculiar odour by which the plant may be known. The stem is as long as the frond, a dark reddish purple colour, and of a hard almost woody testure; it is thickened at the base, and thickly clothed, especially in luxuriant plants, with thin, brown, uniform coloured membranous scales, of a lanceolate form, cut into two or more slender lobes, giving the stem almost a shaggy appearance. The pinnules are pinnate, and the first lower basal ones are much larger than any of the others, three times as long, or longer, than the opposite ones, this disproportion is very much less in the second pair of pinnæ, and not at all in the rest; the pinnules are oblong, lanceolate, pinnated, all stalked, except a few, at the point; their lobes (secondary pinnules) are deeply cut, and the lower ones on a short footstalk, the rest are attached by their broad base, and one connected to the other by a narrow wing; all are deeply toothed with acute teeth, and all have a tendency to curve upwards, giving the plant a crisped appearance. The mid rib of the lobes is waved, and the lateral veins arise alternately, each going to a tooth but terminating before reaching the margin. The sori are numerous, large, arising from the lateral veins about the middle and from the superior branch, when the lateral vein is divided, and the whole frond is equally covered over with the sori; they are circular and often become confluent, of a yellowish-brown colour. The indusium at first is a leaden colour, becoming pale, reniform, smooth, or scattered over with sessile glands, and jagged in in a very irregular manner on the margin, soon becoming curled up into a shapeless form as the thecæ are developed. Thece rather large, globose, numerous. Sporules minute.

Habitat.-Warm, sheltered woods, and amongst grass, in exposed rocky situations; frequent in Ireland; probably not unfrequent in England; banks of Loch Lomond, Scotland. 
Perennial ; in perfection in August.

Much doubt has been expressed amongst botanists as to this being more than a variety of $L$. multiflora; but its characters, so ably pointed out by Mr. Newman, appear decisive as to its being a aistinct species. It is true there are numerous varieties found which seem intermediate and to connect in an intimate series, L. spinosa, maculata, multiflora, and Fonisecii; but when full grown plants, in a mature state, are taken and compared one with the other, all doubt in favour of their being one and the same species seems to vanish.

Our plate (fig. 1614) represents a common frond but selected smaller than it mostly grows in order to give its natural size rather than a reduced one, and more clearly show its proportions and form; the detached pinnule is represented rather larger than natural to show its lateral veins, the curled up manner of its growth, and the position of the sori; the indusium is also magnified to show its shape and jagged margin. A scale is drawn, detached, and magnified, and shows the manner in which they are lacerated; some, however, are not so much torn as this, and others are entire.

\section{GENUS XVI. TRICHOMANES.-Linn. Bristle Fern.}

Gen. Char. Theca within a marginal, cylindrical, or suburceolate monophyllous receptacle, which is of the same texture as the frond, opening above, and furnished with an exserted bristle,

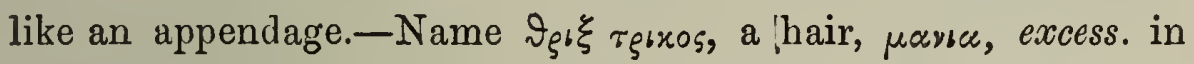
allusion to the hair-like exserted appendage to the receptacle.

1. T. radicaus, (Sw.) (Fig. 1615.) Bristleffern. Frond triangular, lanceolate, pinnate; the pinnæ alternate lobed, and cut into narrow linear, obtuse, entire or bifd segments; receptacle cylindrical, obtuse in the axis of the upper pinnæ; the mouth scarcely two-lipped, containing the thecæ, and attached round the central vein, which projects beyond the receptacle in the form of a bristle.

T. speciosum.-Newman's British Ferns, p. 305.-Brevisetum.Brown, English Flora, vol. iv. p. 311.-Hooker, British Flora, ed. 4. vol. i. p. 390.-T. pyxidiferum. Huds-Hymenophyllum alatum. Finglish Botany, t. 1417. 
ß. Andrewsii, Newman. Frond more elongated; the lower pinnæ distant, short; receptacle with a projecting bristle, very long.

Newman's British Ferns, p. 315.

Roots fibrous, branched, and woolly. Rhizoma round, long, creeping, often several feet long, branched, and adhering to the surface of the rock, or rooting amongst moss, clothed with a thick coating of short, bristly hairs, which, when highly magnified, are seen (as in fig. a) beaded with short, jointed, compressed cells; this pubescence, which takes the place of scales as in other ferns, is confined to the rhizoma of old plants, but it is scattered upon the stems of the young fronds, and falls away as they advance to maturity. The frond is circinate in vernation, and is three years before it attains maturity; is of a triangular lanceolate form, with the lower pinnæ larger and longer than any of the others; but in the variety $\beta$. Andrewsii, it is a more lanceolate form, and the lower pinnæ are smaller, shorter, than the others; it is of a dark green colour, smouth, and shining, and when seen with a magnifying power, between the eye and the light, shews a beautiful reticulated texture, formed by small transparent cells; in the variety $\beta$. the colour of the frond is a beautiful green, not dark green, as is the general colour of the plant. The pinne are pinnate, triangular lanceolate or lanceolate alternate, and connected one to the other by a broadish wing, which wing also extends on each side of the stem to the rhizoma. The pinnules are lobed and deeply cut into narrow, linear, obtuse, or notched segments. The mid-rib and veins are all stout and promiminent, ramifying into each segment, and terminating before reaching the margin. The fructification are cylindrical, suburceolate receptacles, formed of one piece, with a smooth, even lip, mostly notched on one side; and arising in the axis of the pinnules, and tbrough the centre of this receptacle passes the vein, which extends beyond the mouth of it two, three, and four times its length, in the form of a bristle, bearing around its base the theca, which are globose, encircled with an elastic beaded ring.

Habitat.-Wet rocks and caves, Ireland; rare, Turk Waterfall, near Killarney, and various other places in the county of Kerry; in Glendine, and other places, near Youghal ; $\beta$. in a cave, Glanin Caragh.

Perrennial; in perfection in August.

Our illustration of this plant (fig. 1615) is drawn the natural size, and shows the form and mode of developement of the young fronds, and size of the rhizoma, clothed with its remarkable hair-like scales, 

which are represented magnified in the accompanying illustration (fig. $a$ ); and a porion of one of the pinnules magnified (fig. $b$ ), to show the form of the lobes and the position of the fruit in the

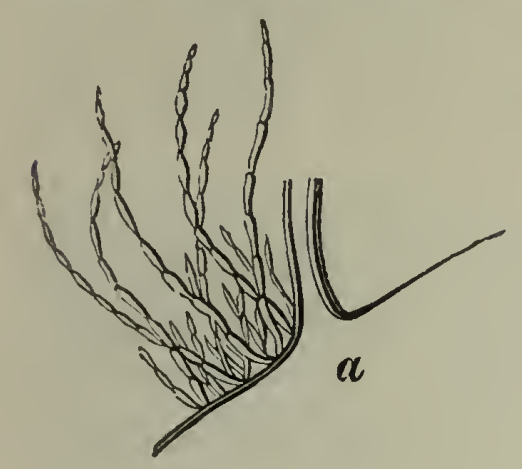
axis, and the mode and distribution of the lateral veins, terminating before reaching the margin. The mode, how. ever, of the attachment of the fruit is very variable, which we have shown $\mathrm{n}$ the figures $c, d, e, f, g$; the fig. $c$ is an usual form, with a short footstalk; in fig. $d$, the footstalk is scarsely observable; (fig. e) the margin of the frond arises high up on the receptacle; (fig. $f$ ) the frond almost reaches the top of the receptacle, and in (fig. $g$ ) it is quite emersed in it ; in these variations, the bristle is also of variable length, from double to three and four times that of the receptacle. We have observed a similar variation in the receptacle bcing encased, as it were, in the frond, in Hymenophyllum tunbridgense, which we have represented under that species; but as the variation is not constant, and there not being other distinctions to mark it as separate from the usual form of the species, we have not considered it a character of any value. The variety $\beta$. Andrewsii, has, by some botanists, been thought a distinct species: its frond is lanceolate; and as well as the stem, much longer than the

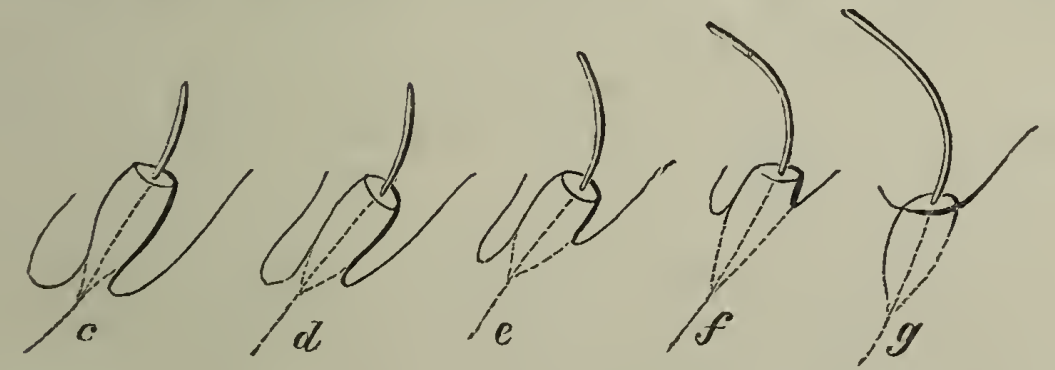

usual form of the plant, and the lower pinnæ are shorter than the others instead of being longer; the lobes of the pinnules are broader and more decurrent; its receptacles emersed in the frond, and its 
bristles more curved and longer, as represented in figures $d, e, f, g$, in the accompanying sketches; but whether these differences are not produced by the situation in which the plant grows, and where it is developed to a greater perfection, seems still doubtful; the subject has been ably and fully treated by Mr. Newman, who still retains it as a variety.

This very remarkable and rare fern is, perhaps, one of our most interesting, as being a connecting link between the sea-weeds and ferns, both from its habit and structure, and still reminds the examiner of the structure of some of our large mosses; but the following species, it will be seen, partake even more of the habit and character of mosses than this; they all, however, open to the student a wide field for research and comparison, for in these little ferns he will find that the thecæ within their cup-like receptacle, are formed as those of the true ferns, with an elastic beaded ring; notwithstanding the receptacle has the form and appearance of the cup of a moss, but its mode of attachment to the frond is that of a seaweed. The structure of the frond is cellular, and as readily absorbs moisture as do the mosses and many algæ; these are points only from which the student may start in a research, and each step in the investigation will furnish him with abundant matter of interest; leading him on in the enquiry with a degree of pleasure, which a study of the objects of nature and truth never fails to stimulate and reward.

GENUS XVII. HYMENOPHYLLUM.-Sмith. Filmy Fern.

Gen, Char. Thece within a marginal two valved receptacle, which is of the same texture as the frond, opening above, not furnished with an exserted bristle-like appendage.-Name, from $\dot{\mu} \mu \eta v, a$ membrane, and $\varphi$ $u \lambda$ ㅇ, a leaf, in allusion to the membranous texture of the frond.

1. H. Tunbridgen'se, Smith. (Fig. 1616.) Tunbridge Filmy Fern. Fronds tender, pinnate, erect, pinnæ erect or spreading, pinnatifid. The segments linear, strongly toothed on the margin, the lateral veins terminating before reaching the margin; receptacle suborbicular, compressed, toothed on the margin ; axillary; rachis strongly winged. 
English Botany, t. 162. - English Flora, vol. iv. p. 313. Hooker, British Flora, ed. 4. vol. i. p. 390. - Newman's British Ferns, p. 321.

Roots black, slender, fibrous. Rhizoma long, slender, black, wiry, branched, and spreading. Frond erect, from one to three inches high, of a delicate tender structure; bright olive green. The stem slender, wiry; about as long as the frond, and bearing generally at its base a few short, slender, dark brown or black rigid hairs, which, when magnified, are seen to be formed of joints. The rachis with a rather broad membranous wing on each side. The pinna alternate pinnate, the pinnules often arising only from one side of the mid-rib of the pinnæ; a simple linear segment, or two or three branched, of a delicate texture, finely reticulated; the margin coarsely serrated. The lateral veins are stout, and terminate before reaching the margin. All the pinnæ are erect, or somewhat spreading. The receptacles are nearly orbicular; flat, from the sides being compressed; two valved, the margins more or less deeply and unequally toothed; the central vein, around which the thecæ are attached, is short, not reaching beyond the middle of the valves; the receptacles are usually in the axis of the pinnæ, but occasionally they are found in the axis of the pinnules, so that each pinnæ bears two and three receptacles. Theca globose, not very numerous, with an elastic beaded ring. Sporules orbicular, roughish.

Habitat.-Moist rocks and stones; amongst moss in moist, mountainous situations, in various counties of England, Wales, and Ireland; banks of the Clyde, Loch Long, and Loch Lomond, Scotland.

Perennial; in perfection in July.

This beautiful little fern not unfrequently grows with the following species, and often so matted and entangled together as to be with difficulty separated one from the other, and they, growing upon moist rocks and stones amongst moss, are often overlooked, from the great resemblance they have to the moss itself. The characters by which they are distinguished as species are sufficiently obvious in the difference of form and structure of the receptacles, as well as in the erect growth of this species and the more compact cellular structure of the frond. The illustration of this fern (fig. 1616.) is made the natural size of an ordinary grown specimen; they are occasionally found larger and often smaller. The detached pinna shows the receptacle as it usually grows; and in the marginal 
illustration (figs. $a, b, c$ ) are shown others, as they are occasionally found, with the frond attached to its sides half way, and even to

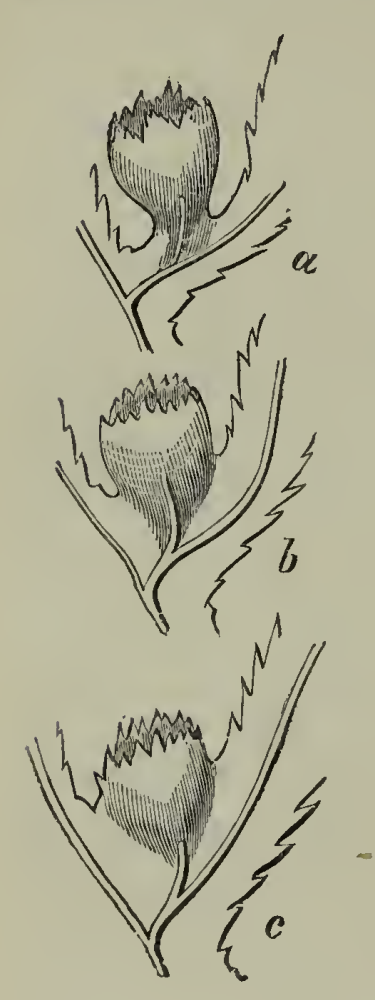
its margin; but, beyond this variation, we have not observed any difference: they are all drawn larger than natural to show their structure more clearly. (Fig. d) shows the jointed, hair-like scales at the base of the stem magnified; from which will be seen the close affinity they bear to those on the rhizomas of Trichomanes radicans, (fig. a page 121).

2. H. Wilsoni, Hooker. (Fig. 1617.) Wilson's Filmy Fern. Fronds rigid, pinnate, drooping; pinnæ spreading or recurved pinnatifid; the segments linear, entire, or slightly toothed on the margin, the lateral veins terminating in the margin; receptacle ovate, inflated, its valves spreading, entire on the margin; axillary, rachis slightly winged to. wards the top.

English Botany Supplement, t. 2686.-

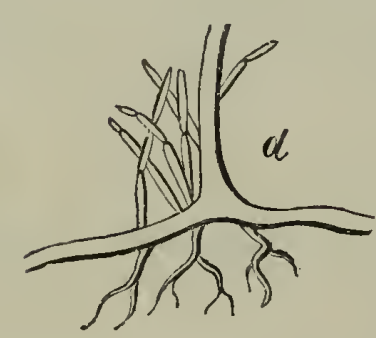
Hooker, British Flora; ed. 4, vol. i. p. 390.Newman's British Ferns p. 325.

Roots black, slender, branched, fibrous, and as well as the Rhizoma similar to the last species, having also a few hair-like scales at its base, and often one or two upon the stem, which is slender, wiry, erect. The rachis is naked, except towards the top; it has a narrow wing on each side. The pinnce are more rigid than the last species, of a darker green colour; its structure, when magnified, is seen to be formed of larger cells, and more strongly reticulated; erect, or spreading, becoming drooping. The pinnules are narrower and generally less strongly serrated on the margin. The lateral veins terminate in the margin. The receptacles are stalked in the axis of the pinnæ, ovate, inflated, the valves entire on the margin and spreading at the mouth. The central vein, around the base of which the theræ are attached, never reaches the margin. The thece are few, globose, with an elastic beaded ring. The sporules orbicular, roughish.

Habitat.-Moist rocks and stones, especially in the north of England, Wales, and Scotland; and in many parts of Ireland. 


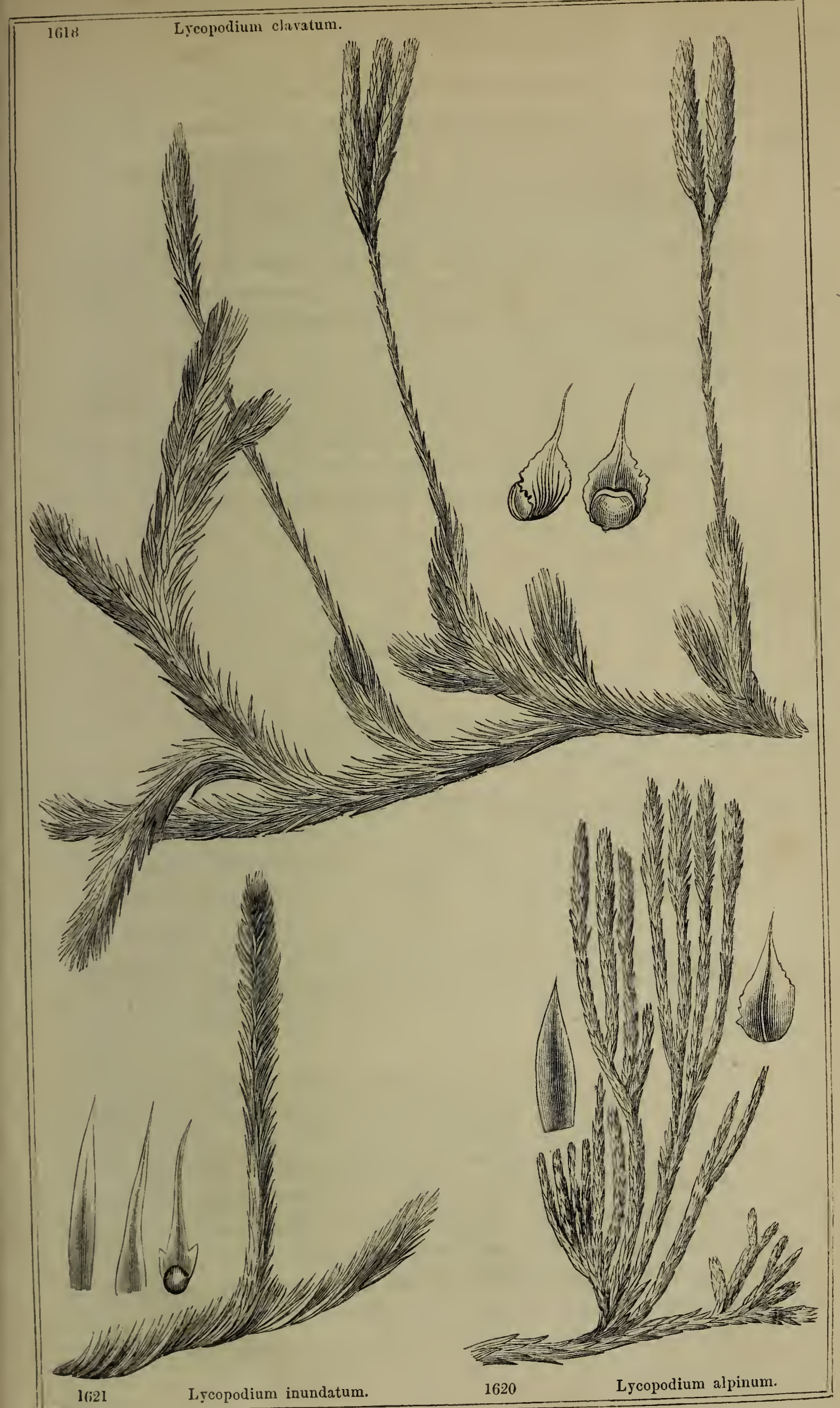



Perennial ; in perfection in July.

This is a much more frequent plant than the last species, often growing in considerable patches, covering the rocks and stones, and spreading itself amongst the moss in entangled masses, and, as already observed, growing: with the last species.

Our illustration of this species is drawn the natural size, the right hand figure showing a luxuriant but barren frond; and the other, a mature fruit-bearing frond; and the detached pinna is magnified to show the structure and position of the receptacle. Frequently more luxuriant and larger specimens than here represented are found, when the pinnæ, instead of bearing only one receptacle, bear two or three; and the frond is then more drooping.

\section{SUB-ORDER I.}

\section{LYCOPODIACEE.}

\section{GENUS I. LYCOPODIUM.-Linn. Club-moss.}

Gen. Char. Theca one celled, two valved, containing a fine pow dery matter; and others three valved, containing a few large sporules. - Name from $\lambda u x \circ s$, a wolf, and $\pi \circ u s, \pi c \delta \circ s$, a foot, which the branches of some of the species are supposed to resemble.

1. L. clava'tum, Linn. (Fig. 1618.) Common Club-moss. Spikes one to three, on an elongated scaly peduncle, their bracts ovate, acuminate, the margins eroso dendate; stem very long, creeping, with ascending branches; leaves small, lanceolate, with a long hair-like point.

English Botany, t. 224.-English Flora, vol. iv. p. 318.-Hooker, British Flora, ed. 4, vol. i. p. 39,-Newman's British Ferns, p. 353.

Roots white, tough, and fibrous, scattered at unequal intervals along the stem. Stem procumbent, creeping, several feet long, branched, very hard, solid, vascular, tough, and rigid; the branches arise alternately, ascending, and are simple or branched, and, as well as the stem, thickly ciothed with imbricated leaves of a yellowish green colour. Leaves narrow, lanceolate, terminating in a long, bristly point; very numerous, crowded, and arising from the stem and branches in a regular spiral order; they are smooth on the margin, 
or slightly toothed, persistent. Inflorescence cylindrical, spike-like, catkins one, two, or three on the top of a rather slender peduncle, bearing shorter, smaller leaves, with erosed margins, and arrayed in a spiral manner; each spike is on a short pedicel, and about an inch long, erect in fruit, becoming afterwards curved; its bracts are crowded, of a pale yellow colour, and a triangular ovate, acuminate, pointed figure, having the margins erosed and membranous, each bearing at its base a sub-reniform theca, of a pale yellow colour, bursting by two valves, and containing numerous very minute sporules of a pale sulphur colour.

Habitat.-Heathy places, in mountainous countries ; common.

Perennial; in fruit in July and August.

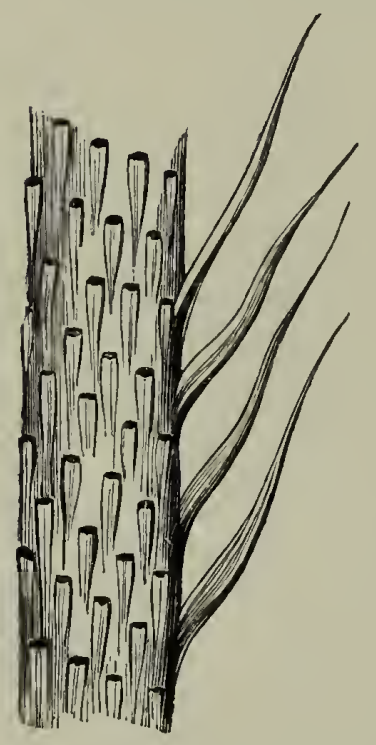

The long cord-like stems of this lycopodium often extend over a space of two or three yards, and form a complete mat upon the surface of the ground, in heathy districts; having by no means an unornamental appearance with their horn-like spikes elevating themselves upon the stalks of a pale yellow colour. When the leaves are stripped off the stem, it will be seen as represented in the marginal illustration, that they leave scars which are arranged in a regular spiral man. ner, and will remind those who have been in the habit of examining the fossil remains of plants, of some of the impressions frequently found on the casts of stems, sometimes as thick as the body of a man, showing to what a magnitude the antidiluvian species attained in comparison with our now slender forms.

The sporules which the thecæ produce in such abundance are collected and sold in the shops under the name of vegetable sulphur, and are said, together with the stems, to be used for the purpose of ameliorating wine; it is used, also, as an absorbing powder to prevent excoriation in children; but the chief purpose to which it is applied is in making of fireworks, on account of its highly inflammable nature; and on the stage, it has been used to produce artificial lightning; but powdered resin answers the latter purpose and is a much cheaper article.

The whole plant of this, as well as some of the other species is used in the formation of various dye colours, and to fix them, instead 
of alum. A decoction of it is said, by the Poles, to be the most successful remedy yet tried in the cure of that dreadful disease of the hair, the Plica polonica. The long slender stems, with their pale coloured spikes, are formed into many pretty ornaments for decorating the houses of country people, and for filling their fire grates during the summer months; for this purpose, it is often sold in the markets under the name of Staghorn-moss.

2. L. annotinum, Linn. (Fig. 1619.) Interrupted Club-moss. Spike solitary, sessile, on the end of the branches; their bracts broadly ovate, cuspidate, with eroso-dendate margins; stem creeping, with erect or ascending branches; leaves linear, lanceolate, acuminate, with a bristle point, and toothed margins.

English Botany, t. 1727. -English Flora, vol. iv. p. 321.-Hooker, British Flora, ed. 4. vol. i. p 391.-Newman's British Ferns, p. 353.

Roots tough and wiry, Stem creeping, slender, tough, and wiry; deeply striated; irregularly branched, at unequal distances, with erect, simple, or divided branches, the increase of which in length with each year is marked by the close-pressed and shorter leaves in the upper part of each portion; the branches are erect, and the fruitbearing ones terminate in a linear, cylindrical, sessile spike. Leaves persistent, linear, lanceolate, sessile, arranged in a spiral order; the margins more or less regularly toothed with sharp teeth; the apex acuminated, terminating in a bristle; the mid-rib stout, prominent at the back. The lower leaves of each annual portion are larger and more spreading than those in the upper: all are hard and rigid, and of a yellowish green colour. Inflorescence a terminal spike; solitary sessile, about an inch long, cylindrical, pale, composed of numerous closely imbricated scales, roundish, ovate, with an acuminated point at the terminus of the mid-rib; the sides are membranous and the margins eroded: each bract bears in its axis a large reniform theca, which contains numerous minute sulphur coloured sporules, which escape from a transverse opening when the theca is ripe.

Habitat.-Wild, mountainous districts; on the side of Glyder Mountain, above Llyn-y-Cwn, North Wales; mountains of Westmoreland and Scotland; not common.

Perennial ; in perfection in August.

This is a well marked and distinct species, remarkable from the manner in which it shows its annual increase of growth, and from this peculiarity it derives its specific name of annotinum; it does 
not appear to be anywhere a very common plant, but is readily distinguished from all our other species.

3. L. alpinum, Linn. (Fig. 1620.) Savin leaved Club-moss. Spike solitary, sessile, on the end of the branches; the bracts ovate, acuminate, toothed on the margin; stem creeping, with erect, repeated dichotomous branches; leaves lanceolate, acute, entire, imbricated in four rows.

English Botany, t. 234,-English Flora, vol. iv. p. 321.-Hooker, British Flora, ed. 4. vol. i. p. 392.-Newman's British Ferns, p. 365.

Roots tough, wiry, branched. Stem creeping, round, tongh, branched, and more or less closely set with leaves, arranged in a spiral manner; the branches numerous, arising at irregular distances, erect, and repeatedly branched in a dichotomous manner, thus forming close, thick, fasciculated masses, from two to four or six inches high, of a bright green colour. Leaves lanceolate, acute, sessile, smooth, shining, of a somewhat leathery texture, rounded at the back, concave in front, and one imbricated over the other in lines, giving the branches a squarish form, the margins are smooth, and the point is not bristly but rather obtuse. The fasicles of the branches all grow to near the same height, and the fruit-bearing ones are terminated in a close cylindrical spike, about half an inch long, of a pale yellowish green colour, sessile. The bracts are ovate, with an acuminated point, the margins membranous and toothed, each bearing in its axis a theca of a kidney-shaped form and yellow colour, containing numerous pale yellow sporules, very minute : after the escape of the sporules the bracts are reflexed, as well as the spikes, which become a dark brown colour.

Habitat.-Elevated mountainous districts, Yorkshire, Derbyshire, Lancashire, and the north of England; common in Scotland and Wales; less frequent in Ireland.

Perennial ; in perfection in August.

This pretty little evergreen plant forms thick spreading patches of its fasiculated branches in the wild mountainous districts, and has much the aspect of a miniature Savin plant, from whence it derives its name; it has a bitter aromatic taste, and if taken in any quantity acts as an emetic, but is not applied to any medicinal uses. It is used in Iceland, according to Sir W. J. Hooker, to dye wnollen cloths; he says that "A vast heap of Lycopodium alpinuri lying before the priest's house, drew my attention, and on enquiry I found that it was used for the purpose of giving their wadmal a yellowish 


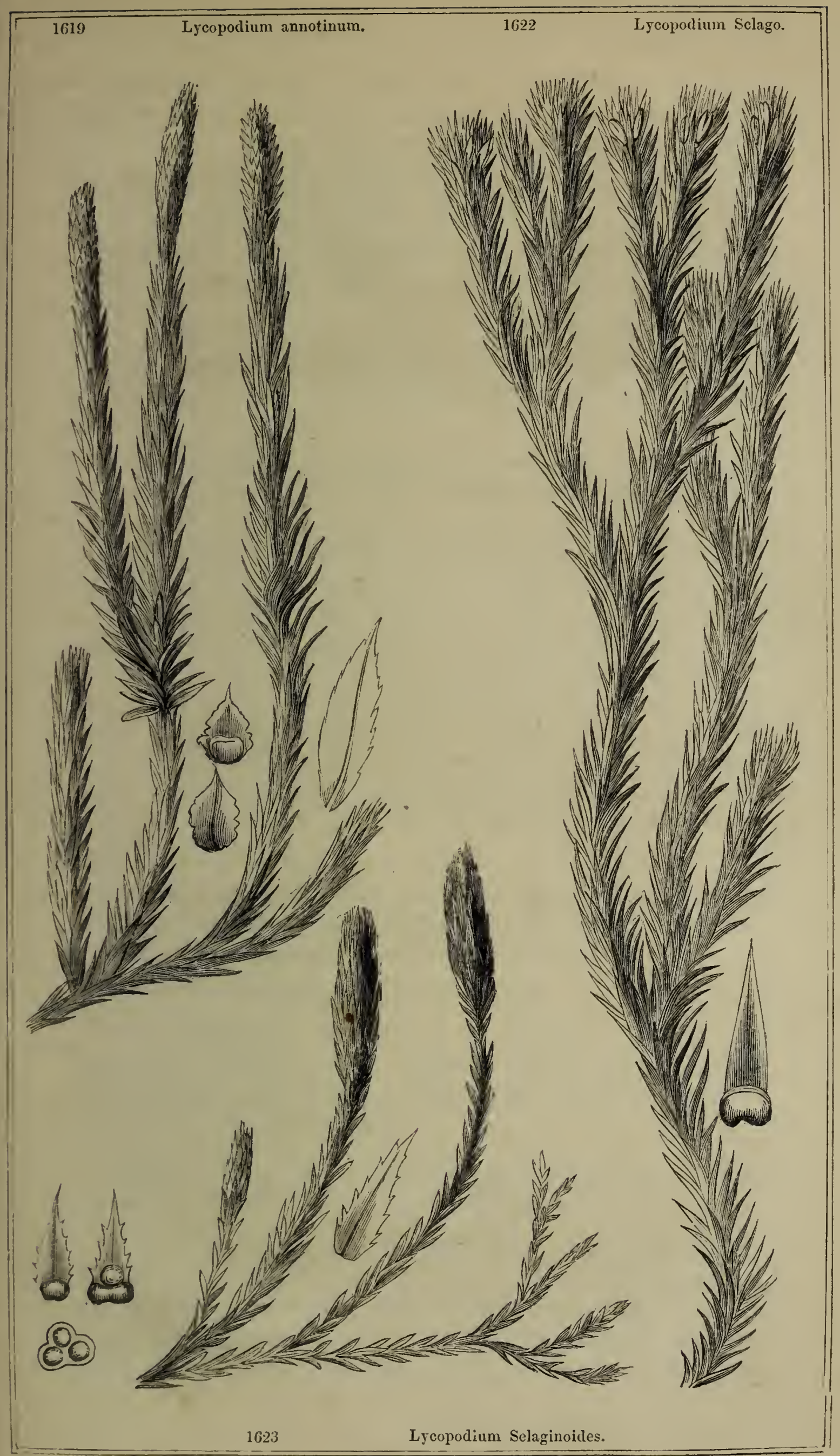




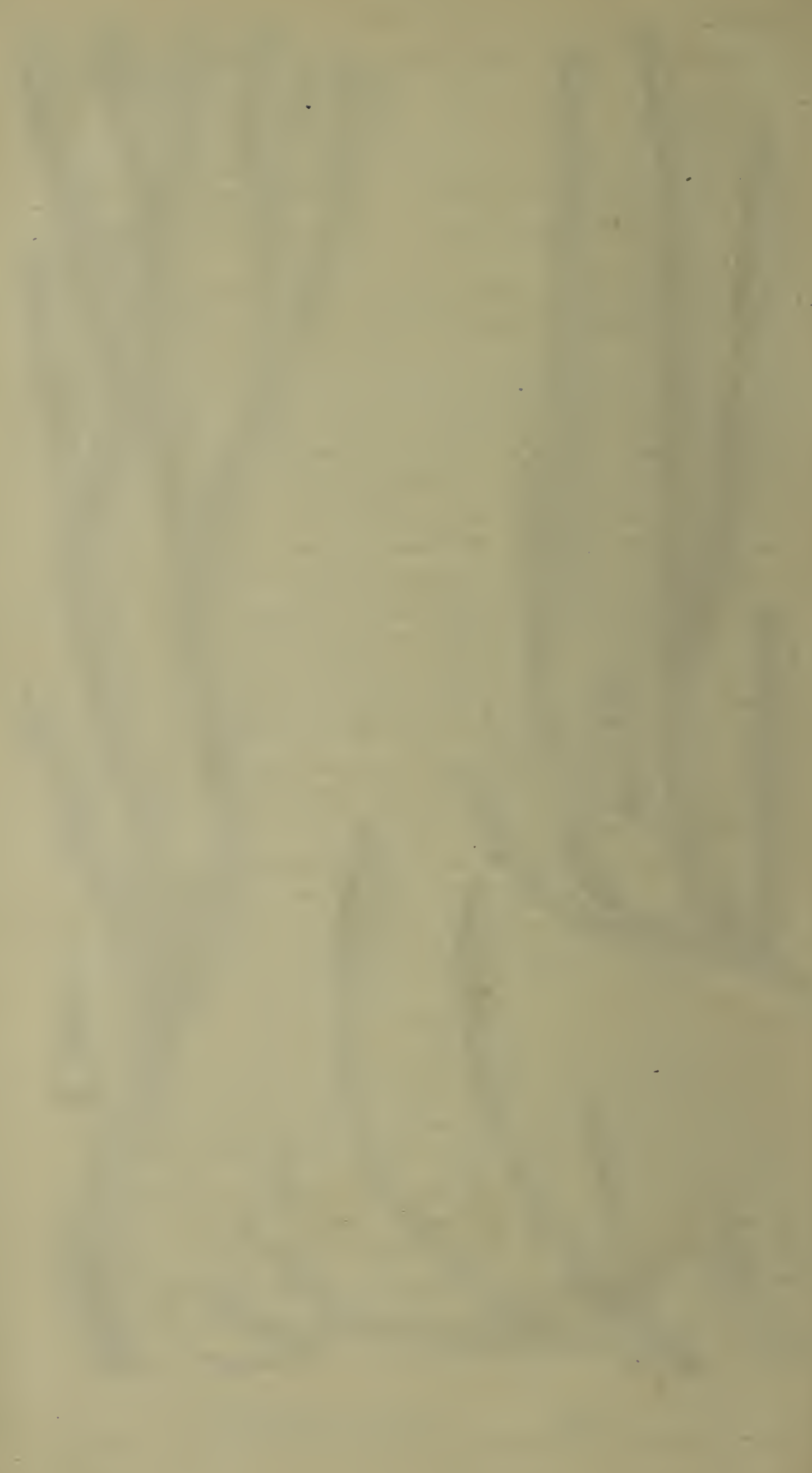


dye, which is done by meiely boiling the cloth in water, with a quantity of the Lycopodium and some of the leaves of Vaccinium uliginosum. The colour imparted by this process, to judge from some cloth shown me, was a pale, pleasant, though not a brilliant yellow." -Journal of a Tour in Iceland in the year 1809, vol. i. p. 214.

4. L. innundatum, Linn. (Fig. 162 L.) MIarsh Club-moss, Spike solitary, terminal; the bracts leafy; stem short, simple, creeping; branches, erect, simple, terminating in a spike ; leaves narrow, linear, lanceolate, acute, entire.

English Botany, t. 239.-English Flora, vol. iv. p. 319.-Hooker, British Flora, ed. 4, vol. i. p. 391. Newman's 13ritish Ferns, p. 369.

Roots short, stout, branched Stem from one to four inches long, creeping, simple, very rarely branched, thickly clothed with imbricated leaves. Leaves narrow, linear, lanceolate, entire on the margin, the point acute; those of the stem curved upwards, on the branches; erect. Inflorescence a terminal cylindrical spike, about an inch long and elevated on a footstalk, or branch, about its own length; its bracts are similar to the leaves, except the base being rather broader and sometimes with a single tooth on each side, each bract bearing in its axis an almost spherical theca, of a pale yellowish green colour, containing numerous minute pale yellow sporules.

Habitat.-Moist heaths and commons; frequent in the south of England; less common in the Midland and Northern Counties; and rare in Wales and Scotland: not known in Ireland.

Perennial; in perfection in July and August.

5. L Selago, Linn. (Fig. 1622) Fir Club-moss. Leaves linear, lanceolate, acuminate, entire; coriaceous rigid, crowded, the upper ones bearing in their axis the thecæ; stem ascending, branched, with dichotomous erect branches.

English Botany, t. 233.-English Flora, vol. iv. p. 320.-Hooker, British Flora, ed. 4, vol. i. p. 392.-Newman's British Ferns, p. 375.

Roots numerous, tough, wiry, branched. Stem short, procumbent at the base, ascending or erect, and branched two, three, and four times in a dichotomous manner, round, hard, tough, from three to six and sometimes eight inches high, thickly clothed with imbricated leaves, of a yellowish green colour, smooth, linear lanceolate 
or lanceolate with an acuminated point; the margins smooth, of a rigid, leathery texture, more rigid, shorter, and close pressed to the stem of those plants grown in a dry, exposed situation; longer, less rigid, and spreading in plants grown in more humid places. Theca rather large, reniform, sessile in the axes of the leaves, especially in the upper ones, yellow, two valved, containing nu. merous minute pale yellow sporules. Besides the thecæ and sporules, or seeds by which the plant is propagated, the leaves in various parts of the branches, but especially at the top, become transformed into buds, which separate and fall to the ground, put out roots, and expand into plants. These buds are formed by a leaf which becomes shorter and swollen on the outside, at the base; and from its inner margin it puts out five smaller lanceolate teeth (fig. 1, 2) $a, b$,) elevated on a short, hardened footstalk; within this is a whorl of three ovate oblong acute leaves, with two scales at the base, one at the back of one, and the other between two of the leaves (fig. $1,2,3, c, d, e$ ) ; and within this whorl is a close, thick, oblong process, which elongates and puts out small leaflets, and expands into a plant.
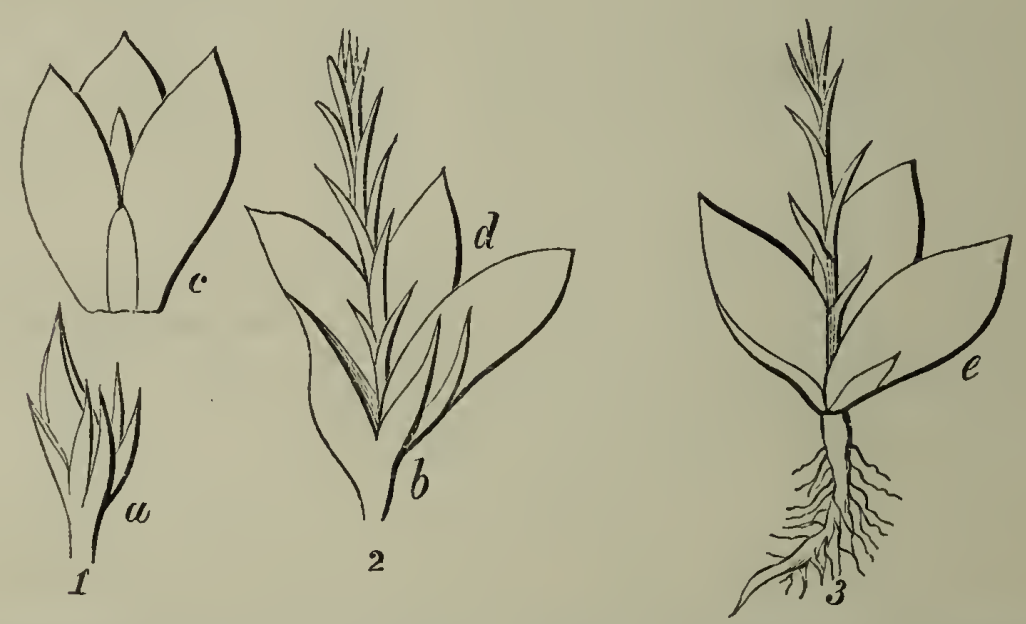

Habitat.-Heathy and stony places, especially in mountainous countries ; common.

Perennial ; in perfection in August.

Our figure, 1622, representing this plant is drawn the full size and shows amongst the upper leaves some which are transformed into buds; and detached is shown a magnified leaf with its theca attached to its base, while the above figures represent the detached buds drawn much larger than they are in a natural state. Fig. 1 shows in the lower part $a$ the swollen six lobed leaf, which is analagous to the calyx of flowering plants; $c$ is the inner whorl, 
elevated from within the calyx to show more distinctly its form, and that it is composed of three large pieces and two small scales; one as there shown-between the larger ones, and the other is opposite to it; and at the back of the third, large pieces, as seen in (fig. 3.) This whorl might be called the corolla, as in flowering plants; within it, in the centre, is an elongated process, short, and unex, panded in fig. $1, c$; but more developed, and putting out its leaves in fig. 1.2. It is not unfrequent to find these buds attached to the parent plant, with the central process as much expanded as represented in fig. 2 ; but as the whorl $c$ and $d$ readily separates from its base by slight causes, they commonly detach themselves, fall to the ground, and put out from their base a prolongation, with numerous minute filaments, which form into roots, attach themselves to the ground, and expand. The inner process puts out its leaves in a spiral arrangement and expands into a plant, as seen in fig. 3. This beautiful and remarkable process in the economy of the plant is one of great interest, and may readily be observed in its native place of growth, or in plants grown under glasses.

This species was at one time farnous for its medicinal powers in the cure of diseases of the eyes; and, according to De Thiers, received its name from the Celtic sel, sight; and jach, salutary. It possesses powerful irritating properties; and in the Highlands of Scotland is said to be still made into an ointment which is used as a counter irritant in parts near to the eyes for the cure of diseases in those organs, but is much too violent in its action to apply to the eyes themselves; it is used, however, as an application to foul, indolent ulcers, and might be used for the purpose of keeping up a discharge from blisters in the place of savin ointment; notwithstanding the powerful irritating properties which it possesses, it is said to be administered by the Highlanders in the form of an infusion as an emetic and carthartic; but much care is required in its administration, for if too large a dose is given it causes giddiness and convulsions. In Sweden, according to Linnæus, the decoction of this plant is used as an external application to destroy vermin upon cattle; and, doubtless, from its properties, is an effectual remedy and might be used with advantage, by poor people, for the same purpose. The Highlanders use it in the process of dying some of their colours to fix them in the place of alum.

6. L. selaginoides, Linn. (Fig. 1623.) Prickly Club-moss. Spike terminal, solitary, sessile, leafy ; stem creeping, with short, ascending 
branches; leaves scattered, spreading, lanceolate, and serrated with spinous teeth.

English Botany, t. 1148. English Flor', vol. iv. p. 319. Hooker, British Flora, ed. 4. vol. 1. p. 392. Newman's British Ferns, p. 371. Selaginella spinulosa. Alex Brawn ap. Doell.

Roots very slender, fibrous. Stem slender, procumbent, branched, pale, thin, delicate, branches simple, erect or ascending from one to three inches high, terminating in an elongated spike. Leaves lanceolate, of a thin delicate texture, with a slender mid-rib; the margins toothed with slender spreading teeth, like little spines; the leaves of the stem are shorter, more distant, and spreading than those of the branches. Spike terminal, about an inch long; its bracts similar to the leaves, but larger and closer pressed, not spreading, the lower ones bearing in their axis large thece, three-celled, and containing three globose bodies, or four-celled and four grains, each grain with a depression at the base. The upper bracts bear in their axes a subreniform theca, containing minute pulverulent sporules; each theca bursts by two valves, though sometimes the lower ones are said to burst in four directions.

Habitat.-Wet boggy places by the side of mountain rills, \&c., in the north of England, Wales, and Scotland; and Ireland not unfrequently.

Perennial ; in perfection in August.

Our illustration of this curious little plant is drawn the natural size, and a detached leaf shows the spinous serratures of the margin, and one of the detatched bracts the shape of the theca of the upper ones, which contains the pulverulent pollen as in the other species; and the other shows the lower bract, with the theca threecelled, and containing the larger granular bodies, and the lower figure shows the theca separated and the grains within the cells. There has been much speculation arnongst botanists as to the different offices which these different sized grains perform in the reproduction of the species. We are much disposed to think with Wablenberg, that they are only varieties in size, and that both the kinds produce plants equally well; but our observations are not sufficiently matured to justify us in speaking positively as to whether this be really the case or not. 



\section{SUB-ORDER II.}

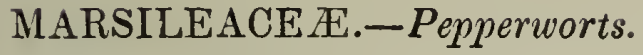

\section{GENUS I. ISOE'TES.-LiNN. Quillwort.}

Gen. Char. Involucres formed by the dilated base of the leaves, and enveloping the theca, some containing a few large and other's numerous small granular sporules. Sporules both rough and angular.

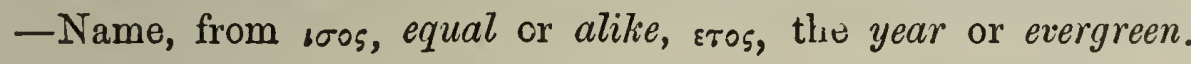

1. I. lacustris, Linn. (Fig. 1624.) European Quillwort. Leaves awl-shaped, bluntly four angled, and with four longitudinal intelnally jointed tubes.

Finglish Botany, t. 1084. English Flora, vol. iv. p. 330. Hooker, British Flora, ed. 4. vol. i. p. 392. Newman's British Ferns, p. 381 .

Roots long semipellueid, simple or branched, towards the extremity tubular. Rhizoma sub-globose, of a dark brown spongy texture, externally white and compact within; and in the centre is a semipellucid portion from which the leaves seem first to arise. Leaves persistent, awl-shaped, from four to six inches long, erect, arising from the crown of the rhizoma, dilated, pale, and sub-membranous at the base, round or bluntly quadrangular above, and of an olive green colour; internally it has four tubes, which pass through its whole length, and these are divided at intervals with transverse partitions or joints, they are very brittle and easily break off at the joints. The young and vigorous leaves are mostly surrounded at the outside, at the base, by the remains of the former leaves, the tops of which have decayed and fallen away. Thece sub-globose, membranous, hard, enveloped in the base of a leaf which forms its involucre; some of these thecæ contain globose bodies marked at the top, with a triangular elevated suture and also with another which encircles it; at these sutures the valves separate; externally they are rough, with minute incrustations, and an opaque white; and within is a sub-globose semi-gelatinous substance; these sporules are said to be attached to several transverse slender placenta. Other thecæ, which 
are similar in shape and substance, and enveloped in the same way in the base of the leaves, contain minute angular sporules, very numerous, of a pale sulphur-yellow colour.

Habitat.-The bottom of mountain lakes; not uncommon.

Perrennial ; in perfection in June.

Besides the erect growing form of the plant as here described, there is another, which has been regarded as a distinct species; it is characterised by having shorter, thicker leaves, which spread around and not in the erect position as is the case in the general form of the mature plants. It would appear, however, that these are only young plants, growing solitary, and not as is usually the case grown in a crowded mass from the developement of the seeds in the bosom of the thecæ, but each escaped and established separate from the crowd.

Our drawing illustrating this species (fig. 1624) is made the natural size of an ordinary plant in its usual state of growth. On the left hand is shown the lower portion of a leaf with a theca attached to it as found growing, except that the membranous sides, which form the involucre, are turned back to show it more clearly; beneath is the theca magnified and cut in half to show the sporules within, and by its sides is one of the sporules more magnified to show its granular covered coat and the sutures where it opens; and next to this is the sporule, opєn by the separtion of its three valves, and exhibiting the semi-gelatinous globose mass within. On the right hand is shown also the lower portion of a leaf and a theca in the natural position; and beneath is the theca divided in half to show the arrangement of the minute granular bodies, with which it is filled; and by the side of it some of these angular grains magnified with a higher power to show their form.

It is still a subject for investigation as to what these different bodies are, and the office which they perform in the economy of the plant; and it is hoped that as there is now so much more attention paid to the cultivation of ferns, that some one will turn his enquiries to these very curious, humble denisons of our lakes, especially as they may be, as asserted by Kay, grown in fish ponds; and we do not think there would be much difficulty in growing them in glass cases, where their propagation and developement could be more minutely observed. 


\section{GENUS II. PILULARIA.-Linn. Pillwort.}

Gen. Char. Thece naked, axillary, containing in the upper part sessile corpuscles, which emit a yellow pollen or dust; and below these are other sessile bodies, which become single grained fruit.-Name, from pillula, a little pill, in allusion to the form of the fruit.

1. P. globulifera, Linn. (Eig. 1625.) Creeping Pillwort. Leaves setaceous, two to four together; thecæ axillary, hairy.

English Botany, t. 521. English Flora, vol.4. p. 329. Hooker, British Flora, ed. 4. v. 1. p. 392. Newman's British Ferns, p. 393.

Roots from one to four inches long, slender, simple, or slightly branched, hollow, and at various intervals with transverse joints, arising from the rhizoma at the base of the leaves, and are two or three in number. Rhizoma thread-like, cylindrical, smooth, except towards the apex, and the base of the new leaves is clothed with jointed hair-like scales, similar to those on Trichomanes and Hymenophyllum; but these soon fall away and leave the rhizoma quite smooth; it is simple or alternately branched at the junction of the leaves. Leaves curled up in vernation, becoming erect, smooth, bright green, bristle shaped, from one to three inches long, and in clusters of from two to four; hollow. Theca globose, about the size of a small pea, on a short footstalk in the axis of the leaves, thickly clothed with pale brown jointed hairs; when matured the theca opens at the apex and splits into four quarters for the escape of the sporules, each quarter remaining attached to the footstalk, and showing the lower portion to be occupied with large sub-globose bodies, and the upper portion with small granular yellow bodies. The lower bodies have been observed to germinate and become plants; but the specific office of the upper granules is not yet known.

Habitat.-Margins of pools and lakes, and in low places which are occasionally overflowed.

Perennial ; in perfection in July.

The germination of the lower bodies of the theca has been carefully watched during the progress of their developement and described by Mr. Valentine, in the Transactions of the Linnæan 
Society, vol. 18 ; and we hope, as we have said above, that further observations will be made so as to throw some light on the nature of the upper small bodies of the thecæ.

Our illustration (fig. 1625) is drawn the natural size of the plant:
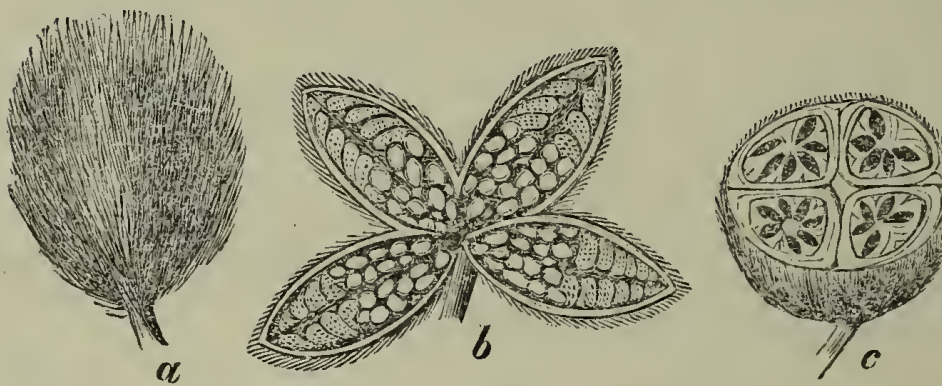

the accompanying figures drawn larger than natural, show in fig. $a$ the entire theca, clothed with its rough coat of jointed

hairs; fig. $b$ is the same burst open into its four quarters, and exhibiting its sporules ready to escape from their cells; fig. $c$ is a transverse section of a theca in its lower part, showing the arrangement of the cells and the sporules within them. 


\section{N D E X}

OF THE

\section{GENERIC AND SPECIFIC NAMES, \&C.,}

IN VOL. IV.

\begin{tabular}{|c|c|c|c|c|c|c|c|}
\hline & & & Page & & & & Fage \\
\hline Acrostichum & .. & - & 74 & septentrionale & e.. & $\cdots$ & 74 \\
\hline ADIANTUM & $\because$ & - & 49 & trichomanes & -. & - & 73 \\
\hline Capillus Vene & eris & .. & 49 & trifidum & . & -. & 58 \\
\hline ALLOSORUS & . & . & 47 & viride & -. & $\cdots$ & 71 \\
\hline crispus & .. & . & 47 & ATHYRIUM CONVE & $\mathbf{E} \mathbf{X} \mathbf{M}$ & -. & 60 \\
\hline Aspidium & .. & $\therefore$ & 91 & dentatum & -. & $\cdots$ & 60 \\
\hline acu'eatum & . & -. & 91 & filix fremina & -. & $\cdots$ & 99 \\
\hline angulare & . & $\cdots$ & 95 & incisum & $\cdots$ & $\cdots$ & 00 \\
\hline cristatum & $\cdots$ & $\cdots$ & 103 & molle & $\cdots$ & $\cdots$ & 39 \\
\hline dentatum & $\cdots$ & $\cdots$ & 85 & ovatum & $\cdots$ & $\cdots$ & 00 \\
\hline depastrum & $\cdots$ & . & 101 & trifidum & $\cdots$ & $\cdots$ & \\
\hline dilitatum & $\cdots$ & $\cdots$ & 113 & & & & \\
\hline dumetorum & $\cdots$ & .. & 113 & Blechum boreale & -. & $\cdots$ & 51 \\
\hline erosum & . & .. & 101 & BOTRYCHIUM & $\cdots$ & $\cdots$ & 34 \\
\hline Filix mas & $\cdots$ & .. & 101 & lunaria & - & .. & 34 \\
\hline irriguum & $\cdots$ & .. & 61 & lunaria minor & ramosa & *. & 3 \\
\hline lobatum & $\cdots$ & .. & 91 & minor foliis $\mathrm{d}$ & lissectis & & 3 \\
\hline lonchitis & $\cdots$ & .. & 89 & racemosa minc & or adiant & ifolia & 35 \\
\hline lonchitidoides & $\cdots$ & .. & 91 & & & & \\
\hline mortanum & $\cdots$ & $\cdots$ & 88 & CETERACH & .. & .. & 8 \\
\hline recurvum & $\cdots$ & . & 118 & officinarum & $\cdots$ & . & 81 \\
\hline rhaticum & $\cdots$ & $\cdots$ & 86 & Cryptogramma cris & spa & . & 48 \\
\hline vigidum & $\cdots$ & $\cdots$ & 100 & Cyathea dentata & $\cdots$ & -. & 85 \\
\hline spinulosum & $\because$ & $\cdots$ & 113 & asthriscifolia & $\cdots$ & $\cdots$ & 86 \\
\hline $\begin{array}{l}\text { PLENIUM } \\
\text { acutum }\end{array}$ & $\ddot{\cdots}$ & $\because$ & 57 & cynapifolia & $\cdots$ & $\cdots$ & \\
\hline $\begin{array}{l}\text { acutum } \\
\text { Adiantum nig }\end{array}$ & rum & $\begin{array}{l}\cdots \\
\ldots\end{array}$ & 66 & incisa & $\cdots$ & $\cdots$ & \\
\hline $\begin{array}{l}\text { Adiantum nig } \\
\text { alternifolium }\end{array}$ & .. & $\ddot{\cdots}$ & 64 & montama & .. & $\cdots$ & \\
\hline & .. & $\cdots$ & 77 & regia & .. & . & \\
\hline $\begin{array}{l}\text { Breynii } \\
\text { Filix fæmina }\end{array}$ & .. & $\ddot{0}$ & 77 & Cysteafragilis & .. & .. & 85 \\
\hline $\begin{array}{l}\text { Filix fæmina } \\
\text { fontanum }\end{array}$ & .. & $\cdots$ & 57 & angustata & .. & .. & 86 \\
\hline fontanum & $\ddot{0}$ & $\cdots$ & 62 & dentata & .. & .. & 85 \\
\hline germanicum & $\ddot{x}$ & - & 77 & Cystopteris & .. & .. & \\
\hline Halleri & $\ddot{x}$ & $\ddot{0}$ & 62 & alpina & . & .. & \\
\hline incisum & $\begin{array}{l}\cdots \\
\cdots\end{array}$ & $\cdots$ & 60 & angustata & - & $\cdots$ & 86 \\
\hline lanceolatum & $\cdots$ & $\begin{array}{l}\cdots \\
\ldots\end{array}$ & 67 & angustifolia & $\cdots$ & $\cdots$ & 80 \\
\hline marinum & $\begin{array}{l}\cdots \\
\cdots\end{array}$ & $\begin{array}{l}\cdots \\
\ldots\end{array}$ & 6 & anthriscifolia & $\cdots$ & -. & \\
\hline molle & $\cdots$ & $\ddot{\cdots}$ & $\begin{array}{l}59 \\
66\end{array}$ & cynapifolia & $\cdots$ & $\cdots$ & 85 \\
\hline $\begin{array}{l}\text { obtusum } \\
\text { officinarum }\end{array}$ & $\ddot{0}$ & $\ddot{0}$ & $\begin{array}{l}66 \\
66\end{array}$ & $\begin{array}{l}\text { dentata } \\
\text { fragilis }\end{array}$ & $\cdots$ & $\because$ & -88 \\
\hline $\begin{array}{l}\text { officinarum } \\
\text { ovatum }\end{array}$ & .. & .. & $\begin{array}{l}66 \\
60\end{array}$ & $\begin{array}{l}\text { fragilis } \\
\text { montana }\end{array}$ & $\cdots$ & $\cdots$ & 88 \\
\hline $\begin{array}{l}\text { ovatum } \\
\text { rhøticun }\end{array}$ & .. & .. & 60 & motrtana & $\cdots$ & -・ & \\
\hline ruta-muraria & $\cdots$ & .. & 75 & EQUISETUM & . & .. & 13 \\
\hline Scolopendrium & $\cdot \cdot$ & -. & 78 & alpinum & $\cdots$ & .. & 23 \\
\hline & & & & & & & \\
\hline
\end{tabular}


INDEX.

arvense
Jrummondii
elongatum
fluviatile
hyemale
limosum
Mackaii
nudum
palustre
polystachion
ramosissimum
ramosum
reptans
scirpioides
sylvaticum
Telmateia
umbrosum
variegatum
Wilsoni

Grammitis Ceterah. .

Gymnogramma .

HYMENOPHYLLUM .

Tunbridgense ..

Wilsoni

ISOETES

lacustris $\quad$.. $\quad \ldots \quad 133$

LOMARIA

spicant

LASTRAA

collina

crispa

cristata

dilatata

erosa

Filix mas

Fœniseci

maculata

multiflora

nana

oreopteris

recurva

rigida

spinosa

spinulosa

Thelypteris

LYCOPODIUM

alpinum

annotinum

clavatum

inundatum

selaginoides

selago

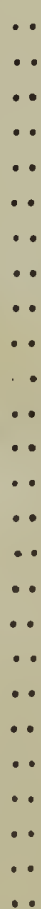

$\cdots$

51

96

$\because \quad 114$

.. 108

.. 107

.. 113

.. 101

.. 103

$\therefore \quad 117$

. 110

$\therefore \quad 113$

$\because \quad 1$ I 4

. 98

.. 118

$\ldots 99$

.. 108

.. 108

$\because \quad 96$

.. $\quad 125$

.. 128

.. 127

$\because \quad 125$

.. 129

.. 131

$\begin{array}{ll}\cdots & 131 \\ \ldots & 129\end{array}$

Nephrodium Fonisecii

$\begin{array}{cccr}\text { Orhioglossum } & \ldots & & \text { Page } \\ \text { vu!gatum } & \ldots & & 33 \\ \text { Osmunda } & \ldots & \ldots & 33 \\ \text { lunaria } & \ldots & \ldots & 36 \\ \text { regalis } & \ldots & \ldots & 34\end{array}$

Polypodum $\quad$. . $\quad$. 37 anthriscifolium $\quad$.. $\quad 86$

$\begin{array}{llll}\text { calcareum } & \text {.. } & \text {.. } & 43\end{array}$

Cambricum .. $\quad$.. $\quad 39$

$\begin{array}{llll}\text { cynapifolium } & . . & & \\ \text { Ca } & 8 & 86\end{array}$

$\begin{array}{llll}\text { dentatum } & \ldots & \ldots & 85\end{array}$

dryopteris $\quad . . \quad$.. 42

fragile $\quad \ldots \quad \quad \ldots \quad 85$

fragraus $\quad . \quad 100$

heliopteris $\quad \ldots \quad$.. 101

hyperb reum .. $\quad$.. 46

lobatum $\quad$.. $\quad$.. $\quad 91$

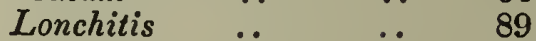

montanum .. $\quad$.. 88

phegopteris .. $\quad$.. $\quad 41$

$\begin{array}{llll}\text { Rhœlicum } & \text {. } & \ldots & 86\end{array}$

$\begin{array}{llll}\text { tenue } & \ldots & \ldots & 86\end{array}$

vulgare $\quad \ldots \quad \ldots \quad 37$

Pilularia $\quad$. . $\quad$.. 135

globulifera $\quad \ldots \quad$.. 135

Polystichum $\quad$. $\quad \ldots \quad 89$

aculeatum $\quad$.. $\quad$.. 91

angulare $\quad \ldots \quad \ldots 95$

lobatum $\quad$.. $\quad$.. 91

lonchitis $\quad . \quad$. 71

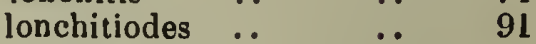

strigosum $\quad \ldots \quad \ldots 00$

$\begin{array}{llll}\text { Pteris } & \ldots & \ldots & 52\end{array}$

aquilina $\quad \ldots \quad \quad \ldots \quad 53$

$\begin{array}{llll}\text { crispa } & \ldots & \ldots & 48\end{array}$

SCOLOPENDRIUM

$\begin{array}{llll}\text { ceterah } & \text {.. } & \text {.. } & 81\end{array}$

$\begin{array}{llll}\text { crispa } & \ldots & \ldots & 81 \\ \text { dredalea } & \ldots & . . & 78\end{array}$

$\begin{array}{llll}\text { dadalea } & \ldots & \ldots & 78\end{array}$

$\begin{array}{llll}\text { lobata } & \ldots & & \\ \text { offcinarum } & & \text {.. } & 78\end{array}$

$\begin{array}{llll}\text { officinarum } & \text {. } & \text {.. } & 78\end{array}$

$\begin{array}{llll}\text { Phyllitis } & \cdots & \cdots & 78\end{array}$

polyschides .. $\quad$.. 78

$\begin{array}{llll}\text { vulgare } & \ldots & \ldots & 78\end{array}$

TKICHOMANES _. $\quad \ldots \quad 119$

Andrewsii $\quad$.. $\quad$.. 120

$\begin{array}{llll}\text { brevisetum } & \ldots & \ldots & 119\end{array}$

pyxidiferum .. $\quad$.. 119

$\begin{array}{llll}\text { radicaus } & \ldots & \ldots & 119\end{array}$

speciosum $\quad$.. $\quad$.. 119

Woodsia $\quad$.. $\quad$.. 45

hyperborea $\quad \ldots \quad$ …

ilvensis $\quad \ldots \quad \ldots 6$ 


\section{N D E X}

OF

\section{ENGLISH NAMES,}

To VOL. IV.

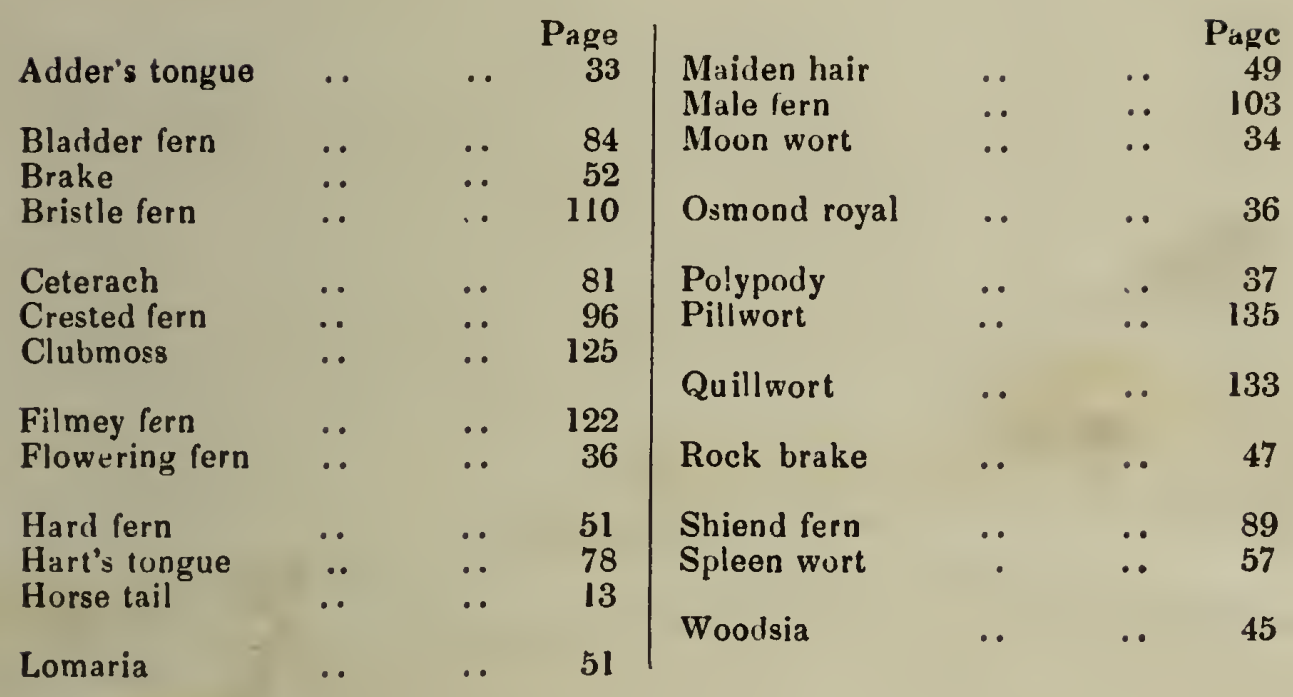






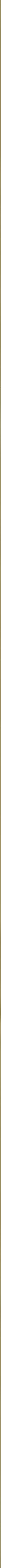



